\title{
Taina Tuori
}

\section{From League of Nations Mandates to Decolonization. \\ A History of the Language of Rights in International Law}

Doctoral dissertation to be presented for public examination, by due permission of the Faculty of Law at the University of Helsinki, in Porthania Hall P674 (Yliopistonkatu 3, $6^{\text {th }}$ floor) on the $9^{\text {th }}$ of December, 2016 at 12 o'clock. 
(C) Taina Tuori 2016

Cover design: Juhana Heikonen

ISBN 978-951-51-2754-9 (paperback)

ISBN 978-951-51-2755-6 (PDF)

Printed in Helsinki, Finland, by Unigrafia Oy, November 2016 


\section{Table of Contents}

Acknowledgements $\quad$ v

1. Introduction 1

1.1 The Research Question 2

$\begin{array}{lr}1.2 \text { Rights Language } & 6\end{array}$

$\begin{array}{ll}1.3 \text { Mandates and International Law } & 17\end{array}$

1.4 Colonies and the Language of Humanitarianism 20

1.5 Earlier Scholarship on the Mandates 25

2. The League of Nations and the Establishment of the Mandates System 31

2.1 Establishing the Mandates 31

2.1.1 Drafting the Mandates System $\quad 31$

2.1.2. The Concept of "Mandate" 43

2.1.3. The Problem of Sovereignty 52

2.1.4. Was the Mandates System Merely a Continuation of Colonization? 59

2.2 The Permanent Mandates Commission and the League Organs 69

3. Themes: A Reading of the Minutes of the Permanent Mandates

Commission

3.1 Introduction $\quad 81$

3.2 Freedom of Religion $\quad 89$

$\begin{array}{lr}3.3 \text { Slavery } & 100 \\ 3.4 . \text { Forced Labour } & 111\end{array}$

3.4. Forced Labour 111

$\begin{array}{ll}3.5 \text { Land Tenure } & 126\end{array}$

$\begin{array}{lr}3.6 \text { Women } & 130\end{array}$

$\begin{array}{ll}3.7 \text { Conclusions } & 136\end{array}$

4. Procedures 141

$\begin{array}{ll}4.1 \text { Introduction } & 141\end{array}$

4.2 Protection of Minorities and other Obligations of Newly- Independent $\begin{array}{ll}\text { Territories } & 142\end{array}$

$\begin{array}{ll}4.3 \text { Petitions } & 155\end{array}$

5. The Emergence of Rights Language and the South West Africa Cases of the International Court of Justice

5.1 The Continuation of the Mandate Without the League: The 1950

Advisory Opinion on the International Status of South West Africa

5.2 The Persistent Objector to Human Rights: The South West Africa

Cases of 1962 and 1966

5.2.1 The Plea for Self-government

5.2.2 Human Rights as Law or Morality? 193

5.2.3 Judge Fitzmaurice, the Formalist Jurist 195

5.2.4 Judges Jessup and Tanaka and the Critique of Formalism 196

$\begin{array}{ll}5.2 .5 \text { Disappointment } & 199\end{array}$

$\begin{array}{ll}\text { 5.2.6 Conclusions } & 203\end{array}$ 
5.3 The Court Redeems Itself: 1971 Advisory Opinion on the Legal Consequences for States concerning the Continued Presence of South Africa in Namibia

5.4 Conclusions on the South West Africa cases

6. Conclusions

Bibliography 


\section{Acknowledgements}

This thesis is the result of the assistance and guidance of several people. I would therefore like to offer my sincere thanks to all of them.

Firstly, I would like to thank my supervisor, professor Martti Koskenniemi. I am grateful for his immense knowledge, his patience and support, and for the keen interest he has taken in my project. The pre-examiners of this thesis have been professors Jan Klabbers and Jochen von Bernstorff. I extend my warm thanks to both of them. This thesis has benefited much from their insightful comments. Professor Jochen von Bernstorff has also kindly agreed to act as the opponent for the public defense of my thesis, which I thank him for. Professor Jan Klabbers has been a wonderful teacher and colleague throughout the years.

Jarna Petman has been a colleague, a teacher, a mentor, an office neighbour, and most importantly, a friend throughout the years I have been working at the Erik Castrén Institute of International Law and Human Rights. Her presence has made it more pleasurable to come to work when the thought of yet another day with the thesis has felt too daunting and her assurances that the project will one day come to an end have encouraged me to go on. Jarna, thank you.

The topic and focus of this thesis has taken its final shape during several years. Miia Halme-Tuomisaari and Pamela Slotte kindly asked me to write an article on the mandates system and human rights in their book "Revisiting the Origins of Human Rights" (Cambridge University Press 2015). While the initial focus of my thesis had been somewhat broader, writing and discussing the article made me understand what I needed to concentrate on and what I was really interested in. Overall, participating in the different phases of the book project was both stimulating and pleasurable and the author meetings both in Helsinki and New York provided me with invaluable advice and comments from all the contributors to the book. Thus, apart from thanking Miia and Pamela for their friendship that has become so important to me, I am grateful for them for the opportunity to find my true interest through participating in their book project.

I have had the great pleasure of working at the Erik Castrén Institute of International Law and Human Rights for many years in different positions, both administrative and research related. I have been able to benefit from the intellectual atmosphere of the institute, but even more I have valued the friendship and collegiality of all my co-workers. I am thankful for the coffee hours spent together, the numerous bottles of sparkling wine, the Christmas parties and the warm support of colleagues who have become friends. While being too numerous to thank you all, I would like to extend my thanks to Paolo Amorosa, María José Belmonte Sánchez, Martin Björklund, Tobias Bräutigam, Katja Creutz, Rotem Giladi, Mónica García-Salmones Rovira, Lauri Hannikainen, Manuel JiménezFonseca, Ville Kari, Katja Keinänen, Margareta Klabbers, Magdalena Kmak, 
Stiina Löytömäki, Anne-Charlotte Martineau, Ketino Minashvili, Ilona Nieminen, Sahib Singh, Ukri Soirila, Immi Tallgren, and Reetta Toivanen. Sanna Villikka has been the heart of the institute for many years. Thank you Sanna for all your help.

The Faculty of Law at the University of Helsinki has provided me with a position as the assistant of international law and I am grateful for that. I would especially like to thank Tarja Pellinen, former Head of Administration of the Faculty of Law, for taking care of the intricacies of my work contracts, my maternity leaves and reminding me that it is my duty to finish my thesis. Professor Pia Letto-Vanamo has encouraged me to concentrate on my research over other duties and Jutta Kajander has helped with the practicalities relating to the thesis. I have received grants from the Finnish Cultural Foundation, the Finnish Lawyers' Association, the OMY research school and a finishing grant from the Ella and Georg Ehrnrooth Foundation.

The main primary sources of my thesis, the minutes of the Permanent Mandates Commission of the League of Nations, have been available at the Library of Parliament in Helsinki. It has always been a pleasure to work at the library, and the helpful staff has generously given me access to the storage rooms to freely browse the materials at a time I still did not know what I was looking for. Later the staff has patiently searched for microfilms and other research materials for me to study and shown genuine pleasure in the fact that I was using the rarely accessed collections. Professor Samuel Moyn helped to get access to the wonderful libraries at Columbia University during the year our family spent in New York City. Heta Björklund has helped me to check and correct my footnotes and sources in the final stages of my thesis, and Juhana Heikonen has designed the cover for this book. Thank you both.

Finally, I would thank my family and friends for the love and support they have given to me. My parents Anniina and Ilpo Manninen have given me the initial spark to work in the field of international law by giving me and my sister Aino Peltokangas the opportunity to spend our childhood in different countries and giving us the possibility to follow important moments of international history close at hand. My sincerest thanks go to my husband Kaius for his love and for never losing his faith in my work and to our two sons Leo and Paul, our very own "sacred trust". This book is dedicated to my three boys.

Helsinki, November 14, 2016

Taina Tuori 


\section{Introduction}

After the First World War, the League of Nation mandates were established as a solution to the problem of what to do with the former colonies of the defeated states. An internationalized administration was set up in 1919 by the Allied powers, who occupied the former German colonies and some Turkish territories. After the war, these territories were transformed into mandates.

The story, as it is conventionally told, about the origins of the mandates system is one of a triumph of enlightened internationalism. In the formulation of the rationale of the mandates system, the drafters of the Covenant of the League of Nations found sources of inspiration from history. ${ }^{1}$ Spanish theologians and jurists had written about trusteeship as a moral concept and the humanitarian obligations towards the colonies in the $16^{\text {th }}$ century. ${ }^{2}$ In $18^{\text {th }}$ century Britain the idea of trusteeship was discussed in the context of the slave trade in government proclamations and parliamentary discussions. ${ }^{3}$ By the late $19^{\text {th }}$ century, humanitarian ideas regarding the colonies were already common. ${ }^{4}$

Humanitarianism derived not only from the anti-slavery movement and a more general idea of fairer treatment of natives, but colonial powers also realized that taking care of the welfare of the inhabitants would lead directly to greater productivity. ${ }^{5}$ For progressive colonial administrators the mandates system provided an opportunity for testing new ideas and new colonial practices. As much or even more than a system to promote the self-rule of the native peoples, the mandates provided the Allied states a means to avoid conflict that could have risen had they divided the spoils of war amongst themselves. ${ }^{6}$

Was there a difference between the old colonial administration and the mandate? Regardless of the growing importance of humanitarianism in the conventions ${ }^{7}$ regarding the colonies, the emerging humanitarian principles that guided the actions of the colonial states had no legal basis. They were, it has been argued, moral principles, based on Christianity and humanity. ${ }^{8}$ The mandates

\footnotetext{
${ }^{1}$ Chowdhuri, International Mandates and Trusteeship Systems, 36.

${ }^{2}$ Hall, Mandates, Dependencies and Trusteeship, 97; Chowdhuri, International Mandates and Trusteeship Systems, 35.

${ }^{3}$ Hall, Mandates, Dependencies and Trusteeship, 97.

${ }^{4}$ Koskenniemi, The Gentle Civilizer of Nations, 127-130; League of Nations, The Mandates System. Origin, Principles, Application, 8.

${ }^{5}$ League of Nations, The Mandates System. Origin, Principles, Application, 8.

${ }^{6}$ Knoll, The Legal Status of Territories Subject to Administration by International Organisations, 69.

${ }^{7}$ See e.g. Final act of the Berlin Conference of 1885.

${ }^{8}$ Liszt, Das Völkerrecht. Systematisch Dargestellt, 5; Oppenheim, International Law. A Treatise. Vol. I - Peace, 461-463.
} 
system supposedly transferred those principles into international law, bringing with it supervision and a higher authority. ${ }^{9}$

\subsection{The Research Question}

The purpose of this study is to trace the emergence of rights language in the League of Nations mandates system throughout its entire existence, beginning from its establishment to the legal proceedings concerning the last mandate, South West Africa, in the International Court of Justice.

The main research question is how rights vocabulary operated in the League of Nations and when human rights notions appeared in the language concerning the mandates. I will look at the transformation of the language of rights, the emergence of human rights notions and the change of legal culture with regard to rights. The years under scrutiny are 1921-1971. I will follow this issue through the question of how non-European communities were treated in international institutions, in the mandates system of the League of Nations and the post World War II decisions concerning the mandates by the International Court of Justice and whether the novel rhetoric of human rights in the United Nations system was applied to the mandates. The crucial points of interest are when particular concerns that would later be articulated in rights vocabulary are discussed, such as freedom of religion, freedom from slavery and compulsory labour, property rights, women's rights and minority rights. The underlying issue is not only the role of the mandates system in the history of human rights, but more precisely whether a discussion in the context of mandates is relevant and if so, in what way is it relevant. The aim of this study is to explore the process through which the rights vocabulary and ultimately human rights language emerged in the discussions over the mandates. Due to the complexity of the intellectual and legal currents that this study traces, it makes no claim to present a single explanation or a single cause. Multiple processes and many different intellectual and political actors and acts were involved, so that sometimes findings are contradictory and the significance of events was often unclear to contemporaries. The language of rights appears elusive and especially in the early stages of development, even anachronistic. The question of the emergence of something as fundamental and large scale as human rights is by its very nature one of viewpoint and to claim that such rights have a tidy lineage, a single cause or clear implications is

\footnotetext{
${ }^{9}$ League of Nations, The Mandates System. Origin, Principles, Application, 10; Anghie, 'The Heart of My Home, Colonialism, Environmental Damage and the Nauru Case', 456. "The mandate system was unique in establishing the principle of international accountability for the administration of the territory in question." Anghie argues that the fact that the obligations were made "justiciable" in the different mandates treaties reveals that the mandates system was based on legal duties. However, this was not clear even to the International Court of Justice decades later and does not tell what the original drafters intended. The justiciability clause of the different mandates (eg. Art. 7 of the Nauru mandate) were never applied during the League period.
} 
inappropriate. The struggle for rights is a matter of global development with a large cast of actors with often contradictory motives. Idealists, old colonial hands, politicians and international lawyers operated under rapidly changing global circumstances and public opinions in different countries negotiating, manipulating and bargaining through the epochal changes from the rule of colonial empires towards decolonization and rights.

This book is divided into three main chapters. In the first chapter I study the creation of the League of Nations mandates system and present its machinery. The central question of this chapter is what was the role of the conflicting ideas of tutelage and agency in the creation of the mandates system? On the one hand, there were old imperial ideals of civilization and humanitarianism and paternalism, and on the other new ideas of freedom, self-determination and development. For many of the statesmen and lawyers of the $19^{\text {th }}$ and early $20^{\text {th }}$ century who formulated the international legal system, Europe represented a universal standard of civilization. The "other" was welcome to join the international community when it was sufficiently similar to Europe. ${ }^{10}$ On paper at least, this applied to the mandates as well. Much of the establishing phase of the League of Nations can be seen as a direct continuation for the European-centred ideology of the late $19^{\text {th }}$ century. In the words of Lord Lugard, a longtime member of the Permanent Mandates Commission of the League of Nations, "It was the task of civilization to put an end to slavery, to establish Courts of Law, to inculcate in the natives a sense of individual responsibility, of liberty and of justice, and to teach their rulers how to apply these principles; ...". ${ }^{11}$ The duties of the mandatory states were described as "tutelage" and "trusteeship", and these were seen as a moral responsibility towards the natives..$^{12}$ It was said that the mandates system enabled the highest ideals of colonial doctrine and of advanced public opinion in civilized countries to be put into practice. Or, as Lugard described the mandates, they were "the latest expression of the conscience of Europe".13

Despite these continuities from the colonial period, the people within the League of Nations stressed how the mandates system was a new and novel start. The Permanent Mandates Commission of the League of Nations wanted to emphasize that they were forming a truly unique system, instead of being another way of colonizing states beyond the borders of Europe. The mandatory powers were expected to take into consideration native laws and customs and to safeguard native rights and interests.

\footnotetext{
${ }^{10}$ See, for instance, Lorimer, The Institutes of the Law of Nations, 102; Westlake, International Law, Part 1, Peace, 41, 46; Liszt, Das Völkerrecht. Systematisch Dargestellt; Gong, The Standard of 'Civilization' in International Society., 6-9; Koskenniemi, The Gentle Civilizer of Nations, 132136.

${ }^{11}$ Lugard, The Dual Mandate in British Tropical Africa, 5.

12 The term "native" is here used solely as a historical term as used by contemporaries to denote the indigenous inhabitants in opposition to European settlers.

${ }^{13}$ Lugard, The Dual Mandate in British Tropical Africa, 50.
} 
The ultimate goal for the mandates was to "stand alone under the strenuous conditions of the modern world". ${ }^{14}$ The means to achieve this could, however, be considered colonial. The aim of the Mandates Commission was to educate and to civilize, but it often appeared to lack the belief that some peoples actually could be civilized. One of the aims of education was to teach the natives to be useful in their own communities. However, a willingness to improve their position through education too much was disapproved of. It was not proper for the economic or political ambition of the natives to approach that of the European.

In the first chapter, I have examined international legal literature from the late $19^{\text {th }}$ and early $20^{\text {th }}$ centuries. This legal literature has a twofold role: on the one hand as research literature describing the changes in legal doctrine, on the other hand as a research subject illustrating the thinking of the period.

In the second chapter, I follow the emergence of the rights language in the minutes of the Mandates Commission during the years 1921-1939. Drawing from the discussions in the Permanent Mandates Commission, I will investigate thematically debates over issues that would later be articulated in rights language. The main perspective of this chapter is to show how these matters were formulated in the Mandates Commission through discussions echoing old colonialistic humanitarian paternalism but how there was also a gradual development of these discussions towards something new. The Permanent Mandates Commission discussed at length issues concerning freedom of religion, but privileged Christianity. They were concerned about the continuation of slavery but understood to some extent the need for compulsory labour. They discussed indigenous property rights but favoured economic progress. Issues concerning women's rights were likewise of concern but only when non-Western customs like polygamy or child marriage were at issue. They had a concern for minorities in Iraq, but had to give in to Britain's idea of an independent Iraq. Finally, I will study the issue of individual petitions to the Mandates Commission, which were authorized by the League of Nations in 1923. The system of petitions was not originally included in the mandates system and only later, did the League Council permit petitions from inhabitants from the mandated areas. ${ }^{15}$ The Permanent Mandates Commission considered petitions to be mainly a source of information, and deliberately did not turn itself into a court of appeals. ${ }^{16}$ However, in some mandates the petitions were a useful method of revealing grievances to the Permanent Mandates Commission, which was mainly dependent on the reports of the mandatories for information. In some cases, like petitions during the uprising in Samoa, they initiated processes that otherwise would have not taken place. ${ }^{17}$ The right to petition has in retrospect been considered by some authors to be the

14 The Covenant of the League of Nations (1924), Article 22.

15 Wright, Mandates under the League of Nations, 119.

16 Ibid., 171.

${ }^{17}$ See e.g. Pedersen, 'Samoa on the World Stage', 231, on the uprising in Samoa against New Zealand. 
most important human rights feature in the mandates system. Hersch Lauterpacht, for instance, called the right of petition a natural right, and maintained that the "right of petition was regarded as a natural concomitant of the system established by the Covenant". ${ }^{18}$ In his view, the hearing of petitions was one of the main features of the mandates system. ${ }^{19}$

When the League of Nations was established, the European-centred way of thinking transferred to the official discourse. In the second chapter on the rights language of the mandates system my main source is the minutes of the Permanent Mandates Commission of the League of Nations. In these papers the members of the Permanent Mandates Commission discussed in a detailed manner the relationship between the mandatories and the mandated territories, including the welfare (and rights) of the inhabitants.

In the third chapter I study the afterlife of the mandates, particularly the mandates cases in the International Court of Justice. The issue is how and when the language of rights and the framework of human rights were applied to the mandates and how they transformed the understanding of human rights in the context of international law. While the relevance of the League of Nations ended with the founding of the United Nations and most of the mandates it had established were turned into United Nations trusteeships, the mandates continued their relevance in international law through the International Court of Justice Mandates cases. Of the three sets of cases (South West Africa, Cameroon and Nauru), ${ }^{20}$ I will limit my examination to the cases concerning South West Africa or later Namibia. In these cases, the International Court of Justice revisited several times the meaning and content of the mandates, finally approaching them through the language of human rights. In the third chapter the case law of the International Court of Justice has been used as the main source.

The chief contribution that I seek to make with this study is to show how complex and multifaceted the processes of legal and conceptual change are. In some of the recent literature on the history of human rights there has been a tendency to search for fixed dates or points of origin. My intention is the opposite, showing developments over a long period of time and the change of interpretations and vocabularies as a gradual process where contradictory new

${ }^{18}$ Lauterpacht, International Law and Human Rights, 244.

${ }^{19}$ Ibid., 245.

${ }^{20}$ International Status of South-West Africa, Advisory Opinion of 11 July 1950; South West Africa Cases (Ethiopia v. South Africa; Liberia v. South Africa) Preliminary Objections, Judgment of 21 December 1962; South West Africa Cases (Ethiopia v. South Africa; Liberia v. South Africa), Second Phase Judgment of 18 July 1966; Legal Consequences for States of the Continued Presence of South Africa in Namibia (South West Africa) Notwithstanding Security Council Resolution 276 (1970), Advisory Opinion of 21 June 1971; Case Concerning Certain Phosphate Lands in Nauru, Preliminary Objections (Nauru v. Australia), Judgment of 26 June 1992; Case Concerning the Northern Cameroons (Cameroon v. United Kingdom) Preliminary Objections, Judgment of 2 December 1963. 
and old ideas coexist and debates are held. In particular, my aim is to track the slowness of changes in legal understanding and argumentation and how gradually through both external and internal developments new interpretations and conceptual frameworks emerge.

\subsection{Rights Language}

My research aims to trace the "emergence of rights language" in the League of Nations mandates system. Thus, I need to determine what exactly is the language that I am looking at and looking for. The lack of a fully-fledged modern rights language during my main period of research forces me to look at other concepts of rights language. Rights and rights language are complicated. It is used in numerous different ways to make claims, to criticize power, and so on. ${ }^{21}$ An additional problem is introduced by the fact that rights language was not in use in the League of Nations. An author writing in a period where even laymen tend to see legal matters through a lens of rights constantly faces the risk of anachronism when studying an era where rights language was not used to conceptualize legal issues. William Rappard's perplexity in a text written in the 1940 s is revealing. For the first time, he, a scholar who had devoted a great amount of his life to the mandates system, was asked what he thought of mandates in terms of human rights. "Asked by the editors of this volume to discuss the 'protection of human rights in mandated territories under the League of Nations', I must first define my subject. And that I can do only in the light of their intentions ... ."22 He reminds the reader that he has not visited the United States for years and has not had access to American literature. Thus, he could not "assess the true significance of the protection of human rights as provided for in the United Nations Charter". ${ }^{23}$ The concept was new and he was not sure what to make of it in relation to the mandates. In order to study "rights" language, I have had to liberate myself from searching for an exact language of human rights. In the absence of a modern vocabulary of rights language, I have examined discussions on land tenure, the obligations that newly-independent territories would have, the eradication of slavery, the issues of forced labour, the position of women and the liberty of conscience as arenas of proto-rights language. In these debates, issues that are currently understood as rights issues were discussed under concepts like guarantees, liberties, obligations, social problems, matters, questions, and, albeit

${ }^{21}$ Koskenniemi, 'Foreword: History of Human Rights as Political Intervention in the Present', xvi-xvii.

22 Rappard, 'Human Rights in Mandated Territories', 118; Yet, Rappard stated in 1933 that "Greater equality - that is, less discrimination on grounds of race, of sex, of religious and philosophical creed and of social position."... "Guarantees for the protection of the fundamental rights of man" were ideals which our forefathers had already fought for. Rappard, 'Nationalism and the League of Nations Today', 721.

${ }^{23}$ Rappard, 'Human Rights in Mandated Territories', 118. 
rarely, rights. ${ }^{24}$ As historical discourses, the languages of rights and colonial paternalism are intertwined and show parallel tendencies. One of the main justifications of European empires was that of the protection of the weak, for instance women and children. The similarities of language are often striking, while the aims, starting points and contexts were different. Thus, I have decided to use an ambiguous and open-ended concept of human rights. ${ }^{25}$ However, if one wants to find a common denominator for the rights that I am looking at, it could be the relationship between individual and administration, the League of Nations bringing an international element into this relationship. I have not sought for mentions of "human rights" until after the Second World War, when human rights began to be projected into mandates. One of the results of this research is to show that in legal practice mandates only became part of the human rights phenomenon in 1971.

An open attitude towards the concept of human rights helps us find, not perhaps predecessors or antecedents, but reasons and developments for the language of human rights becoming so powerful in the last decades of the $20^{\text {th }}$ century. ${ }^{26}$

The way one determines what one means by human rights has a significant outcome on the results of the historical enquiry. ${ }^{27}$ The idea of progressive development is an inherent part of universal and indivisible human rights. When those who think of human rights in terms of natural law, interpret the history of human rights as the history of rights consciousness, a narrative of linear development is naturally formed. ${ }^{28}$ Research in their history interferes with the purity of the evolutive narrative of human rights. A clear linear development is disturbed by documents and historic texts revealing the absence of the idea of human rights. ${ }^{29}$ The other end of the spectrum is represented by Samuel Moyn, who has looked at human rights as a "powerful transnational ideal and movement", to be invoked to transcend the authority of the state. Thus, rights within the state have no room in his historical approach. ${ }^{30} \mathrm{He}$ centres his examination on the international rights movement and maintains that human

${ }^{24}$ Carter Mills uses "prevention of abuses". Carter Mills, 'The Mandatory System', 55; while Fenwick uses "prohibition of abuses". Fenwick, International Law, 101.

${ }^{25}$ See, similarly, Halme-Tuomisaari and Slotte, 'Revisiting the Origins of Human Rights: Introduction', 22. See also Cmiel, 'The Recent History of Human Rights', 119.

${ }^{26}$ See also Karlsson and Lindkvist, who maintain that "a critical reading of the reasons of human rights politics and practice is meaningful only when a realistic historical study helps us understand how the heterogeneous human rights language can act as emancipatory" (translation by author). Karlsson and Lindkvist, "Triumf, Tröstpris Eller Öppen Praktik? De Mänskliga Rättigheternas Historia', 99.

${ }^{27}$ Rappard, 'Human Rights in Mandated Territories', 118.

${ }^{28}$ Koskenniemi, 'Foreword: History of Human Rights as Political Intervention in the Present', ix.

${ }^{29}$ Gearty, 'Afterword', 381.

${ }^{30}$ Moyn, The Last Utopia: Human Rights in History, 7. 
rights were a phenomenon of the 1970s. ${ }^{31}$ In the following, I will explore this idea using Philip Alston's schematic on the approaches to the history of human rights as a starting point. ${ }^{32}$

The standard way of narrating the history of human rights in many textbooks has been to lead the reader through certain landmark documents, usually starting from the British Bill of Rights, the American Declaration of Independence, the French Declaration of the Rights of Man and of the Citizen ${ }^{33}$ (and sometimes even going back as far as the Magna Carta of 121534) and then continuing, through some setbacks and denials in the $19^{\text {th }}$ and early $20^{\text {th }}$ centuries to the establishment of the United Nations Declaration of Human Rights. However, most textbooks do mention some other documents along the way.

Some authors include certain fields of international law in their historical narrative that they consider to be close to human rights, such as humanitarian law or diplomatic protection, while not at the same time recognizing them as full human rights. ${ }^{35}$

There is variation in what documents and events are placed in the human rights narrative, but in many of these accounts the League of Nations and the mandates system have played a part in telling the human rights story. ${ }^{36}$

${ }^{31}$ Ibid., 7-8.

32 Alston, 'Does the Past Matter?'

33 Asbjørn Eide discusses Abraham Lincoln's campaign to abolish slavery within the light of the economic and social rights of the $19^{\text {th }}$ century. However, the "cradle of discourse on rights" according to him goes even further back, to the "British, French and American thinking in the seventeenth century." Eide's narrative is linear by nature: "The way in which these issues have been addressed has matured over time, from initial, idealistic assertions of vague principles to the adoption of the comprehensive, international normative system now in existence." Eide, 'Economic, Social and Cultural Rights as Human Rights', 25-28. Olivier De Schutter also points out that human rights "already had a long history" before emerging "as part of international law in 1945". In this context he lists the constitutions of the late $18^{\text {th }}$ century and $19^{\text {th }}$ centuries. De Schutter, International Human Rights Law, 3-8.

${ }^{34}$ Rhona Smith looks further back in her historical introduction, namely to the Magna Carta of 1215: "the existence of a body of basic rights can be traced back to the early thirteenth century in Europe". After that, she follows the standard narrative, noting the late $18^{\text {th }}$ century documents to be "modern equivalents in human rights instruments" and (after a mention of diplomatic law, humanitarian law, law of aliens, slavery, minority rights, ILO conventions) places the "launch of contemporary human rights" in the UDHR. Smith, Textbook on International Human Rights, 5, 22.

35 De Schutter, International Human Rights Law; Nowak, Introduction to the International Human Rights Regime.

${ }^{36}$ Christian Tomuschat mentions the 1815 declaration on the abolition of slave trade; freedom of conscience and religion and the slave trade; arms traffic and liquor traffic in Art. 22 of the Covenant of the League of Nations; the fair and humane condition of labour for men, women, and children in Art. 23 as "some minimum guarantees"; and the "deficient" petition system and the minorities system and the ILO. Tomuschat, Human Rights: Between Idealism and Realism, 16-17; Nowak sees the importance of mandates in two ways. Firstly, he lists self-determination as an antecedent to human rights and gives the 
Philip Alston has described three different approaches to research on the history of human rights. ${ }^{37}$ Firstly, there is the narrative of linear development. By this he means researchers that have aimed to show that there is a linear progress that has gradually progressed into present-day human rights. These narratives have as their standpoint an evolution which has culminated with perhaps a few setbacks $^{38}$ in modern-day human rights. Many of these studies start as far back as ancient history, for instance ancient Rome or even the Bible. An example of this kind of narrative is Micheline Ishay's The History of Human Rights: From Ancient Times to the Globalization Era (2004), in which she draws a linear narrative from "early ethical contributors", such as the Babylonian laws, the Bible, early Hebrew laws and the Quran ${ }^{39}$ to the present, emphasizing the role of those outside the realms of power. ${ }^{40}$ She describes her view on human rights as "[h]uman rights are thus seen here as the result of a cumulative historical process that takes on a life of its own, sui generis, beyond the speeches and writings of progressive thinkers, beyond the documents and main events that compose a particular epoch .... One

mandates system a role in this context. In addition, "mandates treaties ... lay down minimum rights for the people living in the territories under mandate. Some of these minimum rights, such as the prohibition of torture [sic], were not unlike human rights". Nowak, Introduction to the International Human Rights Regime, 17-20. He claims that the supervision and petitions can be seen as the beginning of the individual complaints procedures in human rights instruments. Nowak's approach is also adopted in some major international law text books. In the earlier versions of his textbook, Ian Brownlie places both the League minorities regime and the mandates regime under the rubric "international protection of human rights", but does not elaborate on the reasons for his classification. Brownlie, Principles of Public International Law, 1998. However, from the sixth edition onwards, he notes that " $[t]$ he appearance of human rights in the sphere of international law and organizations is often traced to the era of the League Covenant of 1919, and the Minorities Treaties and League of Nations mandated areas which were associated with the Covenant...". However, "neither the Mandates system nor the Minorities regimes were representative in character". Brownlie, Principles of Public International Law, 2003, 530; Crawford, Brownlie's Principles of Public International Law, 635. Brownlie also mentions the establishment of the League of Nations as an "important change", noting particularly Article 22 of the League Covenant and the freedom of religion and duty to report in mandates, and Article 23 on just treatment of the native population of the territories in question. Shaw, International Law, 271; Buergenthal, Shelton and Stewart also note Articles 22 and 23 of the League Covenant as provisions that "bear on the development of international human rights law". Buergenthal, Shelton, and Stewart, International Human Rights in a Nutshell. Buerghental maintains that the mandates system consisted of "rudimentary normative and institutional processes for the protection of the indigenous populations of some former colonies". However, they did not result "in a comprehensive body of law that could be denominated international human rights law”. Buergenthal, 'The Evolving International Human Rights System', 783.

${ }^{37}$ Alston, 'Does the Past Matter?'

${ }^{38}$ On setbacks, see Ishay, The History of Human Rights from Ancient Times to the Globalization Era, 4 .

${ }^{39}$ Ibid., 18-61.

40 Ibid., 2. 
may thus think of the history of human rights as a journey guided by lampposts across ruins left behind by ravaging and insatiable storms". ${ }^{41}$

Similarly, Paul Gordon Lauren, in The Evolution of Human Rights: Visions Seen (1998) approaches the history of human rights through "visions" of human rights advocates in different eras. ${ }^{42}$ He claims that such visions over the centuries and in different geographic locations, though having resulted in many visions of human rights rather than one, unified one,43 have led to "what is now described with confidence as a 'universal culture of human rights'”. ${ }^{44}$ His path to mapping the visionaries starts by describing the issue of human responsibility in the major religions of the world as well as philosophers in places and times as distant as China twenty-four centuries ago, ancient Babylon, Sanskrit writings from India, and the tenth-century Middle East. ${ }^{45}$

A different approach was taken by what Alston has called precise timeframe theories. Precise timeframe theories include research that has placed an individual event or moment as the starting point of human rights. Such moments include the French and American Revolutions ${ }^{46}$ or the Universal Declaration of Human Rights. However, the abolitionist movement of the $19^{\text {th }}$ century and the prohibition of the slave trade have also been mentioned in this context, as well as the period of decolonization in the $1960 \mathrm{~s} .{ }^{47}$

Lynn Hunt claims that the two $18^{\text {th }}$ century declarations, the US Declaration of Independence of 1776 and the French Declaration of the Rights of Man and Citizen of 1789 were based on a claim of the self-evidence of human rights and that this claim was "crucial to the history of human rights". ${ }^{48}$ Thus, her aim to prove the existence of human rights in the late $18^{\text {th }}$ century means proving their self-evidence in that period. When searching for human rights, she finds that they have three essential qualities: they must be natural, equal and universal. ${ }^{49}$ They must also have political content in a human society. ${ }^{50}$ She asks why self-evidence crystallized as human rights in the late $18^{\text {th }}$ century. Lynn Hunt acknowledges

${ }^{41}$ Ibid., 2-3.

${ }^{42}$ An approach similar to Ishay's and Lauren's has been taken by Ove Bring. Bring, De Mänskliga Rättigheternas Väg.

${ }^{43}$ Lauren, The Evolution of International Human Rights: Visions Seen, 2.

${ }^{44}$ Ibid., 3.

${ }^{45}$ Ibid., 5; Moyn leaves Lauren's and Ishay's book outside his scope of "professionalized" human rights histories announcing them "ultimately an idealist and decontextualized exercise in teleological conceptual accumulation". Moyn, 'Substance, Scale, and Salience: The Recent Historiography of Human Rights', 127.

${ }^{46}$ Lynn Hunt and others.

${ }^{47}$ Martinez, The Slave Trade and the Origins of International Human Rights Law; Jensen, The Making of International Human Rights. The 1960s, Decolonization, and the Reconstruction of Global Values.

${ }^{48}$ Hunt, Inventing Human Rights, 19-20.

${ }^{49}$ Ibid., 20.

${ }^{50}$ Ibid., 21. 
that as the claim of self-evidence is largely based on Western history, emphasizing self-evidence as central to the history of human rights risks such history becoming the history of Western civilization. ${ }^{51}$

Jenny Martinez claims to offer an alternative to the "standard account" that begins from the Second World War. She asserts that the prohibition of the slave trade gave a basis for present-day human rights, but admits that these rights did not yet resemble each other very much. She makes a straightforward move from the humanitarianism of the $19^{\text {th }}$ century to the present day. She notes that the antislavery movement used the language of humanitarianism (or even human rights on some occasions). Yet, she does not find the connection problematic, as she believes that the language of human rights is based on the same humanitarianism. ${ }^{52}$

Martinez correctly notes the gap in the many historical accounts in which the history of human rights makes a leap from the late $18^{\text {th }}$ century to the mid $20^{\text {th }}$ century. ${ }^{33}$ According to Martinez, pieces are missing from between these periods, and only now researchers are starting to find them. In her view, the prohibition of slavery is one of the pieces that has been missing. ${ }^{54}$ Martinez has also aimed to show that the abolitionist movement was a human rights movement because its members use the term "rights". Martinez has replied to the criticism that she has received on the terminology having a very different meaning in the $19^{\text {th }}$ century than it has now, ${ }^{55}$ noting that there are so many different meanings of human rights even now that the criticism is not valid. ${ }^{56}$

Roland Burke's study of the post-colonial movement shaping the evolution of human rights cannot be considered a book about the origins of human rights as such, since he is not interested in the initiating processes, but rather, in the "vital years and forgotten voices that have been missing from human rights historiography" ${ }^{57} \mathrm{He}$ argues that the process of decolonization was essential to the UN human rights agenda, with, however, complex results. ${ }^{58}$ According to him, "the politics of anticolonialism both advanced and obstructed the progress of international human rights". ${ }^{59}$ Similarly, Stephen Jensen maintains that in the recent human rights histories the $1940 \mathrm{~s}$ and the 1970s have become overemphasized. Rather, he claims that the period between these decades is particularly important for the study of the history of human rights. In Jensen's view, research has forgotten the importance of a human rights agenda by

${ }^{51}$ Ibid., 20.

52 Martinez, The Slave Trade and the Origins of International Human Rights Law, 134-139.

${ }^{53}$ Ibid., 148-149.

${ }^{54}$ Ibid., 149.

55 Alston, 'Does the Past Matter?', 2051.

${ }_{56}$ Martinez, 'Human Rights and History', 224.

${ }^{57}$ Burke, Decolonization and the Evolution of International Human Rights, 2.

${ }^{58}$ Ibid., 4.

${ }^{59}$ Ibid., 6. 
countries and actors from the South, such as Jamaica, Ghana, the Philippines, Liberia, Costa Rica and Senegal. He maintains that these groups left legacies still prevalent in human rights politics, in mechanisms such as fact-finding missions, national human rights commissions, regional human rights mechanisms etc. Moreover, these actors redefined international human rights around racial discrimination and religious intolerance. Jensen believes that current research has focused too much on international legal standards and has thus blurred the view of a more nuanced and pluralist understanding of the history of human rights. ${ }^{60}$

Reza Afshari has criticized viewing single-issue movements as human rights movements, since these movements did not see themselves as such in their early stages. ${ }^{61}$ For instance, liberating slaves, working conditions and land matters were much more important than human rights thought. These discussions did not aim to expand to include equality and common human rights. ${ }^{62}$ Afshari gives examples of how single-issue movements during the interwar era blurred human rights violations elsewhere. Those encouraging the self determination of nations were not too enthusiastic about the legitimacy of the same demand when it was forwarded by minorities in their own countries. When the Japanese aimed to have the League of Nations accept the equality of all races, they had no intentions to improve the human rights of people in the countries they had conquered. ${ }^{63}$ Of course, the same argument could be said elsewhere: the European Convention of Human Rights was meant to secure nations and people against an outside threat, and the parties hardly imagined having to be called in front of the Court themselves. (For this reason, Moyn leaves the establishing of the European Convention outside his scope of the history of human rights. ${ }^{64}$

The next wave of history of human rights research Alston calls the "new revisionists". The new revisionists claim that no continuation exists between earlier events (mainly those prior to the Second World War) and the human rights thought of the past decades. This strand of research started with the publication of Samuel Moyn's The Last Utopia: Human Rights in History (2010). While Moyn has been the most prominent historian to represent this group, others, such as Robin Blackburn (The American Crucible, 2011) and Stefan-Ludwig Hoffmann (editor of Human Rights in the Twentietb Century, 2011) should be included.

Samuel Moyn also finds a similar divide in research on the history of human rights. He divides the research on the history of human rights into three groups. In the current human rights studies, he finds substantive history in which the contents and meanings of human rights norms are examined. The approach in these studies is usually national, meaning that the origin of the norm is sought in

\footnotetext{
${ }^{60}$ Jensen, The Making of International Human Rights.

${ }^{61}$ Afshari, 'On Historiography of Human Rights: Reflections on Paul Gordon Lauren's The Evolution of International Human Rights: Visions Seen', 65.

62 Ibid., 66.

${ }^{63}$ Ibid., 42-43.

${ }^{64}$ Moyn, The Last Utopia: Human Rights in History, 79-80.
} 
national documents. ${ }^{65}$ Moyn notes that such research is mainly conducted by international lawyers and is the most common approach in human rights textbooks. ${ }^{66}$ The earliest versions of this kind of research is from the 1970s. Under this group he also includes a subgroup, among them Lauren and Ishay, which he calls the "teleological historians". Moyn describes them as idealistic, their work being an "exercise in teleological conceptual accumulation", and to whom the leap from national to global is only achieved by "hope and striving". ${ }^{67}$

Moyn, even when criticizing Lynn Hunt for her reinterpretation of late $19^{\text {th }}$ century revolutions as human rights, gives her credit for her move "beyond a substantive account of the accumulation for instrumentalized precedents" and towards a salient analysis, according to which human rights are about political and social transformations. ${ }^{68}$ Moyn also credits Hunt for establishing the field of research, but criticizes her for not taking scale into account. Likewise, he agrees that Martinez could be right in her claim that opposing the slave trade was the first occasion when people other than a country's own nationals were protected by international law, but that this would count as protecting human rights does not pass the "scalar test". Of the mandates system he notes that even though it is related to matters that were later conceptualized as human rights, "[t]o analyze a remote past in light of what frameworks later crystallized around its problems is to join bandwagons rather than to write history." 69 Moyn praises those who emphasize the meaning of the $1940 \mathrm{~s}$ in the birth of human rights (e.g. Brian Simpson) in that they take scale into consideration. However, he claims that these studies have a problem of sidelining "popular reception and political impact". ${ }^{70}$ Moyn believes that all of these approaches have something to give to the research of the history of human rights. However, one approach in isolation from others is not sufficient. ${ }^{71}$

Even though there has been a shift towards salience in studying the history of human rights, Moyn writes that precisely this has made those studying the 1940s wonder whether some other approach than human rights could be more fruitful. ${ }^{72}$ For instance, the documents that have been established within the framework of the United Nations do not mean that human rights would be "salient" within the

\footnotetext{
65 Moyn, 'Substance, Scale, and Salience: The Recent Historiography of Human Rights', 126.

66 Ibid., 127.

67 Ibid., 127-128.

68 Ibid.

${ }^{69}$ Ibid., 132.

70 Ibid., 128.

71 Ibid., 129.

72 Ibid., 132.
} 
United Nations or outside it. ${ }^{73}$ Similarly, he denies the meaning of human rights in decolonization. ${ }^{74}$

Stefan-Ludwig Hoffman draws a familiar line from the late $18^{\text {th }}$ century revolutions to the post World War II era, pointing out to the reader however its disappearance from political and legal discourse from the $19^{\text {th }}$ century onwards. ${ }^{75}$ He notes, however, that human rights gained their meaning as the language of global morality only in the last two decades of the $20^{\text {th }}$ century. ${ }^{76} \mathrm{He}$ also criticizes the triumphalism of the recent historiography of human rights that distort the subject of its research (e.g. slavery). ${ }^{77}$

Philip Alston finds shortcomings in all of the above approaches. Firstly, according to him, the main problem in linear narrative approaches is that they are lacking in causal analysis. The researchers move from one historic event to another one without analyzing the causal connections between them. They emphasize coherence and continuity and marginalize alternative ways of looking at matters. Their research turns all history into human rights history, because all events receive a meaning and interpretation in the context of the history of human rights. On the other hand, Alston finds precise timeframe approaches problematic in their faith in a pure, mythical starting point. He also maintains that the fact that there are so many competing theories on what the actual starting point is, is in itself a sign that this approach is not a very fruitful point of departure for research. Alston applauds the "new revisionists" for bringing fresh air into the history of human rights discussion by forcing the field to re-examine many premises that have been considered self evident, e.g. a certain triumphalism common to many studies. However, he thinks that the revisionists' ideas are lacking in nuance and that they are too polemical and too narrow in sidelining many rights narratives. First of all, they do not take into consideration the long history of human rights in national constitutions. Secondly, he believes that their tendency to count as human rights only those rights that are above and outside the states is too narrow. Thirdly, he questions the fact that Moyn does not view the establishment of the European Convention of Human Rights as a relevant part of the history of human rights. Alston also lists other factors that Moyn has not taken into consideration, including individual lawyers, researchers and activists who have worked to promote human rights, the movement against racism, minority rights, the labour movement, the women's rights movement, movements promoting children's rights, and other single-issue movements.

One of the main questions in Alston's critique is how human rights are defined. He notes that the representatives of these different approaches to human

\footnotetext{
73 Ibid.

${ }^{74}$ Ibid., 133; Moyn, The Last Utopia: Human Rights in History, 84-.

${ }^{75}$ Hoffmann, 'Introduction. Genealogies of Human Rights', 1.

76 Ibid., 2.

77 Ibid., 3.
} 
rights history partly talk about different things. Martinez, for instance, looks at the legal and institutional features of the human rights system and searches for commonalities in earlier times. Alston is also critical of Martinez's way of emphasizing the historical uses of "human rights". In her book Martinez often refers to human rights as the starting point of $19^{\text {th }}$ century abolitionists. Was the term human right (or even right) used in the $19^{\text {th }}$ century? And if in individual cases it was (as Martinez claims), what was meant by the term at that time? Alston finds Martinez's examples of the usage of "human rights" merely anecdotal. Moyn, on the other hand, requires that human rights and the human rights movement are defined by those global norms that are driven by supranational movements. He does not accept the meaning of human rights unless they have achieved a certain status and a global reach. ${ }^{78}$

Alston questions whether there is a need for a genealogy of human rights in general. Does it matter if the origins of human rights can be traced back for centuries or not? Jenny Martinez believes that genealogy does matter, because to her genealogy has a role in how we think about human rights. She believes that the events of the $19^{\text {th }}$ century have a significant influence on how we discuss human rights today. She even believes that her findings could change how we think about the entire field of human rights, and its origins, limitations and possibilities. ${ }^{79}$ However, Alston notes that Martinez mainly leaves the conclusions on how this would happen to the reader. According to Alston, Moyn is correct in claiming that historical research of human rights by lawyers has been superficial, but wrong in maintaining that there was no human rights movement before 1977. At the same time, Alston criticizes the revisionists for claiming that genealogy has no meaning. In his view, the way that one generation uses a given term gives a basis for how the term develops in the usages of future generations. Terminology in different periods relates to the ways in which it is used by the following generations. The next generation does not develop terminology in a vacuum. Even when terminologies change, they are part of the same historical process. Alston believes that the discussion that has been taking place on the origins of human rights is the result of researchers being able to see the polycentric nature of human rights. He thinks that one cannot look at human rights through a single lens without seeing a distorted picture. Anne Orford, writing on genealogy, points out that for a lawyer tracing a certain concept historically does not only mean that one is trying to figure out and explain the past, but that law is "inherently genealogical, depending as it does upon the movement of concepts, languages and norms across time and even space". ${ }^{80}$ When using law, one will encounter norms that have been interpreted in the past, and therefore the past is visible in legal actions today. According to her, the difficulty is in finding the precedent that make the acts of

\footnotetext{
${ }^{78}$ Alston, 'Does the Past Matter?', 2073.

${ }^{79}$ Martinez, The Slave Trade and the Origins of International Human Rights Law, 15.

${ }^{80}$ Orford, 'The Past as Law or History?', 9.
} 
today more understandable. In this research this has been apparent in the different ways in which the ICJ has interpreted the mandates system in different cases.

Common to all Alston's critique is terminology. He criticizes all history of human rights research approaches by claiming that the chosen terminology leads the research to a predetermined conclusion. Thus, the choice of terminology defines the end result. There is a certain relativism to Alston's approach. He does not believe in grand narratives or the possibility of finding a "truth". Alston's critique that the definition chosen by Moyn limits the end result should be taken seriously. On the other hand, Alston himself gives so many different options that there is a danger that they are not very useful in trying to determine the actual content and field of the research. Alston's view on the polycentricity of human rights means that there is an unlimited number of discourses, institutions, documents, etc. that one could see (or not see) as some kind of an antecedent to what we see as human rights now. Thus, we will end up not saying very much. At the same time, there is a danger that one cannot approach the question of genealogy at all, as dangers linger everywhere. Also, Alston is unable to hide his distaste for the polemical style of the revisionists, and resorts to simplifying their arguments.

In conclusion, it is true that researchers in the history of human rights spend too much energy in attempting to outwit each other. In contrast, my aim is to step back from such grand explanations in order to investigate the complexities of legal change. What is most interesting about human rights history research is finding meanings, connections and differences in small streams, rather than yearning for large, overarching explanations. Anne Orford has made a similar claim when describing her method when working on International Authority and the Responsibility to Protect (2011). Contrary to her initial aims, she decided to start with practices and then move on to systematize them and articulate them in broader terms. She claims (relying on Foucault) that "only by understanding the relations that existed within a language or a society that it was possible to understand all the modifications that had to take place in order for one of the elements to change". ${ }^{81}$ Instead of searching for universal truths, she calls her working method "description", maintaining that the "work of description (or re-description) requires an attention to facts and values, where both are understood as historical creations rather than timeless givens" ${ }^{82}$ In my thesis I shall describe language and discussions from both the interwar years as well as the post World War II period. These descriptions reveal both continuities and discontinuities. For example, important matters did happen in relation to the slave trade in the $19^{\text {th }}$ century (particularly the abolition of the slave trade), but yet, in the $20^{\text {th }}$ century the abolition of slavery was slowed down by very practical and mundane matters, for

\footnotetext{
81 Orford, 'In Praise of Description', 618.

82 Ibid., 624.
} 
example paying compensations to former slave owners. Moreover, if rights were discussed, the point of view taken was that of the slave owners, not the slaves themselves. On the other hand, slavery was at least discussed and attitudes very slowly changed. Then again, the language that derives from the interwar years was used by the ICJ for two decades after the end of the Second World War. One could think that smaller-scale research on the history of human rights focusing on different details would tell us more about the past of human rights than attempts at large, all-embracing syntheses.

\subsection{Mandates and International Law}

The legal side of the mandates has remained of little interest. ${ }^{83}$ Antony Anghie has studied the development of international law through colonial history and the mandates. His central thesis is that the colonies had an important effect on the development of international law and particularly the notion of sovereignty, and that imperialism has affected the entire field of international law. International law emerged from the need to develop a legal system that would regulate the relationships between European states and non-European areas during the colonial period. He maintains that this relationship is repeated in the different phases of international law, including the mandates period and in the relations between the Western world and third world countries after the Second World War. Both the civilizing mission and imperialism are themes that are relevant to the entire history of international law. ${ }^{84}$ Implicit was the division between the civilized and the non-civilized, where the latter could be removed from the sphere of international law and admitted inside the sphere only by accepting the conditions set by the Europeans. Having said that, Anghie considers the mandates to be an important innovation in international law. ${ }^{85}$ The contradiction within the mandates was that their aim was to further self-government, but at the same time they created a structure that replicated colonial relationships. ${ }^{86}$ The mandates system, for one thing, brought new technologies to colonial administration, ${ }^{87}$ challenging $19^{\text {th }}$ century positivist ideas about sovereignty and introducing new ways to approach questions of sovereignty. ${ }^{88}$ On the other hand, international

83 Most notably Anghie, Imperialism, Sovereignty, and the Making of International Law; and Anghie, 'Colonialism and the Birth of International Institutions: Sovereignty, Economy, and the Mandate System of the League of Nations'; See also Wilde, International Territorial Administration. Wilde treats the mandates as part of the same continuity as colonialism and occupations, but also more recent experiments in international administration, such as in Kosovo and East Timor. He rejects the idea that the administration of the lattermentioned territories would have been unprecedented.

${ }^{84}$ Anghie, Imperialism, Sovereignty, and the Making of International Law, 316.

85 Ibid., 191.

86 Ibid., 192.

${ }^{87}$ Ibid., 195.

${ }^{88}$ Ibid., 125. 
institutions had the task of creating sovereignty in territories where it had not existed before ${ }^{89}$ and the civilizing mission aimed at moulding non-European territories according to European legal thought. ${ }^{90}$ Anghie suggests that the notion of "well-being and development" had mainly an economic meaning and that the aim was to develop the mandates furthermost economically, which of course was on many occasions in conflict with the aim to increase the welfare of the natives. ${ }^{91}$

The League of Nations mandates system is not usually mentioned in connection with human rights; it is dropped from the human rights narrative, or if considered, regarded as uninteresting. ${ }^{92}$ However, some efforts have been made in trying to bring features of the mandates system into the human rights success story. One group of such efforts is to place some issues relevant to the mandates system, such as the freedom of conscience and religion, prohibition of the slave trade, etc., into the human rights narrative, or the petitions system established a few years after the establishment of the mandates system. On the other hand, the mandates have also been seen as a step in the right towards self-determination. This has been done by the International Court of Justice in the case of Namibia in 1971, and this has been confirmed by several commentaries on the case.

The existence of the mandates system did not fully end with the Second World War, as there were three major continuities. First, some of the mandated areas continued their existence as United Nations trusteeships, which meant that the relevant articles of the United Nations Charter reflected the human rights language prevalent in the UN. Second, through the International Court of Justice and the impact its cases regarding mandates had over the formation of international law, the mandates system was integrated into the discussion on international law. Criticism over the South West Africa cases was strong and to a large extent influenced the Court to change its rhetoric and its motivations in the Namibia judgment and its later practice. In the 1971 Namibia case, the ICJ finally began to discuss human rights. As the Court itself has later referred to the case on numerous occasions, its impact has grown. Third, immediately after the Second World War human rights lawyers began to give the mandates meanings that they did not have during their actual administration and started to discuss mandates and human rights in the same context. ${ }^{93}$

\footnotetext{
${ }^{89}$ Ibid., 133.

${ }^{90}$ Ibid., 146; Donelly, 'Human Rights: A New Standard of Civilization?', 6.

${ }^{91}$ Anghie, Imperialism, Sovereignty, and the Making of International Law, 156.

${ }^{92}$ See, for instance, Pedersen, 'Did "Imperial Trusteeship" Have Anything to Do with "Human Rights"?'. See also Moyn, 'Substance, Scale, and Salience: The Recent Historiography of Human Rights', 131-132; However, Kevin Grant believes that there is not enough research on the development of human rights during the interwar period. Grant, 'The British Empire, International Government, and Human Rights', 576.

${ }^{93}$ Hall, Mandates, Dependencies and Trusteeship, 128 (on the assumption of democracy in the League of Nations) and 198 (on petitions as a natural right); Lauterpacht, International Law and Human Rights, 244 (also on petitions as a natural right).
} 
Duncan Hall saw the safeguard clauses in the mandates as parallels to the human rights clauses of the United Nations Trusteeship system. "In both periods of resettlement [i.e. after both World Wars], guarantees of the protection of racial minorities and 'human rights' were required in the area of Central Europe and the Middle East. The human-rights clauses of the peace treaties in the second world settlement, and in all the trusteeship regimes set up under the United Nations, had their parallels in the minority treaties of 1919-23 and in the minority and other safeguard clauses in the League mandates." 94 Hall's book on the mandates was published in 1948, when the UN trusteeship system with its references to human rights was already in place.

In 1943 the American political scientist and professor of international law, Quincy Wright, connected certain aspects of the mandates with human rights. In providing his version of the history of "individual rights", Wright found "certain underprivileged classes" to receive new protection by international legislation. Here he mentions the abolition of slavery, and the Treaty of Berlin of 1878 and the Berlin Act of 1885 extending certain rights to minorities in Turkey and to aborigines in central Africa respectively. After World War I, he found the mandates, minority treaties and international labour conventions to produce "extensive codes of rights of native peoples; of religious, cultural, and linguistic minorities; and of laborers", however, "limited in most cases to particular areas." Nevertheless, "The theory of these treaties goes beyond the right to States to protect their nationals abroad and approaches an international recognition of human rights." 95

Hersch Lauterpacht would concentrate his human rights efforts on the establishment of an International Bill of Rights of Man, which kept him occupied much of the immediate years after the Second World War. ${ }^{96}$ While he was pessimistic about humanitarianism in the League era, he would promote the right to petition by arguing that it was a natural right already during the League period. ${ }^{97}$

In a more recent account, Judge Cançado Trindade, in his separate opinion on the advisory opinion for the Accordance with International Law of the Unilateral Declaration of Independence in Respect of Kosovo, gives a lengthy account of his ideas on the humanitarianism of mandates (and their relation to the Kosovo administration). He saw the mandates system as emerging from "human

\footnotetext{
${ }^{94}$ Hall, Mandates, Dependencies and Trusteeship, 15; Hall's view can be seen as an example of triumphalism, as Samuel Moyn has called the phenomenon. Moyn, The Last Utopia: Human Rights in History, 311.

${ }^{5}$ Wright, Human Rights and the World Order, 255.

96 Koskenniemi, 'Lauterpacht: The Victorian Tradition in International Law', 246; Bernstorff, 'The Changing Fortunes of the Universal Declaration of Human Rights: Genesis and Symbolic Dimensions of the Turn to Rights in International Law', 907.

${ }^{77}$ Lauterpacht, International Law and Human Rights, 244.
} 
conscience" as a reaction to "abuses of the past". ${ }^{98}$ In his view, case law of the PCIJ (which does not have anything to do with mandates as such) showed that the principle of equality and the prohibition of discrimination existed before the Universal Declaration of Human Rights, which then broadened such principles also to those who did not belong to a minority or who were not an inhabitant of a mandated territory. "Yet, the formulation of the principle in relation to those pioneering experiments under the League of Nations (the minorities and mandates systems, this latter followed by the trusteeship system under the United Nations), contributed to giving universal expression to equality and non-discrimination. Yet, the principle of equality and non-discrimination was already engraved in human conscience." 99

These lawyers were in part creating the language of human rights and gave new significance to old practices. In this context certain treaties were interpreted as human rights treaties, for example the convention on the prohibition of slavery and the treaty banning forced labour. Even though the actual administration of the mandates had little or nothing to do with human rights, the mandates system could be seen as a more humane regime in comparison to traditional colonial rule. The mandates system was the first international institution where certain demands of humanity and the welfare of the people were written down into the system and were evident in the international regulation and administration of the institution. There were established controls over how the mandatories would fulfil their obligations concerning the well-being of the population of the mandated areas. Yet, for the mandatories, the mandates system appeared to be only a little different from the previous colonial administration and to some extent the Mandates Commission shared this view.

\subsection{Colonies and the Language of Humanitarianism}

Colonial ideologies for most of the $19^{\text {th }}$ century circled around economic theories of market and trade. Colonies were taken for strategic reasons as part of power politics and to settle inhabitants from areas where there was overpopulation. One of the most important motives for colonialism, however, was the expansion of trade. Thus, the language of colonialism during this period was also the language of economics. ${ }^{100}$

The Berlin Conference of 1884-1885 was a turning point in the language and the expressed ideology of colonialism. The conference was initiated at a moment when Germany and other countries joined Britain and France as colonial nations. Therefore, new rules were needed to deal with the possible differences between the colonial powers and to regulate trade amongst them.

98 Accordance with International Law of the Unilateral Declaration of Independence in Respect of Kosovo, Advisory Opinion, I.C.J. Reports 2010, p. 403, para. 54.

${ }^{99}$ Ibid. para. 83.

100 Anghie, Imperialism, Sovereignty, and the Making of International Law, 67-69. 
In addition to dividing colonial spheres of influence, the question of the legal personality of natives was discussed at the conference. The participants aimed at creating rules to regulate the effective occupation of colonial territories and to decide whether native consent was required or even could be required. Thus, a great part of the conference dealt with the question of the native character, which in turn defined the nature of their legal personality. In essence, natives were given a legal personality to justify various actions that were useful to the colonial powers, including the possibility to enter into treaties with native chiefs. ${ }^{101}$

The Berlin Conference changed the colonial ideology by introducing the language of humanitarianism. Humanitarianism as an ideology was combined with the language of trade and economics. Colonial policies could be justified with the combination of these two ideologies, humanitarianism and economics, "moral and material wellbeing". Trade became an essential part of the civilizing mission, as it was believed that economic growth was in the interest of the natives. At the same time, native welfare justified the development of a trade system based on European interests and the spread of trade into the entire African continent. Also the prohibition of slave trade was part of the increased emphasis on humanitarianism. ${ }^{102}$

The First World War changed the political situation in Europe. After the war the keeping of peace and a need for peaceful ways to resolve conflicts brought a

101 Ibid., 93-95. The signatory powers agreed that each of them could enlarge their territory through a treaty establishing a protectorate, as long as they informed the other powers of the treaty, giving them a chance to protest. Final Act of the Berlin Conference, February 26, 1885, articles 34-35. It was debated afterwards whether this signified the recognition of native sovereignty or a form of courtesy among the colonial powers, see Nuzzo, 'Colonial Law', sections 25-27; On the Berlin Conference, see Fisch, 'Africa as Res Nullius: The Berlin Conference and International Law'.

102 Anghie, Imperialism, Sovereignty, and the Making of International Law, 96-97. The concluding document of the Berlin Conference (Final Act of the Berlin Conference, February 26, 1885) on the Congo Free State outlined how the peaceful division of Africa would be amenable to trade and civilization. In article 6 , the signatory powers pledged to defend native peoples, end slavery and the slave trade and protect philanthropic work, teaching the natives and bringing them the advantages of civilization: "Article 6. Dispositions relatives à la protection des indigènes, des missionnaires et des voyageurs, ainsi qu'à la liberté religieuse. Toutes les Puissances exerçant des droits de souveraineté ou une influence dans lesdits territoires s'engagent à veiller à la conservation des populations indigènes et à l'amélioration de leurs conditions morales et matérielles d'existence et à concourir à la suppression de l'esclavage et surtout de la traite de noirs; elles protégeront et favoriseront, sans distinction de nationalités ni de cultes, toutes les institutions et entreprises religieuses, scientifiques ou charitables crées et organisées à ces fins ou tendant à instruire les indigènes et à leur faire comprendre et apprécier les avantages de la civilisation. Les missionnaires chrétiens, les savants, les explorateurs, leurs escortes, avoir et collections seront également l'objet d'une protection spéciale. La liberté de conscience et la tolérance religieuse sont expressément garanties aux indigènes comme aux nationaux et aux étrangers. Le libre et public exercice de tous les cultes, le droit d'ériger des édifices religieux et d'organiser des missions appartenant à tous les cultes ne seront soumis à aucune restriction ni entrave." 
need for new international institutions. ${ }^{103}$ The League of Nations provided a solution for such a need. ${ }^{104}$ The First World War also changed attitudes towards colonialism. The war had weakened the sense of moral superiority that had been such an important part of $19^{\text {th }}$ century colonialism. The Allies had justified the war by claiming that it had been fought for freedom and the Allied armies had included fighters from the colonies. ${ }^{105}$ However, anti-colonial movements were developing and there was also nationalist resistance in many colonies. US president Woodrow Wilson strongly argued for the self-determination of colonies. $\mathrm{He}$, as well as the American public, were opposed to colonialism in general and more specifically to the idea that war would be fought in order to gain colonies. ${ }^{106}$ Under the supervision of the League of Nations a new, more ethical colonial policy was emerging. ${ }^{107}$

The League of Nations also changed ideas on sovereignty. Firstly, as international law necessarily required the consent of states, it was easy for states to express their consent within the framework of an international organization. Secondly, while the League of Nations was generally dependent on the sovereign will of its members, in the mandates system it had a task to create sovereignty in new territories and define the preconditions thereof. ${ }^{108}$

Antony Anghie argues that international law was universalized by colonialism. For a long time, international law had been a European venture. Now, however, European international law was affecting the colonies as well and, as a consequence, necessarily changing its shape. One of the tasks of international law was to justify the continued existence of colonies. ${ }^{109}$

$19^{\text {th }}$ century lawyers started to emphasize positivism in their writings as a contrast to the naturalism of earlier centuries. Positivism left the non-European world entirely outside the realm of international law and from there they needed to win their acceptance back. ${ }^{110}$ According to Anghie, the positivists recreated the international legal system so that international law became the product of sovereign will. Simultaneously, international lawyers created a gap between

${ }^{103}$ See, however, Kennedy, 'The Move to Institutions'.

104 Anghie, Imperialism, Sovereignty, and the Making of International Law, 124-125.

105 Ibid., 138; Millot, on the other hand, claimed that a general ethos of national selfgovernance and rights had emerged as opposed to the claims of monarchs, and Wilson was merenn Hunt claims channelling these shared ideas. Millot, Les Mandats Internationaux; étude Sur L'application de L'article 22 Du Pacte de La Société Des Nations, 7-9.

106 Pedersen, The Guardiand, 23-24.

107 Anghie, Imperialiom, Sovereignty, and the Making of International Law, 137-139; Mazower, 'An International Civilization? Empire, Internationalism and the Crisis of the MidTwentieth Century', 559.

108 Anghie, Imperialism, Sovereignty, and the Making of International Law, 133.

${ }^{109}$ Ibid., 32.

${ }_{110}$ Martti Koskenniemi has criticized the emphasis placed on the supposed positivism of $19^{\text {th }}$ century jurists. Rather, he maintains, they "made constant use of arguments about morality or natural law". See Koskenniemi, The Gentle Civilizer of Nations, 131. 
Europe and rest of the world, between the civilized and the non-civilized. They created a technique, rules, with which this gap could be narrowed by dictating the conditions under which the non-European world could be in contact with Europe. To those who were believed to possess more civilization a network of conditions was created which would grant them a part in the international community. The less civilized had a system created for them that would bring them under the protection of Europe. ${ }^{111}$

International lawyers used the concept of society to overcome difficulties posed by the concept of sovereignty. The problem was that many entities existed that had the characteristics of sovereignty, but that the Europeans did not want to define as sovereign. This dilemma could be solved using the concept of society. A society could include those who accepted the principles of that society. Thus, international lawyers would create cultural characteristics that would help to define different groups and their relationship with the international community and international law.112 One important feature was territory, a criterion that would also be met by states that were not considered civilized. The criteria of society could be applied to such states. States outside Europe were not considered sovereign, as they were not part of the "family of nations". ${ }^{113}$ Anghie has distinguished non-European sovereignty from the sovereignty of European states by maintaining that the latter type of sovereignty set limitations to how much one could intervene in the inner affairs of a state, whereas the latter type of sovereignty meant that European states dictated to non-European states the criteria they needed to fulfil in order to become truly sovereign. Thus, the condition for sovereignty was that European states intervened in the inner affairs of these states and defined them as they pleased. Thus, sovereignty was moulded by a European worldview ${ }^{114}$ and international law became a science that created specific criteria to make such distinctions. ${ }^{115}$

The uncivilized could be left outside the realm of international law. Different criteria were created for different groups, the civilized and the uncivilized, and the civilized could determine which practices of the uncivilized were acceptable and what the real needs of the uncivilized were. ${ }^{116}$ After the First World War,

111 Anghie, Imperialism, Sovereignty, and the Making of International Law, 37; Anghie, 'Nationalism, Development and the Postcolonial State: The Legacies of the League of Nations', 454. See also Liszt, Das Völkerrecht. Systematisch Dargestellt, 2-5; Martitz, Kansainvälinen Oikeus, 1; Westlake, International Law, Part 1, Peace, 40-41; Lawrence, The Principles of International Law, 84; Lorimer, The Institutes of the Law of Nations, 101-103.

112 Anghie, Imperialism, Sovereignty, and the Making of International Law, 58-59.

113 Ibid., 49.

${ }^{114}$ Ibid., 102-104. Westlake, International Law, Part 1, Peace, 22.

115 Anghie, Imperialism, Sovereignty, and the Making of International Law, 48-52. Lorimer, The Institutes of the Law of Nations, 93-.

116 Donelly, 'Human Rights: A New Standard of Civilization?', 6; Gathii, 'International Law and Eurocentricity', 187; Koskenniemi, 'International Law in Europe: Between Tradition and Renewal', 191-192. 
positivist international law turned into pragmatism. Here, the American jurists played an important role. These lawyers criticized positivism by bringing political, social and economic questions into the sphere of international law. One of such lawyers was Manley Hudson, who studied these questions in the context of the mandates system and discussed the system from the perspective of the individual rights of the inhabitants of the mandates. ${ }^{117}$

The views of the pragmatists were apparent in the mandates system. ${ }^{118}$ Anghie describes the differences between the $19^{\text {th }}$ century ideas and the mandates system by maintaining that while $19^{\text {th }}$ century colonialism aimed at conquering, the mandates system aimed at protecting the natives. The positivists tried to leave non-Europeans outside the realm of international law, while the mandates system aimed at integrating them within the system. ${ }^{119}$ However, as I will discuss later in this thesis, the distinction was not as large, as there were many similarities between the mandates system and $19^{\text {th }}$ century thought, as Anghie also admits elsewhere. ${ }^{120}$ It was not easy for the victorious powers of World War I to relinquish the idea of annexing the former German colonies and Turkish territories. These territories were seen as spoils just as they had been for centuries. ${ }^{121}$ All colonial powers had interests in and plans for the territories, in both Africa and the Near East, and it required much persuading for them to give up these plans. ${ }^{122}$

The concept of "tutelage" and "trusteeship" had a long tradition in British colonial history. ${ }^{123}$ International law had recognized several methods through which non-Europeans had been brought under the control of colonial powers and to the realm of international law, including forceful colonizing by way of discovery, occupation, conquest or cession, ${ }^{124}$ and treaties between Europeans and native chiefs. ${ }^{125}$ Other methods included features similar to those in the mandates. Europeans had set a standard of civilization to determine how far a certain territory could be considered to be from European civilization. The rules that the Europeans would apply to these territories would depend on such

\footnotetext{
117 Hudson, 'The League of Nations and the Protection of the Inhabitants of Transferred Territories', 79-83.

118 Anghie, Imperialism, Sovereignty, and the Making of International Law, 118.

119 Ibid., 116.

${ }^{120}$ Ibid., 146; Yet, Wilhelm Grewe maintains that "the comprehensive legal importance of the concept of civilisation had almost vanished" by the $20^{\text {th }}$ century. Grewe, The Epochs of International Law, 582.

${ }^{121}$ Pedersen, The Guardians, 1, 19.

122 Ibid., 20-23.

123 Ibid., 24; Grant, 'The British Empire, International Government, and Human Rights', 574.

${ }^{124}$ Anghie, Imperialism, Sovereignty, and the Making of International Law, 82.

125 Ibid., 71-79.
} 
determination. ${ }^{126}$ Europeans could also make protectorate agreements in which the European states would take care of the interests of uncivilized states and protect them. Thus, the European states were able to control both the internal and external relationships of a state, while the latter formally had a native chief. For the Europeans, the protectorates had been a useful method of controlling nonEuropean states while being able to limit their own responsibility at the same time. ${ }^{127}$ Also, through the mandates system Europeans defined what the inhabitants of the mandated territories should be like in order to be integrated into the international community. Many believed that they could not be integrated at all.

One important concept for early $20^{\text {th }}$ century lawyers was that of consciousness, which had developed within the field of psychology. The result of positivist thinking had been that because of sovereignty and the requirement of consent, the interior of a state was left without outside supervision. International law could react only to external affairs of states. International lawyers saw that access to the interior of a state would revolutionize the entire field. According to Anghie, the meaning of human rights can be seen here, as they brought access to the interior, the consciousness, of a sovereign state. Anghie believes that the mandates system also brought international law and international institutions access to the interior of the mandatory states during the interwar period. ${ }^{128}$

\subsection{Earlier Scholarship on the Mandates}

Considering the scope and influence of the institution, the League of Nations mandates system has received surprisingly little attention from scholars. On the legal side, the work of Antony Anghie remains the most notable exception, but the general historical developments of the mandates are still understudied. The first studies on the mandates were published when the mandates were still in existence or immediately afterwards. ${ }^{129}$ These works were mostly descriptive and focused on the history of events.

Quincy Wright's thorough treatise on the mandates system was published in 1930 when the mandates had been in existence for a decade. ${ }^{130}$ The book was well received at the time. William Rappard, who had a long experience on the mandates system, complimented that "this remarkable treatise $\ldots$ is bound to

126 Gong, The Standard of 'Civilization' in International Society; Anghie, Imperialism, Sovereignty, and the Making of International Law, 84-85.

127 Anghie, Imperialism, Sovereignty, and the Making of International Law, 87-89.

${ }^{128}$ Ibid., 135.

129 Bentwich, The Mandates System; Chowdhuri, International Mandates and Trusteeship Systems; Hall, Mandates, Dependencies and Trusteeship; Wright, Mandates under the League of Nations.

${ }^{130}$ Wright, Mandates under the League of Nations. 
remain the standard work on mandates for many years to come". 131 As an American scholar, Wright could distance himself from his topic. Though he presents to the reader the origin of the system and the organization of the League in relation to the mandates and the methods of mandatory administration and supervision, he dedicates most of his attention to the "law of the mandates system" and especially the question of sovereignty. He also, quite exceptionally for his time, looks at the "rights" relating to the mandates from the perspectives of the different parties, including the rights of the League, ${ }^{132}$ the rights of the mandatories, ${ }^{133}$ the rights of the mandated peoples, ${ }^{134}$ and the rights of third states. ${ }^{135} \mathrm{He}$ maintained that due to their special status as not being under the sovereignty of any state but rather under the protection of the League, the people of the mandated territories enjoyed "rights under international law correlative to the duties imposed by the mandates upon the mandatories for their benefit". ${ }^{136} \mathrm{He}$ finishes his book by providing an array of scientific methods to measure progress in the mandates and native welfare. ${ }^{137}$ Wright, though one can consider him a humanitarian and a liberal, wrote as a representative of his generation. While he admitted that natives might have preferred to be left alone, he considered the possibility that their culture might entirely disappear "in continuous contact with the modern world" without expressing much regret. ${ }^{138}$ According to Wright, the most essential feature of the mandates system was the supervision it provided for: "Any one is a poor judge in his own case, and however it may try, a state has always found it difficult to visualize a subject people except from the standpoint of its own interests." $139 \mathrm{He}$ endorsed the idea of the extension of the principles behind the mandates, namely trusteeship, administration in the interests of natives, tutelage, "cultivation of a capacity for self-government" and international supervision. ${ }^{140}$

Norman Bentwich, Attorney-General of Palestine, also published his lectures on the mandates system in $1930 .{ }^{141} \mathrm{He}$ refers to his work as descriptive, due to his official position in one of the mandates. Thus, he refrains from discussing any controversial issues. However, he fails to hide certain liberal ideals in his book. His idea of the dual mandate is somewhat different from Lord Lugard's. ${ }^{142}$ Instead

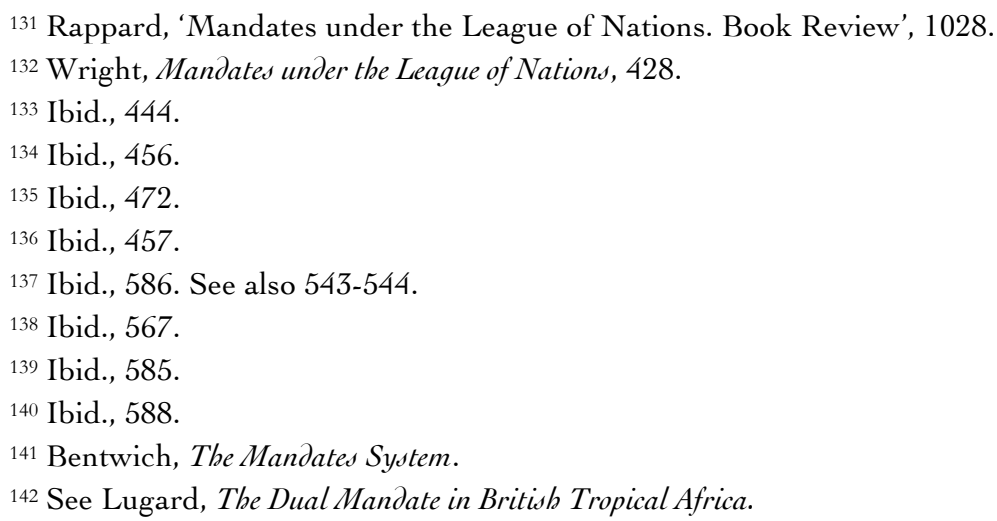


of referring to the (economic) benefits of the mandate to both the mandatories and the inhabitants of the territories, Bentwich speaks of a double trust on behalf of both the inhabitants and international society. ${ }^{143}$ The mandatory has an obligation and a responsibility, but no right as regards the mandated territories. ${ }^{144}$ According to Bentwich, the mandates changed the idea of sovereignty by the "definite purpose of preparing peoples under guardianship for self-government in the one case, and of carrying out, in the other case, a trust for the well-being of the inhabitants." 145

Duncan Hall studied the trusteeship system "as a phenomenon of the international frontier in relation to the working of the state system and the balance of power". ${ }^{146}$ Hall did not see the mandates as a product of humanitarianism, which he said played only a minor role, but as "by-products of the working of the state system of the world, of the political relations of the powers, and thus factors in the balance of power". ${ }^{147}$ Hall continued that concentrating on the African mandates showed the mandates system too much as a humanitarian phenomenon and omitted the importance of the former Turkish territories. ${ }^{148}$ Hall used the concept of the "International Frontier" to explain the birth of the mandates and the trust. He explained it through the shifts in empires, their territories, colonies, state rivalry, spheres of interest and the balance of power. ${ }^{149} \mathrm{He}$ described how the mandates are located in the frontiers of zones where the great powers make claims for territories. ${ }^{150}$

In International Mandates and Trusteeship Systems: A Comparative Study, Ramendra Chowdhuri studied the League of Nations mandates system and the United Nations trusteeship system from a comparative perspective. ${ }^{151} \mathrm{He}$ described the two systems from their birth to their actors, theories on sovereignty, and certain practical questions. He also dealt with the different forms of the development in the territories, discussing e.g. slavery, the position of women and forced labour under the topic "social development". ${ }^{152} \mathrm{He}$ only briefly referred to human rights in the trusteeships under the context of social advancement, but did not discuss what their meaning could be or how a mention of human rights would make trusteeships different from mandates. He did, however, mention the Universal Declaration of Human Rights and racial discrimination. However, he concluded that social and psychological conditions are so complex that the only

143 Ibid., 8.

144 Ibid., 17.

145 Ibid., 20.

${ }^{146}$ Hall, Mandates, Dependencies and Trusteeship, vii.

147 Ibid., 8.

148 Ibid., 11-12.

149 Ibid., 15.

150 Ibid., 16.

151 Chowdhuri, International Mandates and Trusteeship Systems.

152 Ibid., 283-290. 
means to affect such discrimination is education and understanding. ${ }^{153}$ One of his central points is that the idea of a "trust" is constantly changing. ${ }^{154} \mathrm{He}$ compared the starting point of both systems and saw them as parallel. Both were established after the war in a world where humanitarian ideas were in contradiction with practical realities, which would lead to compromises. In both cases, the welfare of non-self governing peoples was an important concern of the international community. According to Chowdhuri, "both systems rest on the foundation of enlightened self-interest". ${ }^{155}$ Both systems, moreover, were an innovation when one compares them to what had existed before and found the voluntary basis of both systems important. He draws a historical line with an aim to clarify how the changes in international trusteeship have occurred.156 He saw international accountability as the cornerstone of the trusteeship system. He noted that though there is no enforcement mechanism, the meaning of the public opinion was essential to the mandates. Thus, international accountability was for him the cornerstone of the mandates system. ${ }^{157} \mathrm{He}$ was concerned with the fact that no time limit was set in the trusteeships for the self-determination of the trusts. In his view, the inhabitants would have needed such a limit in order to be motivated to realize the changes and development required from them. Of the trusteeships he believed that they had led to the political, economic, social and civilizational development of the peoples, but that the end result depended on the sincerity of all parties. ${ }^{158}$

The resurgence of interest in the history of international law and empire has led to some new historical studies on the Mandates system. Michael Callahan's two-volume history of the mandates was published in 1999 and 2004.159 It was the first comprehensive research on the mandates system to appear after the decolonization period. However, Callahan has concentrated in his research on the African mandates and studied the mandates in the context of interwar colonial policies. He argues that the mandates system represented internationalization and changes in colonialism. According to him, the mandates changed the ideology of colonialism and had economic, political and cultural effects on both Europe and the inhabitants of the mandates. The mandates system not only reflected changes but created them as well. Some of these changes were unintended, but the system also aimed at solving problems relating to the traditional colonial idea of bringing

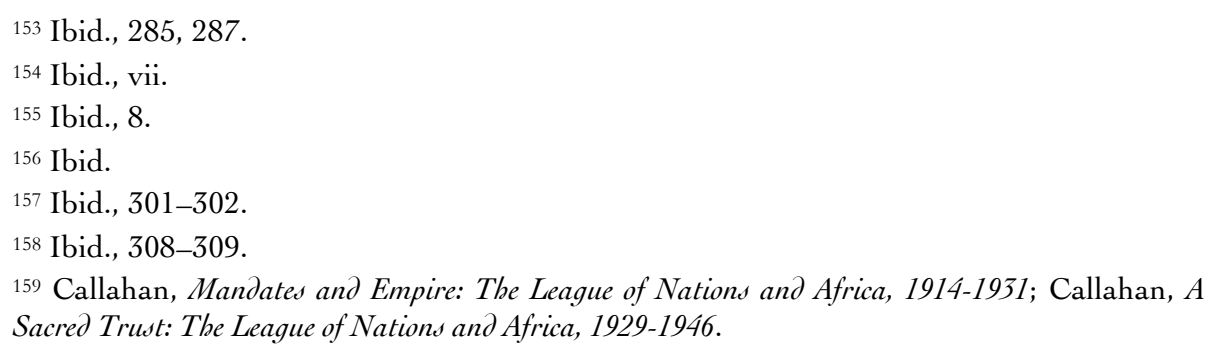


European institutions to Africa, the exploitation of African raw materials and the abuse of inhabitants. 160

Susan Pedersen's The Guardians: The League of Nations and the Crisio of Empire (2015) is the latest addition to the literature on the mandates. Susan Pedersen describes how the mandates system affected the imperialistic system in ways that its establishers could never have anticipated, by giving a voice to those different groups that had not had such a voice before. In the end, many started to question the position of the colonial system. ${ }^{161}$ What was new in the mandates was the machinery, international diplomacy, publicity and "talk", i.e. the public opinion that increasingly reacted to the publicity of the various deliberations at the League of Nations. At the least, the mandatory states were forced to say that they were governing the territories in a different manner than before. The mandates were part of a process of internationalization through the League of Nations, and the system worked within the tensions between the demands of the old imperialists and the demands of self-determination that came from the outside. Pedersen describes the "role of the League of Nations as an agent of geopolitical transformation". She argues that instead of being a failure, the mandates system and the League of Nations should be seen as more multifaceted and varied than before by examining how the different actors and objectives met, i.e. how imperial powers, the officers and rules of the League and local actors interacted. For Pedersen, the crucial change was the entry of Germany into the League, which gave the work of the mandates system a new dynamic. Realizing that it could have the old colonies back, Germany took to seeing that the promises of the establishing phase were fulfilled. Finally, Pedersen explains how the difficult years of the $30 \mathrm{~s}$, including the economic crisis and the withdrawal of Germany from the League affected the functioning of the mandates. ${ }^{162}$

The histories written on the mandates system are general histories aiming to describe or explain the mandates system on a general level, while Anghie has studied the position of the mandates in international law in general. In my research I am studying the mandates system as a case study, ${ }^{163}$ focusing on rights issues in the mandates system that have not been explored previously. Because the scale of the lacunae in scholarship, this study is limited to one issue, the use of rights language in the interwar era and beyond. Many issues are left for further research, such as the other activities of the League of Nations, the study of the minority questions more broadly (especially the petitions system), the various

${ }^{160}$ Callahan, Mandates and Empire: The League of Nations and Africa, 1914-1931, 7.

161 Pedersen, The Guardians, 4, 13, 403-405.

162 Ibid., 10-12.

163 See e.g. Marie-Bénédicte Dembour, who has studied the European Human Rights system as a case study in her research on the different approaches to and critiques of human rights. She maintains that her focus on the European Court of Human Rights has been arbitrary and that she could have similarly studied any other human rights institution to make her point. Dembour, Who Believes in Human Rights?, 8-9. 
committees of the League (particularly on slavery and women's issues) and the International Labour Organization (ILO). As I will show in the section on women's issues (3.5), discussions similar to those held at the League of Nations would continue in the United Nations era as well. On the other hand, the Slavery Commission and the Permanent Mandates Commission had members in common, and thus it is likely that questions regarding slaves would be discussed in a similar fashion in both instances. 


\section{The League of Nations and the Establishment of the Mandates System}

\subsection{Establishing the Mandates}

\subsubsection{Drafting the Mandates System}

The purpose of this section is to explore the drafting process of the mandates system before, during and after the negotiations of the Versailles Peace Treaty and the League of Nations Covenant. The central issue was the consolidation of Wilson's Fourteen Points and the principle of self-determination and the continuation of the practices of colonialism. The framers grappled with what was to be done with the former colonies of the Central Powers. Due to Wilson's ideals, annexation was out of the question, but at the same time the territories were not considered ready for independence. The formulation of the mandates system was a contentious process in which the plans were changed numerous times. Central figures in this were Wilson and Jan Smuts, who sought to seek a balance between liberal ideals and vocal demands for annexation. While the narrative of the mandate negotiations has been told by eyewitnesses like David Hunter Miller and most recently by the historian Susan Pedersen, this section seeks to follow the formation of the legal principles of self-determination and petition within the process. Though the principle of non-annexation was based on humanitarian ideals as well as socialist policies advocated by the British Labour Party and discussed in the February 1918 inter-Allied Labour and Socialist Conference, the result was a legal document interpreted by international lawyers. ${ }^{1}$

In Britain, imperialism as such was not frowned upon. Quite the contrary, Britain wanted to become a moral leader in colonial policies and it was widely believed that the mandatory system replicated the British colonial ideal. The British had seen themselves as the protectors of natives from the misdeeds of bad colonial masters, such as Portugal and France. It was the task of the British to help small nations and their inhabitants. ${ }^{2}$ Initially Britain was the only country to support Wilson's ideas, acting as an intermediary between the Americans and the rest. ${ }^{3}$ However, Michael Callahan has argued that the British gave the impression of supporting Wilson, while at the same time they did not believe that the idea of mandates would apply to colonies in British hands. ${ }^{4}$ Yet, as the American historian Susan Pedersen has described, Britain easily accepted a third element (liberal internationalism) to add to its dual attitude towards its colonies, imperial

\footnotetext{
${ }^{1}$ Chowdhuri, International Mandates and Trusteeship Systems, 39.

${ }^{2}$ Pedersen, The Guardians, 20-25.

3 Ibid., 28.

${ }^{4}$ Callahan, Mandates and Empire: The League of Nations and Africa, 1914-1931, 28.
} 
humanitarianism and imperial expansionism. ${ }^{5}$ British Prime Minister Lloyd George and Lord Robert Cecil believed that the mandates would set the standard for the colonies everywhere, British standards instead of those of France and Portugal, for example. The British Colonial Secretary, Viscount Alfred Milner, on the other hand, saw the mandates as a mechanism for the universalization of British norms and practices. ${ }^{6}$

France was initially strongly opposed to the idea of mandates and internationalism and would have been glad to see the whole idea fail.7 Georges Clemenceau, the French Prime Minister, was obsessed with the idea of punishing Germany. The French wanted to see the former German colonies in new hands and were reluctant to accept the idea of external control. ${ }^{8}$ In the Near East France had high hopes of gaining Syria and preferably also Palestine as French colonies. ${ }^{9}$ Particularly important was also the question of African soldiers. France wanted to use soldiers from its African colonies, but this would have been prohibited in the mandates. The question of soldiers became decisive to French acceptance of the mandates system, as she was promised that the terms of the mandates did not prevent her from using African armies to defend the mandated territories. ${ }^{10}$

Popular opinion had turned against new colonies by the end of the war. ${ }^{11}$ President Wilson strongly supported the principle of non-annexation. In the UK and in France, however, there was a strong internal division on the reaction to the fate of the former Turkish and German colonies. In both countries, the labour and socialist parties (in Britain also the liberals) supported international supervision, whereas in Britain there was strong criticism from the conservatives towards the new plans and in France Prime Minister Clemenceau and Minister of Foreign Affairs Pichon supported direct annexation. An Inter-Allied Labour and Socialist Conference was held in London in February 1918, which proposed for "all German and Turkish colonies a system of international supervision which would respect 'national sovereignty' but at the same time safeguard the interests of the indigenous inhabitants and preserve the open door".12 British premier Lloyd George supported the principle of national self-determination with the understanding that "the inhabitants should be placed under the control of an

\footnotetext{
${ }^{5}$ Pedersen, The Guardians, 27.

${ }^{6}$ Ibid., 28-30.

${ }^{7}$ Callahan, Mandates and Empire: The League of Nations and Africa, 1914-1931, 29; Dimier, 'On Good Colonial Government: Lessons from the League of Nations', 284.

${ }^{8}$ Pedersen, The Guardians, 33; Callahan, Mandates and Empire: The League of Nations and Africa, 1914-1931, 29; See also Crozier, 'The Establishment of the Mandates System, 1919/1925: Some Problems Created by the Paris Peace Conference', 493.

9 Pedersen, The Guardians, 22.

${ }^{10}$ Ibid., 29; Callahan, Mandates and Empire: The League of Nations and Africa, 1914-1931, 33.

11 Koskenniemi, The Gentle Civilizer of Nations, 171; Haas, 'The Reconciliation of Conflicting Colonial Policy Aims (mandates)', 523.

${ }^{12}$ Chowdhuri, International Mandates and Trusteeship Systems, 39.
} 
administration acceptable to themselves'”. ${ }^{13}$ The Dominions, South Africa, New Zealand and Australia, on the other hand, believed in the right to annex the neighbouring German territories for themselves. ${ }^{14}$ As Lloyd George explained in Paris in 1919, the people in the Dominions were behind their governments on the mandate question: "These gentlemen were not enamoured with the system." 15 In Britain many, including Lloyd George, however believed that the empire was already large enough. ${ }^{16}$

The different participants of the Paris Peace Conference had varied ideas on the fate of the territories that had been proposed as mandates and how they were to be administered. ${ }^{17}$ At the peace negotiations "discussions ... were heated and violent", as Miller reported from the drafting meetings. ${ }^{18}$

The United States and the United Kingdom agreed on the necessity of nonannexation of the territories, though there were differences in the implementation of this idea. ${ }^{19}$ The United States believed that it was time to end the colonial era and saw itself as a leader in this change. Also in Britain the idea of outright annexation was mainly rejected. ${ }^{20}$ Therefore of all mandatory nations it was easiest for the British to reconcile their ideas with the Americans. ${ }^{21}$ The British policy, at least officially, was that it did not want more colonies, British policy makers realizing that it had nothing to gain from new colonies economically or politically. Thus Britain supported the US in the plans to find a new solution for the mandated territories. When promoting his plans, Wilson emphasized that the interest and benefit of the people living in the territories would have equal weight to the government claims. He also wanted the Turkish territories to have an "absolutely unmolested opportunity of autonomous development."22

The British Dominions, South Africa, New Zealand and Australia, had several reasons for their demands of annexation of the German colonies. Firstly, there was the need of compensation for the cost and losses to the Dominions in World War I: "The Dominions entered into this war ... because the Empire, of which they were a part, was fighting for a great cause - fighting for its honour for humanity - for civilisation, in order to keep faith with its Allies, and to defend

\footnotetext{
${ }^{13}$ Ibid., 39-40.

${ }^{14}$ Ibid., 43-44.

${ }_{15}^{15}$ Miller, Drafting the Covenant, Vol. 2, 198.

${ }^{16}$ Chowdhuri, International Mandates and Trusteeship Systems, 43-44.

${ }^{17}$ Knoll, The Legal Status of Territories Subject to Administration by International Organisations, 58.

${ }_{18}$ Miller, Drafting of the Covenant, Vol. 1, 105.

${ }^{19}$ Chowdhuri, International Mandates and Trusteeship Systems, 45.

${ }^{20}$ Miller, Drafting of the Covenant, Vol. 1, 104.

${ }^{21}$ Pedersen, The Guardians, 28.

22 Chowdhuri, International Mandates and Trusteeship Systems, 45. See also Crozier, 'The Establishment of the Mandates System, 1919/1925: Some Problems Created by the Paris Peace Conference', 484-85.
} 
the smaller nations." ${ }^{23}$ Secondly, there were security considerations and thirdly, in the Dominions' view annexation would also have been in the interests of natives. ${ }^{24}$ New Zealand Prime Minister William Massey maintained that direct annexation would speed up the development of the territories and would thus be better for all concerned. Annexation would also in his view help spread the principles of Christianity, "necessary for the welfare of all nations". ${ }^{25}$ Australian Prime Minister William Hughes noted that like his colleagues from New Zealand and South Africa they were in favour of direct control, "'annexation', to put it bluntly, as Massey noted". ${ }^{26}$

Of the demands for annexation, Wilson was adamant that "the world would not accept such action". "Principles of non-annexation and international accountability, consent of the governed in the Turkish dependencies" must prevail over the "recognition of the occupying Powers as Mandatories and allocation of the Mandates by the Allied and Associated Powers instead of the League of Nations." 27

For Britain it took some time to persuade the Dominions. In the end, the Dominions were prepared to accept the mandates as a compromise. They strongly demanded the three different classes of mandates, which were later to become the A, B and C mandates. British Prime Minister Lloyd George maintained that the system to be applied to "countries where the population was civilized but not yet organized" needed to be different from those that were to be applied to "cannibal colonies, where people were eating each other". ${ }^{28}$ The Dominions were not alone in their demands for annexation, as the Japanese also demanded annexation. ${ }^{29}$ The French, for their part, wanted to annex Togoland and the Cameroons "to ensure the effective protection and development of the natives 'towards a higher plane of civilization"'.30

There were differing views on how the administration of the mandates would be arranged. ${ }^{31}$ Initially, Wilson supported supervision and control by the League. Again, he met fierce opposition from the Dominions. Both Hughes of Australia and Smuts of South Africa claimed that international administration would lead to "confusion". ${ }^{2}$ "The inhabitants of the territory are either confused or if they are sufficiently developed, make use of these differences by playing one set of nations

\footnotetext{
${ }^{23}$ Miller, Drafting the Covenant, Vol. 2, 207.

${ }^{24}$ Chowdhuri, International Mandates and Trusteeship Systems, 46.

${ }^{25}$ Miller, Drafting the Covenant, Vol. 2, 206.

${ }^{26}$ Cited in ibid., Vol. 2, 209 and 214.

${ }^{27}$ Chowdhuri, International Mandates and Trusteeship Systems, 47.

${ }^{28}$ Miller, Drafting the Covenant, Vol. 2, 195.

${ }^{29}$ Chowdhuri, International Mandates and Trusteeship Systems, 46.

30 Ibid., 47.

${ }^{31}$ See Dimier, 'On Good Colonial Government: Lessons from the League of Nations'.

${ }^{32}$ Chowdhuri, International Mandates and Trusteeship Systems, 56-57.
} 
off against the other", as Smuts put it. ${ }^{33}$ In this matter Wilson could not expect support from the United Kingdom. Lloyd George noted that there was an agreement that there would be no indirect administration for the former colonies. Faced with such arguments direct international control was rejected and the principle of single Mandatory administration "on behalf of the League" was included in the Covenant. Also Germany had demanded international administration. ${ }^{34}$

The creation of the mandates system may be credited to two very different characters, US president Woodrow Wilson and South African general Jan Smuts. Both were very conflicted personalities, possessing at the same time great idealism and a tendency to support policies that were later denounced as racist. Wilson's well-known programme of fourteen points called for the reorganization of world order, and the peaceful resolution of conflicts was first entered as part of the agreement of armistice and then to the peace conference. Though Wilson's initial policy had been to keep the US out of war and to concentrate on domestic matters, he changed policy after the German submarine warfare had caused popular outrage. Before election as president, Wilson was a lawyer who had a long career in both academia, especially in Princeton, and in politics as the Democratic governor of New Jersey. A progressive politician, Wilson's interest in statesmanship was both academic and practical. Despite his reputation as an idealist with regard to international relations, critics had remarked that in practice Wilson disregarded his principles such as the idea of national self-determination by enforcing military US interests in South America. His record on race is similarly mixed, because he supported segregation and saw US slavery through a paternalistic idealism. ${ }^{35}$ Wilson's influence in the peace process, though crucial, suffered from his deteriorating health and a lack of domestic support. ${ }^{36}$ The support for Wilson was due to the Americans' unwillingness to wage a war for imperialistic aims. Wilson's promise was to give peace without the establishment of new colonies and to reform European imperialism. ${ }^{37}$ The United States, however, failed to ratify the Versailles Treaty due to domestic concerns. ${ }^{38}$

The second central character in the establishment of the mandates system was Jan Smuts. Smuts had at that point a long career behind him in South Africa,

\footnotetext{
${ }^{33}$ Ibid.

${ }^{34}$ Ibid.; Crozier, 'The Establishment of the Mandates System, 1919/1925: Some Problems Created by the Paris Peace Conference', 491.

${ }^{35}$ See e.g. Blumenthal, 'Woodrow Wilson and the Race Question'.

36 The life of Wilson has been told in numerous biographies, such as Cooper, Woodrow Wilson; Cooper, Breaking the Heart of the World: Woodrow Wilson and the Fight for the League of Nations; Knock, To End All Wars: Woodrow Wilson and the Quest for a New World Order.

${ }^{37}$ Cooper, Woodrow Wilson; Cooper, Breaking the Heart of the World: Woodrow Wilson and the Fight for the League of Nations.

38 Pedersen, The Guardians, 35. On problems relating to the absence of the US in the League, see Rappard, 'The Evolution of the League of Nations', 796-797.
} 
where he had been born to an Afrikaner family. Originally a lawyer educated in Cambridge, Smuts had returned to South Africa as conflicts between the Boers and the British were rising. He participated in the Boer War as a field commander and went into politics after the war, becoming an advocate for the Boers and a unified South Africa. During the World War, Smuts had commanded the troops that conquered the German South West African colony, the current Namibia. He went on to join the British war effort in Europe and to command troops in the war, surfacing after the war as one of the key figures in the establishment of the League of Nations. Smuts supported a strong Commonwealth of Nations that would balance the interests of great and smaller powers on the world stage. Smuts's position at Versailles was a delicate one, he was a representative of the British Dominions, who had insisted in the face of opposition from British politicians that they would be present in the negotiations as equals. Smuts wrote a memorandum on the League that was read by Wilson, who was enthusiastic about the idealistic vision. Smuts had proposed the League as the solution to the national problem and formulated the outline of the mandates system, which was equally taken on by Wilson. ${ }^{39}$ Like Wilson, Smuts had a far less idealistic side in domestic politics, where he was a supporter of segregation and the dominance of Afrikaners in South African politics. ${ }^{40}$ Perhaps as a consequence of Smuts's personal involvement and the impact it had in South Africa, Smuts did not think that the mandates system should be universal. For example, the policy of non-annexation did not apply to German colonies, according to Smuts. ${ }^{41}$ Thus the position of the German South-West African colony, conquered by South Africa, was not at all clear.

During the drafting period Britain was led by Liberal Prime Minister Lloyd George, who was known for his progressive ideas, such as the welfare system. During the process Lloyd George sought to moderate nationalist views of participants. He accepted the idea of a mandates system in principle, but was also willing to consent to the demands of the Dominions. ${ }^{42}$ As the British noticed that Wilson was not planning to give in, they turned to their second plan, where the mandates would be divided into three groups. The first group contained those mandates that needed only assistance, the second group those where the mandatories would have sovereign rights, and the third group would take into account the annexationist demands of the Dominions. Lloyd George saw the role of the League of Nations to be relevant only if the mandatories misused their

\footnotetext{
${ }^{39}$ Smuts, The League of Nations: A Practical Suggestion. See also Curry, 'Woodrow Wilson, Jan Smuts, and the Versailles Settlement', 970.

${ }^{40}$ On the idealization of Smuts, see Crafford, Jan Smuts, especially 140-142 on the idea of mandates.

${ }^{41}$ Miller, Drafting of the Covenant, Vol. 1, 36.

42 Egerton describes Lloyd George's approach to the establishing of the League of Nations as "conservative internationalism". Egerton, "The Lloyd George Government and the Creation of the League of Nations', 443.
} 
power. Wilson, however, thought that this was not enough. The compromise was found by a British draft that would give the League more power on the mandates according to Wilson's wishes. ${ }^{43}$

The idea of an internationalized regime for the German and Turkish colonies was presented in different contexts in the years 1917-1918, when it had become clear that the war would be won by the Allied powers. Different proposals were drafted for the post-war eventualities, but much depended on the outcomes of the peace negotiations.

The founding of the League of Nations and the Paris Peace Conference were closely intertwined, as the Covenant of the League and consequently the Covenant's Article 22 concerning the mandates were drafted during the Paris Conference. The conference took place in 1919-1920 at Versailles and thirty-two states participated in the negotiations. ${ }^{44}$ The Paris Conference was initially a meeting to set the terms for the peace treaty with the Central Powers but grew into a massive reorganization of the global order where the mandates system was but a small part.

A draft covenant of the League and its earlier article 19 on the mandates was approved by the Supreme Council of the Allied powers in February 1919, only a month after the beginning of the peace conference. Its contents had already been agreed upon by the Council of Ten, the representatives of the main Allied powers, in January 30, 1919. The article concerning the mandates received its final form now as Article 22 of the League Covenant on April $25^{\text {th }}, 1919.45$

The first drafts of the League Covenant, the Draft Convention of Lord Phillimore's Committee to the British Government (March 2, 1918), Colonel House's draft to President Wilson (July 16, 1918) and Wilson's own first draft (late summer 1918) did not contain any mentions of mandates. However, according to the notes of geographer Isaiah Bowman, Wilson had on December 10, 1918 explained the idea of declaring Germany's former colonies the "common property of the League of Nations and administered by small nations". ${ }^{46}$

The first League Covenant draft to refer to the mandates was articles 2-9 of the Smuts plan of December 16, 1918. According to Smuts, the fundamental principles that will guide in the establishment of the League were "no annexations, and the self-determination of nations". ${ }^{47}$ More concretely, he recommended to the "peoples and territories formerly belonging to Russia, Austria and Turkey ... no annexation of any of these territories to any of the victorious Powers, and secondly, that in the future government of these territories and peoples the rule of self-determination, or the consent of the governed to their form of government,

43 Callahan, Mandates and Empire: The League of Nations and Africa, 1914-1931, 31-32.

${ }^{44}$ Northedge, The League of Nations: Its Life and Times 1920-1946; League of Nations, The Mandates System: Origin, Principles, Application, 13-.

${ }^{45}$ League of Nations, The Mandates System: Origin, Principles, Application, 18.

${ }^{46}$ Cited in Miller, Drafting of the Covenant, Vol. 1, 43.

${ }^{47}$ Smuts, The League of Nations: A Practical Suggestion, 12. 
shall be fairly and reasonably applied". 48 This idea was realized only partially, as in the end the mandates did not extend to Russian and Austrian former territories. Instead, German colonies in Africa and the Pacific were only added in a later plan by Wilson. Of these, Smuts had famously written "the German colonies in the Pacific and Africa are inhabited by barbarians, who not only cannot possibly govern themselves, but to whom it would be impracticable to apply any ideas of political self-determination in the European sense". ${ }^{49}$ Even later, when such colonies would become mandates, South Africa would never accept that the principle of non-annexation applied to them as well, which led to an ongoing conflict with the League and later the United Nations on the last mandate to become independent, South West Africa. On the other hand, Smuts was inspired by President Wilson's Fourteen Points, ${ }^{50}$ to suggest the disposal of the former German colonies. Clause 4 recommended that "authority, control, or administration", unless the peoples had their own self-determined authority, "shall be the exclusive function of and shall be vested in the League of Nations and exercised by or on behalf of it".51 If the League were to delegate its authority, control or administration to another State as its "agent or mandatary", such an "agent or mandatary", if possible "shall be nominated or approved by the autonomous people or territory". ${ }^{52}$ Smuts assumed that in most cases the mandatory would be chosen by the people "on historic grounds", determined by "old ties of acquaintance or friendship". ${ }^{53}$ However, where an autonomous regime was not yet possible (he mentioned Palestine and Armenia as examples), the League should nevertheless try to find out the wishes of the people and select a mandatory accordingly. ${ }^{54}$ "The mandatary State should look upon its position as a great trust and honour, not as an office of profit or a position of private advantage for it or its nationals." ${ }_{55}$ According to Smuts's plan, there would be separate Acts or Charters, in which the details of the mandates would be stipulated and which would vary in the different territories. "The delegation of certain powers to the mandatary State must not, however, be looked upon as in any way impairing the ultimate authority and control of the League... " 56

\footnotetext{
48 Ibid., 15.

${ }^{49}$ Ibid.

${ }^{50}$ Point five: "A free, open-minded, and absolutely impartial adjustment of all colonial claims, based upon a strict observance of the principle that in determining all such questions of sovereignty the interests of the populations concerned must have equal weight with the equitable claims of the government whose title is to be determined."

${ }^{51}$ Smuts, The League of Nations: A Practical Suggestion, 17.

52 Ibid., 21.

53 Ibid., 20.

${ }^{54}$ Ibid., 20-21.

55 Ibid., 21.

56 Ibid., 21-22.
} 
The so-called Cecil Plan of January 14, 1919 by Lord Robert Cecil, head of the League of Nations section of the British delegation and president of the League of Nations Union, did not pick up on Smuts's suggestion. ${ }^{57}$ However, Wilson in his second draft (January 10, 1919, also sometimes called Wilson's First Paris Draft) did. He added a supplementary agreement to his draft, which included also the former colonies of Germany that Smuts had not included in his plan. Wilson also added the possibility of substituting one mandatory for another. Wilson still included the former territories of Austria-Hungary in his plan. According to him, "the League of Nations shall be regarded as the residuary trustee with sovereign right of ultimate disposal or of continued administration in accordance with certain fundamental principles hereinafter set forth". The principles mentioned were no annexation, that self-determination or the consent of the governed to their form of government shall be "fairly and reasonably" applied, and that the administration and economic development shall be "based primarily upon the well-considered interests of the people themselves". ${ }^{58}$ The clause on the League's authority and separate agreements remained as Smuts had drafted them. The article also included a reference to the "open door" policy ${ }^{59}$ for League members.

Cecil made a new draft on January 19, 1919 after which Wilson prepared a Third Draft on January 20, 1919, after having received comments from the American delegation. The first parts of the Article on mandates were similar to Wilson's earlier draft, but he added more detail to the special agreements noting that they would be drafted by the Executive Council. He also added a paragraph on the distribution of expenses, and another lengthy one where he clearly stated his commitment to the principle of self-determination:

The object of all such tutelary oversight and administration on the part of the League of Nations shall be to build up in as short a time as possible out of the people or territory under its guardianship a political unit which can take charge of its own affairs, determine its own connection, and choose its own policies. The League may at any time release such a people or territory from tutelage and consent to its being set up as an independent unit. It shall also be the right and privilege of any people or territory to petition the League to take such action, and upon such petition being made it shall be the duty of the League to take the petition under full and friendly consideration with a view to determining the best interests of the

\footnotetext{
57 Miller, Drafting the Covenant, Vol. 2, 61. Cecil was an ardent internationalist who believed that the League and international co-operation would be the cure for international difficulties and animosities. See Cecil, The New Outlook.

58 Wilson's Second Draft or First Paris Draft, January 10, 1919, supplementary agreement I, cited in Miller, Drafting the Covenant, Vol. 2, 65.

${ }^{59}$ Gerig, The Open Door and the Mandates System.
} 
people or territory in question in view of all the circumstances of their situation and development. ${ }^{60}$

Jan Smuts drafted a resolution with a three-level division of what he now called mandates, including the future A mandates, i.e. "certain communities formerly belonging to the Turkish Empire" [he included also Armenia and Kurdestan], those Central African peoples that would become inhabitants of the B mandates, and the territories that "can be best administered under the laws of the mandatory states as integral portions thereof", later the C mandates. ${ }^{61}$

The same ideas as were in the Smuts's resolution also found their way into a British draft resolution from January 24, 1919. However, the British draft resolution spoke of '“assisted states' which in consequence of the late war are to attain their independence, [and] shall be entitled to such assistance as they may desire for the purpose of securing peace, order and good government for the population of those states..." and "'vested territories' which in consequence of the late war are to be transferred to any states [and] shall be held by such states upon trust to afford to their inhabitants peace, order and good government". ${ }^{62}$ The description of the vested territories included a list of prohibited practices, including slavery and forced labour. Likewise, the vested territories and assisted states would include freedom of conscience as well as a mention of equal economic opportunities and an open door policy for all League members. The British draft also included clearer ideas on sovereignty, as the final articles on mandates would. In the case of vested territories, "the States placed in charge thereof shall discharge all duties and responsibilities and be invested with all powers and rights of a sovereign government, but they shall report annually to the League of Nations on all matters relating to the discharge of their obligations under this convention". As regards assisted states, the assisting states only had the "powers, rights, duties, and responsibilities as shall be given to them by any agreements with the Assisted States ...". ${ }^{63}$ The Council of Ten prepared a resolution on January 30, 1919, which was based on a resolution drafted by Smuts. ${ }^{64}$ This resolution would resemble to a large extent the final version of the mandates.

The mentions of the right to appeal and the special acts with which each mandate would be separately defined and that had existed in Smuts's original plan and Wilson's drafts did not find their way into the resolution of the Council of Ten or the final Article $22 .{ }^{65}$ On the other hand, the Council of Ten resolution included

\footnotetext{
${ }^{60}$ Wilson's Third Draft or Second Paris Draft, January 20, 1919, supplementary agreement III, cited in Miller, Drafting the Covenant, Vol. 2, 98.

${ }^{61}$ Miller, Drafting of the Covenant, Vol. 1, 110.

62 Ibid., Vol. 1, 106.

${ }^{63}$ Ibid., Vol. 1, 107.

${ }^{64}$ Ibid., Vol. 1, 105.

${ }^{65}$ Ibid., Vol. 1, 111.
} 
introductory paragraphs on the reasons for the mandates, which were omitted from the final version. ${ }^{66}$

Wilson prepared a fourth draft on February 2, 1919, ${ }^{67}$ where two paragraphs were added to the Council of Ten resolution. One authorized the League to issue mandates and hear petitions and the other stated as the object of mandates to "build up in as short a time as possible out of the people or territory under its guardianship a political unit which can take charge of its own affairs, determine its own connections, and choose its own policies". ${ }^{68}$

The mandates article took its final form during the meetings of the Commission of the League of Nations, starting on February 3, 1919, in Paris. The draft upon which the Commission worked was not Wilson's but the Hurst-Miller draft by the legal advisers of the British and American delegations. ${ }^{69}$ As the HurstMiller draft was very brief, Smuts introduced a draft based on the resolution of the Council of Ten from January 30.

The early plans of Article 22 included a right to petition (or appeal, as it was worded in Wilson's and Smuts's plans), as existed in British colonies. For instance, Wilson's second Paris draft stated that "[the Executive Council], which shall also reserve to the people of any such territory or governmental unit the right to appeal to the League for the redress or correction of any breach of the mandate by the mandatory State or agency or for the substitution of some other State or agency, as mandatory". ${ }^{70}$ Wilson's third Paris draft still included the right to petition. However, in this draft a different wording was used. The proposed right was to petition to the League to release the territory from its mandatory, and to grant it a status as an independent unit. ${ }^{71}$ The question of whether the consent of the governed peoples was required to set up an administration was also omitted from the final version of Article 22.72

The mandates consisted of the former Turkish territories and German colonies. Article 22 of the Covenant of the League of Nations does not mention which of the territories were included in this distinction nor who was to become responsible for their administration. The details were later to be described in individual treaties for each of the mandates. The German and Turkish colonies were initially handed over to the Allied powers. The Supreme Council of the Allied powers selected the mandatory powers. ${ }^{73}$

The territories that were to be added to the mandates system varied throughout the plans. Smuts did not include the former German African and

\footnotetext{
${ }^{66}$ Ibid., Vol. 1, 109.

${ }^{67}$ Cited in Miller, Drafting the Covenant, Vol. 2, 145.

${ }_{68}$ Wright, Mandates under the League of Nations, 32.

${ }^{69}$ Ibid.

${ }^{70}$ Miller, Drafting the Covenant, Vol. 2, 104.

${ }^{71}$ Wilson's 3rd Paris draft, supplementary agreement III, in ibid., Vol. 2, 153.

72 Ibid., Vol. 2, 87.

${ }^{73}$ League of Nations, The Mandates System: Origin, Principles, Application, 19.
} 
Pacific colonies in the mandates. ${ }^{74}$ However, David Hunter Miller, a legal adviser to the American delegation to the League commission, states in his account of the League Covenant drafting negotiations that all agreed in the necessity of Germany losing its colonies. ${ }^{75}$

Of the former Turkish territories, Armenia was initially to be included in the mandates. It was believed that Armenia needed internationalized administration for the protection of the Armenians. The mandates system would have saved the Armenians "from a brutal fate". As Lloyd George put it, "somebody had to be there to protect the Armenians, and to keep the tribes and sects in Lebanon from cutting each other's throats". ${ }^{76}$ These were direct references to the horrific events during the war, when hundreds of thousands of ethnic Armenians died from mass killings, starvation and forced marches in the so-called Armenian genocide. ${ }^{77}$

In the end, the result was the division of mandates into three classes. The A mandates were comprised of territories that had been part of the Turkish Empire. These communities were recognized provisionally as independent nations, though only $\mathrm{Iraq}^{78}$ gained actual independence during the existence of the mandates. The three other $\mathrm{A}$ mandates were Transjordan ${ }^{79}$ and Palestine, ${ }^{80}$ administered by Britain, and the joint mandate of Syria ${ }^{81}$ and Lebanon, administered by France. The $\mathrm{B}$ mandates were all situated in Central Africa, and comprised Togoland (British and French), the Cameroons (British and French), Ruanda-Urundi (Belgium) and Tanganyika (Britain). Here the inhabitants were seen to be at such "a stage that the Mandatory must be responsible for the administration of the territory". The $\mathrm{C}$ mandates were a compromise between annexation and nonannexation. ${ }^{82}$ The $\mathrm{C}$ mandates included South- West Africa and the Pacific islands of Nauru, New Guinea and Samoa (administered by the Dominions) and the Islands under Japanese mandate, the South Sea Islands (Islands north of the

${ }^{74}$ Smuts, The League of Nations: A Practical Suggestion, 15.

${ }^{75}$ Miller, Drafting of the Covenant, Vol. 1, 105.

${ }^{76}$ Ibid., Vol. 1, 115.

${ }_{77}$ Bass, Freedom's Battle, 315-326.

78 Treaty between Great Britain and Iraq (1922); 13 January 1926 revised treaty according to which the question of Iraq's admission to the League would be examined at successive intervals of four years. Chowdhuri, International Mandates and Trusteeship Systems, 104.

79 Transjordan: Anglo-Jordan treaty of 20 February 1928. Jordan gained independence only on March 22, 1946. Ibid., 106.

${ }^{80}$ Palestine: Balfour Declaration of 2 November 1917. "The purpose of this Declaration was to rally the support of the World Jewry to the cause of the Allies against the enemy Powers so as to secure Jewish financial aid." ... "Thus, the Jewish national home in Palestine was, at its inception, a part of the British concept of imperial strategy." ... "The subsequent British policy was ambiguous." Ibid.

${ }^{81}$ Independence treaty of Syria signed in September 9, 1936 but never ratified by the French, who complained it did not provide "for adequate guarantees for the minorities, scattered and compact". Ibid., 104.

82 Ibid., 43-44. 
equator, including the modern-day Palau, Northern Mariana Islands, Federated States of Micronesia, and the Marshall Islands). These mandates were to be administered "under the laws of the Mandatory as integral portions of its territory". 83

In conclusion, the drafting process of the mandates system was a convoluted negotiation during the Paris Peace Conference. The mandates were born as a side product of the meeting of Wilsonian internationalism and colonial practices. The underlining question was what to do with the former colonies of the Central Powers, which were transferred to the victorious powers. Having ruled out annexation during the war, the administration of the former colonies was a practical problem that needed to be solved. The central characters were Wilson and Smuts, who oversaw that the details of the system were hammered out in numerous drafts. The victorious Allied powers were by no means unanimous in their opinions, some favouring annexation and only through lengthy negotiations would they accede to the plan. An internationalized system of governance was set up, three different categories of mandated areas were determined based mostly on levels of development and civilization as understood by the Allied powers and a system of oversight was established. That Wilson's idea of international governance would produce something like the mandates system was a result of political expediency as British popular opinion was soundly against enlarging the empire, making it possible for the plan to come to fruition. While the Council of Ten may not have been primarily motivated by liberal idealism, the mandates system offered a practical solution to a practical problem that was politically acceptable.

\subsubsection{The Concept of "Mandate"}

Where did the ideas behind the mandates come from and how was the system of mandates constructed? Article 22 of the League of Nations Covenant defined the rights and duties of mandatories as well as the guarantees and safeguards granted to the inhabitants of the mandated areas. In the following I shall examine Article 22 and the separate mandate agreements that formed the legal framework of the mandates system. These contained various prohibitions and guidelines that varied from one type of mandate to another. What is especially interesting is how the texts sought to safeguard different freedoms, such as freedom of religion, as well as in certain cases in the A mandates even used the language of rights.

The text of Article 22 was deeply imbued with humanitarian ideals as well as paternalistic attitudes towards the less developed. The humanitarian ideals behind the League of Nations mandates system had a long history in Western thought. Early commentators referred to the precedents of the concept of trusteeship and moral obligations towards the colonies in different instances like Spanish

83 The Covenant of the League of Nations (1919), Article 22. 
scholastic thought or British humanitarianism in the nineteenth century. ${ }^{84}$ While by the late $19^{\text {th }}$ century, "humanitarian ideas were already in vogue", 85 part of the sense of urgency came from the so-called scramble for Africa and the ill effects of colonial expansion. In addition to governments, there were groups of private European actors in Africa who expected to benefit from the lack of rules and supervision. As a result, common international rules were needed for Africa, and these were on the agenda of the series of conferences between 1885 and 1912 that established the international accord between the colonial powers. ${ }^{86}$ The League itself described the mandates system as being based on ideas that had been developing for some time "in the minds of idealists, statesmen and experts in colonial matters and international law". ${ }^{87}$ These ideas had led to the abovementioned international conventions, which thus indicated some of the principles of the mandates system in embryo. ${ }^{88}$ The mandates system was in another way similar to the international settlement for the scramble for Africa in that it resolved the issue of equal division of colonies among the victorious Allied powers. ${ }^{89}$

Article 22 of the Covenant of the League of Nations stipulates the basic principles of the mandates system:

To those colonies and territories which, as a consequence of the late war, have ceased to be under the sovereignty of the States which formerly governed them, and which are inhabited by peoples not yet able to stand by themselves under the strenuous conditions of the modern world, there should be applied the principle that the well-being and development of such peoples form a sacred trust of civilisation and that securities for the performance of this trust should be embodied in this Covenant.

The best method of giving practical effect to this principle is that tutelage of such peoples should be entrusted to advanced nations who, by reason of their resources, their experience, or their geographical position, can best undertake this responsibility, and who are willing to accept it, and that this tutelage should be exercised by them as Mandatories on behalf of the League.

The character of the mandate must differ according to the stage of development of the people, the geographical situation of the territory, its economic conditions and other similar circumstances.

${ }^{84}$ Hall, Mandates, Dependencies and Trusteeship, 97; Chowdhuri, International Mandates and Trusteeship Systems, 35-36.

${ }^{85}$ League of Nations, The Mandates System: Origin, Principles, Application, 8.

${ }^{86}$ Hall, Mandates, Dependencies and Trusteeship, 102-103.

${ }^{87}$ League of Nations, The Mandates System: Origin, Principles, Application, 7.

88 Ibid.; Koskenniemi, The Gentle Civilizer of Nations, 170-171.

${ }^{89}$ Knoll, The Legal Status of Territories Subject to Administration by International Organisations, 69. 
Certain communities formerly belonging to the Turkish Empire have reached a stage of development where their existence as independent nations can be provisionally recognized subject to the rendering of administrative advice and assistance by a Mandatory until such time as they are able to stand alone. The wishes of these communities must be a principal consideration in the selection of the Mandatory.

Other peoples, especially those of Central Africa, are at such a stage that the Mandatory must be responsible for the administration of the territory under conditions which will guarantee freedom of conscience and religion, subject only to the maintenance of public order and morals, the prohibition of abuses such as the slave trade, the arms traffic and the liquor traffic, and the prevention of the establishment of fortifications or military and naval bases and of military training of the natives for other than police purposes and the defence of territory, and will also secure equal opportunities for the trade and commerce of other Members of the League.

There are territories, such as South-West Africa and certain of the South Pacific Islands, which, owing to the sparseness of their population, or their small size, or their remoteness from the centres of civilisation, or their geographical contiguity to the territory of the Mandatory, and other circumstances, can be best administered under the laws of the Mandatory as integral portions of its territory, subject to the safeguards above mentioned in the interests of the indigenous population.

In every case of mandate, the Mandatory shall render to the Council an annual report in reference to the territory committed to its charge.

The degree of authority, control, or administration to be exercised by the Mandatory shall, if not previously agreed upon by the Members of the League, be explicitly defined in each case by the Council.

A permanent Commission shall be constituted to receive and examine the annual reports of the Mandatories and to advise the Council on all matters relating to the observance of the mandates.

The paragraph on the A mandates provisionally recognized the communities as independent nations and required "administrative advice and assistance by a Mandatory until such time as they are able to stand alone". The paragraphs on B and C mandates contain more precise "guarantees" or "safeguards" for the inhabitants: freedom of conscience and religion (subject to maintenance of public order and morals), prohibition of the slave trade, arms traffic and liquor traffic and limitations on the use of mandates for military purposes. Robert Cecil noted that the safeguards were those that "the enlightened public opinion demands". ${ }^{90}$ The paragraph also includes equal opportunities for trade and commerce for other

${ }^{90}$ Kluyver, Documents on the League of Nations, 109. 
League members. It has no provision regarding the authority which was to nominate the Mandatories. They were nominated by the Principal Allied and Associated Powers (France, Italy, Japan, UK, USA), based on Article 119, where Germany renounced her rights over her overseas possessions to the Allied powers. ${ }^{91}$

Furthermore, the details of each mandate were written in separate agreements. ${ }^{92}$ However, Article 22 set down the general aim of the system, being the well-being and development of the mandated peoples and the means to achieve it through the tutelage of these peoples by "advanced nations". This tutelage was compared to civil law principles: the mandated peoples were regarded as minors and their "guardians", meaning "the advanced nations", needed to keep a disinterested attitude and were not to exploit "minors" for their own profit. 93 According to the League of Nations, the phrase "peoples not yet able to stand by themselves" meant that the idea was that the mandates were not to be indefinite. ${ }^{94}$

The separate agreements with which the details of all mandates were outlined had originally been intended to become part of the Versailles Treaty. However, by the time the Versailles Treaty was signed, there were still disagreements preventing the concrete drafting of the agreements. ${ }^{95}$ The drafting began by a commission representing the Principal Allied and Associated Powers led by Lord Milner. Japan resented the drafts of the $\mathrm{C}$ mandates on the basis of discrimination. It would have wanted the open door policy to be included in the $\mathrm{C}$ mandates. France's objections relating to the $\mathrm{B}$ mandates were about France's insistence on recruiting natives for military service. ${ }^{96}$ The A mandates were postponed for a lengthier time due to disagreements on the position of Jews in Palestine and especially Americans' insistence on taking care of their interests in the A mandates now that they did not have a mandate of their own.

The C drafts were approved on December 17, 1920.97 The C mandates comprised seven articles. The first article describes the territory to which the mandate applies, the second article the powers ("full power of administration and legislation over the territory subject to the present mandate as an integral portion of [the mandate]") and duties ("shall promote to the utmost the material and moral well-being and the social progress of the inhabitants of the territory subject to the present mandate") of the mandatory. Articles 3-5 described in more detail prohibitions of abuses of the inhabitants of the territory: prohibition of the slave

${ }^{91}$ Chowdhuri, International Mandates and Trusteeship Systems, 71.

92 The terms "charter" or "statute" were used in the Permanent Mandates Commission, Minutes 19 (1930), 175.

${ }^{93}$ League of Nations, The Mandates System: Origin, Principles, Application, 23.

${ }^{94}$ Ibid.

${ }_{95}$ Wright, Mandates under the League of Nations, 45.

96 Ibid., 47.

${ }^{97}$ The separate agreements were published in a supplement in the American Journal of International Law (1923). 
trade and forced labour, control of traffic in arms, control of spirits, limitations to military training, and a clause on religious freedom. Article 6 stipulated the duty to report to the League Council and Article 7 the subsequent modifications and dispute settlement. ${ }^{98}$

The standard agreement for the $\mathrm{B}$ mandates was rather similar to the $\mathrm{C}$ mandates, albeit with more detail. These agreements had a more detailed description of the geographical boundaries of the territories. There was one general article on the duties of the mandatory: the mandatory "...shall be responsible for the peace, order and good government of the territory, and shall undertake to promote to the utmost the material and moral well-being and the social progress of its inhabitants". There were also several more detailed duties concerning slavery, the slave trade, forced labour, arms traffic and liquor sale, taking native customs into consideration in land issues, and freedom of conscience. ${ }^{99}$ The greatest difference to $\mathrm{C}$ mandates was a lengthy article on the open door policy and the fact that international conventions were applicable to the mandated territories. On administration, the agreements declared that " $[\mathrm{t}] \mathrm{he}$ Mandatory shall have full powers of administration and legislation in the area subject to the mandate: this area shall be administered in accordance with the laws of the Mandatory as an integral part of his territory and subject to the preceding provisions". The mandatory could apply its own laws to the territory "subject to modification required by local conditions". The provision also granted the possibility of forming "a customs, fiscal or administrative union or federation with the adjacent possessions under his own sovereignty or control”. Here, however, the British mandate of Tanganyika differed from the others, completely leaving out other mentions of administration and only providing the possibility of a union with bordering territories. ${ }^{100}$ The final articles concerned the duty to report to the League, the requirements for modification and dispute settlement. These were similar to the $\mathrm{C}$ mandates.

The A mandates differed from the $\mathrm{B}$ and $\mathrm{C}$ mandates in the sense that they took more into consideration the local features of the territory, whereas the $\mathrm{B}$ and $\mathrm{C}$ mandates were almost similar (with a few exceptions) to all relevant territories. The A mandates were also much more complex. For example, the mandate agreement for Palestine comprised 28 articles, many of which were specific to the area and its conditions. Nearly half of the articles dealt with issues of religion and the relationships between religious communities. Articles 1 and 2 dealt with administration, declaring that the mandatory has full powers of legislation and administration that must however both secure the establishment of the Jewish national home and "safeguard the religious rights of all the inhabitants of

\footnotetext{
${ }^{98}$ The interpretation of the latter part would later be an integral part of the Case on South West Africa before the International Court of Justice. See chapter 5.

${ }_{99}$ These safeguards will be dealt with in more detail in chapter 3 .

${ }^{100}$ See British Mandate for East Africa, Art. 10.
} 
Palestine, irrespective of race and religion". Article 3 encouraged local autonomy. Article 4 noted the necessity of establishing a Jewish agency as the representative of the Jewish populations and named "The Zionist Organization" as such an agency. ${ }^{101}$ Article 5 prohibited the cessions or lease of any Palestine territory to foreign governments. Article 6 was about the facilitation of Jewish immigration, Article 7 about nationality laws and Palestinian citizenship for Jews, Article 8 about the non-applicability of Ottoman era privileges and immunities of foreigners. Article 9 granted a judicial system with complete guarantee of rights for everyone, as well as respect for personal status and religious interests. Article 10 dealt with the applicability of extradition treaties. Article 11 concerned the administration's duties in safeguarding the interests of the community, control of natural resources, public works, services and utilities and the introduction of a land system, Article 12 the task of the mandatory to control the foreign relations of Palestine. Articles 13 to 16 dealt with religious issues, and the mandatory's duty to safeguard the access to holy places and religious sites and ensure free exercise of worship. The mandatory was also given the task to study and determine "the rights and claims in connection with the Holy Places and the rights and claims relating to the different religious communities in Palestine". The mandatory's task was to ensure complete freedom of conscience and the free exercise of all forms of worship and to ensure that there was no discrimination between inhabitants of Palestine on the grounds of race, religion or language. Article 17 was concerned with the forces for the preservation of peace and order and Article 18 with nondiscrimination against nationals of League member states (open door). Article 19 dealt with adherence to international conventions, Article 20 with disease prevention and combat and Article 21 with the enactment of a law of antiquities. Article 22 settled as the official languages English, Arabic and Hebrew, and Article 23 recognized holy days. Article 25 provided for the possibility of postponing or withholding provisions of the mandate to "the territories lying between the Jordan and the eastern boundary of Palestine" (Transjordan). Articles 24 and 26-28 concerned annual reports, dispute settlement, and the modification and termination of mandates.

For the mandate of Syria and Lebanon, the mandate agreement started with a duty to frame an "organic law" for the territory in agreement with the native authorities and taking into account the "rights, interests, and wishes of all the population inhabiting the said territory". Article 2 dealt with maintaining the mandatory's troops for defence in the territory, perhaps in reference to the continuing presence of French troops in the area since the end of the war. Article 3 was about the mandatory's control of foreign relations and diplomatic and consular protection. Article 4 prohibited lease or secession of the territory. Article 5 concerned the non-applicability of Ottoman capitulations and Article 6 the establishment of a judicial system to ensure natives and foreigners a complete

${ }^{101}$ See more in section 3.2 . 
guarantee of their rights and respect for personal status and religious interests. Article 7 was about extradition treaties and Article 8 on freedom of conscience (in common with Palestine). Article 9 granted immunity of "Councils of management" and religious communities and Article 10 limited the mandatory's supervision of religious communities to maintenance of public order and good government. Article 11 concerned the open door policy (similar to Palestine, but longer and more detailed). Article 12 dealt with international agreements, Article 13 disease combat, and Article 14 antiquity laws. Article 15 dealt with reimbursement of all expenses by local government in organizing administration. Article 16 declared the official languages to be French and Arabic, Articles 17-20 dealt with the duty to make an annual report, modification of the mandate, termination of the mandate and dispute settlement. Syria did not have a constitution until 1929. In May 1930 separate organic laws came into force for the different provinces in Syria.

Due to Iraqi resentment of the mandate regime, the mandate of Iraq was not established with a mandate agreement, but with a treaty between Great Britain and Iraq, concluded between the British Government and King Faisal in October 1922. ${ }^{102}$ A Syrian General Congress meeting which at the same time proclaimed Syria an independent state had named King Faisal the King of Syria in 1920. As Faisal refused to accept France as the mandatory of Syria, he was expelled from Syria and would re-emerge in Iraq, to be crowned the King of Iraq with the support of the British. ${ }^{103}$ The language of the treaty would provide "advice and assistance" from the British, but national sovereignty would remain within Iraq. ${ }^{104}$ In Iraq, the treaty was accepted by a Constituent Assembly.

In addition to the treaty with Great Britain, the Iraqi Constituent Assembly approved the Organic Law of Iraq, containing the Constitution and Electoral Law of Iraq. The Organic Law begins by stating that "Iraq is a sovereign State independent and free". Part I of the Organic Law comprises the "Rights of People", "in accordance with the established traditions of the written Constitutions of Europe and Oriental peoples, the fundamental rights of the people", as Norman Bentwich, then the attorney-general of Palestine described. ${ }^{105}$ Such "rights of man" he continues, "are embodied in generalizations modified by some legal restriction". ${ }^{106}$ Such rights include e.g. personal freedom of all inhabitants, access to the Courts, right to ownership, prohibition of forced labour, freedom of expression and assembly, freedom of belief and freedom to practise forms of worship, and equal rights. These were naturally subject to limitations set

102 See e.g. Sluglett, 'The Mandate System: High Ideals, Illiberal Practices', 38; Fieldhouse, Western Imperialism in the Midde East 1914-1958, 92-97.

${ }_{103}$ Pedersen, The Guardians, 37-41; Pool, 'From Elite to Class: The Transformation of Iraqi Leadership, 1920-1939'.

104 See Treaty between Great Britain and Iraq, Article 1.

${ }^{105}$ Bentwich, The Mandates System, 58.

106 Ibid. 
by laws or caused by threat to public safety, order or morality. ${ }^{107}$ The treaty between Britain and Iraq was to be a temporary one, but its renewal was set aside as the plans for Iraq's independence started to move forward. 108

The individual mandates were accepted by the League of Nations Council as resolutions December 17, $1920 .^{109}$ The question of the legal nature of the separate mandates agreements has remained controversial. ${ }^{110}$ The nature of the instruments was discussed in the case concerning South West Africa, as it had relevance as regards the position and the legal status of the applicants of the case. ${ }^{111}$ The International Court of Justice concluded that the mandates had taken the form of a treaty. The Court, while acknowledging the fact that the mandates were accepted as resolutions, emphasized the novelty of the instrument. The Court called the agreements "special type[s] of instrument[s] composite in nature and instituting a novel regime." According to the Court, the mandates had a different type of character than merely an executive action. This was in the Court's view apparent in the preamble of the mandates. ${ }^{112}$ The Court saw the mandates as consisting firstly of a tentative agreement on the terms of the Principal Allied and Associated Powers to be proposed to the League Council and secondly of a confirmation agreement on the terms defined by Council and agreed between the Council and the mandatory. The Court saw no legal significance in the language of the instruments, i.e., in the term "declaration". ${ }^{113}$

However, in their dissenting opinion, judges Spender and Fitzmaurice were not ready to accept the view of the majority of the judges. The two judges contested the treaty making capacity of the League of Nations at the time. Moreover, they reminded that there had been initial plans to make the mandates in the form of a treaty, but such plans had not been followed. As conclusion, they stated that "the Mandate, in its final form, was the act of an organ of an international organization in active exercise of power conferred on it by its constitution." ${ }^{114}$ Moreover, there was the question of who would have been the

\footnotetext{
${ }^{107}$ See part I, sections 16-18.

108 Bentwich, The Mandates System, 65.

1092 League of Nations Official Journal (1921) 84-96. Includes also the texts of the C mandates.

${ }^{110}$ Simma et al. (eds.), The Charter of the United Nations. A Commentary, 1868; Klabbers, The Concept of Treaty in International Law, 182-187.

${ }^{111}$ See Chapter 5 below.

112 See e.g. the Mandate for German Samoa, preamble: "Whereas His Britannic Majesty, for and on behalf of the Government of the Dominion of New Zealand, has agreed to accept the mandate in respect of the said territory, and has undertaken to exercise it on behalf of the League of Nations in accordance with the following provisions..."

113 South West Africa Cases (Ethiopia v. South Africa; Liberia v. South Africa), Preliminary Objections, Judgment of 21 December, 1962: I.C.J. Reports, 1962, 319, 330332.

114 South West Africa Cases, Preliminary Objections (1962), 319, joint dissenting opinion of Sir Percy Spender and Sir Gerald Fitzmaurice, 485.
} 
parties to the mandate treaties, if the agreements were seen as such? ${ }^{115}$ Judge Bustamante had already in the 1950 advisory opinion on South West Africa maintained that the parties were the inhabitants of the mandated territories and the mandatory. Yet, the inhabitants had no role in establishing the mandates, thus it would have been far-fetched to see them as active parties to a treaty. Even less than the League of Nations, they did not have such a legal personality as would have been needed for them to become party to an international treaty. Spender and Fitzmaurice studied the possibility of the Allied Powers and the individual members of the League as possible treaty parties, but concluded that most likely the treaty would have been concluded between the League of Nations and the mandatories. Here they returned to the problem of the lack of legal personality of the League. ${ }^{116}$ As the League did not in their view possess sufficient powers to conclude treaties, the acts could only be seen as quasi-legislative acts of the League Council. ${ }^{117}$ As their starting point the judges noted that it was not necessary for the instrument to be a treaty in order for it to give rise to international obligations. ${ }^{118}$ Throughout the existence of the mandates, the existence of such obligations was never contested by any of the parties. As a legal issue the question arose only as part of the pleadings on South West Africa in the ICJ. Thus, even if the questions of the legal status of the individual mandates remains unsolved, this had little effect in the actual working of the mandates.

That the mandates came to be called "mandates" was in and by itself a result of a considerable search for a suitable word to describe the system of guardianship that was established. ${ }^{119}$ The Roman law institution of mandatum gave its name to the system but its contents were established by Article 22 of the Covenant of the League of Nations, as well as separate agreements between the League of Nations and the mandatories. The League itself saw the mandates as the embodiment of humanitarian ideals, but the agreements were contracts drafted by lawyers which instituted a series of obligations and safeguards to protect the mandates and their inhabitants. Like in the civil law system of guardianship, the aim of the mandates was to be of benefit to the mandated areas. While the system was constructed as a guardianship of the advanced nations over those unable to stand by themselves, the language of rights through which Article 22 and the agreements were written, was intended to underline the differences between the mandates system and the old colonial regimes and to ensure that the mandates remained separate from the colonies.

\footnotetext{
115 Ibid. 495.

116 Ibid. 502.

117 Ibid. 486.

${ }^{118}$ Ibid. 477.

119 On the origins of the term 'mandate', see e.g. Potter, 'The Origin of the System of Mandates: Further Notes'.
} 


\subsubsection{The Problem of Sovereignty}

The issue of sovereignty was one of the most central problems of international law with regard to the mandates. But what was the position of the mandates? Were they under the sovereignty of the League of Nations, the mandatory, or where they something in between? In the following we shall explore the evolution of use from contemporaries like Lauterpacht to the post-war observers. While Lauterpacht begins with the origins of the mandates in the Roman law tradition, for him the central characteristic was its transitional nature. Others debated whether the mandatory relationship was that of guardianship, tutelage or trust: Who had the final say in naming the mandatory and who determined when the mandates would begin and end?

There were several interpretations by different lawyers on who had sovereignty over the mandates. The principal alternatives presented were that sovereignty over the areas was vested on 1. the League of Nations, 2. the victorious Allied powers, 3 . that there existed a shared sovereignty between the mandatories and the League, 4. that sovereignty had reverted to the inhabitants of the area due to the abolition of colonies, or 5. that the issue of sovereignty was unresolved and remained so due to the co-operation of the League and the mandatories. ${ }^{120}$

Hersch Lauterpacht had a long interest in the mandates starting from the very early years of the system. ${ }^{121}$ He wrote a thesis on the topic in 1922, which was submitted to the University of Vienna. He continued researching the mandates in his later works and referred to them in his post World War II writings on human rights. Lauterpacht's stance on colonialism was twofold. On the one hand, he was an admirer of the British colonial tradition, which applauded itself for the abolition of the slave trade, for treaties protecting natives and for taking into consideration the welfare of natives. ${ }^{122}$ For Lauterpacht a liberal tradition had developed in the $19^{\text {th }}$ century and humanitarian sentiments towards natives were an essential part of it. ${ }^{123}$ On the other hand, the First World War formed an exception to this tradition that he was still eager to find. ${ }^{124} \mathrm{He}$ also disagreed with the "ruthless economic exploitation of native peoples", prominent in European

\footnotetext{
120 van Rees, Les Mandats Internationaux, 18-24 presents a typical account of the different opinions and the scholars who held them. Quincy Wright has counted ten different theories of sovereignty by different authors, many of them, however, combinations of the principal theories. Wright, Mandates under the League of Nations, 319.

121 Lauterpacht's interest in the mandates and especially his reluctance towards the annexationist politics of some of the mandatories were closely related to his Zionist interests. Koskenniemi, 'Lauterpacht: The Victorian Tradition in International Law', 229_ 230 .

122 Ibid., 220; On the British colonial tradition, see e.g. Lugard, The Dual Mandate in British Tropical Africa.

${ }^{123}$ Koskenniemi, 'Lauterpacht: The Victorian Tradition in International Law', 220.

124 Ibid., 217.
} 
colonialism in general. ${ }^{125}$ For him, the mandates provided a welcome exception, a new way to handle the problems relating to colonialism.

Lauterpacht noted that the mandates were a concept of Roman law that was accepted by all systems of private law, and were now raised to a position of an institution in international law. ${ }^{126}$ Thus, Article 22 formulated the mandate as a positive creation of international law. ${ }^{127}$ According to Lauterpacht, the position of mandates in international law was that the mandatory was the administrator and exercised all sovereign rights. However, the mandates were not a part of the territory of the mandatory and the inhabitants had their own nationalities. ${ }^{128}$ Also the word "tutelage" as the purpose of the mandate meant that the League of Nations had certain sovereign power in the mandated areas. He noticed a gap between Article 119 in the Versailles Treaty ${ }^{129}$ and Article 22 of the League Covenant. However, he found that Article 22 Part 2 revealed that the sovereignty was within the League of Nations, and had it not been clear, at the latest the limitations in Parts 4-6, including for instance the abolishment of slave trade, revealed the location of sovereignty. ${ }^{130}$ There were certain shortcomings in the sovereignty of the League of Nations. For instance, France and Britain denied that the League of Nations could appoint the mandatory, whereas Germany believed it to be the only possibility. ${ }^{131}$ However, Lauterpacht found that the sovereignty to be vested in the League of Nations did not require that the mandatory be assigned by the League. To prove that the mandatories did not possess sovereignty in the mandates, it was sufficient that limitations existed for the mandatories. The right of the mandatories to act in regard to the mandates was limited in three ways: the sovereignty of the League of Nations, as provided by Article 22, the nature of the mandates, and the individual provisions of the same article. Lauterpacht did accept that the League of Nations not choosing the mandatory were "certainly more than aesthetic shortcomings in the Mandates system". Yet, he did not see this as decisive. ${ }^{132}$ Firstly, the mandates had a transitory character, especially the A mandates. Secondly, the obligations of the mandatory were a sign of a new policy of colonization. Thirdly, every League member could actively intervene if the mandatory power did not comply with its

${ }^{125}$ Lauterpacht, 'The Mandate under International Law in the Covenant of the League of Nations', 39.

126 In Roman law mandatum or mandate was a private law contract in which one person promised to do something at the request of another without compensation.

${ }^{127}$ Lauterpacht, 'The Mandate Under International Law in the Covenant of the League of Nations', 60.

128 Ibid., 49.

129 "Germany renounces in favour of the Principal Allied and Associated Powers all her rights and titles over her oversea possessions."

${ }^{130}$ Lauterpacht, 'The Mandate under International Law in the Covenant of the League of Nations', 69.

131 Ibid., 70.

132 Ibid., 82. 
obligations; and fourthly, the mandatories had an obligation to submit reports and the League of Nations had a right to control the mandates or the actions of the mandatories. ${ }^{133}$ Finally, there was a clause concerning the Permanent Court of International Justice, which Lauterpacht interpreted as meaning that every member of the League of Nations could take an issue to the Court concerning non-compliance with any conditions of the mandate. ${ }^{134}$ The mandatories were not the mandator, the entity in whose name the mandates were governed. ${ }^{135}$ Lauterpacht also emphasized that on a general and a principal level, the $\mathrm{C}$ mandates did not differ from the A and B mandates. The purpose of the mandates was to act as an opposite to annexation, even in the weakened form of the $\mathrm{C}$ mandates. ${ }^{136}$

Another influential early observer, Walther Schücking, a German Professor of International Law and later Judge at the Permanent Court of International Justice, saw that the mandates were administrated in the name of the League of Nations so that the League of Nations had the sovereignty and the mandatories were its organs. This was in balance with the well-being and development of the natives, as stated in the first part of Article 22. For him Article 22 was the first time when the well-being of peoples was settled on a more general level. Earlier instruments, for instance those limiting the slave trade, had been specialized. The issues of the mandates could not be domestic but they did have to do with the rights and duties of the League of Nations, as the League guaranteed the wellbeing and the development of peoples. Schücking's insistence on the sovereignty of the League of Nations may be a consequence of his liberal pacifist and socialist tendencies, ${ }^{137}$ but it also fitted the German view of keeping its former colonies under the League of Nations and out of the hands of the Allied powers. ${ }^{138}$ Schücking had been a member of the German delegation at the Paris Peace Conference. ${ }^{139}$ Schücking's and Hans Wehberg's commentary on the League Covenant, Die Satzung des Völkerbundes, was widely read and Schücking would also become well received outside of Germany.140 What he called the "Kulturgemeinschaft" (cultural community) could only be taken care of if the colonies were administered by the League. As the sovereign, the League of Nations could get rid of one mandatory and exchange it for another. This was also reinforced also by the fact that only members of the League of Nations could be mandatories. If other countries could be mandatories, it would be a lot more

\footnotetext{
133 Ibid., 82-83.

134 Ibid., 81.

135 Ibid., 78.

136 Ibid., 50.

137 Koskenniemi, The Gentle Civilizer of Nations, 215; Tams, 'Re-Introducing Walther Schücking', 727, 731.

138 Pedersen, The Guardiand, 205, 221.

139 Koskenniemi, The Gentle Civilizer of Nations, 215.

140 Ibid., 216; Tams, 'Re-Introducing Walther Schücking', 732-734.
} 
difficult for the League of Nations to use its sovereign powers on them. Another reason why it was essential that the mandatories could be gotten rid of if necessary was that one day they would be gone when the mandates would become independent. ${ }^{141}$ Like Lauterpacht, he also noted the discrepancy between Articles 119 of the Versailles Treaty and Article 22 of the League of Nations Covenant, but concluded that Article 22 evidenced with absolute certainty that the transfer of the German colonies should only be temporary, and thus the meaning was that the mandates would be under the sovereignty of the victorious states only up to the time when the League of Nations would start taking care of them and name the mandatories. ${ }^{142}$

French commentators showed a more reserved approach towards the mandates system, tending to see it as a continuation of the colonial system and the commercial interests of the mandatories. The Polish Professor of Law Julien Makowski found two legal relationships, one between the mandatory and the inhabitants of the territory and the other between the League of Nations and the mandatory. ${ }^{143}$ Also he saw the position of the mandatory as a guardian and the mandates as a guardianship. ${ }^{144}$ The first relationship, between the mandatory and the individuals, was of protection and guardianship. The second relationship was about the legal status of the mandates and their sovereignty. The winners of the First World War had obtained the German and Turkish territories and the mandates were self-set limitations to their sovereignty. ${ }^{145}$ According to Makowski, the League of Nations had a duty to protect indigenous populations, but it did not possess a legal title to care for the relationship between the mandatory and the mandated territory. ${ }^{146}$ The mandatory powers held the mandated territories by right of conquest or by virtue of assignments, not by delegation of the League of Nations. ${ }^{147}$ Also, should the League of Nations be dissolved, the territory would remain under the sovereignty of the mandatory. ${ }^{148}$

For French authors it was difficult to believe that the British held mandates solely for humanitarian purposes. André Blondel was particularly suspicious of the independence of Iraq, reminding others that the British still had wide rights regarding the territory. He noted that the independence of Iraq was a precedent to the other territories as well and might hasten the release of the other territories, such as mandated Syria. Of course, a precedent also set certain rules for the procedure, conditions and guarantees, but at the same time he seemed to believe that for Britain this was but one step in its old colonial policies, "another branch of

\footnotetext{
${ }^{141}$ Schücking and Wehberg, Die Satzung Des Völkerbundes, 700.

142 Ibid., 701.

${ }^{143}$ Makowski, 'La Nature Juridique Des Mandats B et C', 374.

144 Ibid., 383.

145 Ibid., 385.

146 Ibid., 386.

147 Ibid., 389.

148 Ibid., 390.
} 
the Imperial Road". ${ }^{149}$ Also, there was a risk of emerging nationalism, which independence could bring to the fore.

The Comte de Moncharville, Professor of Law at the University of Strasbourg, reminded people of the diligence of France's reporting to the League of Nations. He talked about work done against slavery, labour conditions, vaccinations, freedom of religion, getting rid of polygamy, and promoting education. He noted that there were several possibilities for arranging the sovereignty of the territories, but did not specify which was the one he believed to be the most credible one. ${ }^{150}$

Albert Millot also saw the British as extending their policies to the mandates rather than taking care of their mission. He claimed that the use of Syrian mandates for the French was extending the "the glory of France". It was expensive for the state but good for commerce. There was much talk and many fancy ideas but in essence he saw the mandates as an extension of colonialism. The mandates were at the same time political, legal and economic, the last being the reason why the French wanted them. Mandates continued the practice of colonial governance allowing colonizers to continue with their traditions. ${ }^{151}$

Quincy Wright, the American political scientist and international lawyer, refused to take a stance on the location of sovereignty: "It is not certain that complete sovereignty rests anywhere", he maintained soon after the establishment of the mandates. In Mandates under the League of Nations (1930) he introduced the reader to the different theories of sovereignty in the mandated territories. Sovereignty could be vested in the Principle Allied and Associated Powers, in the mandatories themselves, the mandated communities or the League of Nations. Each of these forms of sovereignty could be supported by various authors and actors within the mandates system. Wright also pointed to the various political and sentimental reasons why the different actors thought as they do. Lawyers, however, had neglected to state precisely their theory on "the concept of sovereignty" and "the sources of law applicable". ${ }^{152}$ Therefore, he concludes that there is not enough consensus amongst jurists to determine the source of sovereignty or the method to interpret it. Thus, "most of the jurists agree that the essential characteristic of the system is the assurance, through gratuitous activity of a mandatory acting under supervision of the League, of certain defined rights in the territories." 153 According to Wright, the source of sovereignty was not as such a relevant issue in the mandates. What mattered was that the territories gained certain advantages through a joint effort by the mandatory and the League.

\footnotetext{
149 Blondel, 'Le Cessation Des Mandats et Le Cas de l'Iraq', 644-645. Translation.

${ }^{150}$ Moncharville, 'L'execution Du Mandat Français Au Togo et Au Cameroun', 62.

151 Millot, Les Mandats Internationaux; étude Sur L'application de L'article 22 Du Pacte de La Société Des Nations.

${ }_{152}$ Wright, Mandates under the League of Nations, 340.

153 Ibid, 344.
} 
Similarly, Norman Bentwich, the Attorney-General of Palestine, looked at the question of sovereignty more from the point of view of the outcome of the mandates system. Bentwich compared the theories of sovereignty with the "dominant thesis" of non-annexation. This meant, according to him, that sovereignty could not be possessed by the mandatories. He saw the entire concept of sovereignty modified by "the recognition of a new creation of political science and a new relationship in International Law". ${ }^{154}$ The mandated territories were governed on behalf of the League with two purposes, depending on the territory. According to him, the first purpose was to prepare the peoples for selfgovernment, the other a trust for the well-being of the inhabitants. ${ }^{155}$

The British barrister James C. Hales did not believe that any individual body could have sovereignty over the territories. He also agreed that the mandatories only had the right to exercise the powers of sovereignty, but sovereignty was not vested in them. He also noted the treaty restrictions on the rights to exercise this sovereignty and the condition that when the territory was able to stand by itself, the exercise of sovereignty by the mandatories would end. The League of Nations acted as a trustee for the territories which restricted the exercise of sovereignty as well. However, the League was not the holder of sovereignty as such, as no one was, but only acted as a trustee. ${ }^{156}$

In a later article written in the final years of the mandates, Hales clarified his position on sovereignty and instead of vesting it in no one, he wrote of a combined sovereignty of the League of Nations and the mandatories. The administrators, according to him, were merely trustees, whose duty was to carry out the task until it was ended. Thus, he emphasized the temporary nature of the mandates, reminding people however that in the case of the $\mathrm{C}$ mandates it was not as likely that the mandates would end at some point when compared to the other mandates. ${ }^{157}$ The legal title to the mandatory powers came from two different sources. It was conferred both by the Principle Allied and Associated Powers and by the League of Nations. ${ }^{158}$ The obligations to the mandatory powers were binding, as they were granted in treaties that had been entered into between the mandatories and the League. With these treaties the League (the trustee) delegated its trust to the mandatories acting as its agents. As treaties are normally binding in international law, the treaties concerning the mandates did not make an exception. He also believed that this new standard of administration was superior to the one that had existed before. Many abuses had existed during old colonial regime and the limitations set in paragraph 5 of Article 22 existed in order to limit

\footnotetext{
${ }_{154}$ Bentwich, The Mandates System, 20.

155 Ibid.

156 Hales, 'Some Legal Aspects of the Mandate System: Sovereignty - Nationality Termination and Transfer'.

157 Hales, 'The Creation and Application of the Mandate System. (A Study in International Colonial Supervision)', 191-193.

158 Ibid., 194.
} 
the possibility of abuses. Thus, the League of Nations had a direct interest in the welfare of the inhabitants.

Interpretations on the issue of sovereignty would change radically after the Second World War. While the interwar debates on the issue of sovereignty were by and large about whether sovereignty would rest on the mandatory, as was the case in colonial arrangements or with the League, after the war, the principle of self-determination and its realization became a central preoccupation.

Of the post war interpretations, Duncan Hall, the Australian historian and author of Mandates, Dependencies and Trusteeship, did not make much of independence as a goal for the trust. He believed that as an objective, independence could lead anywhere and would not necessarily be an improvement for the people. The word "trust" as such said as little as trusteeship or tutelage. On the other hand, what trust ought to be about was "education for self-government", as this would lead to the "self-government of a free people standing on its own feet as a result of a process of education. This was the full liberal intent of the Covenant". ${ }^{159}$ However, at least in some of the territories, progress was bound to be slow, ${ }^{160}$ but nevertheless, education for self-government would provide a "ladder ... which primitive native tribes could climb steadily to the goal of a selfgoverning people". ${ }^{161}$

Even in 1955 Ramendra Chowdhuri was not ready to give an opinion on the question of sovereignty. In International Mandates and Trusteeship Systems: A Comparative Study, in a section aptly named "Estimate", he notes that there is an "element of uncertainty and ambiguity" in the legal status of mandates (as there was also in United Nations trusteeships).162 Perhaps there was no solution. As some have pointed out, the system was new and therefore the old concept of sovereignty simply did not apply any longer, or even have much relevance. The ultimate goal of such territory was self-government or independence, and once that was achieved, the answer to the question of the placement of sovereignty would become clearer. ${ }^{163}$

Many regarded granting independence to African or Asian peoples as irresponsible, a path to chaos. Self-determination as a principle was for Europeans. ${ }^{164}$ These opinions, coming just some years before the African independence movement, show how slowly change was accepted.

The extraordinary position of the mandates in the international legal system was nowhere more apparent than in the discussions over the issue of sovereignty over the mandates. Many of the debates over the question who had sovereignty

\footnotetext{
${ }^{159}$ Hall, Mandates, Dependencies and Trusteeship, 94.

160 Ibid., 95.

161 Ibid., 97.

162 Chowdhuri, International Mandates and Trusteeship Systems, 235.

163 Ibid., 236.

${ }^{164}$ Mazower, No Enchanted Palace, 193.
} 
over the mandates reveal the legal indeterminacy and uncertainty as well as the political quarrels surrounding the notion of "mandate". ${ }^{165}$ Internationalist and idealist authors, like Lauterpacht and Schücking, thought that while the mandatories exhibited many of the traits that were traditionally associated with sovereignty, ultimately sovereignty rested on the League of Nations. Germany after joining the League was one of the most vocal defenders of the League's sovereignty over its mandates. Others were more prone to grant sovereignty to the mandatories, ascribing the League only a supervisory role. Many international lawyers in fact refused to ascribe sovereignty to any individual body, considering the mandates to be outside of old concepts like sovereignty. The issue was revisited after the Second World War and the abolition of the League of Nations as the rise of independence movements brought the ultimate aim of independence into the discussion.

\subsubsection{Was the Mandates System Merely a Continuation of Colonization?}

The mandates system was established at a time when the colonial empires, the foremost of them being Britain, controlled vast tracts of the globe. From the beginning of the $20^{\text {th }}$ century, colonial powers were increasingly concerned about the ethical justification of colonial rule. Though the formulators of the mandates system were adamant that they were constructing a novel system of international governance based on ethical principles and self-governance, the question remains. Was there a difference between old colonial administration and the mandate system? Similar humanitarian justifications such as the abolition of slavery were presented in favour of both.

The use of international law and international organizations for the advancement of liberal and humanitarian ideals had spread during the late $19^{\text {th }}$ and early $20^{\text {th }}$ century. In the late $19^{\text {th }}$ century, international law associations were established by liberal lawyers to spread liberal ideas. In 1868, Gustave RolinJacquemyns, Tobias Asser and John Westlake established the Revue de droit international et de législation comparée. ${ }^{166}$ The establishment of the institute and the Revue were a turning point in rational and moral international law. The earlier idea of the "noble savage" and universal law which had dominated the discourse of international law since the $18^{\text {th }}$ century had changed to the idea of European superiority, European international law and the duty to civilize those on a lower level of civilization. Whereas international law had earlier had certain universal features, now it was thought that societies outside Europe were not only different but also inferior. Inhabitants of "uncivilized" societies were treated as barbarians, not very different from children, to whom an organized society like that of Europe

165 Craven, The Decolonization of International Law: State Succession and the Law of Treaties, $151-52$.

166 Koskenniemi, The Gentle Civilizer of Nations, 14. 
was impossible. 167 Towards the end of the $19^{\text {th }}$ century, the idea of the humane treatment of natives and universal law that had been based on some kind of a natural law, had become outdated and was replaced by a belief in the development of societies from primitive to civilized. International law as such had not been applied to "primitive" people even earlier, but natural law had provided for a certain degree of legal protection. The idea of development also acted as a justification for colonial administration: civilization became the measuring stick with which societies outside Europe were assessed, and colonialism could be justified by spreading civilization outside Europe. Even though there were differences amongst international lawyers in how they saw the civilizing mission of Europe, ${ }^{168}$ generally speaking the lawyers agreed with European colonial policies. Even those with the most humanitarian attitudes towards the inhabitants of the colonies (e.g. the Swiss Joseph Hornung) could be described as paternalists. Hornung, for instance, believed that colonies were justified in the interests of their inhabitants. The inhabitants were to be treated as children, gently but with a firm hand. ${ }^{169}$

This discussion did not apply only to the colonies, but also to Europe's relationship with other nations, such as the Ottoman Empire, Japan and China. Europe searched for standards that would determine when a state would sufficiently resemble Europe for it to be included in the international community and international law. Setting civilization as a standard meant that a sufficient similarity with Europe was required. Europe set the standard, and no external measures existed. For this reason, it was always possible to leave Turkey and Japan in a position where they constantly needed to prove their standard of civilization. ${ }^{170}$ This was also apparent in the reactions of the Western drafters of the Covenant of the League of Nations to Japan's request for a clause on racial equality. ${ }^{171}$ The standards of civilization and the measures of development could be seen equally within the mandates system in the division between the $\mathrm{A}, \mathrm{B}$ and $\mathrm{C}$ mandates according to the perceived level of development and civilization.

On paper and in speeches, the mandates were drafted to take care of the interests of the inhabitants of the mandated areas. As Woodrow Wilson explained,

${ }^{167}$ Ibid., 76.

168 Ibid., 100-115; Hornung, 'Civilisés et Barbares'; Liszt, Das Völkerrecht. Systematisch Dargestellt.

${ }^{169}$ Koskenniemi, The Gentle Civilizer of Nations, 129-130.

170 Ibid., 135; Gong, The Standard of 'Civilization' in International Society. Wheaton, Elements of International Law, 46, famously defined international law as deriving from the "civilized, Christian nations", while Bluntschli mentioned civilized nations in the title of his book. Bluntschli, Das Moderne Völkerrecht Der Civilisierten Staaten Als Rechtsbuch Dargestellt; Bonfils, Manuel de Droit International Public, 19; Despagnet, Cours de Droit International Public, 58; Westlake, International Law, Part 1, Peace, 1-10 all defined the standard of civilization as European.

${ }^{171} \mathrm{Su}$, 'Woodrow Wilson and the Origins of the International Law of Religious Freedom'. See section 3.2 below. 
"the Mandatory system was not intended to satisfy merely the interests of the Mandatory power but to care for, protect and develop the people for whom it was intended". ${ }^{172}$ Of course, this could mean a great many things, and even a willing and benevolent administration would resort to paternalism rather than emphasize safeguarding the natives' rights. A less benevolent colonial administration could call any abuse "assisting" or "protecting" the natives. The apartheid homelands for native peoples in South West Africa serve as an example of the latter.

On the whole, the inhabitants were ignored in the drafting process of the mandates. ${ }^{173}$ During the drafting, the only recorded protest from an inhabitant of the mandated territories came from Kazem-El-Hussaini, Chairman of the Executive Committee of the Arab Palestine Congress, "against the principle of the Jewish National Home in Palestine". ${ }^{174}$ On the other hand, several philanthropic organizations participated in the drafting process, including the Native Races and the Liquor Traffic United Committee and the Anti-Slavery and Aborigines Protection Society (London), which demanded the "prohibition of liquor traffic", "conscription of natives in the army", and "abolition of slavery particularly in the African Mandates”. ${ }^{175}$

As there were no direct precedents, it was difficult to see what kind of shape the mandate system would take at the moment of its establishment. The main issue was naturally whether there was any real difference between the mandates and traditional colonial administration. British Prime Minister David Lloyd George noted at the Paris Peace Conference that he saw no great difference "between the mandatory principle and the principles laid down by the Berlin Conference", apart from the external machinery of the former, ${ }^{176}$ or, in other words, the lack of supervision of the latter. ${ }^{177}$

Article 22 of the League Covenant defined the newly-established system as a "sacred trust", begging the question what was meant by trust. Article 22 provides only a vague idea, according to which the well-being and development of such peoples (i.e. peoples not yet able to stand by themselves under the strenuous conditions of the modern world) form a sacred trust of civilization and that securities for the performance of this trust should be embodied in the Covenant of the League of Nations. The source of the expression "sacred trust" is not clear but reflected both humanitarian paternalism and a Christian influence. Commentators on the mandates gave different interpretations for the term. These interpretations naturally reflected their views on the mandatory system as compared to earlier colonial governance and would radically change through the years.

172 Wilson, at the Council of Ten, Paris, January 30, 1919, cited in Miller, Drafting the Covenant, Vol. 2, 197.

173 Chowdhuri, International Mandates and Trusteeship Systems, 83.

1742 League of Nations Official Journal (June 1921), 331-340, 441-442.

1752 League of Nations Official Journal (October 1921), 823-829.

${ }_{176}$ Hall, Mandates, Dependencies and Trusteeship, 103.

177 Ibid., 105. 
Hersch Lauterpacht saw Article 22 as a compromise between humanitarian requirements towards natives, and the traditional imperialist principle of power. ${ }^{178}$ Paragraph 1 of the Article was an expression of the "high humanitarian task of the civilized nations towards peoples in a culturally lower position". ${ }^{179}$ The interests and rights of the administrating nations were less important than their duties towards the inhabitants of these territories. This was different compared to earlier colonial administration where administrators were restricted in a binding and farreaching manner. ${ }^{180}$

The reasons for this change were both political and related to the spirit of the time. Lauterpacht was hopeful, as this spirit brought about an entire instrument and a new international legal institution. He differentiated between the old and the new, between the territories under the sovereignty of the countries that were defeated in the war and the new position of these territories as mandates. ${ }^{181}$ According to Lauterpacht, it was high time to stop concentrating on the faults of the mandates and talking about them as a continuation of the old power, and accept the mandates as an international institution. ${ }^{182}$ The task of the mandates was to protect the inhabitants from the exploitation of the old system, and support the development of the peoples. One such task close to Lauterpacht's heart was establishing a Jewish national home in Palestine. ${ }^{183}$

With his thesis Lauterpacht not only wanted to contribute to the understanding of mandates as a novel legal concept, and not only as something hiding the imperialist annexationist aims of the victors, but also as a contribution to legal theory. In Lauterpacht's view, the mandates were not to exist indefinitely, although this was only indirectly expressed by the sentence "until they are able to stand by themselves". ${ }^{184} \mathrm{He}$ tried to define the meaning of the concepts behind the mandates, "trust", "tutelage", and "mandate". Of these concepts he considered that the term "mandate" had a legal meaning. The two others, "tutelage" and "trust" did not. ${ }^{185} \mathrm{He}$ noted that many believed that the concept of "trust" was behind the mandates. He realized that it was an important concept in English law, but for him it could not be the main idea as "it seems to me very questionable to take this institution, which constitutes a sort of combination of mandate and deposit of property for the purpose of guardianship, as a basis for the mandate in

${ }^{178}$ Lauterpacht, 'The Mandate under International Law in the Covenant of the League of Nations', 40.

179 Ibid., 42.

180 Ibid.

181 Ibid., 67.

182 Ibid., 84.

183 Ibid.

${ }^{184}$ Lauterpacht, 'The Mandate under International Law in the Covenant of the League of Nations', 42.

185 Ibid., 43. 
international law." 186 For him, it did not give a proper explanation of the idea behind the mandates, though he noted, "it should not be denied that certain peculiarities of the 'trust' ... could be of relevance for an understanding of the Mandates system". 187 Thus, he wanted to emphasize that the term "trust" was not the most important one in understanding the mandates, but it did have some relevance. On the other hand, the word "tutelage" was only to indicate the purpose of the system and had no legal meaning as such. Even the term "mandate" had different possible meanings. The Anglo-German meaning was that the mandator was always above the mandatory, assigning the mandatories and deciding on the terms of the mandate, whereas on what he called the Western side and partly in the practice of the League of Nations, the idea was different. In that tradition, even sovereignty could be moved to the mandatory. ${ }^{188}$

Norman Bentwich noted that "trust" had been used as a moral declaration in relation to African colonies by Joseph Chamberlain, who spoke of them as "undeveloped estates of Europe which were held by England as trustees for civilisation". ${ }^{189}$

Lord Lugard, writing in the 1920s, interpreted the concept of trust in the colonial context. For Lugard, the mandates were the "latest expression of the conscience of Europe". ${ }^{190}$ He believed that the principles applied would not only concern mandates but also the other territories under the administration of the mandatory powers. ${ }^{191}$ The mandates served as "a model and an aspiration". ${ }^{192}$ Tutelage meant acceptance of control primarily in the interest of the inhabitants. ${ }^{193}$ Due to the "advantages of an inherited civilisation", "superior intellectual culture" and "physical superiority", the governing nations had both moral and material obligations towards the natives. ${ }^{194}$ Lugard was keen to emphasize the Britishness of the system. According to him, British ideals came to life in the mandates, including indirect administration, where local officials were given administrative duties under the guidance of the British. ${ }^{195}$

The Swiss William Rappard, Lugard's fellow member of the PMC, was an internationalist and an ardent believer in international collaboration. ${ }^{196}$ In his view the League was the natural result of an "instinct of preservation" of states. "I believe its [the League of Nations'] essential aim, the substitution of law and order

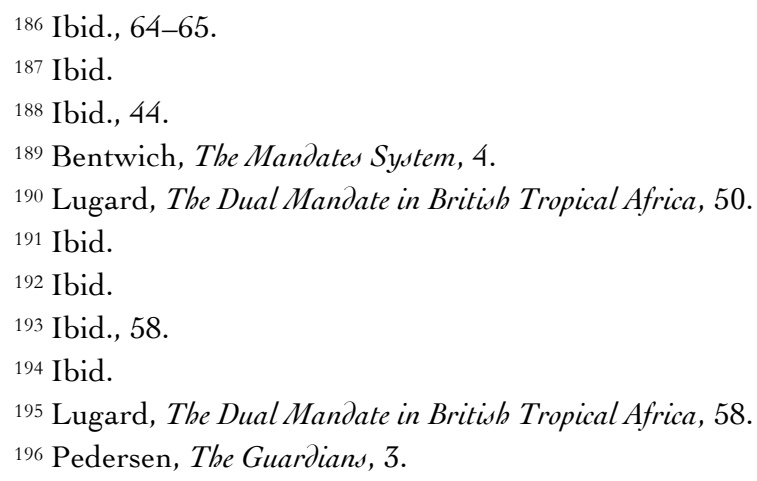


for chaos in international relations, to be so absolutely beneficent and so clearly in the line of human evolution, that no one but a madman or a criminal can repudiate it", he declared.197 For him, imperial order would be transformed by the mandates system by subjecting imperial rule to international control. ${ }^{198}$ His optimism was mainly based on his respect for the PMC. ${ }^{199}$ He hoped that the mandates system would prove to be a "superior method of colonial government", benefiting both the inhabitants of the territories and the "civilized" world at large. ${ }^{200}$ His enthusiasm was tangible when he told how he hoped the mandates system would prove to be "the beginning of a very significant and fortunate revolution in colonial administration",201 and "a great novel enterprise of international coöperation for the amelioration of colonial conditions". ${ }^{202}$

Mark Carter Mills, at the time Assistant in Economics and Sociology at the Indiana University, also saw the mandates as an opportunity to solve the colonial issue in a way that took native interests into consideration. ${ }^{203} \mathrm{He}$ also reminded people that Woodrow Wilson had made a "fundamental contribution" when demanding that native rights be taken into consideration in his Fourteen Points. ${ }^{204}$

The British lawyer Duncan Campbell Lee saw British colonial policies as an inspiration for the mandates and the ideas behind them. ${ }^{205} \mathrm{He}$ was sorry that there was a misunderstanding amongst some British who believed that the territories had become part of Britain and thought that if they had been more understood through the notion of "trust", which also existed in British law, it would have been easier to understand the true nature of the mandates. ${ }^{206}$ "There is no disguise about Mandates. The scheme was not intended to deceive anyone [...]. We have done, I hope for ever, with the barbarous idea of expropriating one set of humanity by another. The Mandatory System is confessedly an alternative to the division of peoples as spoils of war." 207 He noted that the well-being and the development of peoples had been the motive behind British colonial actions for five generations. ${ }^{208}$ He gave examples from the mandates and gave credit to the administrators for developing the territories and noting that conditions in these territories had been bad before setting up the mandates. For example, in the Cameroons, repulsive

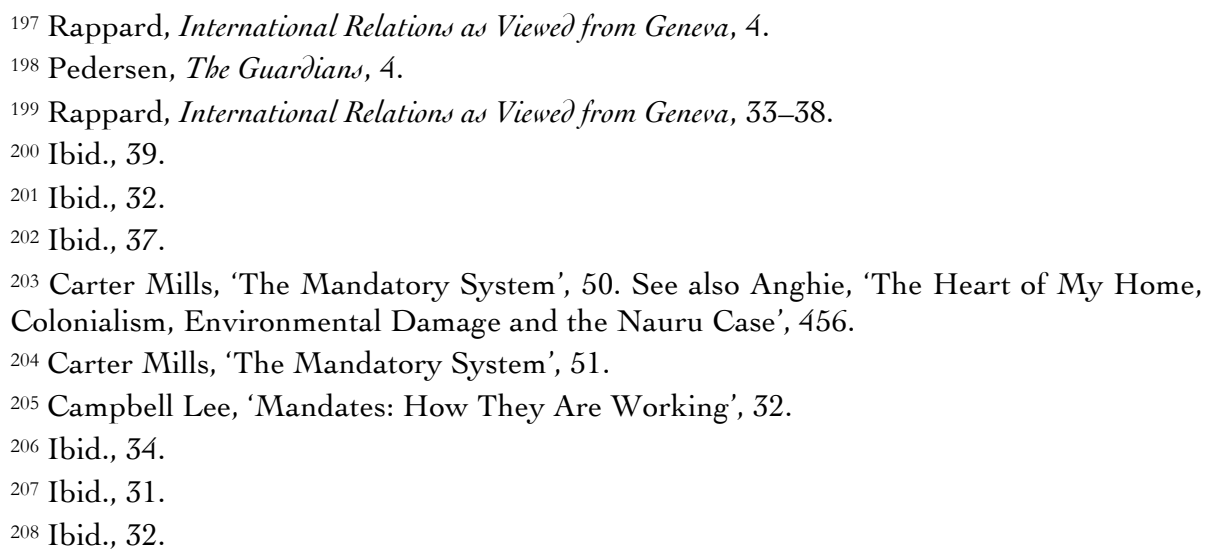


tribal customs, such as cannibalism, had been suppressed. He was optimistic about the reports showing great advancement in these territories:209 "Reports from year to year show that the Mandatories are promoting to the utmost the material and moral well-being and the social progress of the native peoples", he said. ${ }^{210}$ As examples he told that slave trade had now ended, there was adequate remuneration for labour, traffic in both arms and liquors was now prohibited, there was a freedom of conscience and worship in the territories and missionaries were allowed to enter and move freely:211 "The black and backward peoples of the earth are now certain to obtain ... a new freedom, a new civilisation; and all in harmony with the best traditions of the British Empire." 212 Of course, there were problems and concerns, but that was quite natural when peoples possessing a lower culture had to adapt themselves to the new state of things, or accept a new subordinate position in their own country.213 Here he referred to the Palestinians and their mandate. He compared the achievements of the British in Palestine to the miserable French administration in Syria, and was convinced of the superiority of British administration. ${ }^{214}$

Though many British authors saw similarities between British colonial policies and the mandates, Quincy Wright noted that the British Empire had become a means for self-determination gradually, whereas the League of Nations was that from the beginning. He had agreed with Palacios, a member of the Permanent Mandates Commission, who had noted that "the emancipation of the territories under mandate was, or ought to be, the normal goal of their development". 215 According to the League Covenant, this applied to all the mandates, but particularly to the A mandates, where it had been formulated explicitly. The purpose of the mandates system according to Wright was the selfdetermination of territories and to provide the means to achieve it. However, this was not easy to accomplish. ${ }^{216}$ Also, the interests of local people were, if not the central focus of the administration, at least to be taken notice of: "It is believed that the system has advantages from the standpoint of the inhabitants of the area and of the world in general over the system of imperial control ... which has characterized the relation of advanced and backward peoples in the Eastern hemisphere, and also over the less precise system of self-determination qualified by the Monroe Doctrine, sporadic interventions, quasi-protectorates, receiverships, and occasional annexations by the United States ... ."217

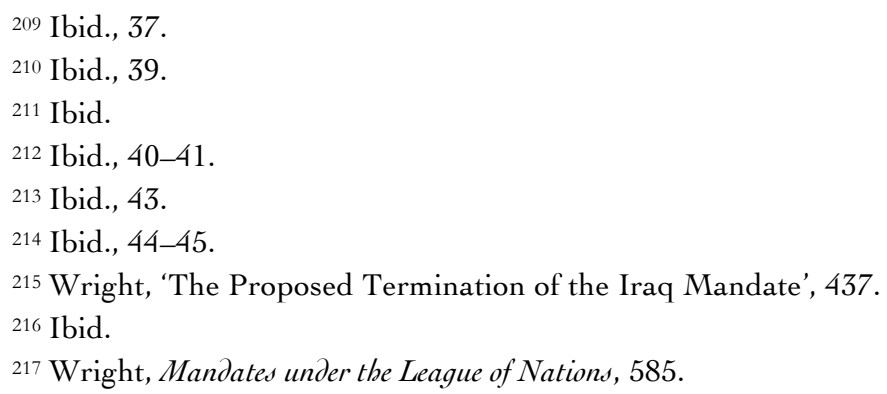


The international lawyer B. A. Wortley's starting point for the mandate system was also trust. For him trust was an ethical concept, "based on conscience and conscionable conduct, a juridical notion closely connected with ideas of morality and public policy". ${ }^{218}$ A trust imposed a moral attitude and a moral duty to the trustee. ${ }^{219}$ However, at the same time he saw another side of a trusteeship, "the holding in trust for the world of those resources it is a duty humanity to develop". ${ }^{220}$ A trust was not to last for ever. It would come to an end when the minor would gain full legal status, and the same applied to the mandates. $\mathrm{He}$ believed that for many this might take a long time to achieve, but nevertheless, everyone had the ultimate right to aim for improvement of their conditions. ${ }^{221}$ As an example of such an attitude he reminded people of Article 23 of the League Covenant, which was against labour exploitation. This article was to protect the weak and the principles were used in the mandate as well. The ideals of the League of Nations showed respect for the human personality which was based on the humanist thinking of Vitoria and Grotius. ${ }^{222}$

Chowdhuri and Hall, the leading interpreters during the 1950s, still operated in the colonial paradigm of the white man's burden, the ethical responsibility for the less fortunate. Chowdhuri describes the language of the Covenant as more emotional and humanitarian than legal or parliamentary. Trust did not have any legal meaning in the Covenant (which several decades later let the judges of the ICJ make very different opinions on the responsibilities of the mandatories towards the mandated areas and their peoples).223 Chowdhuri described the mandates as the "foundation of enlightened self-interest". ${ }^{224}$ According to Hall, an international organization would better act as a conscience towards the natives than an individual state. Nevertheless, he believed in the existence of a national conscience as well, which was apparent in humanitarian (e.g. anti-slavery) movements. ${ }^{225}$ Duncan Hall also interpreted the "sacred trust" in the context of Lugard's Dual Mandate. However, he did not elaborate on the meaning of trust, noting that the principle was a general one, and "had in it a large element of haphazard and accident".226

The territories that in the end became mandates were extremely diverse and the plans on their future were similarly diverse. Some authors saw the system mainly as a means to emancipate those countries that were about to become

${ }^{218}$ Wortley, 'Idealism in International Law: A Spanish View of the Colonial Problem', 156.

${ }^{219}$ Ibid., 156-57.

220 Ibid.

221 Ibid., 157.

222 Ibid., 166-67.

${ }^{223}$ Chowdhuri, International Mandates and Trusteeship Systems, 10.

${ }^{224}$ Chowdhuri, International Mandates and Trusteeship Systems, 8.

${ }^{225}$ Hall, Mandates, Dependencies and Trusteeship, 46-47.

226 Ibid., 33. 
independent in the foreseeable future (in practice the territories that were to become the A mandates). However, interest in the mandates focused more on the African mandates. Duncan Hall has claimed that the idea of mandates would be misunderstood if one looks at them only in the African context, as they did not originate mainly in Africa. In his view, looking at mandates mainly from an African point of view has shifted the focus of the history of the mandates to "the humanitarian movement, the abolition of slavery, the development of national trusteeship, colonial self-government, equality of commercial access, the Berlin African Conference of 1884-85, and, finally, the setting-up of the League African mandates". ${ }^{227}$

Duncan Hall saw trust as a universal ethical principle: "If the ethical principles and the code of welfare are valid they are of universal validity." 228 Thus, if due to Article 22 these principles were to be applied to some dependent territories, there was no reason why they should not be applied to other colonized territories as well. Hall found it difficult to distinguish which territories were administered as a sacred trust, and which by some other code of conduct. $\mathrm{He}$ believed that crossing a border from a mandated territory to another territory administered by the same country would not reveal any true difference between these two: "Laws and ordinances, administrative forms, basic ideas and principles, would look much the same on both sides of the frontier." 229 In essence, according to Hall, the Permanent Mandates Commission was working out "the best colonial practice", in the end to be applied to colonies everywhere. ${ }^{330} \mathrm{He}$ maintained that the ethical principles of the mandates system were contagious: "The principles which the Covenant embodies must be taken to extend to also colonies and territories ... . Article 22 in fact means the final repudiation of one system of colonial government and the definite acceptance of another." 231

Of the most recent accounts, Susan Pedersen has argued that the mandates started as a project of imperial reconciliation, but inadvertently shifted into a project where normative statehood became, at least to a certain extent, a real possibility. ${ }^{232}$ Firstly, Pedersen finds that the significance of the mandates system can only be understood if one understands its geopolitical importance. The mandates were established at a time when British and French imperial interests were in need of reconciliation, there was a risk of Germany wanting its share of the colonial wealth, ${ }^{233}$ and a way for American participation in the global political order was required. The mandates were a means to negotiate between the

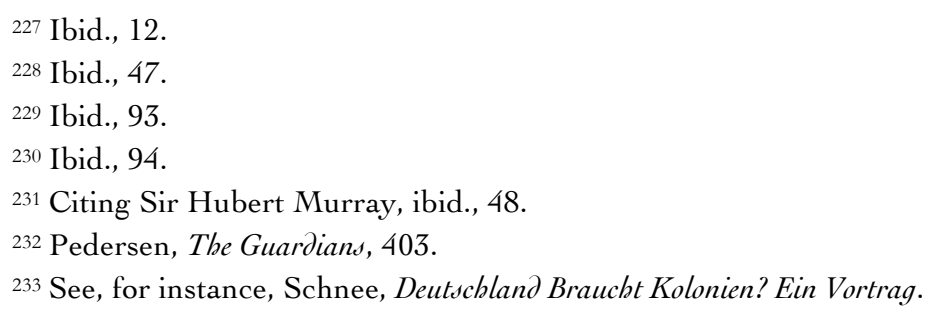


different conflicting demands. Secondly, once the process of internationalization had begun, there was no way of turning back. The League established new norms and new processes through supervision, questioning, accepting petitions and first and foremost, through publicity. These processes became the new standard for colonial administration, even if this had not initially been the plan of the Allied powers. Pedersen finds this interaction between geopolitical interests and international scrutiny to be the most important legacy of the mandates system. The simultaneous coexistence of these two dynamics, colonialism and internationalism, led to unexpected results, opening the way to statehood for dependent peoples. ${ }^{234}$

Similarly, Michael Callahan describes how the mandates system combined the two predominant global forces of the inter-war era, imperialism and internationalism. The vocabulary of "trusteeship" and "sacred trust" enabled the imperial powers to reform their colonial practices in a more humanitarian direction, changing the entire colonial culture and, at the same time, improving their imperial reputation. He finds that international trusteeship created channels for both the European critics of imperialism and the inhabitants of various colonial dependencies to challenge colonial rule. ${ }^{235}$

Anghie, on the other hand, claims that the mandates system brought a distinctive character of non-European sovereignty to those states that had once been mandates. In his view, the ambitions of colonial transformation of the mandates system failed. Instead, the former mandates were left with a vulnerability due to economic inequality that has enabled the continuation of similar processes, not through colonialism as such, but through the interventions of economic institutions, such as the Bretton Woods Institutions, the World Bank and the International Monetary Fund. He claims that these institutions have brought a new civilizing mission, similar to that of the mandates. ${ }^{236}$

Was the mandates system merely a continuation of colonization? I would argue that in many ways it was, especially in the beginning. First of all, it was based on ideas that derived directly from the colonial era. Humanitarianism was not new. Since the $19^{\text {th }}$ century there had been aims to reconcile colonial needs and the welfare and development of the inhabitants of the colonized territories. If news of severe maltreatment of natives reached Europe, it was bound to cause popular outrage and in some cases even lead to changes in colonial administration. ${ }^{237}$ Of course, this by no means meant that the welfare of locals was

\footnotetext{
${ }^{234}$ Pedersen, The Guardians, 405-406. See also Pedersen, 'The Meaning of the Mandates System: An Argument', where she argues that the mandates system was an "arena for political legitimation and political learning", not an administrative system.

235 Callahan, A Sacred Trust: The League of Nations and Africa, 1929-1946, 194-195.

236 Anghie, Imperialism, Sovereignty, and the Making of International Law, 191.

237 The Belgian King Leopold's administration in the Congo serves as an infamous example, where outrage at the maltreatment of the local people led to drastic changes in
} 
always made a priority. The private law metaphor of trust was used by comparing the natives of the mandates to the different beneficiaries of trusts, the natives taking the place of a "minor" or "lunatic". 238 The mandatories accepted an obligation of "binding legal character" towards the international community when accepting the mandate. ${ }^{239}$ However, it has been questioned whether this legal bond also applied to the relationship between the mandatory and the natives, rather than only between the mandatory and the mandated territory.240 At the same time, local welfare was used as an excuse and justification for colonies. It was believed that colonial administration would bring the civilization necessary for living conditions to improve. It was believed that there were certain levels of civilization and that administration by Europeans would help raise the level of civilization in the colonial territories.

This idea found its way into the mandates system as well. The mandatories and the PMC saw themselves as representatives of a higher civilization, whose task was to bring the mandates closer to the level of Europeans, and in the best case reach the standard of civilization where they could be granted statehood. The PMC's suspicion of the readiness of Iraq to achieve independence shows that they could not envision such an event taking place any time soon, if ever.

Yet, there was a will to create a novel, internationally controlled system of imperialism, though of course the Western powers would still in practice be responsible for the control of the system. Though the mandates were intended to fulfil ambitious humanitarian ideals, the practical administration was often no different than the colonial system. Especially countries like South Africa, Australia and New Zealand treated their mandates almost as colonies. On the other hand, the mandates were the result of a will to create something new and better than the colonial governance.

\subsection{The Permanent Mandates Commission and the League Organs}

As the League of Nations set out to administer the mandates, there were important technical issues to resolve. How would the League oversee the mandatories and their government of the territories? For this purpose, an international commission was set up and tasked with supervising the mandates. The Permanent Mandates Commission was staffed by a motley crew of old colonial hands, idealists and reformers. It worked for over twenty years, as long as the mandates existed.

the territory's administration and caused the territory to be handed over to the Belgian state. See Rappard, International Relations as Viewed from Geneva.

238 Knoll, The Legal Status of Territories Subject to Administration by International Organisations, 60.

239 See Hymans report, 1 League of Nations Official Journal (1920), 334.

${ }^{240}$ Ibid.; Makowski, 'La Nature Juridique Des Mandats B et C', 374. 
A Permanent Mandates Commission (PMC) as an expert commission was originally proposed by the British. Its composition was later determined by the League Council. ${ }^{241}$ The members were not to represent their government but were chosen for their individual qualifications and expertise. ${ }^{242}$ The colonial minister of France, Albert Sarraut, was worried that if the members of the Commission did not mainly represent the mandatory states, they would be guilty of rash decisions. However, most of the members did in practice have colonial experience. ${ }^{243}$ According to the constitution drawn up by the Commission, the PMC was to be composed of nine independent experts with the majority being nationals of nonmandatory states. Later the headcount increased to 10 and in addition an ILO expert was present for matters relating to labour issues.244 Membership was permanent and the members could not hold government office at the same time. ${ }^{245}$ They could not be dismissed without the consent of the majority of the League Assembly. ${ }^{246}$ In practice, four members were nationals of mandatory states, four members were nationals of other colonial states and two were members of states with no colonies. The League Assembly decided that one of the members would be female. ${ }^{247}$ There had been a suggestion of a "coloured member", but that idea was quietly abandoned.248 Also, no state presented anti-colonial, radical candidates and Sweden was the only country willing to give their seat to a woman. Chowdhuri has summarized the pros and cons of the PMC membership arrangement. On the plus side, he noted that as a non-political body its authority would derive from its "impartiality, independence, experience and individual competence of its members". ${ }^{249}$ However, on the negative side, the fact that some of the members were nationals of mandatory states, could question its authority: "[T]he independent experts ... have become a somewhat rare species, and more often than not, are either only government agents in disguise or tend to be more popish than the Pope." 250 Members also both held government posts before their Commission membership and returned to government office from their position in

${ }^{241}$ Chowdhuri, International Mandates and Trusteeship Systems, 58.

242 Ibid., 99 and 183; Hall, Mandates, Dependencies and Trusteeship, 178.

243 Pedersen, The Guardians, 60-61.

244 Chowdhuri, International Mandates and Trusteeship Systems, 182; Hall, Mandates, Dependencies and Trusteeship, 178.

${ }^{245}$ Chowdhuri, International Mandates and Trusteeship Systems, 183.

246 Ibid.

${ }^{247}$ Hall, Mandates, Dependencies and Trusteeship, 180.

248 The representative of Haiti in the League of Nations, Dantès Bellegarde, continued to demand for a "representative of the colored races" after a rebellion and massacre of the Bondelswarts in South West Africa. Dedering, 'Petitioning Geneva: Transnational Aspects of Protest and Resistance in South West Africa/Namibia after the First World War', 792.

${ }^{249}$ Chowdhuri, International Mandates and Trusteeship Systems, 185.

${ }^{250}$ Ibid. 
the Commission, which has also raised questions about their impartiality. ${ }^{251}$ On the other hand, Lugard serves as an example of how members did criticize their own countries as well. When Ormsby-Gore left the Permanent Mandates Commission to serve as the colonial minister for the United Kingdom and returned to the commission as a representative of the government, Lugard was, to the others' great amusement, unyielding in his criticism. ${ }^{252}$

The Permanent Mandates Commission was intended to be an advisory body. It examined the reports which were given annually by the mandatory powers. The reports of the mandatories were discussed in front of the Commission, and of these reports the Commission forwarded its recommendations to the League Council. The Commission could not make any binding decisions concerning the Mandates.

Many of the members had long experience in colonial administration. Several also had a legal education, including William Rappard, Daniel François Willem van Rees, Leopoldo Palacios and Pierre Orts. Within the discussions of the Mandates Commission, several figures are prominent. Britain's representative was Lord Lugard, who had a long career in the British colonial administration. While the French representatives were changed regularly and thus made less of an impact, the Swiss member William Rappard, who was both an academic and a diplomat, headed the Mandate Section of the League of Nations and was prominent in the Commission. The Norwegian representative Valentine Dannevig was the only long-time female member of the Commission and, perhaps due to her background as a teacher, often raised issues of education and civilization. Freire D'Andrade, the Portuguese representative, was often a proponent of traditional colonial rule. Leopoldo Palacios, the Spanish representative, who also wrote a book on the mandates, ${ }^{253}$ was vocal in issues on religion.

\section{Lugard}

Lord Lugard, the British representative, had a long career in the British colonial administration. Lugard's career had started as a soldier and adventurer in different parts of Africa, where he was mainly employed by different chartered companies, eg. the Imperial British East African Company and the Royal Niger Company, trekking with caravans of African soldiers, fighting slave merchants and exploring new territories, and eventually, much later than he had wished, ${ }^{254}$ he became part of the British colonial administration in Northern Nigeria. ${ }^{255}$

\footnotetext{
251 Ibid.

252 Hall, Mandates, Dependencies and Trusteeship, 180.

253 Palacios, Los mandatos internacionales de la Sociedad de naciones.

254 Perham, introduction to Lugard, The Dual Mandate in British Tropical Africa, xxxiv.

255 Perham in ibid.
} 
Lugard was a man of action and a pragmatic civil servant. His main legacy in colonial thought is the so-called "dual mandate", of which he wrote a book of the same name in 1922. On the one hand, the book was a justification of Britain's colonies in tropical Africa. ${ }^{256}$ Lugard was an ardent believer in Britain's abilities to govern Africa, as compared to all other nations present on the continent. ${ }^{257}$ Densely populated Britain needed the colonies, and Britain was in his view the most capable nation to take up the task of civilizing. ${ }^{258}$ One of Lugard's interests was slavery, which he fought in different African locations throughout his career. ${ }^{259} \mathrm{He}$ believed that British administration was needed to rid Africa of the problem. The Labour party in Britain had published a pamphlet against the colonies, and Lugard's book was partly an answer to that criticism. On the other hand, it sought to smooth out the contradiction between traditional, self-interested colonialism and new ideas about a more humanitarian approach to the colonies. Hence, the "dual mandate". In Lugard's view, the colonies could be both: they would prove useful to the mother country, but at the same time improve the conditions of the inhabitants of the colonies. ${ }^{260}$ Moreover, this kind of a "civilized administration", combining the two approaches, was the only proper way to go about the colonies in his view. ${ }^{261}$

Lugard has been described as a passionate man and besides his work, he was deeply devoted to his wife Flora. He had originally left for his adventures in Africa after an unhappy love affair, and his wife's inability to live in Africa affected his later career choices. ${ }^{262}$ This conflict between his two passions led to his diplomatic career at the League of Nations, where he was a long-time member of the PMC. The mandates represented well his idea of the dual mandate, and he took his membership in the PMC seriously, even criticizing his country's actions in the mandates. However, he was slightly amused by the initial establishing phases of the mandates, describing the venture as the Allies states, led by President Wilson, giving content to such "catchwords", as "no annexations", "self-determination", and the "open door". ${ }^{263}$ In principle, he did support the mandates, albeit with some reservations. ${ }^{264}$

\footnotetext{
256 Perham in ibid., xxix.

257 Ibid., 5.

258 "Without underrating the great work which France and Belgium are doing, it is to England that Banlieu generously awards the palm in having led the way in the recognition of the responsibility which is inseparable from the rule." Ibid., 58.

259 Perham in ibid., xxxiii.

260 Ibid., 617.

${ }^{261}$ Perham in ibid., xxix; see also Lugard, The Dual Mandate in British Tropical Africa, 18.

262 Perham in Lugard, The Dual Mandate in British Tropical Africa, xxvii and xxxviii.

263 Ibid., 53.

${ }^{264}$ Ibid., 54.
} 


\section{Rappard}

The Swiss member of the PMC, William Rappard, who was both an academic and a diplomat, headed the Mandate Section of the League of Nations from 1920 to 1924 and was thereafter prominent as a member of the Commission. He was a liberal and an internationalist. Together with the Belgian Pierre Orts, he was the only member to work with the mandatory system throughout its lifespan. ${ }^{265}$ Having worked in the secretariat, he knew the mandates system as well as anyone could and had been part of establishing and integrating it with the rest of the League of Nations.266 According to Ania Peter, who wrote his biography in the 1970s, Rappard was supportive of colonialism. He was also sceptical about the attempt to justify colonialism as a humanitarian obligation. She writes that he struggled to understand why one should intervene in disputes between different African tribes, but ignore more close-by actions against injustice, for instance in the Ottoman Empire or Russia. He also believed that the world economy could not do without colonization. However, he claimed that the mandatories had first and foremost a responsibility towards the natives in the mandated territories, and only after that a responsibility towards the international community.267 The national administrators, the mandatories, he excluded from the scope of those whose interests would play a role. ${ }^{268}$ Rather, they were "servants more than masters". ${ }^{269} \mathrm{He}$ continuously stressed the disinterested governing of the mandates. Like Dannevig, he used the rhetoric of tutelage, often comparing natives to children. The disinterested nature of the duties of the mandatories was thus natural, as it needed to be compared with the duties of guardians and their wards. ${ }^{270}$ The mandatory powers were to "pursue their 'sacred mission of civilization' of guiding their minor wards on the road leading toward selfgovernment" 271 "pending the coming of age of the minor whose education is to be completed" 272 and the interests of the "wards" were not to be "sacrificed to the jealousies of the guardians" 273 . In his view, the entire mandate system rose out of a compromise between American antipathies to colonialism and European empires. He pointed out that Wilson was part of the American tradition in his hostility towards annexations, whereas members of the British Empire wanted the territories for themselves. ${ }^{274}$ The mandates were the compromise between these

\footnotetext{
265 Peter, William E. Rappard Und Der Volkerbund, 133.

266 Ibid.

267 Ibid., 134-39; Rappard, 'Mandates and Trusteeships', 52.

268 Rappard, 'Mandates and Trusteeships', 521.

269 Ibid., 523.

${ }^{270}$ Rappard, 'The Mandates and the International Trusteeship Systems', 410.

271 Ibid., 409.

272 Rappard, 'Mandates and Trusteeships', 523.

${ }^{273}$ Rappard, 'The Mandates and the International Trusteeship Systems', 415.

${ }^{274}$ Rappard, 'Mandates and Trusteeships', 521.
} 
two conflicting pursuits, "disinterested humanitarianism and acquisitive nationalism", and in his view a successful one. He saw the mandates system, and also the UN trusteeship system after that, as a way to improve colonialism, to change the focus of colonialism from self-interest to the inhabitants themselves. ${ }^{275}$ Only Japan, he complained, did not play by the rules of the game. ${ }^{276}$ Rather, there was a "veil of ignorance and misunderstanding" between the Japanese and the PMC because of "distance, language, official discretion, and undoubtedly also deliberate policy". He admired his colleagues at the PMC and credited mainly them for the successes of the mandates. He described them as "experienced", deserving of the "respect and confidence" of the international community, men [sic] with "conscientious attention and a real zeal". ${ }^{277}$ His own task "as a mere Swiss professor" was, in his own words, "a very modest one". 278

\section{Dannevig}

The Norwegian representative Valentine Dannevig was the successor of the Swedish Anna Bugge Wicksell, and served in the Commission from 1927 to 1939.

The feminist movement was interested and active in the establishing of the different League institutions and sought to include women in its decision-making processes. Dannevig was one of the few women in visible positions in the League. In a way, Dannevig embodied the dual character of paternalistic colonialism and benevolence of the entire mandates system. Being Norwegian, she was one of the PMC members from a non-mandatory state. She was originally a schoolteacher, and her interest in education was apparent in her conduct during the PMC meetings. She was one of the liberals of the PMC, together with Lugard and Rappard. In her questioning, apart from questions of education, she paid much attention to girls and women. Her interest involved international feminist concerns, including the trafficking of women, the treatment of women in colonies in general, age of marriage, and other issues relating to marriage, including polygamy. She also took an interest in the electoral laws in Palestine, which would have restricted the elections to men. ${ }^{279}$

Dannevig did not criticize colonial rule as such, but wanted to improve the administration through her active questioning of the representatives of the different mandates about social conditions. ${ }^{280}$ Dannevig regarded the natives as children. In her world, ideal administration centred around education and the improvement of native conditions. She was not tolerant towards rebels, regarding

\footnotetext{
${ }^{275}$ Rappard, 'The Mandates and the International Trusteeship Systems', 413.

276 Ibid., 410-12.

277 Ibid., 410.

278 Ibid., 412.

279 Pedersen, 'Metaphors of the Schoolroom'.

280 Ibid., 195.
} 
them as misbehaving schoolboys who needed a change in attitude and disciplinary reprimand rather than anything else. In such instances she did not criticize the mandatories for suppressing the rebellions. However, she did not tolerate the mandatories' various explanations about why the social standards of the natives could not be improved. ${ }^{281}$ In general, the natives, like children, could be controlled through "prestige, example or love". 282

\section{D'Andrade}

The Portuguese Alfredo Augusto Freire D'Andrade had a long career in Portuguese Africa, where he had acted, among other things, as Governor General of Mozambique. ${ }^{283}$ Being very much a son of the Portuguese colonial tradition, he was often a proponent of traditional colonial rule. D'Andrade was among the loudest members of the PMC to tout the supremacy of the white minority population in Africa and the duty of the administration to keep the black majority obedient. ${ }^{284}$ Like many Social Darwinists, he believed in the existence of strong and weak races. ${ }^{285}$ D'Andrade believed that the fact that a community would disappear simply meant that it was not fit enough for survival and civilization. ${ }^{286}$ D'Andrade saw well-being from an economic point of view: development meant economic development. ${ }^{287} \mathrm{He}$ saw African men as naturally lazy and therefore encouraged compulsory labour in order to achieve the economic progress necessary for carrying out the sacred trust.

$$
* * * * *
$$

The inner tensions within the Permanent Mandates Commission were not necessarily revealed to the world outside but were nevertheless present, and also clearly visible in the published minutes of the PMC.288 The question whether petitioners would be heard serves as an example. ${ }^{289}$ The division on petitions was clear: the French mandatory administrations were hostile to petitions in general and certainly did not want petitioners to participate in oral hearings. The French members of the PMC echoed this, not hiding their distaste about the possibility of

\footnotetext{
281 Ibid., 200.

282 Ibid., 197.

283 Pedersen, The Guardians, 61.

284 See e.g. ibid., 123.

285 Blackburn, The American Crucible: Slavery, Emancipation and Human Rights, 387.

286 See Minutes 7 (1925), 202-203; Anghie, Imperialism, Sovereignty, and the Making of International Law, 161.

287 Ibid.; Pedersen, The Guardians, 131.

288 See chapter 3.

289 Discussed in chapter 4.
} 
having to hear oral complaints from the "Orientals". ${ }^{290}$ Yet, the rest of the PMC believed that petitions were an essential part of the mandatory system. Particularly the Italian Theodoli used his position as chairman to irritate both the British and the French administrations. First of all, it was his task to determine the "receivability" of the petitions, and he used this power to let through petitions that would have otherwise been rejected due to "violent language" or the fact that the petition would have rather belonged to local courts. He also distributed petitions to rapporteurs that he believed would be sympathetic to the complaints and thus increased the possibility of their acceptance. ${ }^{291}$ Similarly, the question of native welfare revealed a wide division in the ideals of Lugard and D'Andrade, the latter showing Darwinist ideas about the survival of the fittest communities and no regret about the dying out of the weaker ones, while Lugard stressed the duty of the mandates system to increase the welfare of all native communities. ${ }^{292}$ Lugard and D'Andrade had several heated debates on the issue, which led to them writing memoranda at Theodoli's suggestion to air their disagreements. ${ }^{293}$

The Permanent Mandates Commission worked in an atmosphere of conflicting needs and expectations. For the sake of credibility, it needed to be neutral, but on the other hand, for practical reasons and the ability to work, it called for the support of the mandatory governments. As the PMC required the support of the mandatories, it also needed to assure that they were not "judges in their own cause". ${ }^{294}$ It solved this contradiction by including the mandatory states as parts of the commission and having the accredited representative present when the reports of the relevant mandate were discussed. The representative, however, did not have the right to vote. ${ }^{295}$

The working of the Permanent Mandates Commission evolved through the years to include tasks and powers which were not intended originally. The League Covenant did not contain the right to petition. However, in 1923 a resolution was adopted by the League Council that allowed petitions. ${ }^{296}$ The inhabitants had to submit the petitions through the mandatories to be subsequently considered by the

\footnotetext{
290 Pedersen, The Guardians, 84.

${ }^{291}$ Ibid., 85.

292 This is discussed in more detail in section 3.4.

293 Pedersen, The Guardians, 131; Minutes 7 (1925).

${ }^{294}$ Hall, Mandates, Dependencies and Trusteeship, 158-59.

295 Ibid.

${ }^{296}$ League of Nations, The Mandates System: Origin, Principles, Application, 38. The British had proposed the right to petition in the mandates. They had a similar system in their dependencies and had suggested to include petitions in the Covenant of the League of Nations. From the League's point of view, the petitions worked as a means for the inhabitants of the mandated territories to express their dissatisfaction. Simpson, Human Rights and the End of Empire: Britain and the Genesis of the European Convention, 147; 4 League of Nations Official Journal (1923), 200, 3 League of Nations Official Journal (1922), 1176 and 1245; Hall, Mandates, Dependencies and Trusteeship, 314-315; Pedersen, The Guardians, 78 onwards.
} 
Permanent Mandates Commission. The minutes of the Mandates Commission were public, which according to Rappard led to one of the greatest influences of the Mandates Commission, namely transmitting knowledge of the mandated territories and thus affecting public opinion. ${ }^{297}$

The most important source of information for the PMC were the annual reports by the mandatories. ${ }^{298}$ The members had to work at considerable distance from the actual mandates and react after a delay when the reports were discussed in Geneva. ${ }^{299}$ The members of the Commission developed a quick eye in finding shortcomings and inconsistencies in the reports. ${ }^{300}$ The reports were published by the governments and the League of Nations did not even make summaries of them. ${ }^{301}$ There was more tension between the PMC and the administration of the $\mathrm{C}$ mandates than the other administrations, and it was more difficult for the PMC to gain information from the $\mathrm{C}$ mandates than from other territories. The representatives of the $\mathrm{C}$ mandates mainly resided in London or Geneva, and thus would not be able to bring first-hand knowledge from the mandates. ${ }^{302}$

The contents of the report were based on a questionnaire, drafted by the PMC. The different "guarantees", such as slavery, liberty of conscience, etc. discussed in the reports, were all mentioned in the questionnaire. Also, all legal and administrative decisions made during the relevant year were added into the report. ${ }^{303}$ In 1926 the PMC left the Council a suggestion of a broader questionnaire and a proposal for hearing petitioners orally. ${ }^{304}$ Here the mandatory governments in the Council considered that the power of the Commission was becoming too wide and the questionnaire too inquisitorial. 305

Throughout the years, the PMC developed a mode of work that could be called both supervision and co-operation. 306 The PMC exerted a small degree of pressure by posing expert questions, rarely criticizing and often praising (especially if it criticized). ${ }^{307}$

Hall viewed the PMC as a "remarkable body", with no precedent, whose members were able and competent. As mention was made of the PMC in the

\footnotetext{
297 Rappard, 'Human Rights in Mandated Territories', 118. Susan Pedersen maintains that one of the greatest significances of the mandates system was the publishing and distributing of records and reports, which resulted in discontent, "the uncontainable wave of scrutiny and 'talk'", being made public information. Pedersen, The Guardians, 406.

${ }^{298}$ Hall, Mandates, Dependencies and Trusteeship, 186.

${ }^{299}$ Ibid., 50-51.

300 Ibid., 188.

301 Ibid., 189.

302 Ibid., 197.

303 Ibid., 191.

${ }^{304}$ On the oral hearing of petitioners, see section 4.3 below.

305 Hall, Mandates, Dependencies and Trusteeship, 191 and 203.

306 Ibid., 207. See also Minutes 8 (1926), 200.

307 Ibid.
} 
League's Covenant, it was out of the question for the mandatory governments to dissolve it. ${ }^{308}$ As reasons why he deemed it a success, Hall noted that: "A commission made up of individual members, debating in the seclusion of a room at Geneva and unable to study conditions at first hand in the mandated areas, might indeed have degenerated easily into a doctrinaire body engaged in endless discussions of questions of theory. It was saved from this by the practical experience and good sense of its members, as well as by their continual contact with responsible officials from the territories themselves." ${ }_{09}$ The PMC accepted different methods of administration and did not try to unify the territories, but saw that "the well-being and development of such peoples" can be achieved through different kinds of methods. ${ }^{310}$ The PMC was able to reach its goals during its 20 years of existence without major conflicts and crises. According to Lugard, the secret of its success was that it did not criticize and refrained from giving overly direct advice, and while all members had the right to speak out, and their views were recorded in the minutes, all the differing views did not bind the commission and the neutrality of its members was respected. The PMC became more independent than anyone would have imagined in its early years. Susan Pedersen explains this as the result of the members' strong positions in the colonial administrations of their respective countries and especially their expertise in the colonies. This meant that they were difficult to control. Also formal matters, such as the term being fixed, their authority being based on League of Nations documents and the fact that their deliberations were published, strengthened their position. 311 However, the French members differed from the rest by openly protecting the interests of France. ${ }^{312}$

The League of Nations Council consisted for a great part of states holding mandates and this had an obvious effect on its relations to the Mandates Commission. Particularly during the early years, the Council was sceptical of the Commission's work. ${ }^{313}$ The League of Nations Council had the duty of making final decisions on the mandates and receiving the reports of the mandatories. Besides the permanent members of the League Council, all the remaining mandatory powers in 1923 were invited to participate in the discussion of the mandates question by the Council.314 According to Article 22, the Council appointed the members of the PMC, received annual reports of the mandatory powers, endowed the Commission with a constitution and rules of procedure, made appropriate observations to the mandatory powers on the basis of the PMC

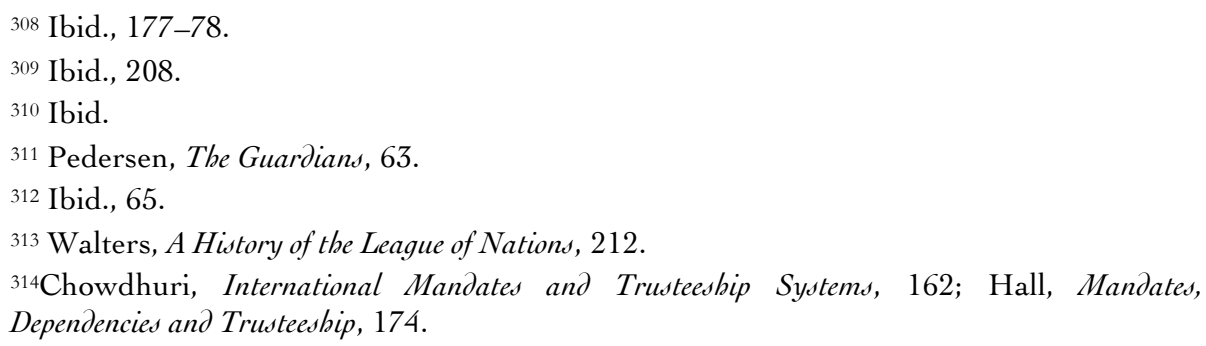


reports, modified or amended the terms of the mandates and determined the requisite conditions for the termination of a mandate. ${ }^{315}$ Throughout its life, the Council made only unanimous decisions on the mandates. ${ }^{316}$

Article 22 makes no reference to the League Assembly. ${ }^{317}$ The Assembly included all member states of the League and was supportive of the Mandates Commission's work. The Assembly had a majority of non-colonial powers and they used the mandates as an opportunity to criticize the colonial governments. Criticism in the Assembly would receive wide publicity, which made it a useful political weapon. ${ }^{318}$ In the early years there was a controversy about the role of the Assembly relating to the mandates. The first Assembly claimed that they had the right to discuss mandates, but this was declined. Lord Balfour stated that the responsibility was only the Council's: "if this catastrophe were really to arise ... the future of the League of Nations was profoundly imperilled". 319 According to Chowdhuri, the controversy led to the fact that even when in the end the Assembly did gain the right to discuss mandates as part of its general competence, this right was rarely exercised: "The League Assembly limited its action to the routine consideration of the section of the Council's annual report dealing with the Mandates through its Sixth (Political Committee) ... [and] adopted resolutions, courteously worded." 320 However, Hall gives a very different account of the actions of the Assembly relating to the mandates: "It added, not infrequently, recommendations relating to particular questions such as the Bondelzwarts incident in South West Africa (1922), particular situations in Palestine or Syria, or questions like the liquor traffic in the ' $\mathrm{B}$ ' and ' $\mathrm{C}$ ' mandates." ${ }_{21}$ The Assembly also discussed the annual Secretary General's report.

One of the reasons for the frustrating position of the Mandates Commission was that it had to be careful not to undermine the authority of the administration in the territories, either in front of the natives or the League of Nations member states. For that reason, it very rarely opposed anything that the mandatory powers did. The mandatories were hostile to the hearing of petitions in front of the Commission and were also antagonistic towards the Commission's enquiries about the mandated territories. The mandatory powers believed that their authority in front of the natives would be endangered if the Commission took too active a role in the administration of the territories. In their view, the presence of the Commission in the mandated territories, or the presence of the petitioners in front of the Commission together with the mandatories would put the Commission in

\footnotetext{
315 Chowdhuri, International Mandates and Trusteeship Systems, 164.

316 Hall, Mandates, Dependencies and Trusteeship, 175.

317 Chowdhuri, International Mandates and Trusteeship Systems, 147.

318 Hall, Mandates, Dependencies and Trusteeship, 170-73.

${ }^{319}$ Chowdhuri, International Mandates and Trusteeship Systems, 147-48.

320 Ibid.

${ }^{321}$ Hall, Mandates, Dependencies and Trusteeship, 170-73.
} 
the role of a court which was to decide between the view of the mandatory and the view of the native. Nor should the Commission provoke complaints that were not justifiable from the mandatories' point of view. In most cases, the Commission behaved towards the mandatories in a polite, patient and encouraging manner. The mandatories were congratulated whenever the Mandates Commission found reason to do so. The Commission did, however, question the mandatories whenever it found it necessary, and particularly worrying questions were brought up year after year. There was also direct criticism towards the mandatories, particularly South Africa, as the Commission grew suspicious that South Africa was attempting to annex South West Africa into its own territory. ${ }^{322}$

Like the mandates system itself, the Mandates Commission set to administer it was a mix of liberal idealism and old colonial practices. Its members were independent experts who had been nominated by their countries. One sign of the influence of liberal ideals was that one of its members was to be a woman. The composition was a mix of old colonial officers and idealists. Sometimes these could be one and the same person, like Sir Frederick (later Lord) Lugard, one of the chief ideologists of British indirect rule. As an advisory body that relied chiefly on the reports of the mandatories themselves and without the power to issue binding rulings, the Commission had a weak official position in relation to the mandatories. The power of the Commission and its importance lay in its ability to make public concerns about the administration of the mandates. An integral part of this power was the system of petitions, which it used to exert pressure on the mandatories.

322 Minutes 31 (1937), 44: "The Chairman recalled that the Administration of the territory had often in the past earned high praise from the Mandates Commission. The latter therefore now felt all the more free to express a somewhat less favourable judgment." 


\section{Themes: A Reading of the Minutes of the Permanent Mandates}

\section{Commission}

\subsection{Introduction}

In his book International Law and Human Righto (1950) Hersch Lauterpacht saw the mandates as part of the gradual change in the position of the individual in international law. While not being subjects of international law, he wrote that individuals possess a certain procedural capacity. He pointed out, for instance, that the League of Nations Minorities Treaties created rights and duties between the signatory parties and thus did not constitute, according to the doctrine of the time, direct benefits for the individual. The treaties did not create individuals as subjects of international law. He, however, believed that the matter was not so black and white, as the treaties created "some procedural status" for the minorities. Even more so, he noted, "this was also ... the position in relation to the inhabitants of mandated territories". Lauterpacht did not view the mandates system as a human rights system. He discussed the Charter of the United Nations as the "innovation" where "the individual human being first appears as entitled to fundamental human rights and freedoms". ${ }^{1}$ He acknowledged the existence of an "occasional recognition of some fundamental human rights in treaties providing for religious freedom and the cultural and political rights of minorities", providing the Minorities Treaties as an example. ${ }^{2} \mathrm{He}$ did not mention the mandates in this context. Thus, for him, the significance of the mandates was processual. They included the right to petition, which he argued was a natural right and should be included in the post World War II International Bill of Rights. ${ }^{3}$ The rights granted to the inhabitants of the mandates were part of a gradual shift in the position of the individual in relation to international law, which would culminate in the post World War II human rights treaties.

In this section, I will be following the emergence of rights language in the minutes of the Mandates Commission during the years 1921-1939. As I have discussed in the introduction of this study, I will examine discussions of the PMC on land tenure, the obligations that newly independent territories would have, the eradication of slavery, the issues of forced labour, the position of women and the liberty of conscience as arenas of proto-rights language.

The questions that I have chosen to study are those that could also be looked at from the point of view of the individual. Each of these issues has the potential to improve the position of the individual and have been looked at as such at some moment in history. All of the questions that have been studied here concern the relationship between the individual and the administration, not only the

\footnotetext{
${ }^{1}$ Lauterpacht, International Law and Human Rights, 33.

2 Ibid.

${ }^{3}$ Ibid., 244 and 337.
} 
mandatory administration, but also the PMC as the institution supervising this relationship. Through the mandates instruments the mandatories had taken the duty to "safeguard the interests of the natives", for instance by giving certain guarantees concerning these different "rights". Similarly, through receiving reports and formulating the questionnaires, the PMC guided each of the mandatories to report on its actions regarding these issues.

Despite the vast differences between the three types of mandates (A, B and $\mathrm{C})$, in most cases the mandates have been studied together. In questions such as slavery or the position of women, the PMC discussed the different types of mandates in a very similar way. However, in the case of freedom of religion, the PMC's emphasis was different in the A mandates when compared to the B and C mandates. In Palestine, the aim to achieve peaceful coexistence between the Muslim and Jewish groups demanded most of the PMC's attention. In Syria and Iraq, the PMC's attention focused on the position of Christian minorities. In the B and $\mathrm{C}$ mandates, the emphasis was different. The Cameroons had a large Muslim population, whose customs the PMC took into consideration, but at the same time it accused the Muslims of "uncivilized" practices, such as polygamy and slavery. In the other territories most of the discussions related to the various missions and their mutual relationships, but every now and then they touched upon native religions and their customs as well.

In the terminology of the early $20^{\text {th }}$ century, the "rights" of individual people usually meant civil rights as opposed to human rights. In $19^{\text {th- }}$ and early $20^{\text {th }}$ century Europe civil rights were linked to nationality and citizenship. For this reason, they were not provided for in the colonies. ${ }^{4}$ In the mandatory system, the civil rights of the various groups of inhabitants, similar to those granted in European constitutions, were granted in the A mandates. For instance, the organic law of the mandate of Palestine declared that: "The Mandatory shall be responsible for placing the country under such political, administrative and economic conditions as will secure the establishment of the Jewish national home, as laid down in the preamble, and the development of self-governing institutions, and also for safeguarding the civil and religious rights of all inhabitants of Palestine, irrespective of race and religion" (Article 2). The organic law of Iraq provided for the personal freedom of all Iraqi dwellers, prohibited torture and the exile of Iraquis (sic) outside the Kingdom of Iraq, safeguarded the rights of ownership, and free expression and assembly. ${ }^{5}$

Such rights were, however, left outside the competence of the PMC. As the PMC discussed the "receivability" of petitions from the mandates, the Commission concluded that petitions on matters that could be referred to local courts could not

\footnotetext{
${ }^{4}$ Hoffmann, 'Introduction. Genealogies of Human Rights', 9-10; Moyn, The Last Utopia: Human Rights in History, 30, 37-38.

${ }^{5}$ Organic law of Iraq, part I, paragraphs 7, 10 and 12.
} 
be considered receivable. These would include "ordinary civil rights". ${ }^{6}$ The PMC deliberately did not want to act as a Court of Appeal. Of course, it was difficult to distinguish between questions justiciable in the local courts and those that "refer to questions of policy or of administrative or executive action on the part of the local officials of the Mandatory Power in regard to which the petitioner has no means of redress". ${ }^{7}$ Such rights, particularly concerning legal or religious discrimination in the different communities, were debated before local courts. ${ }^{8}$

The petitions originating from Palestine revealed the limitations to civil rights. The Arab population complained that they were perhaps granted civil rights, but political rights were out of their reach. There was no intention by the League to give them the right to affect the political status of the area. ${ }^{9}$

While the PMC considered the interpretation of any clauses containing civil rights to be the task of local courts, it was interested in their existence in the constitutions of the A mandates. However, as regards the substance of such rights, the PMC's interest circled around the situations of minorities. ${ }^{10}$ The A mandates were at least to a certain extent seen to be on a path towards self-determination. Thus, it was part of the task of the PMC to see that they had constitutions

${ }^{6}$ Wright, Mandates under the League of Nations, 171.

${ }^{7}$ Lugard note, Minutes 4, Annex 6 (1924), 178.

${ }^{8}$ For instance, the Supreme Court of Palestine held in 1925 that an ordinance enacted by the High Commissioner for Palestine, authorizing the Municipality of Jerusalem to take water from a neighbouring village to increase the water supply of Jerusalem, was contrary to Article 2 of the mandate. The mandatory's duty "for safeguarding the civil and religious rights of all the inhabitants of Palestine, irrespective of race and religion" was not fulfilled as the villagers had not been provided full compensation. However, the British Privy Council turned down the decision as in their view Article 2 only prohibited discrimination that had not taken place in this case. District Governor, Jerusalem-Jaffa District and Another v. Suleiman Murra and Another. Supreme Court of Palestine. 25 June, 1925. Judicial Committee of the British Privy Council. 16 February, 1926. 3 ILR (19251926) 46-47.

In 1928 the Palestine Supreme Court held that a bye-law restricting only the opening hours of Jewish establishments on the Jewish Sabbath Day on the grounds that it was discriminatory "against the Jews that the bye-law makes a discrimination in favour of the very small minority in the area of the Local Council." One judge, however, dissented, noting that instead of being discriminatory, the bye-law merely granted a privilege to the Muslim and Christian populations on the ground of their religion. Attorney-General $v$. Abraham Altshuler. Palestine Supreme Court, May 1928. 4 ILR (1927-1928) 55-56.

In a case concerning the choice of the correct religious law to rule on the succession to the movable property of a deceased person, the Court of Appeal of Aleppo in Syria concluded in 1928 that "[t]he Mandate for Syria and Lebanon provides that the Mandatory shall introduce a judicial system which shall assure to the natives as well as to foreigners a complete guarantee of their rights." Thus, as the deceased belonged to the Christian population, his family was entitled to have his matters regulated according to Christian law. Succession of Rizcallab Gazalé Case. Court of Appeal of Aleppo, Syria, 7 May, 1928. 4 ILR (1927-1928) 95-96.

9 Wheatley, 'Mandatory Interpretation', 240; Pedersen, The Guardians, 388.

${ }^{10}$ See e.g. Minutes 33 (1937), 21 on the constitution of Syria. 
including rights "granted ... by organic laws of all civilized countries". ${ }^{11}$ These rights were, however, based on the citizenship of the people, and in the case of minorities there was a genuine fear that minorities would remain outsiders. ${ }^{12}$

The rhetoric of freedom and promises given to the people in the mandated territories, particularly in the A mandates, to have more say in their own matters, had been used during World War I to justify the war and to persuade inhabitants of colonies to participate in the war. Especially Wilson argued that the right to self-determination was one of the main reasons why the war had been fought. ${ }^{13}$ During the Paris Peace Conference President Wilson declared that “... to hand over distinguishable [?] people to a Mandatory in perpetuity and to say: 'You never shall have a voice in your future; you are finally disposed of,' would be contrary to the principles of that Conference and contrary to the principles of self determination accepted by it". ${ }^{14}$ Nationalist mobilization took place in several colonies, and in the mandated territories it was particularly visible in Syria and in Samoa. ${ }^{15}$ The Syrians in particular were disappointed with the establishment of the mandates. They had had high hopes for self-determination and detested France's presence as a mandatory, not least because France had ousted Syria's old government. Now the Syrians felt that the promises made by the League Covenant had been broken. ${ }^{16}$ In Samoa a movement called "Mau" had long been in conflict with the New Zealand administration. Pedersen describes the reactions of the PMC to the Mau movement and its demands of self-determination as paternalistic. The inhabitants of Samoa were deemed immature and difficult and thus it was the administration's task to keep order and protect them. ${ }^{17}$ Their status as a $\mathrm{C}$ mandate had in itself declared them not ready for self-determination and therefore the PMC was not ready to consider any opposite arguments.

The PMC gave conflicting signals of whether it thought that the idea of the mandates system was to provide for self-determination for all mandated territories, or only for the A mandates. The PMC agreed that the Covenant was clear on the fact that the A mandates were of a temporary nature and were to become independent "at some future date". ${ }^{18}$ The fate of the $\mathrm{B}$ and $\mathrm{C}$ mandates was more complex and as the independence of the first mandated area, Iraq, brought about a debate on the general principles of granting independence to a mandate, it was only natural to discuss whether these principles concerned the $\mathrm{B}$ and $\mathrm{C}$ mandates at all. As the PMC had been given a task to study the conditions of independence by the League Council, the PMC believed it had two options: to follow Chairman

\footnotetext{
${ }^{11}$ Ibid.

12 Moyn, The Last Utopia: Human Rights in History, 12-13.

${ }_{13}$ Anghie, Imperialism, Sovereignty, and the Making of International Law, 138-39.

${ }^{14}$ Miller, Drafting of the Covenant, Vol. 2, 197.

15 Pedersen, The Guardians, 191.

${ }^{16}$ Pedersen, The Guardians, 3, 148-149.

17 Ibid., 179-81.

${ }^{18}$ Minutes 1 (1921), 19.
} 
Theodoli's suggestion that they would study only the A mandates as it was not possible to foresee the end of the $\mathrm{B}$ and $\mathrm{C}$ mandates, or, to follow De Penha Garcia's view that the $\mathrm{B}$ and $\mathrm{C}$ mandates could not be left entirely out. Firstly, he noted, the A mandates were so different that one could not speak of them even in general terms. Secondly, due to Article 22, "the possibility might well be contemplated of a country whose civilization was very different from Western civilization but which might be able to give sufficient guarantees to ask for emancipation, it being understood that that emancipation would not compromise the peace of the world and that, within limits in proportion to its civilization, the country would be capable of ruling itself. He did not think that this was a purely hypothetical case". ${ }^{19}$ Yet, "[h] e was certain that the time for the cessation of B and C mandates was still far off”. ${ }^{20}$ In a note that Van Rees wrote about the general conditions to be fulfilled before the mandate regime could be brought to an end, it is likely that he sums up the thoughts of the majority of the PMC. While it was true that the Wilsonian principles of non-annexation and self-determination applied to the entire mandates system, and while the wording of Article 22 refers to a "temporary incapacity" of self-government (which Van Rees uses as a synonym for self-determination) and it is clear that the Peace Conference anticipated that one day all the mandates would win independence, "[i]n the case of the African and South Pacific territories, this goal is beyond dispute still so remote that it would be safe to say that it is really no more than of theoretical interest". 21

As Susan Pedersen demonstrates, in practice the PMC did not show that it accepted that the right to self-determination was extended to all mandated territories. Instead, it used the language of tutelage to deem the mandates perpetual minors who would need guidance and education for eternity. The PMC would accept the silencing of nationalist movements as long as the mandatories would present that as minors, the mandated peoples could not possibly understand their own best interests. ${ }^{22}$

I have chosen to study the following themes in the deliberations of the Permanent Mandates Commission.

In the chapter on religion I have looked at how the clause in the mandates granting freedom of religion was understood by the permanent mandates commission. Was it seen as granting true freedom of religion to local religions, or was it merely a continuation of the idea to protect Christianity in foreign territories? The limitation clause included in the B and C mandates gave the PMC the possibility to interpret freedom of religion in almost any manner they wished. The PMC strove to provide for genuine freedom of religion to the local religions,

\footnotetext{
${ }^{19}$ Minutes 19 (1930), 155.

${ }^{20}$ Ibid.

${ }^{21}$ Minutes 20 (1931), 197.

22 Pedersen, The Guardiand, 191.
} 
but at the same time would not disguise their preference for Christianity. At the same time, the division between native religions and Christianity was also a division between tradition and modernity. How would the PMC balance between preserving the traditions and modernizing the territories? Also, the PMC needed to balance between preserving native religions and granting the religious rights of the many different Christian missions that existed in the mandated territories. Would the PMC give preference to either one? In the A mandates matters were different and the PMC's task was to ensure an even treatment for all religious communities in the territories.

In the section on slavery I look into whether the process that had started as the anti-slavery movement in the early $19^{\text {th }}$ century had evolved during the mandates period. How was slavery approached by the PMC? Was it a tragedy perceived by the individual or a societal or civilizational question?

It has been claimed that the abolition of slavery and the slave trade was the first human right or human rights movement. ${ }^{23}$ Therefore I have looked into the discourse used by the PMC to see whether they viewed the prohibition of slavery through rights language, or whether there was any other motivation instead of, or in addition to, the individual right to freedom of the populations in the mandates. The discussions show that the abolition of the slave trade and slavery was the result of a mix of motivations such as paternalism, moral superiority, preserving racial hierarchies, civilization, but also genuine benevolence.

Fair working conditions were provided by Article 23 of the League Covenant, forced labour was prohibited in the separate mandates agreements, and Article 421 of the Versailles Treaty required the application of ILO labour conventions in colonies as well. Thus, guarantees for fair labour conditions were provided for by three international instruments. Here I have looked at how these instruments were applied in the mandates. The PMC was almost unanimous about the necessity to abolish forced labour (here D'Andrade is an exception, emphasizing the educational aspect of labour), but as with slavery, it was difficult to find out whether there was actually forced labour in the mandates. The PMC needed to interpret the clauses by drawing the line between legal and prohibited forms of labour, including traditional forms of labour ordered by village chiefs and labour levies. Through labour the PMC was required to find an appropriate balance between the well-being of the people and the economic development of the territory.

The mandatories of the $\mathrm{B}$ mandates were given the duty of taking native laws and customs into consideration and respecting the rights and interests of the native population when framing laws relating to the holding and transfer of land. In the section on land tenure I study how this clause was interpreted. What was meant by native interests? Who would determine what the interests and rights of natives to their land were? Questions regarding the use of land reveal the conflict

${ }^{23}$ Martinez, The Slave Trade and the Origins of International Human Rights Law, 13. 
between local traditions and the idea of modernization and modern ownership that the mandates were supposed to forward. The mandatories were seen as the guarantors of native rights and the possible threat to land rights was expected to come from within, namely from the ignorance of the natives. Thus, it was the mandatory's duty to teach proper ownership to the natives.

Issues relating to women did not appear in Article 22, the individual mandates, nor even in the questionnaires. However, in the minutes of the PMC they appeared as separate topics, often initiated by Dannevig. Women's issues also came under discussion through petitions sent by organizations advocating women's rights. In the section on women's issues, I have looked at how questions such as dowries, female circumcision, child marriages, polygamy, prostitution, education and labour were discussed in the PMC. How did the PMC see their role in improving the position of women in the mandates? Did the Commission see women as a group, the rights of which would warrant separate action, or were women seen as a part of a greater culture, the traditions of which were either to be respected or abolished as barbarous?

$* * * * *$

The themes chosen for this chapter, apart from women's issues, were present in the questionnaires that the PMC drafted for the mandatories of the $\mathrm{B}$ and $\mathrm{C}$ mandates during its first meeting. The aim of these questionnaires was to serve as frameworks for the reports that the mandatories were to draft. Thus, the purpose of the questionnaires was to provide the PMC with sufficiently detailed reports. New questionnaires to replace the old ones were drafted in 1926.

Rappard drafted the first preliminary draft questionnaire. In his draft he included the "special clauses with regard to the guarantees laid down by the Covenant or by the draft mandates" and "General clauses in accordance with the spirit of the Covenant". ${ }^{24}$ The topics included slavery, labour, arms and munitions, liquor, freedom of conscience, military clauses, economic equality, education, public health, land tenure, moral, social and material welfare of the natives (which included interests, rights and customs of the natives), public finance and demographic statistics. The questionnaire did not include a separate paragraph on women, but women's issues were dealt with under the other rubrics, especially labour and social and material welfare of the natives. The drafting of the questions regarding the mandates required some assistance from the representative of the ILO, whereas the other questions were drafted by the PMC alone.

I will present the formulation of the questionnaire of forced labour as an example. D'Andrade believed that the suggested formulation was too restrictive. As he would explain on many occasions, he believed that "forced" and "compulsory labour" were not synonymous. In his view, compulsory labour was

${ }^{24}$ Minutes 1 (1921), 25. 
necessary to prevent native idleness and laziness, which differed from "going to the native villages, to take natives and to bring them, under escort, to the locality where they were to work". ${ }^{25}$ The former simply meant that "the native should not be entitled to refuse to work, though he should have the right to choose freely the nature and place of his work". ${ }^{26}$ Rappard reminded D'Andrade that in studying the reports the PMC was bound by the provisions of the draft mandates, which included an absolute prohibition on forced labour. Thomas of the ILO noted that what needed to be taken into account in the questionnaire were both the prohibition of forced labour as stated in the mandatory agreements, and the actual conditions of the mandates. Thus, in the end, the questions on forced labour took the following form:

\section{Forced labour}

A. 1. What are the measures intended to ensure the prohibition of forced labour?

2. For what public works and services is forced native labour required? How is this regulated?

3. Are there any other forms of forced labour, such as labour in lieu of taxation, maintenance of highways, etc., except for essential public works and services?

4. Are there any other forms of forced labour, such as work on plantations or commercial undertakings? If so, how are these regulated?

5. What are the positive results of these measures?

B. 1. What measures have been taken with regard to the recruiting of labour?

2. Does the administration participate in this recruiting?

3. What compulsory measures are authorized with respect to native labour?

4. What powers has the Administration for dealing with labour contracts and preventing abuses in this respect?

\section{Free labour}

A. 1. What measures have been adopted to ensure that account is taken of the conventions or recommendations of the International Labour Conferences?

2. Are these Conventions or recommendations being carried into effect?

3. By what other provisions is free labour protected? 27

The other questions followed this same format, although with varying degrees of detail. In 1926 the PMC drafted a new set of questions, as it had become apparent

\footnotetext{
${ }^{25}$ Minutes 1 (1921), 31.

26 Ibid.

${ }^{27}$ Minutes 1 (1921), 32.
} 
that the original ones left out important questions. Thus, the new formulation took into account the already existing reports and the questions were drafted according to the actual reports of the mandatories. ${ }^{28}$

Not all of the issues dealt with by the questionnaires have been studied here. Drawing the line between "rights" issues and social questions is not easy, as many of the questions at hand, particularly slavery, forced labour, land tenure and the position of women, can be seen equally well as social questions than as rights. Moreover, the PMC has often discussed these questions as social issues, taking the perspective of the entire community instead of the individual. In cases where there has been a tension between the advantage of the community and that of the individual, the imagined good of the society has prevailed. The position of slaves serves as an example. In many of the PMC's discussions on slavery it became clear that it was often considered more important to maintain order in society by avoiding sudden changes than rapidly changing the position of individual slaves. Change and improvement was looked at from the perspective of generations. As the mandatories and the PMC were not actively advancing the independence of the mandates, they believed they had ample time to enable a change that would take place over generations.

Of course, by discussing matters that were seen as social questions rather than as rights, the problem of anachronism remains..$^{29}$ In reading the minutes of the PMC, I have been interested in examining how the different members of the PMC have discussed these questions and what point of view they have taken. The minutes do not show that the PMC would have viewed the issues as rights, not to mention individual rights or human rights. However, at times, they do reveal a certain sensibility towards the idea that the presence of a mandatory ought to lead to improvements in the conditions of individual slaves, labourers, and women and children as well.

\subsection{Freedom of Religion}

The provisions established in the mandates system set out to guarantee freedom of religion conceptualized as freedom of conscience. The aim of this section is to explore the freedom of religion in the mandates system, as discussed in the PMC. Freedom of religion was established as a freedom which was secured through the establishment of safeguards. Within the provisions, freedom of religion was understood to be universal which covered all religions. Within the League, freedom of religion was a contested issue and the practical application of the universal doctrine proved to be an issue, especially when the religion in question was not Christianity and even more so when discussing so-called native religions.

${ }^{28}$ Wright, Mandates under the League of Nations, 161.

${ }_{29}$ See Moyn, 'Substance, Scale, and Salience: The Recent Historiography of Human Rights'; Pedersen, 'Did "Imperial Trusteeship" have Anything to Do with "Human Rights"?' I have discussed the question of anachronism in the introduction to this study. 
In the following I will observe how the PMC pondered religious rights in Africa and the respective encroachments of Christianity and Islam. Freedom of religion was also a fundamental issue which separated discussions between $\mathrm{A}, \mathrm{B}$ and $\mathrm{C}$ mandates, mostly because the issue of freedom of religious rights was a highly contentious political issue of the mandated territories of Palestine and Syria. The concept of freedom of religion dates back several centuries and the concept had become generally accepted by the early $20^{\text {th }}$ century. However, the purpose and meaning of the concept has changed throughout its history. The flexibility of the concept of freedom of religion has a tendency to make it a good indicator of the influence of contemporary values, convictions and ideas.

Until the early $20^{\text {th }}$ century freedom of religion was closely tied to protection of (Christian) minorities. ${ }^{30}$ Europeans were worried about Christian minorities in new states and therefore freedom of religion was closely tied to minority rights and the standard of civilization. The Berlin Treaty of 1878 organized the postOttoman order in the Balkans and Eastern Europe and provided for freedom of religion in the newly-established states. Freedom of religion had become a condition for independence in the new states, as it would be during the League period as well (at least in most cases). ${ }^{31}$

Malcolm Evans regards religious freedom to be "one of the driving impulses behind the [League of Nations] minority treaties". ${ }^{32}$ According to him, they had an even more permanent meaning, as the principles that they expressed continued to live on in the European Convention of Human Rights. ${ }^{33}$ Evans, however, omits mandates from the scope of religious rights: "Just as religious freedom had previously been bound up with minority rights, since the 1940s the international protection of religious freedom has been bound up with the development of the concept of individual human rights as an object of international legal concern." 34 Yet, religious rights are granted explicitly in the mandates as well, and not only in connection with minorities.

Woodrow Wilson had planned that freedom of religion would have a stronger emphasis in the League Covenant. The plan to include religious freedom in the covenant was, however, silently buried, as it would have left the door open to

\footnotetext{
${ }^{30}$ On the duty of civilized nations to protect freedom of religion in less civilized states and to eliminate uncivilized practices, see Donelly, 'Human Rights: A New Standard of Civilization?', 5 .

${ }^{31}$ Evans, Freedom of Religion under the European Convention on Human Rights, 72.

32 Evans, Religious Liberty and International Law in Europe, 162.

33 Ibid., 171. Yet, the European Convention on Human Rights does not include specific provision on minorities. The International Covenant on Civil and Political Rights includes one article (Art. 27) on minority rights: "In those States in which ethnic, religious or linguistic minorities exist, persons belonging to such minorities shall not be denied the right, in community with the other members of their group, to enjoy their own culture, to profess and practise their own religion, or to use their own language."

34 Ibid., 173.
} 
Japan's initiative on the equality of races. ${ }^{35}$ Anna Su claims that the reason why freedom of conscience was attached to the mandates (and minority regimes) was President Wilson's insistence on including it in one way or another in the League Covenant. Wilson's preference would have been to include a general article of freedom of conscience in the Covenant, as he, according to $\mathrm{Su}$, believed that it would be needed to avoid future wars. Wilson believed religious intolerance to be a potential source of war. ${ }^{36}$ However, including the said article would have opened up discussion on Japan's proposal for racial equality. Thus, as Japan's proposal could not be approved, so Wilson's suggestion had to go. ${ }^{37}$ In a later version of his drafts for the mandates system he therefore included freedom of conscience and religion. ${ }^{38}$

By the time of the establishment of the League there was a will to grant freedom of religion not only to Christians but to other religions as well, at least in theory. However, in speech and in practice, many actors in the League (diplomats, PMC members, etc.) revealed that their way of thinking derived from the old prejudices and their wish to secure the rights of Christians. This is also apparent in the reactions to the Japanese equality initiative. However, the changes were already in the air, as can be seen from the comments to questions on the religious rights of some of the PMC members.

Freedom of conscience and the free exercise of all forms of worship were guaranteed both in B and C mandates. ${ }^{39}$ In the B mandates this was guaranteed by Article 22 of the League Nations Covenant, according to which administration must happen "under conditions which will guarantee freedom of conscience or religion, subject only to the maintenance of public order and morals ...". ${ }^{40}$ The C mandates had the same safeguards as the B mandates. ${ }^{41}$

The individual agreements of the B mandates declared that: "The Mandatory shall ensure in the territory complete freedom of conscience and the free exercise of all forms of worship which are consonant with public order and morality; missionaries who are nationals of states members of the League of Nations shall be free to enter the territory and to travel and reside therein, to acquire and possess property, to erect religious buildings and to open schools throughout the territory; it being understood, however, that the Mandatory shall have the right to exercise

\footnotetext{
${ }^{35}$ Petman, Human Rights and Violence: The Hope and Fear of the Liberal World, 98; Fink, 'The League of Nations and the Minorities Question', 2; Kawamura, 'Wilsonian Idealism and Japanese Claims at the Paris Peace Conference'; Lauren, 'Human Rights in History Diplomacy and Racial Equality at the Paris Peace Conference'.

${ }^{36} \mathrm{Su}$, 'Woodrow Wilson and the Origins of the International Law of Religious Freedom', 237-39.

${ }^{37}$ Ibid., 248-49.

38 Ibid., 254.

${ }^{39}$ League of Nations, The Mandates System: Origin, Principles, Application, 25.

40 Art. 22, part 5.

${ }^{41}$ Art. 22, part 6.
} 
such control as may be necessary for the maintenance of public order and good government, and to take all measures required for such control." 42

The statutes of the $\mathrm{C}$ mandates had a different wording, putting more emphasis on the limitations: "Subject to the provisions of any local law for the maintenance of public order and public morals, the Mandatory shall ensure in the territory freedom of conscience and the free exercise of all forms of worship, and shall allow all missionaries, nationals of any state member of the League of Nations, to enter into, travel and reside in the territory for the purpose of prosecuting their calling." 43 Thus, the provisions existed for the two different types of mandates, but the tools granted for limiting the right were stronger for the $\mathrm{C}$ mandates.

However, in practice the interpretation of freedom of conscience did not differ in the $\mathrm{B}$ and $\mathrm{C}$ mandates. Freedom of conscience granted by the different mandates was twofold. According to the mandates agreements, all forms of worship could be freely exercised, and thus, there was complete freedom of religion (limited, of course, by the condition of public order and morality). More important for the interests of the PMC and the discussions between the Commission was the second part of the clause, which provided for free entrance and residence of missionaries who were nationals of a League of Nations member state.

The statutes of the mandates ensured freedom of conscience that would cover the practice of native religions as well. However, as the paragraph limited the exercise of religion, conditioning it to public order and morality, it gave the PMC and especially the mandatories a very broad "margin of appreciation" in the interpretation of such rights. ${ }^{44}$ The PMC gave the mandatory a rather free hand as regards the limitations, with the reminder that such a condition (i.e. public order and morality) was necessary for the full development of all freedom. In the PMC's report of the third session it was written that: "[ $t]$ he Commission therefore drew attention to the fact that the mandate makes the free exercise of religion subject to the condition that it should not be prejudicial to public order, and that, in this connection, the mandate gives to the Mandatory the right to exercise such control as may be necessary for the maintenance of public order. ... and order is a necessary condition for the full development of all freedom, not excepting freedom of religion." The text originally related to B mandates, but Orts pointed out that it applied to the other mandates equally. ${ }^{45}$ Orts noted that the maintenance of order (if it was genuinely endangered) was the highest priority and free from criticism,

\footnotetext{
42 See e.g. British Mandate for Togoland, Art. 7.

${ }^{43}$ See e.g. Mandate for German South-West Africa, Art. 5.

${ }^{44} \mathrm{On}$ the concept of the margin of appreciation in religious rights, see e.g. Taylor, Freedom of Religion, 307-10.

${ }^{45}$ Minutes 23 (1933), 156.
} 
and would trump free exercise of religion, but only to the extent that it was necessary. 46

Of course, the task of making such limitations and creating a standard that would take all different interests into account, was not easy. While respecting native religions, the administration also had the duty to educate natives in moral matters, and the PMC at times struggled to reconcile these two duties. Palacios commented on the annual report of the Education Department of Tanganyika for 1930 about the "difficulty of achieving a code of pan-moral training to serve as a standard which would respect the convictions of such widely different persuasions as the Pagan, Mohammedan and Christian, and of the difficulties of creating a model type of African citizen". He believed that the people working for the administration and concerned with such matters "were doing so in the noblest spirit". ${ }^{47}$ Thus, he applauded the Department for their noble spirit faced with a difficult task.

Both the PMC and the mandatories felt an urge to convince others that they were taking the freedom of native religions seriously. The New Guinea administration ensured that it “... endeavoured, as far as was practicable and consistent with public morality and civilization, not to interfere with native customs and religious practices, or, for that matter, with the practice of the Christian religion".48 So, as the administration did not interfere with native customs, similarly it did not want to interfere with missions and their freedom. The representative of British Togoland also assured the PMC that it was the policy of the government to grant complete liberty of conscience and worship to all individuals, regardless of whether they were Christian, pagan or Muslim. He stressed that "it is not the duty of the Government ... to bring any pressure to bear on the people to abandon their pagan beliefs, provided of course that they do not involve the performance of any barbarous practices". ${ }^{49}$

However, even when the PMC reminded the mandatories about their duty to ensure that native religions were respected, it was quite apparent that they would have preferred the natives to be Christians. This preference was closely tied to demands of civilization. To the PMC, civilization equalled Christianity. Therefore, native religions were at best tolerated, but their practice was not encouraged. It was believed that civilization would bring about Christianity in its wake. Even though there was a freedom to practice all religions, and to some extent this was recognized by the PMC, the attitude of the Commission towards native religions was apparent. For example, on commenting on the evangelization of two native Sultans in Ruanda-Urundi, M. Palacios noted that "there was happily no such

\footnotetext{
${ }^{46}$ See Permanent Mandates Commission. Report on the Work of the Third Session of the Commission, submitted to the Council of the League of Nations on August 31st, 1923. 4 League of Nations Official Journal (1923), 1380.

${ }^{47}$ Minutes 22 (1932), 156.

48 Minutes 18 (1930), 72.

${ }^{49}$ Minutes 31 (1937), 88.
} 
clash between native traditions and civilized morality [in Ruanda-Urundi] as existed in other mandated countries in Africa". In his view the "conversion of the big chiefs ... must be recorded as a great innovation since they were the living embodiment of the ancient native customs." ${ }^{50}$

The fact that Christianity had been widely spread in the territories was generally applauded as simplifying the duties of the mandatory. Palacios questioned Samoa's representative about the true meaning of liberty of conscience in Samoa. To whom did it apply? Were "native beliefs unjustly interfered with under cover of the legislation concerning public order or morality"? ${ }^{51} \mathrm{Mr}$. Gray, representing Samoa's administration, assured him that "there was absolute liberty of conscience for everybody. All the natives were Christians". ${ }^{22}$ In certain regions of the French Cameroons, a report of the administration had noted that due to the presence of Catholic schools, a third of the children were baptized and another third were "sympathizers whose only reasons for not being converted were to be found in their attachment to certain traditions, especially polygamy". Even the remaining third could not be regarded "as beyond reach". ${ }^{53}$ To Dannevig's assumption that the missions of the said territory were working in the interest of the natives, Besson, the French representative, assured him that there was "not a shadow of doubt about that" ${ }^{54}$

It would be too simplistic to say that freedom of religion covered only Christianity in the $\mathrm{B}$ and $\mathrm{C}$ mandates, but native religions were hardly ever discussed unless they caused moral dismay, and there was a general understanding of the spread of Christianity benefiting the general progress of the territories.

Of course, Islam was an issue in some of the mandates, especially in the Cameroons. Muslims formed a part of the society that was considered to be at a more developed level and, at the same time, an existing reality that simply needed to be tolerated. Muslims were accepted as representatives of native customs, and for instance in the French Cameroons representatives of religious groups sat as assessors in helping solve disputes, their task being to "indicate the native custom". ${ }^{55}$ At the same time the PMC was appalled by certain customs it viewed as Muslim, including the slave trade. ${ }^{56}$

${ }^{50}$ Minutes 22 (1932), 249.

${ }^{51}$ Minutes 7 (1925), 24.

${ }^{52}$ Minutes 7 (1925), 24.

${ }^{53}$ Minutes 35 (1938), 126.

${ }^{54}$ Minutes 35 (1928), 127.

55 Minutes 15 (1929), 148.

${ }^{56}$ See e.g. Minutes 3 (1923), Comparative Statement concerning Matters Appertaining to Labour and Slavery in Territories under Mandate, Report by Mr. Grimshaw, representative of the International Labour Organization on the Mandates Commission, 263. 
In the discussions of the PMC the native religions represented tradition. It was the task of the mandatory system to preserve the worthiest traditions, to do away with the rest and to introduce progress. It was a difficult balancing act to establish the features of native religions that could be considered worth saving.

The emphasis of the discussions on religion between the PMC and the mandatories was how the different missions worked in the mandates rather than how freedom of native religions was arranged. The latter part of the article on freedom of religion in the mandates concerns the freedom of missions to enter and work in the territories.

The missions, representing various different churches and denominations (e.g. the Roman Catholic Church, the Church of England and other Protestant Churches), had a vast number of tasks to take care of and were an essential part of the administration. Apart from actual religious tasks, or tasks that could be considered to be practising religion, they founded different kinds of schools throughout the mandated areas and were largely responsible for health care, sending doctors, etc., ${ }^{57}$ and also had commercial enterprises, such as sawmills (that were partly used for educational purposes). ${ }^{58}$ The missions had been in the mandated territories longer than the mandatory administrations, many already during the German period, and therefore had experience of the territory that the administration had not yet accrued.

Many of the missions arranging education were government funded, and one of the tasks of the PMC was to ensure even distribution of resources between them. ${ }^{59}$ In some cases the mission schools had better resources and were applauded by the PMC for their accomplishments in education. ${ }^{60}$

Of course, when one looks at freedom of conscience from the point of view of the missions, an entirely different picture emerges. For the missions, freedom of conscience meant freedom from the supervision of the administration. In the event that they felt that the mandatories had too much control over the missions, the missions did not hesitate to invoke freedom of conscience for their own benefit. For example, the administration of New Guinea complained that "[E]ven a suggestion to the missions to submit reports might be misconstrued and held to infringe that all important principle of freedom of conscience". ${ }^{61}$ To a certain extent the PMC agreed with the missions. Palacios noted that the reports would be sent to the mandatory instead of the PMC: "This question had nothing to do with freedom of conscience but, on the contrary, would tend better to safeguard that freedom." 62

\footnotetext{
${ }^{57}$ Minutes 20 (1931), 25.

58 Minutes 18 (1930), 72.

${ }^{59}$ Minutes 15 (1929), 125.

${ }^{60}$ Minutes 16 (1929), 77.

${ }_{61}$ Minutes 20 (1931), 25.

62 Minutes 20 (1931), 25.
} 
The missionaries' double role as provider of religious services and as part of the administration by e.g. organizing education was not always easy, and could cause tensions between different interest groups. In South West Africa the administration tried to resolve the problem by requiring a permission from the missions to operate. However, this worried the PMC as they saw a risk of infringing freedom of worship if the missions could not operate freely. ${ }^{63}$

There was a certain amount of jealousy between the different missions, primarily about allocation of funding and other resources. There were, for instance, disputes on the allocation of funding between the Roman Catholic and the Finnish missions in South West Africa. ${ }^{64}$ The British representative of Tanganyika even went so far as to suggest spheres of influence to the various missions in Tanganyika, so as to avoid competition and friction between the missions. The PMC was reluctant to consent, recommending instead other ways to solve the tension. "The duty of the Commission was to safeguard the interests of the natives, and it was clear that the natives were not profiting by the rivalry of the missionaries," Lugard said. ${ }^{65}$ On the other hand, the PMC applauded a decree regulating various forms of worship in the Cameroons that had been made by the Catholic and Protestant missions together. ${ }^{66}$

Each of the A mandates provided for slightly different provisions regarding religious liberties. The British Mandate for Palestine stated that it being clearly understood that nothing should be done which might prejudice the civil and religious rights of existing non-Jewish communities in Palestine, or the rights and political status enjoyed by Jews in any other country..."(preamble); “The Mandatory shall be responsible ... for safeguarding the civil and religious rights of all the inhabitants of Palestine, irrespective of race and religion" (art. 2). Respect for their [the various peoples and communities] religious interests shall be fully guaranteed (Art. 9).67 "All responsibility in connection with the Holy Places and religious buildings or sites in Palestine, including that of preserving existing rights and of securing free access to the Holy Places, religious buildings and sites and the free exercise of worship, while ensuring the requirements of public order and decorum, is assumed by the Mandatory..." (Art. 13). ${ }^{68}$ Article 14 provided for a special commission to "study, define and determine the rights and claims in connection with the Holy Places and the rights and claims relating to the different religious communities in Palestine". "The Mandatory shall see that complete freedom of conscience and the free exercise of all forms of worship, subject only to the maintenance of public order and morals, are ensured to all. No discrimination

${ }^{63}$ Minutes 23 (1933), 92.

${ }^{64}$ Minutes 15 (1929), 72.

65 Minutes 3 (1923), 141.

66 Minutes 24 (1933), 44.

67 This was common with the Mandate for Syria and Lebanon, Art. 6.

68 On the rights of religious minorities as collective religious rights, see Dinstein, 'Collective Human Rights of Peoples and Minorities', 103. 
of any kind shall be made between the inhabitants of Palestine on the ground of race, religion or language." (Art. 15) ${ }^{69}$

Religion was a more discussed issue in the A mandates than in the $\mathrm{B}$ and $\mathrm{C}$ mandates. In Palestine, the plan of the administration was to arrange the three major religious communities, the Jews, the Christians and the Arabs (Muslims) in a pluralistic manner, where they could settle questions such as marriage, divorce, inheritance, etc. according to their own faiths. The problem, however, was that the division was not as clear as the administration would have wished it to be. The Jewish community was divided into several subgroups, including Zionists (the majority), Sephardic Jews and Ashkenazic Jews, the latter group including an even smaller extreme orthodox minority composed of Chassidim Jews. The Zionist organization was set to represent the Jewish population of the Mandate. ${ }^{70}$ The orthodox Ashkenazic communities petitioned to the PMC that their religious freedom was infringed by the administration's plan to neatly group the different religions according to the majority. One of the major issues was the ritual slaughter of animals. Ormsby-Gore, the British representative, assured that even when the Jewish people formed one large community (and if needed, the petitioners could form a sub-community), their religious rights would be taken care of. The PMC was not convinced and did not understand why the orthodox Jews could not form a separate community according to their own wishes. The British had understood that the Orthodox Jews would have wanted to expand their own religious customs to the entire Jewish community, being the "original Jews" in Palestine. To complicate matters even further, the Jews in Frankfurt, Germany, joined the Ashkenazi in their quest. The PMC pointed out that the administration was bound by Article 2 of the Palestinian mandate, which safeguarded the "civil and religious rights of all the inhabitants of Palestine, irrespective of race and religion". ${ }^{71}$

Syria had also suffered serious discontent and unrest, and the Executive Committee of the Syro-Palestinian Congress approached the League of Nations with an petition in 1925. According to this appeal, France had taken no measures to guarantee freedom of worship. Syria had a numerous amount of small religious communities, and these had been used as a basis for the political organization of the state. However, according to the appeal, only communities large enough were granted the possibility to stand for election. Thus, small communities had to join others in order to make a large enough entity. The appeal went on to say that: "The French have done everything in their power to stir up religious antagonism

69 This article existed with a slightly different wording in the Mandate for Syria and Lebanon: "The Mandatory shall ensure to all complete freedom of conscience and the free exercise of all forms of worship which are consonant with public order and morality. No discrimination of any kind shall be made between the inhabitants of Palestine on the ground of race, religion or language." Art. 8.

${ }^{70}$ See Art. 4 of the Mandate for Palestine.

${ }^{71}$ Minutes 7 (1925), 106-109. 
and to favour one community at the expense of another. ... This is how France, the home of liberty and the proclaimer of the rights of man, applies her noble precepts in Syria and the Lebanon."72

There was a constant danger of conflict between communities. In the A mandates the administration had the difficult task of balancing between different religious groups and their claims of ownership of holy places: "Feelings ran high $\ldots$ and there was a constant danger of incidents occurring between the officiating clergy." 73 In Syria the right to convert to another religion raised questions. From the point of view of freedom of conscience, should the administration respect the prohibition of conversion as applied by the Muslim religion, or the right to choose one's religion? Rappard explained that the mandate required religious tolerance and it was the administration's duty to grant it. According to him, claiming that respecting the prohibition of conversion as a religious practice was akin to accepting cannibalism because it was practised in a certain country. It was precisely the mandate's task to change such practices. The French representative accepted Rappard's idea in principle, but maintained that "it could only come about with a new generation". He did not want to risk converts being murdered. ${ }^{74}$

It was thought that in some cases Christians would expect the mandatory to grant them preferential treatment, as was the case in Lebanon, and this would cause suspicion among Muslims. ${ }^{75}$ There were often differing views between the mandatories and the locals over whether religious rights had been violated. Here, the PMC resolved the issue through strict interpretation: if the communities felt their rights were violated, they were. The PMC noted that if some groups were complaining about their religious rights, there apparently was a problem and such rights were not granted in an appropriate manner. This applied, for example, to the community of Ashkenazic Jews in Palestine that was striving for its own religious traditions to be accepted by the majority. Some members of the PMC wanted to wait and see if the communities would reach an agreement, but Rappard noted that the Commission could not disregard petitions. The Chairman was not satisfied with Britain's way of handling the matter and noted that: "He thought personally that the mandatory Power might have shown more prudence in dealing with such delicate questions." 76

At times religious rights would clash with other, especially women's, rights. In a petition by the Council of the Ashkenazic Jewish Community, it complained about the lack of religious freedom: "The Statute for the Organization of Jewish Communities in Palestine, proposed by the secular and national Jews ... deprives

72 Minutes 8 (1926), Annex 3, Executive Committee of the Syro-Palestinian Congress, Appeal addressed to the Sixth General Assembly of the League of Nations, Cairo September 29th, 1925, 180-181.

${ }^{73}$ Minutes 15 (1929), 95.

${ }^{74}$ Minutes 27 (1935), 88.

75 Minutes 8 (1926), 23.

${ }^{76}$ Minutes 7 (1925), 106-109. 
Jewish inhabitants of freedom of religion and conscience and endangers the possibility of observing religion in communal life in Palestine in the future. The said Statute already contains clauses that are against Jewish morals and religion, such as giving women active and passive right of election, which is not practised in any existing Jewish community." They referred to the customs of their community as the "tradition and ... life of the original Jewish settlement in Palestine". ${ }^{77}$

As with the League of Nations minorities regime, religion was to become an important condition for granting independence to new states. In the context of mandates, this meant scrutinizing Iraq's treatment of its minorities before giving the PMC's official recommendation for Iraq's independence. For the PMC, the major interest seemed to be on the Christian Armenian minority: "Recognition of universal freedom of conscience and freedom to practise the various forms of worship, as well as respect for missionary enterprise, religious and social, subject to the necessary measures for the maintenance of public order, morals and good government, cannot reasonably be deemed an infringement of a country's independence or sovereignty." This was a principle that the PMC feared Iraq would not consent to if it became independent. ${ }^{78}$ In freedom of religion the PMC recognized a kind of a higher principle of rights, above independence or sovereignty. ${ }^{79}$

The League of Nations through the Mandates Commission grappled with issues of freedom of religion in highly different ways in relation to different mandated areas. Within the African territories the questions that arose were mostly linked with zealous missionaries whose conception of religious freedom was myopic. For them, freedom of conscience was shorthand for their own freedom from interference by the mandates administration. With regard to the $\mathrm{B}$ and $\mathrm{C}$ mandates, the issues of religious freedom were little different to those faced by the contemporary colonial administrations. The situation was completely different with regard to the A mandates, especially Palestine and Syria, including Lebanon. There conflicts between population groups took the form of religious conflict. In places like Syria and Lebanon there was a deep mistrust that the Christian mandatory powers would give preferential treatment to the Christian population. In Palestine religious conflicts took place between the fast- growing Jewish population, the Muslim elite and the Christian minority. A further issue was the protection of holy sites. The concern shown by the PMC for Christians is evident when it discussed the protection of the Christian minorities in the event of Iraqi independence.

\footnotetext{
77 Minutes 7 (1925), Annex 8, Petition from the Council of the Ashkenazic Jewish Community at Jerusalem, 182.

${ }^{78}$ Annex 3. Admission of Iraq to the League of Nations. Considerations which might serve as a basis for the discussion of this question. Note by M. Van Rees, Minutes 18 (1930), 172.

${ }^{79}$ On other conditions for newly independent states, see section 4.2.
} 


\subsection{Slavery}

One of the most voluminous issues dealt with by the PMC revolved around personal freedom, or in the vocabulary of the time, slavery. In this section I will study how the idea of anti-slavery evolved from the early years of the abolitionist movement and came to influence the working of the League of Nations. Slavery can be seen as an issue of Empire, the commercial foundation of colonial empires being founded on slave labour. Equally, the abolitionist movement had its roots in imperialist thought as well. It gave a moral justification to the colonial project and opposition to slavery was intimately tied to the idea of the superiority of civilization. Abolitionism was initially a British initiative, and although international agreements condemning slavery may be traced back to the early $19^{\text {th }}$ century, most of these agreements may be traced to vocal popular opposition to slavery in Britain. For the League of Nations mandates system, the existence of slavery was clearly a moral and ethical issue, one that found wide support both in idealistic as well as realistic members. In the following we shall see how the factfinding operation of the PMC struggled with the practical implications of this idealistic demand. They grappled not only with definitional issues such as whether various kinds of dependencies should be defined as slavery, but also purely exploitative new practices, for example in South West Africa.

Britain started leading the anti-slavery movement from the early $19^{\text {th }}$ century onwards. The earliest activists were members of different churches, and by the end of the century the campaign against slavery was on the official British agenda as well. Britain acted as the police of the seas, searching and seizing vessels of other nations suspected of carrying slaves and setting up tribunals around the Atlantic to confiscate the ships and liberate the slaves onboard. Britain's actions were enabled by bilateral treaties, negotiations of which were achieved through both diplomatic means, and coercion and bribery. ${ }^{80}$

Several reasons have been given for Britain's eagerness to stand in the forefront of the abolition movement. The history of abolition is not necessarily a history of humanitarianism or benevolence, though these values did play a role as well, especially in the early campaign. One common purpose for the early abolitionists, and people demanding measures against slavery was the belief in their own superior civilization. First, Europeans tended to compare themselves with Americans, and particularly the British compared themselves to all the rest. ${ }^{81}$ Thus, a great influence has been colonial competition, economics, and Britain's fear of losing its status as the leading maritime power. ${ }^{82}$ The historian Suzanne Miers notes that opposition of the slave trade in Britain in the early $19^{\text {th }}$ century was based on economic competition. The reasons behind Britain's vision of itself

${ }^{80}$ See Martinez, The Slave Trade and the Origins of International Human Rights Law; Grant, 'The British Empire, International Government, and Human Rights', 574.

${ }^{81}$ Blackburn, The American Crucible: Slavery, Emancipation and Human Rigbts, 146.

82 Miers, 'Slavery and the Slave Trade as International Issues 1890-1939', 19. 
as the leading force in abolishing the slave trade lay in domestic politics. ${ }^{83}$ What helped to ease the path to abolitionism was the fact that Britain did not have too much to lose. The problems experienced by the French in their Caribbean colonies diminished competition from them. As far as competition between the British and the Americans was concerned, if one abolished slavery, then the other one would be forced to follow. Ending the slave trade would increase prices and therefore profits. Thus, both the British and the Americans could try to emphasize their moral superiority without too many economic risks. ${ }^{84}$ Abolishing slavery led to diminishing production and as a result the British established new categories of slavery, i.e. slaves without legal status. ${ }^{85}$ Also, employers in the colonies could now use the newly-freed work force for their own purposes. ${ }^{86}$ Lauren Benton and Aaron Slater argue that the discussion on the rights of slaves in the British Empire served the purpose of strengthening the Empire as opposed to the slave owners in the British colonies. As the Empire presented itself as the giver of rights, it would prevent the periphery from taking over that task. ${ }^{87}$

Britain's abolitionist campaign was started by activists, mainly belonging to different churches, who started to put pressure on the government. The campaign expanded due to the active role of both churches and newspapers. ${ }^{88}$ The abolitionist movement's success was due to several reasons, including their successful marketing campaign, a fear of slave revolts, which meant some planters opted for emancipation (though expecting compensation), and also diminishing profits from the slave colonies. ${ }^{89}$ It was also anticipated that freed slaves would work harder when paid for their work. ${ }^{90}$ For a long time, the French and the Americans, not to mention the smaller actors in the slave trade, showed little interest in an active campaign against slave trade. ${ }^{91}$ The internationalization of the abolitionist campaign, however, can be linked to the British anti-slavery movement.

Historically, restricting slavery has been a way for colonial powers to flaunt their benevolence and humanitarianism. ${ }^{92}$ However, even when abolition was progressing, and Britain began to use its maritime power to influence the slave trade in other nations as well, a constant conflict between benevolence and

\footnotetext{
83 Ibid., 16.

${ }^{84}$ Blackburn, The American Crucible: Slavery, Emancipation and Human Rights, 228-29.

${ }^{85}$ Miers, Slavery in the Twentieth Century, 20.

${ }^{86}$ Miers, 'Slavery and the Slave Trade as International Issues 1890-1939', 21.

87 Benton and Slater, 'Constituting the Imperial Community: Rights, Common Good, and Authority in Britain's Atlantic Empire, 1607-1815.'

${ }_{88}$ Miers, Slavery in the Twentieth Century, 2.

89 Ibid., 5.

90 Ibid., 6.

91 Drescher, 'From Consensus to Consensus: Slavery in International Law', 91; Miers, Slavery in the Twentieth Century, 21.

${ }^{92}$ Lauren, The Evolution of International Human Rights: Visions Seen, 40.
} 
economics remained. This conflict would continue well into the $20^{\text {th }}$ century and would influence the discussions on slavery in the Permanent Mandates Commission. ${ }^{93}$

Britain aimed at internationalizing the campaign against the slave trade by legal means. Early efforts include the Congress of Vienna in 1814, where slave traffic was condemned as "repugnant to the principles of humanity and universal morality" but not considered illegal, ${ }^{94}$ and the bilateral treaties allowing mutual search of ships and creating bilateral courts and mixed commissions to condemn slave traders. ${ }^{95}$

Slavery and the slave trade were only briefly on the agenda at the Berlin Africa Conference of 1884-1885. The final act of the conference stated that the slave trade was "forbidden by international law", but no enforcement machinery was provided. ${ }^{96}$ Countries where the slave trade was still practised could be left outside the sphere of international law. ${ }^{97}$ According to Article 6.1: "All the Powers exercising sovereign rights or influence in the aforesaid territories bind themselves to watch over the preservation of the native tribes, and to care for the improvement of the conditions of their moral and material well-being, and to help in suppressing slavery, and especially the slave trade. They shall, without distinction of creed or nation, protect and favour all religious, scientific or charitable institutions and undertakings created and organized for the above ends, or which aim at instructing the natives and bringing home to them the blessings of civilization." Thus, the treaty gave the colonial powers the "noble" task of putting an end to slavery by civilizing them, ${ }^{98}$ a task that would later be institutionalized by the mandates system.

The Brussels Act of 1890 was the first multilateral treaty against the slave trade. According to Britain, colonies were needed to improve the position of the natives, including slaves. It was also believed that the gradual civilization of the colonies would by itself take care of the problem of slaves. ${ }^{99}$ The treaty stressed the role of imperialism in the international campaign against slavery. 100 The act was the first supervisory machinery, though it did not provide means for enforcement. It did, however, grant the possibility to search for slaves from the ships of other nations and thus control maritime traffic. ${ }^{101}$

\footnotetext{
${ }^{93}$ Miers, Slavery in the Twentietb Century, 4.

${ }^{94}$ Drescher, 'From Consensus to Consensus: Slavery in International Law', 91.

${ }^{95}$ Ibid., 92 and 93; Miers, Slavery in the Twentieth Century; Martinez, The Slave Trade and the Origins of International Human Rights Law.

${ }^{96}$ Drescher, 'From Consensus to Consensus: Slavery in International Law', 97.

${ }^{97}$ Ibid.

${ }^{98}$ See Blackburn, The American Crucible: Slavery, Emancipation and Human Rights, 457.

${ }_{99}$ Miers, 'Slavery and the Slave Trade as International Issues 1890-1939', 21.

${ }^{100}$ Drescher, 'From Consensus to Consensus: Slavery in International Law', 98.

${ }^{101}$ Miers, 'Slavery and the Slave Trade as International Issues 1890-1939', 19.
} 
From 1919 onwards there was official slave trade only to the Arab countries and the Persian Gulf. The Brussels Act had lapsed during the war and the colonial powers were not interested in renewing it. Instead, a small clause was added to a treaty signed in St. Germain-en-Laye in 1919 on "the complete suppression of slavery in all its forms". ${ }^{102}$ In addition, Article 23 of the Covenant of the League of Nations provided for "fair and humane conditions of labour for men, women and children", although it was not clear if this applied to the colonies as well, since there was a separate clause for "just treatment of the native inhabitants of territories under their control". ${ }^{103}$ The slave trade, not slavery itself, was prohibited by the mandates Article 22 of the League of Nations Covenant. The individual B mandates included the suppression of "all forms of slave trade" and "the eventual emancipation of all slaves", 104 whereas the C mandates included only the former. ${ }^{105}$ Thus, the $\mathrm{B}$ mandates went further than the Covenant in providing for the abolition of slavery as well. ${ }^{106}$ In the A mandates slave trade was approached as a treaty obligation. According to the mandates agreements, the duty of the mandatory was to adhere on behalf of the mandate to international conventions on slave trade. ${ }^{107}$

The Slavery Convention of 1926 was created under the auspices of the League of Nations. This treaty condemned slavery "in all its forms". ${ }^{108}$ Slavery was defined as "the status or condition of a person over whom any or all of the powers attaching to the rights of ownership are exercised". ${ }^{109}$ This did not necessarily include "lesser forms of exploitation", such as serfdom or debt bondage, since a distinction between slavery and such "lesser forms" was formed by the League of Nations Committee of Experts on Slavery in 1936.110 This treaty was also a tool for Europeans to eradicate the last remnants of slavery outside the sphere of civilization and to overcome "the hurdles of native ignorance, laziness and cultural

\footnotetext{
102 Ibid., 22.

103 The Covenant of the League of Nations (1919), Article 23.

104 See e.g. the Mandate of British Cameroons, Article 4.

105 See e.g. the Mandate of Nauru, Article 3.

106 See Minutes 1 (1921), 25.

107 French Mandate for Syria and Lebanon, Art. 12; British Mandate for Palestine, Art. 19.
}

108 Drescher, 'From Consensus to Consensus: Slavery in International Law', 99; Miers, 'Slavery and the Slave Trade as International Issues 1890-1939', 28.

109 Slavery Convention (1926), Article 1(1). See also Allain, 'The Legal Definition of Slavery into the Twenty-First Century', 199.

110 Ibid., 203. However, a wider definition of slavery was also considered mainly for the purpose of investigating the existence of slavery in Liberia. An International Commission of Inquiry into the Existence of Slavery and Forced Labour in the Republic of Liberia was set up as it was not clear whether slavery existed there as defined by the 1926 convention. Lesser servitudes, however, did exist, thus the commission expanded its mandate to include both "common slavery" and "oppressive practices restrictive of the freedom of persons, constituting conditions analogous to slavery”. Ibid., 204-205. 
backwardness". 111 International law now included a formal prohibition of slavery and the Convention on the prohibition of slavery was also applied to the mandates. ${ }^{112}$

Especially in the early years of the mandates, very little was known about slavery in the territories. There were problems relating to the definition of slavery, where the mandatories were not too willing to admit the existence of slavery and would rather speak of it in different terms. Or, on other occasions, they would admit the existence but note its illegality. ${ }^{113}$ Of the $\mathrm{C}$ mandates, South West Africa had already been declared slavery free at the second session, but later it was noticed that the matter was more complicated than the administrator had been willing to admit. ${ }^{114}$

The Permanent Mandates Commission prepared a questionnaire with which it wanted to find out about slavery in the mandated territories. In the resulting report in 1923, it was noted that in practice slavery existed in many of the mandates, including, but not limited to, Tanganyika, Ruanda-Urundi, both the British and French Cameroons and French Togoland. ${ }^{115}$ Thus slavery was particularly a problem in the B mandated territories which was in some territories explained by the influence of Islam. ${ }^{116}$ In many of the territories it was nevertheless not clear whether slavery was legally permitted. For instance, in French Togoland, preconditions for freeing slaves did exist; in Ruanda-Urundi there was an order to register domestic slaves, whereas in Tanganyika an ordinance came into force which prohibited keeping anyone a slave against his will. Also in South West Africa slavery was described as having a "mild character", which required no "drastic action". These slaves were said to "voluntarily pledge the persons of themselves and their children as security for

${ }^{111}$ Drescher, 'From Consensus to Consensus: Slavery in International Law', 99.

112 Slavery Convention (1926).

113 See Comparative Statement concerning Matters Appertaining to Labour and Slavery in Territories under Mandate, Report by Mr. Grimshaw, Minutes 3 (1923), Annex 5, 263. Harold Grimshaw, was the representative of the International Labour Organization on the Mandates Commission and was also a member of the League of Nations Temporary Slavery Commission of 1924-25. See Miers, 'Slavery and the Slave Trade as International Issues 1890-1939', 26.

114 Comparative Statement concerning Matters Appertaining to Labour and Slavery in Territories under Mandate, Report by Mr. Grimshaw, Minutes 3 (1923), Annex 5, Appendix I - Slavery, 263.

115 Comparative Statement concerning Matters Appertaining to Labour and Slavery in Territories under Mandate, Report by Mr. Grimshaw, Minutes 3 (1923), Annex 5, Appendix I - Slavery, 273-275. See e.g. Goodridge, 'The Issue of Slavery in the Establishment of British Rule in Northern Cameroun to 1927'.

116 Comparative Statement concerning Matters Appertaining to Labour and Slavery in Territories under Mandate, Report by Mr. Grimshaw, Minutes 3 (1923), 263. 
some debt or obligation" for a period lasting only as long as the obligation. ${ }^{117}$ Thus, legally slavery was not allowed but did exist in practice. ${ }^{118}$ The existence of slavery was not only limited to the $\mathrm{B}$ and $\mathrm{C}$ mandates, but in Jordan the administration also reported that "semi-slaves", descendants of African pilgrims to Mecca and captured by Arabs, did exist. ${ }^{119}$ The same applied to Syria and Lebanon. Also in this case the administration was eager to differentiate the slave trade by local tribes and domestic slavery (or a "domestic status which was not without some resemblance to slavery"), practised by the Muslim population. "If ... it was a question of interfering in the domestic life of the Moslems, it would be necessary to proceed with extreme prudence." 120

The attempt to "round-up" Bushmen by farmers in South West Africa illustrates the difficulties in gaining reliable information on slavery in the mandates. The Windhoek Advertiser had written of two incidents where native Bushmen had been rounded up and sold to farmers as servants. The Advertiser aimed at the information reaching the League of Nations, as they wished the administration to be open about such incidents rather than "some person should creep away to Geneva and prompt the members of the Mandates Commission to ask questions which might serve to indicate that an attempt was being made in this country to hush up what may be a most disreputable business. We are aware that the League of Nations are constantly on the watch for anything that savours of slavery or forced labour." 121 When questioned about the incidents by the PMC, South Africa responded that one of the incidents was a pure misunderstanding. The Bushmen had simply deserted from the service of the farmers and were persuaded to return to their duties. The second incident, however, could not be justified, and "a very serious view of their conduct had been taken by the Administration”. ${ }^{122}$ The perpetrators were arrested and sentenced a fine of $£ 5$. The lenient punishment was explained by the fact that the "action had been due mainly to youthful exuberance". 123 Moreover, "some of the Bushmen were very troublesome people", although, of course, this could not be used as a justification. ${ }^{124}$ The South African representative, Mr. Clarke, emphasized that "slavery was unknown in the territory, though there were occasional cases in the

\footnotetext{
117 Memorandum on Slavery and Labour Questions based on Reports of the Mandatory Powers for the years 1923 by Mr. Grimshaw, Representative of the International Labour Office, Minutes 4 (1924), Annex 3, 172.

118 Comparative Statement concerning Matters Appertaining to Labour and Slavery in Territories under Mandate, Report by Mr. Grimshaw, Minutes 3 (1923), 263.

119 Minutes 7 (1925), 117.

${ }^{120}$ Minutes 7 (1925), 30.

121 Minutes 18 (1930), 191.

122 Minutes 18 (1930), 140.

${ }_{123}$ Minutes 18 (1930), 140.

${ }^{124}$ Minutes 18 (1930), 140.
} 
north-eastern region". ${ }^{125}$ While the PMC questioned the leniency of the sentence, ${ }^{126}$ it was nevertheless concluded that the first incident did not seem to be serious and the second, "regrettable though it is", was taken care of by the courts in South West Africa. ${ }^{127}$

Of the different kinds of slavery, domestic slavery was at the time of the establishment of the mandates still prevalent in many of the mandated territories, e.g. Tanganyika, Togoland and the Cameroons. ${ }^{128}$ In French Togoland domestic slaves would recover their freedom if they fulfilled the conditions set by the administration: paying their taxes, fulfilling their regular labour dues and complying with other obligations imposed on natives. It remains unclear what would happen if they refused to fulfil these conditions. Would they be forced to retain their status as slaves? ${ }^{129}$ In their next report the administration maintained that it was not "necessary or convenient to adopt further direct measures against what remains of this system". ${ }^{130}$

Lord Lugard, like many of his contemporaries, understood domestic slavery to a certain extent. Lugard maintained that the "temporary continuance" of domestic slavery had some advantages "as a form of labour-contract between a more advanced and a very primitive people" in cases where currency did not yet exist and the native was not aware that he could sell his services against such a currency. ${ }^{131}$

In some cases slavery was more comparable to adoption, which made it more acceptable or even desirable. "[C]hildren were sometimes entrusted to large traders, who became responsible for their instruction. This system, however, amounted to a kind of provisional adoption in the broadest sense of the word, the results of which were most satisfactory, for the children adopted in this way could get better instruction than would be possible in their own village." ${ }^{132}$

The attitude towards slavery was above all practical. When the Permanent Mandates Commission discussed the reports of the mandatories and asked them about slavery, they stated that there was either no slavery or that there was at least an intention to diminish or abolish it. For example, in Tanganyika it was stressed that the abolition of slavery should not happen too quickly, as it was

125 Minutes 18 (1930), 140.

126 Minutes 18 (1930), 140

${ }^{127}$ Minutes 18 (1930), 192.

128 Comparative Statement concerning Matters Appertaining to Labour and Slavery in Territories under Mandate, Report by Mr. Grimshaw, Minutes 3 (1923), 273; Minutes 7 (1925), 43.

${ }^{129}$ Comparative Statement concerning Matters Appertaining to Labour and Slavery in Territories under Mandate, Report by Mr. Grimshaw, Minutes 3 (1923), 275.

${ }_{130}$ Memorandum on Slavery and Labour Questions based on Reports of the Mandatory Powers for the years 1923 by Mr. Grimshaw, Representative of the International Labour Office, Minutes 4 (1924), Annex 3, 171.

${ }^{131}$ Lugard, The Dual Mandate in British Tropical Africa, 365.

132 Bonnecarrère, on French Togoland, Minutes 6 (1925), 27. 
expensive because the slave owners should be remunerated for losing their property, i.e. the slaves, and there were no funds for such purposes, ${ }^{133}$ or that the emancipation of slaves would happen too quickly, which could bring about social problems. Also, so- called "benevolent forms of slavery" were mentioned, in this connection meaning domestic slavery. ${ }^{134}$

Like other unaccepted customs, slavery was externalized as a native vice, from which civilization would gradually save the mandates. There was no rush, as slavery had always existed and exposure to Western civilization would gradually abolish it. ${ }^{135}$ Also, general economic development would do away with slavery. ${ }^{136}$ The changes brought about by the abolition of domestic slavery were also feared and it was anticipated that because of poor living conditions, there was little demand for emancipation. ${ }^{137}$ According to the British representative, Mr. OrmsbyGore, the administration in Tanganyika had been "too precipitate in abolishing slavery". The emancipation had resulted in the "ruin of the plantations and in the starvation of the emancipated slaves". ${ }^{138}$ Another concern were the compensations that would have have to be paid to slave owners. ${ }^{139}$ Compensation to former slaves was never discussed. Lugard recognized slavery as both a moral issue and an administrative problem: ${ }^{140}$ "Sudden emancipation would dislocate the whole social fabric." 141 The social problems that would occur in such an instance would include men thrown into the streets, women becoming prostitutes and masters, plantations and the industry in ruin. ${ }^{142}$ Moreover, "Africans of the lower classes ... love to attach themselves to a 'big man'”. ${ }^{143}$ Lugard's solution to these problems was to abolish slavery as a legal status. Thus the emancipation would happen gradually (even over a period of generations) and both the slaves and the masters would have enough time to accustom themselves to the new situation. ${ }^{144}$ This applied,

133 Minutes 1 (1923), 21. See also Lugard, The Dual Mandate in British Tropical Africa, 367.

134 Minutes 3 (1923), 23.

135 Memorandum on Slavery and Labour Questions based on Reports of the Mandatory Powers for the years 1923 by Mr. Grimshaw, Representative of the International Labour Office, Minutes 4 (1924), Annex 3, 171. Also the Germans, during the time they governed in the mandates, believed that slavery would disappear by itself. See eg. Eckert, 'Slavery in Colonial Cameroon, 1880s to 1930s'; Donelly, 'Human Rights: A New Standard of Civilization?', 10.

136 Comparative Statement concerning Matters Appertaining to Labour and Slavery in Territories under Mandate, Report by Mr. Grimshaw, Minutes 3 (1923), 265.

137 Comparative Statement concerning Matters Appertaining to Labour and Slavery in Territories under Mandate, Report by Mr. Grimshaw, Minutes 3 (1923), 265.

138 Minutes 6 (1925), 129.

139 Minutes 1 (1921), 21.

140 Lugard, The Dual Mandate in British Tropical Africa, 362.

141 Ibid., 367.

142 Ibid.

143 Ibid., 373-374.

144 Ibid., 368. 
however, only to Muslim countries. Elsewhere, in his view, slavery should be abolished entirely. ${ }^{145}$ In Lugard's view, the most difficult task in putting an end to slavery was "to eradicate the servile habit of mind, bred by long traditions of slavery, to inculcate the right to be free, and to educate the native to a sense of personal responsibility, initiative, and aspiration, in order that he may learn the dignity of free labour and appreciate his duty as a citizen and to posterity". ${ }^{146}$ This could be achieved by example, which in Lugard's view the British administration amply provided. ${ }^{147}$

Grimshaw, the ILO representative, recommended the abolition of the legal recognition of slavery and the emancipation of slaves: "Any recognition of the legal status of slavery appears to accord ill with the terms of the mandates." 148 It would appear that the administrators understated the suffering caused by slavery, stating in their reports that domestic servitude did not necessarily mean more suffering than freedom with little economic means would mean or that there was no desire for emancipation among the natives.

The dialogue on slavery had three parties: the weak natives, still in darkness, at the mercy of stronger forces (or, alternatively, the natives who still held slaves); the administration, who did not permit slavery but would gradually abolish it bringing the light of civilization (maybe after some generations); and the Mandates Commission, which through its questionnaires tried to make sense of the situation of slavery in the mandates. Gradually it emerged to the mandatory states that the Permanent Mandates Commission truly held slavery to be a problem and was serious about abolishing it. The Mandates Commission brought to light practices of the administration in the mandates, and thus the mandatories had to reveal the situation concerning slavery and labour conditions in the mandated territories. There was much that was not known, but at least the mandate administrations were forced to explain how they planned to improve the situation of their inhabitants. ${ }^{149}$

Forced labour (to which I will return in the next section) was hardly a better option than slavery. Slavery transferred into forced labour in several ways. The employers needed to fill the work force gap created by abolition, and therefore slave traders started to convey employees into forced labour. The justification was to be found in laws prohibiting vagrancy. 150

The abolition of slavery has been a tool for Western powers to judge the level of civilization in other countries. Slavery has been used as a reason for Western powers to establish colonies, as the colonizers felt that their superior level of

145 Ibid., 369.

146 Ibid., 388.

${ }^{147}$ Lugard, The Dual Mandate in British Tropical Africa, 388.

148 Comparative Statement concerning Matters Appertaining to Labour and Slavery in Territories under Mandate, Report by Mr. Grimshaw, Minutes 3 (1923), 264.

${ }^{149}$ Miers, Slavery in the Twentieth Century, 60.

${ }^{150}$ Blackburn, The American Crucible: Slavery, Emancipation and Human Rights, 459. 
civilization and the example they set was needed to abolish slavery. These feelings of superiority were intertwined with genuine benevolent feelings toward the natives. As Lugard pointed out: "To the slave the effect [of slavery] is hardly less demoralizing. $\mathrm{He}$ is deprived of the dignity of manhood." 151 The professionalization of international law in the 1860s and 1870s led to the definition of the limits of the field. ${ }^{152}$ Slavery was used as a means to determine states as civilized or uncivilized. Thus anti-slavery became a sign of civilization. ${ }^{153}$ Due to the evolution of ideas concerning slavery, there had naturally been a shift from the idea of slavery being civilized to slavery being barbarous. During the mandates period, anti-slavery continued to act as a way of emphasizing civilization and the necessity of administration. Superior civilization was a means to differentiate the mandatories from the natives.

Italy's conquest of Abyssinia was justified on the grounds of fighting slavery and bringing civilization. ${ }^{154}$ The abolition of slavery shows how the concept of civilization was used by the West to change the international order. ${ }^{155}$ Apart from using it as a motivation for colonizing, the concept of civilization was used as a means to include or exclude other countries from the international community. The independence of Abyssinia serves as an example. Britain was opposed to the independence of Abyssinia because slavery still existed in the country. On the other hand, Italy used this lack of civilization as a pretext for its conquest. ${ }^{156}$

The definition of slavery and the treaty against slavery were to be applied only to the "other" and the target of the definition was above all Ethiopia. ${ }^{157}$ Abolition of the slave trade had much to do with racial hierarchies, civilization, and the moral superiority of a paternalistic liberator, granting rights and acting as a good-doer and educator.

The prohibition of the slave trade is often mentioned as the first human right or one of the first human rights. ${ }^{158}$ Jenny Martinez in her recent book The Slave Trade and the Origins of International Human Rights Law has claimed that international human rights law has its origins in the abolitionist movement of early $19^{\text {th }}$ century Britain. Moreover, she maintains that the mixed slavery courts were the first human rights courts. The courts were established in 1817 at Britain's initiative to

${ }^{151}$ Lugard, The Dual Mandate in British Tropical Africa, 355.

152 Koskenniemi, The Gentle Civilizer of Nations.

${ }^{153}$ Drescher, 'From Consensus to Consensus: Slavery in International Law', 95.

${ }^{154}$ See e.g. Allain, 'Slavery and the League of Nations: Ethiopia as a Civilised Nation'.

155 Ibid., 214.

156 Ibid., 206.

${ }^{157}$ Allain, 'The Legal Definition of Slavery into the Twenty-First Century', 199.

158 Ishay, The History of Human Rights from Ancient Times to the Globalization Era, 155; Redman, 'The League of Nations and the Right to Be Free from Enslavement: The First Human Right to Be Recognized as Customary International Law'; Martinez, The Slave Trade and the Origins of International Human Rights Law; Miers, Slavery in the Twentieth Century, 4. 
try slave traders and redistribute their assets. Before the establishment of the Courts, during the Napoleonic Wars, Britain had been unilaterally catching and searching vessels that she believed were transporting slaves. After the Wars, Britain was forced to find a new justification for searching such vessels, for searching enemy ships no longer applied. By bribing weaker maritime powers, Britain finally got Spain, Portugal and the Netherlands to sign agreements on mutual search of each other's vessels and to establish tribunals to try slave merchants. The tribunals was a successful enterprise as the number of slaves freed by them was as much as $80,000.159$

Paul Gordon Lauren has also called the abolitionist movement a human rights movement. ${ }^{160}$ However, critics like Reza Afshari have noted that it was unlikely that the abolitionists had a larger scheme of human rights in mind. ${ }^{161}$ Moreover, even when the abolitionist debates included different forms of rights language, can they be meaningfully compared with present-day understandings of human rights? ${ }^{162}$ The greatest problem with Martinez's book is that it tells the story of abolitionism mainly as a triumph of moral values. However, there were many other considerations as well, such as economic and imperialistic.

A century later, during the League of Nations period, the same considerations were still on the table. Discussions on slavery were a balancing act between benevolence, economy and practical matters. The rights of individual slaves were not discussed. The idea of universal human rights and of human rights as inalienable and indivisible would only appear after the Second World War. The abolitionist movement was a single-issue movement, and could be said to show expressions of pity, benevolence and compassion rather than a human rights conscience, not to mention the equality of all human beings. ${ }^{163}$ For example, Lord Lugard, an opponent of the principle of slavery, wanted to abolish the practice gradually, avoiding excessive disturbance to the economic life of the society. ${ }^{164}$ Thus, the human rights of individual slaves were not under discussion, but rather the general effects to the economy and safety of societies.

Not even the abolitionists were free of the racism that was typical of the $19^{\text {th }}$ and $20^{\text {th }}$ centuries. Most abolitionists did not envision the slaves as having a role in their own liberation. The movement was instead about the Europeans' sense of

\footnotetext{
159 Martinez, The Slave Trade and the Origins of International Human Rights Law, 85.

${ }^{160}$ Lauren, The Evolution of International Human Rights: Visions Seen, 39.

161 Afshari, 'On Historiography of Human Rights: Reflections on Paul Gordon Lauren's The Evolution of International Human Rights: Visions Seen'.

162 Alston, 'Does the Past Matter?', 2051.

${ }^{163}$ Afshari, 'On Historiography of Human Rights: Reflections on Paul Gordon Lauren's The Evolution of International Human Rights: Visions Seen', 10-14.

${ }^{164}$ Lord Lugard spent his early career fighting against slavery: "Of all African problems there is none more engrossing than that of slavery, and ... to assist its solution has been the consistent object of my efforts since I first entered tropical Africa in $1888 \ldots .$. Lugard, The Dual Mandate in British Tropical Africa, 354.
} 
morality, about benevolence and paternalism, with the Europeans as givers and the Africans as takers. ${ }^{165}$ The abolitionists were far from envisioning the victims of slavery as true equals.

Despite their paternalism, many abolitionists referred to the humanity of the Africans. Naturally, this does not make abolitionism a human rights movement nor is it contradictory with paternalism. What did conflict with any budding human rights idea (and slow down the abolition process) was the fact that slaves were considered property. Thus, the slaves' right to freedom was in conflict with the owners' property rights. The latter were victorious in this conflict, as they were compensated for their loss even during the League of Nations period, but compensation for former slaves was never under consideration.

There was also the fear that freeing slaves would cause social unrest (and this idea was apparent during the League period as well). The individual rights of slaves were secondary to societal peace. Nor were black slaves believed to be able to manage on their own. Custody was thus moved from the slave owners to the colonial governments and then on to the mandatory administration.

\subsection{Forced Labour}

The prohibition of slavery, especially when it could be seen as a native vice, was easy. No such moral clarity existed in the question of forced labour. The purpose of this section is to examine how the conceptual and practical difficulties of colonial forced labour were faced in the debates in the PMC and within the mandates system in general. Forced labour was seen as a separate category and while, like slavery, it was prohibited by the Covenant, the grey areas surrounding forced labour were much larger. As a colonial practice, forced labour was also tied to the introduction of money economy, such as commercial farming in European plantations. When attempts at forcing the natives into salaried work failed, many colonial powers in the late $19^{\text {th }}$ and early $20^{\text {th }}$ century quietly introduced various practices to ensure the availability of labour force that may be interpreted as forced labour. Though forced labour was prohibited by the League Covenant, it was never seen in the PMC as a similar issue to slavery. The discussions over forced labour reveal convictions of morality, race and work in which assertions like the lazy native who needs to be forced to work were circulated. Various ways of working around the prohibitions of forced labour were devised, such as naming the labour obligations as tax or as traditional native customs resembling feudal obligations.

The price of labour vis-à-vis the economic developments were discussed at length after a questionnaire had been prepared to gain information on the labour conditions in the mandated territories. Especially the question of forced and compulsory labour raised heated discussion in the Mandates Commission. The

165 Afshari, 'On Historiography of Human Rights: Reflections on Paul Gordon Lauren's The Evolution of International Human Rights: Visions Seen', 20. 
rule relating to forced and compulsory labour in the mandates was that the mandatory ought to prohibit all forms of "forced labour except for essential public works and services, and then only for adequate remuneration". 166 But how then was this rule to be interpreted?

The differences of view within the Commission were vast. The question was how to balance the needs for the economic development of the territories and the amount of work reasonably required from the inhabitants. Frederick Lugard and Freire D'Andrade represented the two ends of the debate. According to Lugard, the African native was generally industrious and hard working. He maintained that "economic development was most necessary but it must take a secondary place, since it was dependent on the labour supply and the increase of the native population”. ${ }^{167}$ But Freire d'Andrade, for instance, did not agree with the industriousness of the natives and believed that generally the native was not very keen on work. ${ }^{168} \mathrm{He}$ considered that natives in general would regard work as something beneath their dignity, that most of the hard work was left to women, and that it was the duty of the mandatories to change this attitude. He believed that some of the races might disappear due to their lack of work capacity. However, he said: "as regards the other races, it was essential to require from them work which they were able to give in order to assist the mandatory power with the mission with which it was entrusted under the Covenant. This mission would not be accomplished if the mandatory power contented itself, for philanthropic reasons, with leaving the natives to drink and to indulge in endless debates and inactivity, under the pretext that they were happier in this mode of life and that it must be respected." 169 Orts pointed to the necessity of balancing between the two duties of the mandatories, namely the duty to develop the mandate and the duty of securing the welfare of the natives. As he believed that there were native races that did not (yet) have the capability for hard work, he believed that these two duties were in contradiction with each other and needed to be reconciled. He was also worried about "the intensive way in which certain tropical regions were being exploited". He noted a high death rate and that natives were returned to their villages permanently incapacitated or incurably ill due to hard work. ${ }^{170}$ However, he did not want to make the problem a (solely) humanitarian one: "the Mandates Commission had not the right to indulge in considerations which were exclusively philanthropic, but needed to take account of the practical aspects of the colonial problem as well as the moral aspect."

D'Andrade believed that the prohibition on compulsory labour could not mean that idle natives should not be forced to work because he believed that

\footnotetext{
166 See e.g. Mandate for German Samoa, Art. 3.

167 Minutes 6 (1925), 124-125.

168 Minutes 6 (1925), 47-50.

169 Minutes 6 (1925), 47-50.

${ }^{170}$ Minutes 6 (1925), 47.
} 
"work is a law of nature" and wanted to make idleness a punishable offence. ${ }^{171}$ In his view, vagrancy ought to be punished as it was punishable in civilized societies as well: "Compulsory labour, as I see it, is that which every living being is compelled to do or perish." ${ }^{172} \mathrm{He}$ stated in a note that it should be permitted to demand labour not only for public works but that it was equally necessary for private enterprises as well, because "for without them public works can be of little practical advantage". ${ }^{173}$

Forced labour was practised in all colonies. Forced labour was not disapproved of as slavery was. Its justifications, such as education, civilization, and the moral duty to work, were also different. ${ }^{174}$ Labour was described as an ennobling activity by some members of the PMC. Victorian notions of morality had contradictory views on slavery and forced labour. "Mutilation" by natives was resented, while corporal punishments for those trying to escape work were accepted as customary. ${ }^{175}$ Historically, slavery and forced labour were two sides of the same coin. Even when both had existed at the same time, the abolition of the slave trade and slavery led to an increase in forced labour. ${ }^{176}$ In the League of Nations politics, however, they were two separate issues. ${ }^{177}$

When the slave trade was largely abolished, a vast work force was suddenly free to work in Africa. A labour force was needed in the cotton fields, and now it was easy to find workers locally. This for its part helped to change the general opinion against slavery and to favour colonization. Cotton had been produced by former slaves in the colonies, and now their labour could be put to good use at home. ${ }^{178}$ The end of slavery brought about a new form of compulsion, which could sometimes be difficult to distinguish from slavery. ${ }^{179}$ Thus, as slavery had become inappropriate in a civilized state, forced labour was not and could even be held as desirable to advance the civilizational task.

The so-called "freedom villages" in the French colonies in what is now Sudan are revealing about the relationship between slavery and forced labour. These villages were set up for former slaves who had fled, been freed, or in other ways gained their freedom. The "freedom villages" offered a labour force to the Europeans and spouses to soldiers. If there were not enough labourers in the villages, the French sought for them in the neighbouring areas. The villages were

\footnotetext{
171 Minutes 7 (1925), 200.

172 Minutes 7 (1925), 202 and 203.

173 Minutes 7 (1925), 204.

${ }^{174}$ See e.g. Cooper, Decolonization and African Society.

175 Mamdani, Citizen and Subject: Contemporary Africa and the Legacy of Late Colonialism, 117.

176 Ibid., 148.

177 Miers, 'Slavery and the Slave Trade as International Issues 1890-1939', 27.

178 Mamdani, Citizen and Subject: Contemporary Africa and the Legacy of Late Colonialiom, 37.

179 Ibid., 38.
} 
dissolved between 1905 and 1910, when forced labour became more regulated and there were also other means to find labourers. ${ }^{180}$

Drawing the line between slavery and forced labour was not always easy in the mandates either. Rappard suggested that the labour conditions in New Guinea were "half-way between absolute freedom and absolute lack of freedom", 181 and Lugard noted that conditions similar to slavery existed in Togoland. ${ }^{182}$ One worry was the transition from slavery to paid labour. Where would the natives find the motivation to work if they did not need money? What if they did not wish to buy food or clothes? ${ }^{183}$

Article 22 of the League of Nations Covenant was silent on the question of forced and compulsory labour. It was, however, regulated in the separate provisions concerning the $\mathrm{B}$ and $\mathrm{C}$ mandates. According to the regulation in the $\mathrm{B}$ mandates: "The Mandatory ... (3) shall prohibit all forms of forced or compulsory labour, except for essential public works and services, and then only in return for adequate remuneration; (4) shall protect the natives from abuse and measures of fraud and force by the careful supervision of labour contracts and the recruiting of labour." 184 The C mandates were briefer, stating only that "... no forced labour is permitted, except for essential public works and services, and then only for adequate remuneration". ${ }^{185}$

Article 23 of the Covenant was also relevant in issues regarding labour. According to this article, "the Members of the League a) will endeavour to secure and maintain fair and humane conditions of labour for men, women and children, both in their own countries and in all countries to which their commercial and industrial relations extend, and for that purpose will establish and maintain the necessary international organizations; b) undertake to secure just treatment of the native inhabitants of territories under their control; [etc.]."

The Mandates Commission did not discuss Article 23 at any length when talking about forced labour in the mandates, but D'Andrade nevertheless interpreted the article in this context. According to him, the first part of the article, the "fair and humane conditions of labour", did not apply to the natives, but the second part, requiring "just" treatment of natives, did apply to conditions of labour. ${ }^{186}$ However, D'Andrade maintained that the labour conditions set for the $\mathrm{B}$ mandates could be said to interpret paragraph b) of Article 23 of the

\footnotetext{
180 Ibid., 149.

181 Minutes 27 (1935), 29.

182 Minutes 18 (1930), 97.

${ }_{183}$ Lugard, The Dual Mandate in British Tropical Africa, 391.

${ }^{184}$ See eg. Article 4 of the Cameroons mandate.

${ }^{185}$ See eg. Article 3 of the Nauru mandate.

186 See The interpretation of that part of Article 22 of the Covenant which relates to the well-being and development of the peoples of mandated territories, Note by M. Freire D’Andrade, Minutes 7 (1925), Annex 12, 198.
} 
Covenant to a certain extent. ${ }^{187}$ Lugard believed that Article 23 was concerned "only with labour and not with 'other matters'”, but he too believed that natives required "just" treatment in all matters. ${ }^{188}$

The third instrument relevant to the labour issues was Article 421 of the Versailles Treaty of June 28, 1919,189 part of section XIII which established the International Labour Organization (ILO) and called for social justice as the prerequisite for peace. ${ }^{190}$ According to Article 421, the parties to the treaty committed themselves to apply the labour conventions they became part of to their colonies as well, albeit with some restrictions:

The Members engage to apply conventions which they have ratified in accordance with the provisions of this Part of the present Treaty to their colonies, protectorates and possessions which are not fully self-governing:

(1) Except where owing to the local conditions the convention is inapplicable, or

(2) Subject to such modifications as may be necessary to adapt the convention to local conditions.

And each of the Members shall notify to the International Labour Office the action taken in respect of each of its colonies, protectorates and possessions which are not fully self-governing.

Thus, the labour treaties binding the mandatories applied to the mandates as well.

Part XIII of the Versailles treaty was included in the discussions on the labour issues through the questionnaire prepared by the PMC to ease the task of writing the reports for the mandates. One part of the questionnaire posed the question whether measures had been taken to ensure "in accordance with Part XIII of the Treaty of Versailles, the taking into consideration of conventions or recommendations of International Labour Conferences". ${ }^{191}$ It was also followed in subsequent reports whether the mandatories had reported this, and during the third session Harold Grimshaw from the ILO reported that there were three territories under $\mathrm{C}$ mandates where the "conditions of labour are not yet such as to allow the application of the decisions of the International Labour

187 The interpretation of that part of Article 22 of the Covenant which relates to the wellbeing and development of the peoples of mandated territories, Note by M. Freire D'Andrade, Minutes 7 (1925), Annex 12, 202.

188 The interpretation of that part of Article 22 of the Covenant which relates to the wellbeing and development of the peoples of mandated territories, Note by Sir F. Lugard on the Memorandum of M. Freire D'Andrade, Minutes 7 (1925), Annex 12a, 206.

189 Part I forms the Covenant of the League of Nations, whereas part XIII concerns labour issues and the establishment of the ILO.

${ }^{190}$ See preamble to part XIII, Versailles Treaty of June 28, 1919.

191 Minutes 2 (1922), Annex 2, 81. 
Conference". ${ }^{192}$ On the other hand, the administration of Tanganyika reported that "views of the International Labour Conference express the fundamental principles on which any labour-controlling legislation would be enacted, due regard being paid to native habits, customs and prejudices". Grimshaw noted that "this would be the correct attitude". ${ }^{193} \mathrm{He}$ also pointed out that the terms of the Versailles Treaty already in themselves provided the necessary elasticity for application. ${ }^{194}$ Upon questioning the New Zealand representative on the lack of application of the conventions and recommendations of the International Labour Conferences, the representative replied that the same regulations applied to Samoa as were in force in New Zealand and that New Zealand was in this regard more advanced. However, he noted that the "Administration only applied those regulations of New Zealand which had a practical application in the Islands." 195

The question whether the conventions regarding labour were applied in the mandates were handled through the reports to the Permanent Mandates Commission. However, as with slavery, it was difficult to acquire objective information about the existence of forced labour. In many instances the mandatories were praised for their efforts in enforcing the labour conventions by drafting laws that could be applied locally. Grimshaw, for instance, applauded Tanganyika for the development of its labour laws ${ }^{196}$ as well as the Cameroons for applying the international labour standards. The PMC also reminded the British Cameroons that the international conventions could be adapted to take local conditions into consideration. ${ }^{197}$ In the British Cameroons the Nigerian Labour Ordinance was applied to give the natives protection against European employees. ${ }^{198}$ Australia's representative explained that in New Guinea forced labour was not allowed even to the extent that it was in the other mandates because of Australian decisions and also because there was no need for a labour force for public works. He commented that: "The Australian Parliament had probably been actuated by motives of humanity... ." 199 However, Australia did admit that a certain kind of forced labour was used in agriculture. ${ }^{200}$

The questions on labour conditions applied to the A mandates as well. Palestine was to confine interference in private enterprise, as far as possible, within the limits imposed by international obligations, e.g. international labour

192 Comparative Statement concerning Matters Appertaining to Labour and Slavery in Territories under Mandate, Report by Mr. Grimshaw, Minutes 3 (1923), Annex 5, 266.

193 Ibid.

194 Ibid., 267.

${ }_{195}$ Minutes 7 (1925), 23.

196 Minutes 15 (1929), 121.

${ }^{197}$ Minutes 16 (1929), 92.

198 Minutes 16 (1929), 93.

${ }^{199}$ Minutes 18 (1930), 64.

${ }^{200}$ Minutes 18 (1930), 70 - 
conventions. ${ }^{201}$ Palestine adopted the Forced Labour Convention. ${ }^{202}$ Iraq was member to at least the Convention against slavery, and the Baghdad penal code regulated matters relating to slavery. ${ }^{203}$ Iraq's independence brought about the question of what would happen to labour treaties when the mandates ceased to exist or other changes regarding the mandated territory occurred. In Iraq the treaties continued to exist unchanged, as Iraq had already been treated as a political entity during the time the treaties were ratified. In Palestine, however, treaties ratified by England were applied in accordance with an understanding of Article 421 of the Versailles Treaty concerning the application of conventions to colonies. Palestine was not a contracting party to the convention, but the provisions were applied to it under certain conditions. ${ }^{204}$ Therefore, different rules applied to Palestine than were applied to England. The PMC disagreed about what would happen if the status of Palestine changed, either by dividing it into two parts or by gaining independence (the latter was not considered timely). William Weaver of the ILO believed that Palestine would start anew, because it had not bound itself by these treaties and could therefore choose what it would want to be a party to. Rappard maintained that there were differences between international labour treaties and other treaties. ${ }^{205}$ Penha Garcia noted that when a nation became independent, it would usually become a member of the League of Nations, and as a member would become a party to certain treaties. ${ }^{206}$

Through reports from the mandates and the questioning of the representatives, the Permanent Mandates Commission tried to make sense of how the clauses on forced labour were applied. Certain labour was allowed: for public purposes labour could be demanded if it was compensated. The kind of labour regarded as "public" was commonly road construction and cleaning. For instance, in the French Cameroons forced labour in 1938 comprised mainly road construction, which all natives were required to do for 10 days a year. The administration compared this to a communal service tax. Forced labour was regulated by a decree of compulsory labour, which dated to 1938 in this case. ${ }^{207}$

${ }^{201}$ Minutes 20 (1931), 107.

202 Minutes 27 (1935), 69.

${ }^{203}$ Minutes 16 (1929), 39.

204 Treaty of Versailles, Article 421: "The Members engage to apply conventions which they have ratified in accordance with the provisions of this Part of the present Treaty to their colonies, protectorates and possessions which are not fully self-governing:

(1) Except where owing to the local conditions the convention is inapplicable, or

(2) Subject to such modifications as may be necessary to adapt the convention to local conditions.

And each of the Members shall notify to the International Labour Office the action taken in respect of each of its colonies, protectorates and possessions which are not fully selfgoverning."

${ }^{205}$ Minutes 32 (1937), 123-124.

206 Minutes 32 (1937), 123-124.

${ }^{207}$ Minutes 37 (1939), 113. 
However, matters were not always so clear. What if the roads led to a village and their upkeep was demanded by a village chief? This kind of labour was often considered "communal labour" and considered a native tradition done for the good of the chief or the village community. ${ }^{208}$ Lugard differentiated between social services (e.g. cleaning around huts, burying the dead, etc.) and labour (e.g. road cleaning). Social services did not require compensation, labour did. ${ }^{209}$ Lugard wanted to see the total prohibition of all forms of unpaid labour: "To urge the sanction of native law and custom is absurd, for that customary law would sanction slavery and many other things contrary to humanity." ${ }^{210} \mathrm{He}$ added: "It is without question essential that, for whatever purpose compulsion may be resorted to, it should have the sanction of a law clearly defining the extent and conditions of the service required." 211 The British administration, however, believed that the unpaid maintenance of village roads at the command of chiefs was not compulsory or forced labour, but "traditional labour". The British believed that the natives' willingness to do "traditional labour" would diminish as the natives developed. The PMC nevertheless thought that the work was maintenance required by the administration, i.e. forced or compulsory labour. ${ }^{212}$ William Weaver of the ILO believed that villagers should be consulted before communal services could be demanded from them, but their permission was not required. According to him, it had been claimed that the Forced Labour Convention had set such criteria that it had been difficult to find people to take care of hygiene matters in the countryside. Thus, according to Weaver, the forced labour convention did not prevent social services and he was sorry that the convention was blamed for problems it did not cause. ${ }^{213}$

One of the reasons why it was so difficult to agree on the limits of forced labour was that much of it was done in the villages on behalf of the native chief. Even when the Commission took steps to ensure that natives did not abuse each other, it did agree that some of the work in the villages, being traditionally compulsory, was probably needed. This included weeding and cleaning around the villages. This was one of the reasons why Van Rees found a total prohibition impracticable: "[i]t would be impossible to comply with the terms of the mandates, which are not based on practical experience and therefore involve consequences of unforeseen extent”. ${ }^{214}$ Thus, in practice a grey area existed between public and private work.

\footnotetext{
208 Miers, Slavery in the Twentieth Century, 139.

${ }^{209}$ Minutes 24 (1933), 23; Lugard, The Dual Mandate in British Tropical Africa, 408.

${ }^{210}$ Ibid.

211 Ibid., 413.

${ }^{212}$ Minutes 15 (1929), 123-124.

${ }^{213}$ Minutes 30 (1936), 99.

${ }^{214}$ Minutes 7 (1925), 66 and 155.
} 
Certain work required by the chiefs was seen as unavoidable in order to secure the authority of the chiefs, and the administration was unwilling to limit the services required by the chiefs: "In a feudal society such as existed in the territory, the authority of the chiefs should be safeguarded by the maintenance of the labour service, which was at the basis of the traditional organisation." ${ }^{215}$ The work required by the chiefs consisted mainly of building huts and taking care of plots of land. ${ }^{216}$ Yet, there were worries about the luxurious lifestyles of the chiefs, which were supported by services from the villagers. ${ }^{217}$ "There was a certain parasitism to be abolished," noted Halewyck de Heusch, representing the Ruanda-Urundi administration. ${ }^{218}$ However, because the chiefs were accustomed to free labour, one needed to proceed carefully, he believed. ${ }^{219}$ Lugard raised the question of chiefs who were against the Forced Labour Convention and particularly its two clauses on personal services (Art. 7) and on compulsory cultivation in cases where there was a risk of famine or food deficiency (Art. 19), as they believed that "if these two paragraphs were retained, much feeling against them (the chiefs) would arise". 220 Thomas, representing British Togoland, replied that the chiefs referred to "personal services", for instance "such work as carrying the chief in his palanquin, or bearing the ornaments attached to the 'stool' on state occasions". ${ }^{221}$ He noted that it would have been impossible for the chiefs to require such services without the consent of his people. 222 Weaver noted that there was a penalty attached to the refusal to perform such services, granted in the Order by the Governor. In his view, such a penalty turned the services to forced labour according to the Forced Labour Convention. ${ }^{223}$ The mandatory administrations did not see work ordered by chiefs as a great problem and emphasized its customary nature.224

Even in cases where labour could be regarded as public, the task of finding the workers was often given to the local chiefs. This of course caused several problems in itself. The PMC was worried about the power that the chiefs had over the labourers and the possible recruitment methods. ${ }^{225}$ According to Lugard, it was also part of British colonial politics that workers were found through the village chiefs. However, the chiefs needed to be supervised. ${ }^{226}$ The reports of the Mandates show that the authority of the chiefs was a sensitive issue. Lugard

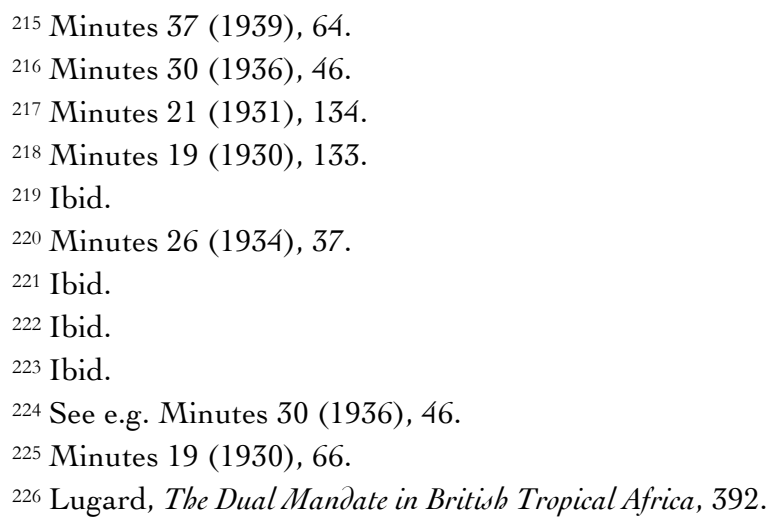


maintained that one problem concerning finding a labour force through chiefs was that if the labourer declined the work, he would openly question the authority of the chief. 227

An issue where native customs were referred to, was whether the chief would be entitled to the salary earned by a worker. In certain maintenance works in British Togo the salary was paid to the chief, as the administration noted that it was the native custom to do so and it would be laborious for the administration to do otherwise. 228 Also, the representative of Ruanda-Urundi believed that if chiefs started compensating the workers, it would weaken the chief's authority. ${ }^{229}$ Bonnecarrère, representing French Togoland, admitted that probably the chiefs forced natives to work, but one should not exaggerate the danger. He saw the chiefs as feudal lords, who offered protection rather than monetary compensation in exchange for work. ${ }^{230}$

Generally, the PMC (with the exception of D'Andrade) agreed that there was a need to protect the natives from forced labour to private actors. Halewyck de Heusch noted that "[f]orced labour was as hateful if required for private individuals as it was commendable when imposed on the natives to remedy their lack of foresight and induce them to produce the foodstuffs indispensable for their elementary needs". ${ }^{231}$ Lugard believed that the solution to the lack of work force for private employers could be "imported contract labour", which, however, did not differ much from recruiting workers from the same country but further away, which could cause its own social problems (both on account of separation of families and because large groups of rootless men were gathered in one place). ${ }^{232}$

Were labour levies (prestation in the French mandates) forced labour? For instance in the French Cameroons certain work was encouraged to be done as public labour, instead of having taxes collected from the natives. ${ }^{233}$ The discussion on labour levies highlights the differences of opinion in the PMC. The Commission's views were varied. They saw labour levies as a native custom and consequently they were not sure what to do.234 Lugard reminded his colleagues that it was the duty of the "European administration" to prohibit any actions contrary to its civilizing mission. ${ }^{235}$ The French administration defended labour levies, stating that the purpose of the clause prohibiting forced labour was decisive. According to them, the purpose was to avoid abuses and disguised slavery. It was probable that such abuses had occurred during the former

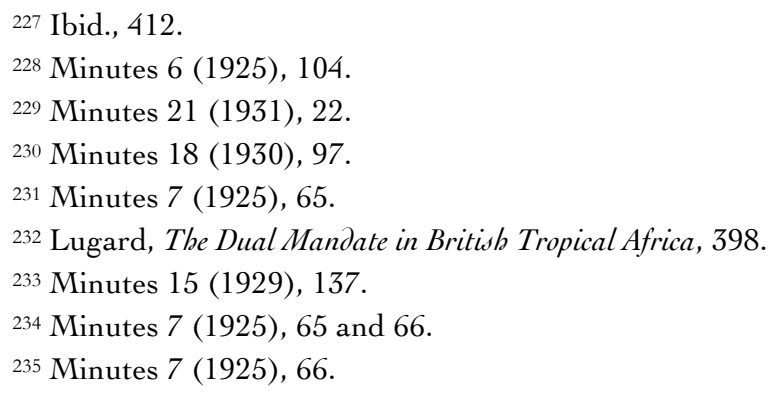


administration, but the tax was for "improvements advantageous to the natives". 236 Van Rees represented the view that the prestations were a common and useful colonial policy: "literal compliance with this clause [prohibiting forced labour] was impracticable. Anyone with experience of colonial life knew that there was always need for such labour... ." ${ }^{237}$ However, he realized that if the mandates clause was to be taken literally, the prestation would be against it: "if forced labour were exacted as a fiscal tax, it was nevertheless forced labour...”.238 D'Andrade agreed, noting that "a strict interpretation of the clause of the mandate in question would result in making impossible the execution of indispensable works in Togoland". ${ }^{239}$ He noted that all civilized countries, or at any rate Portugal, had such labour levies. ${ }^{240}$ Lugard, on the other hand, strictly opposed labour levies. He would not see taxes as justifiable unless the natives had proper means to earn wages to pay them. He emphasized that he would not compromise on the matter. ${ }^{241}$ Dannevig found it strange that men needed to work instead of paying taxes and then work even more in order to feed themselves. ${ }^{242}$ Rappard, the diplomat, concluded that "no criticism of the French Administration was implied", but creating a loophole to include forced labour in lieu of taxation could "enable unprincipled Governments to abuse the mandate".243

In labour matters the PMC was from early on confronted with one dilemma: "the Commission was agreed on the necessity of discouraging idleness in the mandated territories and simultaneously protecting the freedom of workers." 244 However, different members of the PMC emphasized different parts of this equation. D'Andrade was still very much part of the Portuguese colonial tradition: "The economic development of the country requires native labour, which must be adapted to its purpose." 245 "If he fails to [contribute to the well-being and development of peoples by work], and attempts to go on living under his present conditions, if he prefers his former habits of ease and idleness, then the Mandatory must intervene and give him to understand that work is a law of nature and that, in communities which hope to prosper, idleness is a punishable offence." ${ }^{246}$ D'Andrade did also see that there was a possibility that the administration would

\footnotetext{
236 Minutes 6 (1925), 17.

${ }^{237}$ Minutes 6 (1925), 16.

238 Minutes 6 (1925), 17.

${ }^{239}$ Minutes 6 (1925), 17.

${ }^{240}$ Minutes 6 (1925), 19.

${ }^{241}$ Minutes 6 (1925), 18.

242 Minutes 31 (1937), 46.

${ }^{243}$ Minutes 6 (1925), 18 and 20.

244 The Marquis Theodoli, Chairman of the meeting, Minutes 1 (1921), 14.

245 The interpretation of that part of Article 22 of the Covenant which relates to the wellbeing and development of the peoples of mandated territories, Note by M. Freire D’Andrade, Minutes 7 (1925), Annex 12, 200.

246 Ibid.
} 
require too much labour from the natives: "If a country is to be developed rapidly and this requires more labour than the country can supply in the normal course, there is a tendency to practise abuses upon the natives and to subject their habits and customs to abrupt changes, which cannot be made without some risk." ${ }^{247}$

Lugard's answer to D'Andrade's criticism was education and civilization. $\mathrm{He}$ agreed with the basic starting point: that natives should work and that all work should not be left to women. However, he did not believe in the idea of work as a law of nature as promoted by D'Andrade. He denied the existence of such a law in England, but noted that vagrancy (which he found to be different from idleness) was only punishable in England if there was criminal intent. The only way to change matters was education. ${ }^{248}$ D'Andrade, however, replied that he did not have the patience to wait: "But the education of the coloured man must take scores of years, even centuries." 249 Penha-Garcia, the Portuguese member replacing D'Andrade in the PMC, shared D'Andrade's view on forced labour. ${ }^{250}$

Some mandatories agreed on the advantages of forced labour. New Guinea's representative noted that the country had just been lifted from the Stone Age. People would need to learn to work in order to survive the modern age. Thus, making the natives work was part of the "sacred trust" of taking care of their wellbeing. Unless their work was overseen, they had a natural tendency to avoid it: "In the villages the natives were seen at their worst; on the plantations, at their best." ${ }^{251}$ The South African representative denied that there was forced labour in the reservations of South West Africa: "there was not: but he always impressed on the natives that the reserves had not been set aside to enable them to lead a lazy life. The Europeans worked, and so should they." ${ }^{252}$

D'Andrade believed that the duty to work emanated among other things from the fact that the natives owed a debt of gratitude to the administration, for if "civilization steps in to protect the natives in their own country against abuses against which they could not defend themselves, it was only right to exact from them in turn an effort equivalent to what was done in their interests". ${ }^{253}$ Lugard disagreed with those claiming that African men were lazy by nature, leaving the women to work, while they themselves idled in the sun, eating and drinking. According to Lugard, few races were more hard-working: "the fertility of the soil,

\footnotetext{
247 Ibid., 202.

248 The interpretation of that part of Article 22 of the Covenant which relates to the wellbeing and development of the peoples of mandated territories, Note by Sir F. Lugard on the Memorandum of M. Freire D'Andrade, Minutes 7 (1925), Annex 12a, 206.

${ }^{249}$ The interpretation of that part of Article 22 of the Covenant which relates to the wellbeing and development of the peoples of mandated territories, Reply by M. Freire D'Andrade on Sir F. Lugard's Note, Minutes 7 (1925), Annex 12b, 207.

${ }^{250}$ Minutes 20 (1931), 23.

${ }^{251}$ Minutes 20 (1931), 20-22.

252 Minutes 31 (1931), 140.

${ }^{253}$ Minutes 1 (1921), 14.
} 
his few wants, the physical capacity of his women for manual work, are all prompting causes for idleness, yet except when relegated to reserves, or when his status as a slave deprived him of all incentive, he is usually industrious." 254 It was also discussed whether there was a difference between compulsory labour and forced labour. D'Andrade believed that the first one had to do with preventing idleness (where the "real forced labour" was done by the wives), while the latter (meaning going to native villages, taking the natives and escorting them to work) was forbidden to protect the natives. "Native labour was most necessary in order to promote civilisation and progress among the natives themselves," he claimed.255 According to him, the difference could be reconciled letting the native choose the type and place of work, as long as he did not refuse to work. ${ }^{256}$ Lugard did not think education should be the primary reason for using force. Forced labour was justified only when workers could not be found for essential and hurried public tasks. ${ }^{257}$ Palacios explained, contrary to what Penha-Garcia had stated, that the PMC's interest in labour conditions was not whether the natives had a duty to work, but rather that, when they did work, they could be abused. If the abuser was a private actor, then the responsibility was with everyone who was a "guardian of civilisation", including teachers, doctors and missionaries. If the abuser was the administration, this could require "international intervention in the interests of humanity". ${ }^{258}$ In Palacios's view, "there were very few subjects which lent themselves better than labour to conciliatory and civilising efforts". ${ }^{259}$ While the members of the PMC had different attitudes towards forced labour- the reasons why it should be prohibited or accepted, the capabilities of the natives as workers, and their duty to increase the overall wealth of the territory - they all shared one common idea. For them, the inhabitants were not active participants in their own destinies, working to maintain their families. Rather, they were treated as passive receivers of education, civilization, or at best, humanitarian protection from abuses by the stronger, be it the village chief, a private enterprise or the mandatory administration.

Many of the problems relating to labour conditions could be explained by the different customs of the natives and by the difficult conditions in the mandates. In general, Lugard maintained that the whole problem of slavery and forced labour derived from the undeveloped state of social organizations, and from the lack of written contracts and money. Whipping employees in New Guinea took place even though it was not tolerated. The administration found it difficult to prevent isolated cases. Work safety was compromised because of the natives' lack of

${ }^{254}$ Lugard, The Dual Mandate in British Tropical Africa, 401.

255 Minutes 1 (1921), 31; Minutes 5 (1924), 137.

256 Ibid.

${ }^{257}$ Lugard, The Dual Mandate in British Tropical Africa, 411.

${ }^{258}$ Minutes 16 (1929), 104.

${ }^{259}$ Minutes 7 (1925), 119. 
understanding: "[t]he difficulty was that the natives often refused to use safety devices". ${ }^{260}$ The work, timely payment of salaries and improvement of working conditions were more difficult because of the natives: "[ $t]$ he attitude of the employee himself, who was a gambler, anxious to participate in the rather interesting and amusing work of alluvial gold washing, content to take his bonus in good times and to wait for his pay in bad times." ${ }^{261}$ Even malnutrition could be blamed on the natives. The reason for malnutrition was not lack of food, but the fact that the administration had not yet succeeded in teaching the natives to improve their diet. The PMC had to remind the different administrations that they should not let the lack of enthusiasm on the natives' side prevent improvements.

Native customs could also be used to get around questionable practices. Mahmood Mamdani describes the use of corporal punishment in colonial practice. The British had prohibited whipping by Europeans after the First World War, the French after the Second. The chiefs could, however, continue the practice because of its customary nature. This was rather useful if labourers needed to be disciplined for one reason or another. ${ }^{262}$ Treating the natives as children justified corporal punishment. ${ }^{263}$ The convenient solution to the balancing between moral demands and the customary consideration of natives as minors was to let the native authorities give the punishments whenever possible. ${ }^{264}$

As with slavery, Lugard believed that the British had a lot to teach others concerning the fair treatment of labourers: "It is all-important that the man who actually handles the labourers should possess those instincts of fair-play and tolerance which we like to think are eminently British, and that he should have the knack of getting on well with his men. For the man they like, Africans will do double the work they will for another."265

A representative from the International Labour Office (ILO) was mainly present at the discussions on labour issues. Director Albert Thomas of the ILO reminded the PMC of the duty to apply labour conventions to colonies and non self-governing protectorates. ${ }^{266}$ Thomas agreed that there were facts to take into account, even when there was an absolute prohibition of forced labour, such as Article 421 (of the Versailles Treaty), which required just and humane labour conditions. ${ }^{267}$ Theodoli, the Chairman of the PMC, and Thomas applauded the collaboration between the PMC and the International Labour Office, describing

\footnotetext{
260 Minutes 31 (1937), 45.

261 Minutes 34 (1938), 148.

262 Mamdani, Citizen and Subject: Contemporary Africa and the Legacy of Late Colonialiom, 287.

263 Ibid., 159.

264 Ibid., 158.

265 Lugard, The Dual Mandate in British Tropical Africa, 406.

266 Minutes 1 (1921), 30.

267 Minutes 1 (1921), 30-31.
} 
their common object as the "noble" one of "improving the condition of the labouring classes, whatever their colour might be”. ${ }^{268}$

During the interwar years, forced labour was largely seen as a colonial problem. ${ }^{269}$ Reports on drastic work force conditions in a number of colonies brought about the idea of a legal regime to control forced labour and to give content to Article 23 of the League of Nations Covenant, something that had not been achieved in the drafting of the slavery convention. ${ }^{270}$ The rhetoric used in the drafting process, which was mainly shaped by colonial insiders, was similar to that of the mandates. Notions such as "trusteeship" and "civilization" were used and harsh criticism was avoided. ${ }^{271}$ The ILO also saw as its task to bring civilization and development to the colonies ${ }^{272}$ and Harold Grimshaw, a British lawyer and the director of the Native Labour Division at the ILO, was also an active participant in the PMC. Other ILO experts were also active in the mandatory administration. ${ }^{273}$ The 1929 session of the International Labour Conference in Geneva revealed the colonizing states' reluctance to control forced labour. The Portuguese, for instance, talked of forced labour as a "benevolent tool". What was finally agreed upon was that "the ILO stood firmly against forced labour, but was supportive of the need to civilize indigenous subjects". ${ }^{274}$ During the time the mandates existed, Britain and France were the only mandatory states to ratify the convention on forced labour in the late 1930s. ${ }^{275}$

During the debates of the PMC and in the practices of the League mandates administration, the absolute prohibition of forced labour never gained a similar status as that of slavery. Much of this may be explained by the pervasive idea of the morality of work, where labour was seen as part of the civilizing mission and development. Proponents of forced labour were adamant that its use would be a benevolent tool to advance the goals of development. The civilizing mission was seen as more important than the individual freedom of the native.

\footnotetext{
268 Minutes 1 (1921), 32.

269 Daughton, 'ILO Expertise and Colonial Violence in the Interwar Years', 86; Maul, 'The International Labour Organization and the Struggle against Forced Labour from 1919 to the Present', 478.

270 Maul, 'The International Labour Organization and the Struggle against Forced Labour from 1919 to the Present', 480.

${ }^{271}$ Daughton, 'ILO Expertise and Colonial Violence in the Interwar Years', 86.

272 Ibid., 87.

${ }^{273}$ Ibid., 88.

${ }^{274}$ Ibid., 89.

275 Ibid., 90; Daniel Roger Maul states that only Britain ratified it. Maul, 'The International Labour Organization and the Struggle against Forced Labour from 1919 to the Present', 483.
} 


\subsection{Land Tenure}

The focus in this section is on issues of land rights and land tenure in the mandates. Within the colonial system, land tenure was a fundamental point of contention between the indigenous population and the settlers. Settler colonialism, as has been recognized in studies on indigenous dispossession, operated through the transfer of land from the indigenous population to European settlers. The issue of land tenure was thus a principled one, but as we shall see, very little idealism was present in the debates of the Mandates Commission. Instead, old colonial practices were continued and introduced into the mandated areas. The preoccupations of European colonialism, such as the introduction of private land ownership under the guise of development, the imposition of Western land law and land registries, and negative attitudes towards indigenous communal tenure, were rampant. Like in the British colonial administration, the PMC oversaw situations where the administration became the owner of the land as a trustee, thus in practice transferring indigenous land to European government. One of the economically most important issues was land tenure and the protection of land rights. As in the European colonies, there were tensions between the interests of European settlers and the indigenous populations. ${ }^{276}$

Under the mandates system, all B mandates included a provision regarding land legislation. According to the article on land legislation (which was similar in all B mandates):

In the framing of laws relating to the holding or transfer of land, the Mandatory shall take into consideration native laws and customs and shall respect the rights and safeguard the interests of the native population.

No native land may be transferred, except as between natives, without the previous consent of the public authorities, and no real rights over native land in favour of non-natives may be created except with the same consent.

The Mandatory will promulgate strict regulations against usury.277

The article has an inherent contradiction. On the one hand, it asks the mandatories to support and respect indigenous systems of land tenure, while on the other it imposes the so-called inalienability clause. As a result, the policy was very similar to those of enlightened paternalistic colonialism, where the indigenous peoples were in practice wards of the state or minors: protected but with limited rights.

It was the duty of the mandatory to give regulations on how land was administered in the mandates. In 1923 the Mandates Commission gave a report on

${ }^{276}$ Hickford, Lords of the Land; Banner, How the Indians Lost Their Land.

${ }^{277}$ See e.g. British Mandate for Cameroons, Article 5. 
how the regulations differed in the various mandates. The conclusion of this report was that in the mandates examined by this report, land was administered as the mandates treaties required. The report aimed to determine how exactly native rights and customs should operate in the land system. The rapporteur, van Rees from the Netherlands, concluded that it was in the true interests of the natives that land legislation was based on Western law. Western law would protect them "against their own ignorance, and [safeguard] their interests in the land", as opposed to native legal conceptions, which were the "result of ancient customs and usages". 278 Van Rees's conclusion was that the article was not to be taken to mean that native customs should be applied literally, but that the mandatories needed to "respect such genuine native rights as had been practically demonstrated in virtue of their customs and uses and to guarantee their interests, both immediate and more remote". ${ }^{279}$

The administration was not seen as a threat to native land rights, but as a trustee, the guarantor of "genuine native rights". In Samoa, for instance, there was a provision according to which "[a]ll land in Samoa which at the commencement of this Act is held by Samoans by native title is hereby vested in the Crown as the trustee of the beneficial owners ...". ${ }^{280}$ According to the PMC, the threat to the lands came from the inhabitants, who could not understand the complexities of modern ownership. Intervention was needed "to protect a person of no capacity or a minor - the native - from impulses which might induce him to effect a disastrous alienation". Also, without government intervention, "an occult, irregular and precarious right of ownership" might be constituted, "which would be a source of profound and lasting disturbance to public order and future colonization".281 Therefore, in the event that land needed to be ceded, the authorization from the government was always necessary. In New Guinea restrictions existed on the native populations concerning land sales, meaning that they could not sell land. McLaren noted that this was "a very necessary safeguard of the rights of native landowners".282

Later, Jules Repiquet, the French Cameroons representative, was questioned about the land registration system in the Cameroons. According to the PMC, the system had become rather bureaucratic. Could a simpler system be applied? Repiquet noted that the problem was the "strong individualistic tendencies" of the natives. It was simply too difficult to make the natives understand the importance of land registration. The administration would "welcome any method of attaching him to the soil". ${ }^{283}$

278 Minutes 3 (1923), Annex 2, The System of State Lands in B and C Mandated Territories, Report by M. van Rees, 227.

279 Ibid., 228.

${ }^{280}$ Samoa Act 1921, Article 278, cited in ibid., 229.

${ }^{281}$ Report on the Administration of Cameroons, cited in ibid., 230.

282 Minutes 23 (1933), 31.

${ }^{283}$ Minutes 30 (1936), 42. 
There were worries that registration might lead to the native being dispossessed of his land. ${ }^{284}$ Hailey thought that land registration was in direct opposition to the common property of the tribe and the family,285 and Van Asbeck noted that one of the aims of land registry had been "freeing native property from the customary rules". 286

What was the effect of land registration? Did it lead to dispossession and mortgages, the latter being one of "two aspects of the same evil" along with money-lenders, as Van Asbeck saw it, or a safeguard leading to stability amongst the natives?287 Van Asbeck pointed out that one could not compare registration in Europe and amongst the natives. The latter were not accustomed to the liberty of disposing of their property and needed protection and guidance in order not to commit any rash acts. Europeans were needed to control their actions. ${ }^{288}$

Land issues were approached through ownership. Lugard understood land ownership as a process of "natural evolution", that was not to be arbitrarily interfered with. Such a process could best be supported with a "policy of patient progress", which meant that principles and laws strange to the inhabitants of colonies should not be introduced but rather let changing circumstances and social progress lead to a path of natural evolution that would finally result in private ownership. ${ }^{289}$ Van Rees noted in his report on the land system that the problem of the mandatory was that "private property and the sale of land ... are conceptions which are totally unknown and appear to them unthinkable". ${ }^{290}$ D'Andrade's interpretation on the rights and duties regarding native land was that: " $[t] h e$ necessary agricultural land must be reserved for the natives, and they must be secured in possession, at the same time being trained by instruction and example to derive the utmost possible profit from the land."291 Bonnecarrère, representing French Togoland, noted that the natives are getting "more and more used to the idea of property". ${ }^{292}$ Besson explained an improvement in land ownership in the French Cameroons, where a native might become a landowner, "subject solely to observance of the rules of allocation and inheritance laid down by local custom". There would then be a "third stage" of land evolution, where a system for land registration would be set up. This would enable the regulation of land "in

\footnotetext{
284 Minutes 30 (1936), 43 and 82.

${ }^{285}$ Minutes 30 (1936), 43.

286 Minutes 30 (1936), 43.

${ }^{287}$ Minutes 30 (1936), 82.

${ }^{288}$ Minutes 30 (1936), 82.

${ }^{289}$ Lugard, The Dual Mandate in British Tropical Africa, 280-285.

290 Minute 3 (1923), Annex 2, The System of State Lands in B and C Mandated Territories, Report by M. van Rees, 228.

291 The Interpretation of that part of Article 22 of the Covenant which Relates to the Wellbeing and Development of the Peoples of Mandated Territories. Note by M. Freire D'Andrade. Minutes 7, (1925) Annex 12, 204.
}

${ }^{292}$ Minutes 18 (1930), 101. 
accordance with the most modern ideas". ${ }^{293}$ Within colonial regimes privatization of land and the establishment of land registries were commonly seen as preconditions of progress and modernization. 294

Van Rees in his report did, however, express worries that protecting the natives in land matters could go too far. Using Samoa as an example, he asked if the land provisions prohibiting any land sales by the natives and the government receiving the rent in the native's name would actually take away all their independence. ${ }^{295} \mathrm{He}$ also approached the question of the natives' "right to roam" and "the right of gathering" and concluded that there was a genuine conflict between the mentioned rights and the need of a government to put all lands under its exclusive control. This conflict should be solved in a just manner: “... as in the application of every fundamental principle, the declaration of State property will ... have to be applied not only in an equitable manner but especially with wisdom and humanity." 296 The members of the PMC lectured the Japanese representative on the differences between communal ownership and communal usage, reminding him that mixing these had caused considerable problems in Africa, ${ }^{297}$ as well as on appeal routes on land rights and the differences between a court process and an administrative process. ${ }^{298}$

Native land rights were seen at the Permanent Mandates Commission as both a legal and a social question, which touched upon issues of indigenous communalism in a similar manner as in colonial regimes. ${ }^{299}$ In Samoa, the New Zealand administration believed that the abolition of communal ownership of land would serve the development of the territory and the natives. New Zealand claimed that it was in the interests of the natives that native laws and customs would be changed. They regarded the principal disadvantage of the communal system to be that "the energetic individual was at the mercy of his lazier fellows". ${ }^{300}$ Therefore, it was aimed to put a new system in its place. All adults would receive a piece of land for their own use on their eighteenth birthday, and each individual would have the obligation to cultivate it. 301 The same argumentation on the problems of communal ownership was used in the A mandates as in the $\mathrm{B}$ and $\mathrm{C}$ mandates. As the French noted, their motivation for a land reform in the Jebel Druse area of Syria was to direct it "against that part of

\footnotetext{
${ }^{293}$ Minutes 24 (1933), 46.

${ }^{294}$ Peters, 'Challenges in Land Tenure and Land Reform in Africa', 1317-18.

295 Minutes 3 (1923), Annex 2, The System of State Lands in B and C Mandated Territories, Report by M. van Rees, 232.

296 Ibid., 238.

${ }^{297}$ Minutes 30 (1936), 187.

298 Minutes 30 (1936), 188.

299 See Richter, 'Land Law in Tanganyika since the British Military Occupation and under the British Mandate of the League of Nations'.

300 Minutes 7 (1925), 30.

301 Minutes 7 (1925), 30.
} 
the population which did the least work and against the chiefs whose continuous desire was to take the best-cultivated lands themselves". ${ }^{302}$

The PMC paid attention to the amendment of the "Land and Native Rights Ordinance" (1928) of Tanganyika, which included a "right of occupancy" giving the natives or native community "lawfully using or occupying land in accordance with native law and custom", that was however conditional in the sense that it was "revocable for good cause" and "for a specific period only". The PMC noted that because of these limitations, the ordinance did not "confer upon a native community any permanent and inalienable title to their ancestral lands". 303

In no other issue than that of land tenure was the mandates system and the PMC more like European colonialism. While problems of indigenous dispossession had been recognized in the more enlightened colonial systems, the old colonial hands running the PMC were mostly blind to it. Colonialist policies, such as introducing fixed property rights and private ownership of lands, and conversely, the phasing out of communal ownership of land, were done under the guise of progress. The effects of these policies, such as indigenous dispossession, were mentioned only occasionally. Doctrines which elsewhere had proven to be devastating for indigenous land rights, such as the obligation to cultivate and the idea of vacant lands reverting to the crown, were discussed as viable policies. Like in the colonial settler states, the only alleviative measures to indigenous dispossession were the restrictions imposed on the sale of land (restrictions that in many settler states had only further strengthened indigenous dispossession). Finally, the introduction of land registries, which contributed to indigenous dispossession by making ownership conditional on an administrative act by the government often beyond the reach of the indigenous population, was promoted as a tool for economic progress.

\subsection{Women}

The position of women and women's rights were a political and conceptual minefield for the League of Nations mandates system. The political struggle for the equal position of women was even in Europe on-going, and thus it was fairly normal and accepted that women were under guardianship or did not have the vote. However, the position of women was one of the main themes of the so-called enlightened colonial discourse. In the following, we will see how colonialist and feminist themes were mixed in the way that the PMC set out to understand the position of women in the mandated territories. The themes of civilization and progress were raised as future hopes for the eradication of native customs such as female circumcision and child marriage, and polygamy that was repeatedly compared with forms of slavery.

\footnotetext{
302 Minutes 8 (1926), 102.
}

${ }^{303}$ Minutes 22 (1932), 157. 
The question of women (and often interrelatedly, children) ${ }^{304}$ and their rights had been raised on several fronts in the League of Nations. First of all, there was the drafting process of the convention concerning the trafficking of women and children. ${ }^{305}$ The League of Nations had an Advisory Committee on the Traffic of Women and Children in operation from 1921 to 1936. International feminists could question the position of women by tackling the issue of prostitution and sex trafficking, 306 and trafficking of women had been the subject of two international conferences in 1899 and 1913, while two international treaties were drawn up in 1904 and 1910. The League took the issue under its authority and held a conference on the topic in 1921. The international feminists had a comparatively strong foothold in the Advisory Committee. Jessica Pliley has described how the feminist agenda changed throughout the years depending on who served on the Committee. ${ }^{307}$ The Committee had a larger number of female participants than any other Committee in the League. Apart from sex trafficking, international feminists sought to bring forward different aspects of female subordination and gender inequality, including the question of women's nationality.

Secondly, in general, the question of equality between women and men had been raised in the League of Nations. A feminist movement that was active in lobbying on questions relating to women in the League of Nations existed, and the question of equality was a key issue. There was a campaign for an Equal Rights Treaty, which, however, never materialized during the League period. ${ }^{308}$ However, the instigation of such a treaty kept questions of gender equality alive at the League. In general, countries did not show much sympathy towards demands for equal rights at the national level. Thus, it was only natural to bring questions to the international level, where activists hoped that issues relating to the "rights" of individuals were given the form of international obligations. ${ }^{309}$

\footnotetext{
304 On the perception of women as victims, requiring like children special protectionsee Hevener, 'International Law and the Status of Women: An Analysis of International Legal Instruments Related to the Treatment of Women'; Kapur, 'The Tragedy of Victimization Rhetoric: Resurrecting the "Native" Subject in International/Post-Colonial Feminist Legal Politics'. Peter N. Stearns maintains that the women's rights movement had an "essential component of human rights" (Stearns, Human Rights in World History, 111).

${ }^{305}$ Barbara Metzger argues that the Final Act of the 1921 Conference, adopted as a Convention, was "the first League Convention dealing with a human rights issue". Metzger, 'Towards an International Human Rights Regime during the Inter/War Years: The League of Nations' Combat of Traffic in Women and Children', 73.

306 Pliley, 'Claims to Protection: The Rise and Fall of Feminist Abolitionism in the League of Nations' Committee on the Traffic in Women and Children, 1919-1936', 91.

307 Pliley, 'Claims to Protection: The Rise and Fall of Feminist Abolitionism in the League of Nations' Committee on the Traffic in Women and Children, 1919-1936'.

308 Miller, "Geneva - the Key to Equality": Inter-War Feminists and the League of Nations'.

309 Ibid., 221.
} 
Advocates of women's rights believed that the problems encountered by women were shared between women around the world. They also believed that the "low position of women in more backward countries" hindered women in more "advanced" countries from gaining their rights, and therefore, international agreement was essential. ${ }^{310}$ Nevertheless, women's rights continued to be regarded as domestic issues, which were affected by cultural and religious traditions. ${ }^{311}$

Women also took an interest in colonial matters. Upper class or upper middle class women found their vocation in promoting education for women in India, for instance, or campaigning to raise the minimum age for marriage. ${ }^{312}$ Barbara Ramusack has called these women "cultural missionaries" and "maternal imperialists". According to her, these women worked as "secular missionaries for Western cultural forms", as these women could never really separate from their Victorian backgrounds and ideals, which they then brought to their educational aims in India. "Maternal imperialism" meant that Indian women were seen as inferior, as victims to be saved from unwanted destinies and to be lifted by means of education to a superior level. 313

The rights of women were not really at the forefront, and are not discussed (at least not at length) in most of the histories of the Mandates system. In the Permanent Mandates Commission, the question was most actively upheld by Valentine Dannevig, the only woman taking part in the discussions. The range of topics, or "social problems", regarding women discussed before the PMC was vast. The questions reached from native customs including the payment of dowries, female circumcision and initiation ceremonies, to child marriages, polygamy, prostitution, female labour and the education of girls. These questions were considered by the Permanent Mandates Commission as social issues, problematic, but open to gradual solutions. According to the Commission, these solutions would come closer as European civilization spread and set an appropriate example. ${ }^{314}$

The Permanent Mandates Commission shared the need to eradicate initiation ceremonies involving female circumcision. Dannevig was particularly vocal in matters relating to initiation ceremonies: "it had not yet been possible to introduce improvements in the initiation ceremonies for young girls complained of by native women when improvements had already been adopted for those of the boys." She stressed the "necessity of giving native women the training and instruments necessary to alleviate the sufferings of the girls until these initiation ceremonies, which evidently conflicted with European ideas of morality, could be entirely

\footnotetext{
310 Ibid., 222.

311 Ibid., 238.

312 See Ramusack, 'Cultural Missionaries, Maternal Imperialists, Feminist Allies: British Women Activists in India, 1865-1945'.

313 Riedi, 'Women, Gender, and the Promotion of Empire: The Victoria League, 19011914 ', 571.

${ }^{314}$ See e.g. Minutes 30 (1936), 62.
} 
abolished as soon as possible". 315 The Tanganyikan representative, Mr. Jardine, was questioned about initiation ceremonies. "The accredited representative took the opportunity of supplying the Commission with information concerning the native initiation ceremonies involving feminine circumcision. He assured the Commission that the Government was making every effort to cause such practices to cease as soon as possible." 316

The prohibition of child marriage was approached through the issue of consent. The Cameroons, for example, gave a decree in 1922 under which no marriage was valid without the consent of the woman. In the administration's view, the decree "was hoped to bring about a gradual evolution of the native mentality". ${ }^{317}$ Should, moreover, there to be a minimum age for marriage? Child marriages were practised by "some of the most backward of all the peoples in the territory, and the customs referred to were unknown among the other natives of South Africa". ${ }^{318}$ However, the PMC was unwilling to draft a minimum age, as the matter was "of an extremely delicate character" and "the Commission could do no more than make a slight study of it". The administration of British Togoland noted a distinction between early marriages and child marriages, as "in such latitudes, the ages mentioned [girls sixteen, men eighteen] were fairly advanced". ${ }^{319}$ From the physiological point of view the PMC found twelve to be the usual minimum age for marriage. They noted that the people criticizing this low age often forgot that "colonial problems were different from European problems". The PMC had been approached on the matter of early marriages by the International Alliance of Women for Suffrage and Equal Citizenship. United, the PMC came to the conclusion that they should "acknowledge the receipt of the letter" and that the attention of the Commission had been drawn to it. 320

On the other hand, the issue of polygamy was not so clearly a matter of protection, although Dannevig wondered if the men had several wives in order to have more free labour at their disposal.321 In fact, the British Cameroons administration did not want to interfere in polygamy: "It selected its officials on their merits and had not up to the present noticed the fact that any official happened to be polygamous in any way affected his capacity for work or his honesty." 322 In the French Cameroons it was reported that "Polygamy was dying out under the influence of Christianity".323 As the Belgian member of the Mandates Committee, Orts explained: "There was a general opinion that

\footnotetext{
315 Minutes 37 (1939), 26.

316 Minutes 18 (1925), 35.

317 Minutes 24 (1933), 43.

318 Minutes 22 (1932), 34.

319 Minutes 16 (1929), 102.

320 Minutes 15 (1929), 221.

321 Minutes 26 (1934), 25.

322 Minutes 24 (1933), 43.

323 Minutes 37 (1939), 108.
} 
polygamy should be discouraged." He did not, however, "believe in the efficacy of fiscal methods [as had been suggested]. The gradual disappearance of polygamy must be expected, above all, from an improvement in morals." 324 Marchand, the French Cameroons representative, complained that " $[\mathrm{e}] \mathrm{ach}$ time that a frontal attack was made on polygamy, failure had been the result. The sole outcome of the efforts made was that the institution it was desired to suppress, the evil it was proposed to root out, took on another form." ${ }_{325}$ He reminded Dannevig that the mandatory needed to respect the native customs as long as they were not contrary to morality. He found polygamy "unfortunate", but was sure that time would change that. ${ }^{326}$ However, in Iraq polygamy was "regarded as old-fashioned and looked down upon". Some polygamy existed amongst the nomads but not in the cities, according to the representatives of the mandatory. 327

There was a close tie between the situation of women and the abolition of slavery. ${ }^{328}$ Drawing a line between marriage and slavery was a question of interest for both Lugard and Dannevig. In The Dual Mandate Lugard explains the complexities concerning the rights claimed over the person of a woman and the difficulties of differentiating between marriage, concubinage and slavery. Concubinage was regulated by Muslim law (e.g. in Nigeria) and had different rules for different groups of women. Moreover, it was difficult to distinguish between dowries, presents, ransoms and the purchase price of a slave. ${ }^{329}$

Lugard was worried about the more hidden ways of slavery, e.g. towards women. He asked the French representative of the Cameroons about the possibility of a dowry constituting in some cases a purchase price for women. Dûchene, the representative, was unable to reply, but realized that progress had been made. ${ }^{330}$ However, the other members of the PMC believed that this was a case where local customs were to be respected. D'Andrade noted that the practice was common everywhere in Africa. Orts doubted whether it would be possible to put an end to a custom "which had lasted for many hundreds of years". Lugard, however, was adamant: "if the dowry constituted in fact the purchase price of a woman, the Administration should put an end to this custom, even if it were immemorial." Despite Orts's hesitancy, he believed that it was possible to make a distinction between an actual dowry and a purchase price,331 whereas Lugard believed that women in Tanganyika were held in a "state of practical slavery". Jardine, the Tanganyikan representative, argued that the situation was quite the opposite. Women in Tanganyika would rather need more restrictions, as they now

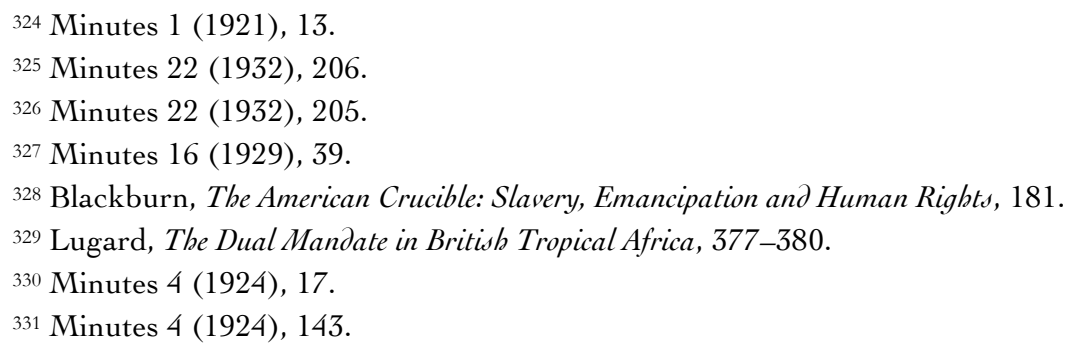


enjoyed a great deal of freedom. He backed this with their possibilities regarding divorce, their position in polygamous households, the opportunities they had to benefit from the results of their farming, and so on. ${ }^{332}$ Dannevig was also interested on the border between marriage and slavery. She had learned that in the Cameroons women became part of the inheritance of the husbands, and thus, after the husband passed away, became the property of the heirs. She noted that no matter how the factual situation of slavery had come about, it could not be tolerated by the mandate. ${ }^{333}$ Orts found it probable that such a "curious custom" existed to ensure the maintenance of the widow. ${ }^{334}$ Dannevig also questioned the administration of British Togoland whether women were regarded as chattels by their husbands. "Both sexes are happy and contented" was the reply that she had to be satisfied with. ${ }^{335}$

While the mistreatment of women could be explained and legitimized by local custom, it was also a useful ground to demonstrate the barbarism and low state of development of the natives. In South Africa the authorities were ready to accept a customary code who would place women as minors in patriarchal village societies, while at the same time declaring polygamy to be female slavery. ${ }^{336}$ Natal's governor Pine bemoaned the fact that the wealthy natives' riches were not the result of honest work but "flowed in fact from polygamy and female slavery". 337

The situation of women, clearly not the most important issue for the generation of men that acted in the administration of the mandated territories, was easy to brush away by referring to the customary character of their treatment. The improvements that had taken place were assumed to be the result of either the spread of Christianity or the influence of European civilization. The representative of Ruanda-Urundi mentioned that "Contact with Christian ideas had improved their [the women in Ruanda-Urundi] position still further." 338

Even though women's rights and gender equality were by no means self evident at the time when the Mandates Commission operated, within the Commission it would appears that feminism and colonialism had found a common cause in moral imperialism. The issues of women's rights that were dealt with by the Mandates Commission were little different than those that European colonial administrations grappled with at the same time. The response to the unpalatable native customs was equally one favoured by colonial administrations: moral concern, optimism for progress and only cautious intervention. Things like female circumcision were soundly condemned and local representatives were instructed

\footnotetext{
332 Minutes 18 (1930), 21.

333 Minutes 22 (1932), 205 and 213.

334 Minutes 22 (1932), 206.

335 Minutes 21 (1931), 45.

336 Mamdani, Citizen and Subject: Contemporary Africa and the Legacy of Late Colonialism, 17.

337 Ibid., 19.

338 Minutes 22 (1932), 236.
} 
to deal with the matter. More problematic was the resurgence of the old colonialist conviction that polygamy especially in combination with the giving of a dowry was equal to slavery. As in many other issues, in the case of women's rights the limits of the power of the PMC were easily seen. They relied on reports by rapporteurs and the assurances of the mandatory administrations that something was being done. Like in many of the other issues in women's rights the widely held belief of the Commission was that the advance of civilization and progress would do more to alleviate the issues than orders issued by the PMC.

Karen Knop has differentiated freedom of religion and the prohibition of abuses (such as slave trade) provided for in the Covenant of the League of Nations from women's rights, maintaining that the first-mentioned were "the only references to human rights in Covenant Article 22", while the inclusion of fundamental freedoms for everyone in the trusteeship system brought new opportunities for women to promote equality in the trusteeship system. ${ }^{339}$ While it is true that the new language of human rights also changed the language in petitions regarding women's issues, in practice the questions relating to women under discussion were the same during the mandates and the trusteeship period. To concrete questions, the reactions continued to be practical and managerial. It was believed that the improvement of the position of women would come with the spread of Western thought and ideas. ${ }^{340}$ Knop maintains that the trusteeships brought an opportunity for women's organizations to promote women's issues in a way that had not been possible earlier. However, many of the organizations acted during the mandates period in similar ways, regardless of the fact that there was no legal basis for this in official documents.

\subsection{Conclusions}

When studying the various themes in the documents of the PMC it becomes apparent that there were great contradictions in the motives behind, and the approach to, the mandates system. There was the conflict between the domestic needs of the mandatories and their unwillingness to give up colonial territory, and the influence of humanitarian ideals. For the League of Nations, the mandates were an experiment in internationalism. It was clear that there would be tensions. The Mandates Commission had to constantly balance between utilitarianism and philanthropy. Especially the labour conditions introduced a debate on the role of natives as an asset into the administration.

The ultimate goal of the mandates was to "stand alone under the strenuous conditions of the modern world". The aim of the Mandates Commission was to educate and to civilize, but it often appeared to lack the belief that some peoples actually could be civilized. One of the aims of education was to teach the "natives" to be useful in their own communities. However, a willingness to improve their

339 Knop, Diversity and Self-Determination in International Law, 332-333.

${ }^{340}$ Ibid., 337. 
position too much through education was disapproved of. It was not proper for the economic or political ambition of the "natives" to approach that of the European. The mandates were an answer to both a political need and humanitarian ideals. The language used derived from the colonial period and remained similar throughout the entire period of the mandates. Lord Lugard has called the contradiction between political needs and humanitarian ideals the dual mandate, ${ }^{341}$ which means that at the same time the interests of the natives were protected and they were given the benefits of civilization, but also the commercial interests of the mandatories were taken care of. There was naturally a tension between these two perspectives. The great contradiction was that the well-meant aim to educate and civilize could be seen as colonialism in itself. This tension can be strongly seen in the discussions between the Mandates Commission and South Africa on the use of the labour of natives in South West Africa.

The Americans strongly believed that new colonies were no longer needed. This, however, is not always evident in the discussion of the Mandates Commission. The Commission certainly did oppose the thought of annexing the territories to those of the mandatories, but the administrators were treated as the real holders of power, if not sovereign rulers. Therefore, it was not always apparent that particularly the $\mathrm{B}$ and $\mathrm{C}$ mandates were governed internationally. The Mandates Commission believed that these territories would become independent only after a very long time, if ever. In theory, the right of nations to self-determination was acknowledged: “...[T]his mission is not, in principle, intended to be prolonged indefinitely, but only until the peoples under tutelage are capable of managing their own affairs." ${ }^{342}$ The acknowledgement lacked concreteness, because "the principle of self-determination could scarcely be applied automatically to peoples which had not yet attained an adequate degree of political maturity, and still less to populations devoid of any real national consciousness". ${ }^{343}$ Nevertheless, the father of the system, General Smuts, regarded the German colonies as "inhabited by barbarians who not only cannot possibly govern themselves, but to whom it would be impracticable to apply any ideas of political self-determination in the European sense...". ${ }^{344}$ The term self government in Article 22 could mean progress towards full sovereignty but did not necessarily mean this.

It was common in the discussions on the different issues to find the cause of problems relating to the inhabitant's rights to be the supposedly low level of civilization in these territories. The PMC rarely saw fault in the conduct of the different administrations, but readily accepted the administrations' reassurances that time, civilization and Christianity would solve the problems that possibly

\footnotetext{
${ }^{341}$ See Lugard, The Dual Mandate in British Tropical Africa.

342 League of Nations, The Mandates System: Origin, Principles, Application.

343 Ibid., 14.

${ }^{344}$ Smuts, The League of Nations: A Practical Suggestion, 15.
} 
existed. The PMC's attitude towards South Africa was an exception, as the PMC continuously criticized South Africa for the poor treatment of the native inhabitants of South West Africa. Thus, South Africa was the given task of guiding the natives to act in their own best interests. But what this interest was, was entirely for the administrations and the PMC to determine. This is most evident in the aim to balance between the preservation of native cultures and to modernize the mandates. The task given by Article 22 of the Covenant of the League of Nations to form a "sacred trust of civilization" for the "well-being and development of such peoples" was in most cases interpreted to mean the modernization and economic improvement of the territory. The position of the native inhabitants was believed to improve as the economic wealth of the territories would improve. Similarly, the spread of Christianity was thought to improve the moral status of the natives. Local customs that were found repulsive by the European administrators were to become history through the spread of Christianity and the Western values that Christianity brought with it.

Thus, the inhabitants were not seen as active members of society and were not believed to be capable of making decisions regarding their own lives. As they were viewed as perpetual minors, their "welfare" was to be determined by those who had been given the task to act as their guardians. Moreover, with the exception of Iraq, both the administration and the PMC discouraged any signs of political initiative from the mandates. Susan Pedersen has shown how in both Syria and Samoa local nationalist movements were repressed. ${ }^{345}$ The French feared Syrian nationalism and with the help of the PMC ensured that Iraq was the only mandate to gain independence before the war. ${ }^{346}$ The Samoans did not understand their own best interests, the administration convinced the PMC. The entire movement that in reality was supported by a large number of Samoans was described to be caused by a few quarrelsome malcontents who had managed to convince the childish Samoans to support them. According to the administration, there was no true understanding by the Samoans of such a cause. They were simply misled by a charismatic individual and failed to realize their own best interest, i.e. mandatory administration.

The belief was that the position of the individual would improve by itself as civilization would spread to the territories. This way of thinking liberated the PMC from taking into consideration the position and hardships of individuals, which they often encountered due to the petitions system. Rather, the PMC supported the administrations' idea of a gradual and automatic change that would be the result of the spreading of civilization and Christianity and the passing of time.

However, the PMC found it difficult to decide what it could expect of the territories as time passed. It was clear that as regards the $\mathrm{B}$ and $\mathrm{C}$ mandates it did

\footnotetext{
345 Pedersen, The Guardians, 191.

346 Ibid., 167-68.
} 
not expect much to happen in a few years or even decades. Also, it was unclear how the different mandates should develop. Should they become societies whose inhabitants would resemble Europeans, or should they develop into new types of societies, unseen before, inhabited by "good Africans"? Penha Garcia worried that in the urban areas, the "European centres", the rapid change caused by the influence of the white population was perhaps not always for the better. Frederick Van Asbeck, who took Van Rees's place as a representative in the PMC follower in the PMC, confirmed that "the greatest difficulties seemed ... to lie with the educated and advanced native". ${ }^{347}$

In the advancement of the indigenous population, all achievement was measured against European standards. Yet the Commission did not want the local populations to resemble Europeans. According to Lugard, "the future of the Europeanized African, and the part he should play in the future of tropical Africa, was perhaps the most difficult problem which confronted the European governments". ${ }^{348}$ Instead, the Mandates Commission used the notion of a "good African". The good African was someone who did not try to imitate the Europeans but was able to gain knowledge from European civilization and turn that into an African way of being and working for the advancement of the African community. In fact, the mandatories were often criticized for trying to develop the natives in the direction of European civilization. One reason for this could be that it was believed that the European civilization was too high a goal for the natives and for that reason they should be left with the second best option, that is, to become at least good Africans. According to members of the Commission, a good African was someone who resembled the Europeans but was not a caricature of them. $\mathrm{He}$ was not Westernized. A good African was not "a half educated African who considered himself quite as good as, if not better than, the white man who governed him." He would make use of the best of Western civilization but would keep his African traditions and ways of thought. ${ }^{349}$

In the end, rather than being granted individual rights, the inhabitants were treated in a paternalistic manner. There were, however, different degrees of paternalism. The most benevolent perspective was represented by the Norwegian Dannevig. Her speech highlighted in a concrete manner the contradiction between belief in the development of the peoples and paternalism. As a believer in education, she expected patience from the mandatories and reminded them that teaching self-governance required the ability to wait until the next generation had been educated. She would thank the representative of a mandatory that his Government's report gave the impression that the administration was striving to understand the natives and treated them "like the children they were, finding in

\footnotetext{
347 Minutes 33 (1937), 113.

348 Minutes 24 (1933), 37

349 Minutes 9 (1926), 137, 140.
} 
them lovable, as well as barbarous qualities." ${ }_{500}$ The British representative Lugard also balanced between utilitarianism and philanthropy. He believed less in the development of the natives but was more pragmatic. His relationship with the inhabitants was mainly based on the indirect model of administration used by the British colonialists. Indirect administration meant that the natives were given responsibilities in their own matters. He talked of independence as a theoretical, at best a very distant, possibility. However, when taking the Mandate, he believed the administrators had accepted the duty to aim towards the independence of the territories. ${ }^{351}$ Lugard also believed in the wisdom of the administrator. The authority of the administrator could not be lost, and thus there was a clear hierarchy between the governor and the governed. D'Andrade, the Portuguese representative, on the other hand, did not hide his view that he did not believe in philanthropy or in the development of the natives and their possibility of becoming independent. He said that this aim would never be reached, if the administrator for philanthropical reasons left "the natives to drink and to indulge in endless debates and inactivity under the pretext that they were happier in this mode of life and that it must be respected". 352 In his view he aimed for the equality of the administration and the native. He believed that this equality would be achieved if the native was assimilated with the governing class. If the natives kept their own organizations, they would always be inferior. 353

The mandates were not a human rights institution and human rights did not belong to the institutional language of the time. However, through the various mandates instruments, Article 22 of the Covenant, the individual mandates agreements, the questionnaires, the petitions and the questioning of the mandatories, certain matters came under public discussion that had not been under institutional scrutiny before. These issues, the position of slaves, workers, women, religious freedom and land rights, would in a few decades be discussed under the rubric of "human rights". The institutional change was fast and in the 1940s a new vocabulary of human rights was developed. However, in practice the change was more gradual. For instance, as Karen Knop has shown, in the trusteeship system the rights of women and petitions concerning them were discussed in a similar manner as in the mandates. Also in the post World War II years it was believed that the position of women would improve once civilization would take over. It was still claimed that changes would happen by themselves, as time passed. Similarly, threats to individual rights would still be externalized and would happen elsewhere, be it due to lack of civilization, fascism or communism.

\footnotetext{
350 Minutes 28 (1935), 76.

351 Minutes 7 (1925), 196.

352 Minutes 6 (1925), 50.

353 Minutes 7 (1925), Annex 12, The Interpretation of that part of Article 22 of the Covenant which Relates to the Well-Being and Development of the Peoples of Mandated Territories, Note by Freire D’Andrade.
} 


\section{Procedures}

\subsection{Introduction}

In the following chapter I study the two processes that made the mandates system different from a traditional colonial governance. Firstly, at least in theory, the mandates were not perpetual. Even when it was widely doubted whether the $\mathrm{B}$ and $\mathrm{C}$ mandates would ever gain independence, there was a certain conditionality in the mandates: they were territories not yet able to stand by themselves under the strenuous conditions of the modern world. ${ }^{1}$ The temporary nature of the A mandates was explicit: "Certain communities formerly belonging to the Turkish Empire have reached a stage of development where their existence as independent nations can be provisionally recognized subject to the rendering of administrative advice and assistance by a Mandatory until such time as they are able to stand alone." ${ }^{2}$ Through the process of independence of Iraq, the PMC was forced to determine what the conditions for the cessation of a mandate and granting independence to a former mandate would be.

Secondly, the petitions provided a channel through which the inhabitants could express their grievances to a body that did not directly govern them. Subjects were also able to appeal in the British colonial system, but the petitions went to the same administration that was also governing them. Despite the PMC's reluctance to criticize the mandates, the mandates system brought a more neutral route for expressing grievances even when the petitions process included forwarding the petitions to the mandatory administration first.

It was not a coincidence that both processes were initiated by the British, and they were in line with Britain's unwillingness to expand their colonial possessions.

Iraq was the only mandate to become independent during the mandates period. The independence process brought concreteness to some of the themes that have been dealt with in the previous chapter. How were the PMC and the mandatory to ensure that the different guarantees given to the inhabitants, and in Iraq, especially the minorities, would continue to be in place? Would an independent Iraq respect the guarantees without outside supervision? Could the same be demanded of Iraq (and other former mandates) than of other states? Was the aim to include Iraq amongst the "civilized states" or rather, merely to get rid of an unwilling mandate? If Iraq was considered less civilized, would there be any ways to continue to assist and supervise it outside the mandatory regime? In addition to the guarantees, the PMC also discussed whether Iraq would adhere to international treaties and whether it would become a member of the League of Nations. The central problem of a very cautious, doubtful and paternalistic PMC

\footnotetext{
1 Emphasis mine.

2 The Covenant of the League of Nations (1919), Article 22.
} 
was whether Iraq was a state comparable to other independent (Western) states, or whether there were other criteria for statehood that could apply in the case of Iraq, with a limited sovereignty and continuing supervision.

Also the gradual development of the petitioning system centred on the questions of whether a civilized state and its administration could be supervised. In order not to control the mandatory states too much, the PMC constantly balanced and limited its own supervisory powers, insisting that it did not want to be a court of appeals. Rather, the PMC saw the petitions mainly as a tool to gather information from the mandates. There was no mention of the petitions in Article 22 of the Covenant or the individual mandates, but the entire system would develop when the mandates system was in operation. There was a continuing discussion on what the petitions were and how they should be treated and used. As new questions and demands were raised in individual petitions, the PMC was forced to continuously develop the petition procedures. The number of received petitions was vast, and therefore the PMC had a large amount of material from the mandates and different interest groups to deal with. The contents and approach of the petitions varied. Many of them should have been dealt with in the courts, others were more general demands for fairness, and many also included a demand for political self-determination.

\subsection{Protection of Minorities and other Obligations of Newly- Independent Territories}

"This capacity of self-government is explained by the continuation of the sentence 'under the strenuous conditions of the modern world'.

This means that the capacity of self-government must be able to exert itself smoothly under the present political, economic, commercial and other conditions of the modern world. It is not only the system of government, the stage of development of the population, the economic equipment, the guarantees of individual rights, the administration of justice or administrative ability which indicate the existence of this capacity. ... It is the sacred right of those really capable of governing themselves." 3

While reading the minutes of the PMC it is often easy to forget that the ultimate aim of the mandates system was to guide the mandated areas towards independence. The debates about the $\mathrm{B}$ and $\mathrm{C}$ mandates were so strongly coloured by colonial discourse that the idea of independence was almost never uttered. In the case of Iraq the issue arose quickly, leading the PMC to confront what kind of preconditions should a state meet not only to gain independence but also to be admitted to the League itself. The aim of this section is to examine this issue through the concern for the protection of religious and ethnic minorities in Iraq. As we shall see, the United Kingdom aimed for a swift exit from its obligations in

\footnotetext{
${ }^{3}$ Report by Count de Penha Garcia, Minutes 20 (1931), 206.
} 
Iraq and members of the PMC were deeply sceptical of the competence of the Iraqi administration. A system of petitions about the rights of the minorities was on the agenda but the underlying problem was what kind of attitude should the PMC adopt. Due to the limited powers of the PMC, suggestions concerning strict conditions for independence and an active role for the PMC were met with scepticism, as were the plans to institute a comprehensive system of petitions.

Iraq had become a burden for Britain and in Britain there was strong support for Iraq's independence. Britain's initiative on the independence of Iraq surprised the League of Nations and other mandatory states. It had been believed that the independence of the A mandates could be realistic only in the very distant future. No concrete plans for the independence of any of the mandates existed and in Syria all nationalist movement had been suppressed.

Iraq was becoming expensive for Britain and Britain had planned to draft a bilateral treaty already before the establishment of the mandates with the Iraqi government, which was loyal to her. To the disappointment of Iraq, a mandate was however established, but this was done in the form of a bilateral treaty instead of the normal mandates agreement. The treaty acknowledged the sovereignty of the state of Iraq and gave Britain the task of giving advice and assistance. ${ }^{4}$ More specifically, Britain was to assist Iraq e.g. "on all important matters affecting the international and financial obligations and interests of His Britannic Majesty" (Art.4) and provide assistance and support to the armed forces of Iraq (Art. 7). Britain also agreed to further Iraqi membership in the League of Nations "as soon as possible" (Art. 6).

To the dissatisfaction of Iraq, the independence plan started to proceed only at the very end of the 1920s, when Britain received a new Labour government. The new government started to plan independence for Iraq for 1932.

Independence would not weaken Britain's position in Iraq, quite the contrary. Britain still was responsible for the defence of Iraq and would have economic advantages as well, only without international supervision. However, the other mandatory states were also interested in Iraqi oil. Invoking the open door policy, the other mandatory states made sure that Britain could not control Iraqi oil on its own. The Iraqis themselves were to have little say on the distribution of their own oil. ${ }^{5}$

The British interpretation of the criteria set by Article 22 of the League of Nations for granting independence to mandated territories was that "a state should be fully self-governing, should be able to stand alone and should be such as

\footnotetext{
4 "At the request of His Majesty the King of Iraq, His Britannic Majesty undertakes [...] to provide the State of Iraq with such advice and assistance as may be required during the period of the present Treaty without prejudice to her national sovereignty." i, L.N. Doc C.717 M.429. 1922.VI, 3 League of Nations Official Journal (1922), 1505. See also Pedersen, The Guardians, 262-63.

5 Ibid., 270-76; Dodge, 'International Obligation, Domestic Pressure and Colonial Nationalism: The Birth of the Iraqi State Under the Mandate System’, 152-55.
} 
could be relied upon to observe its international engagements". ${ }^{6}$ Thus, according to the British, not only one correct model for an independent state existed, and the League Covenant did not demand that there be an especially high-level cultural and political development. In the British view, the idea of the League of Nations was to be as inclusive as possible to new states, not exclusive. Rather, the membership of a state in the League of Nations would set an example to "backward States" and support an independent state to achieve an even higher level of civilization. 7 . Moreover, the British government had stated that Iraq had actually had the machinery of a civilized government, and thus it could be concluded that it was capable of self government. ${ }^{8}$

Of the other nations represented in the PMC, Germany was generally open to the idea of Iraq as an independent state. Germany had calculated that it would gain from a friendly relationship with an independent Iraq in terms of economic concessions. For this reason it was important for Germany that the terms of the independence ensured that Britain's position in the future Iraq was not too strong. ${ }^{9}$ France's stance shifted from the initial bewilderment to admiration at the ingeniousness of the British plan. The French had an interest in Iraqi oil and succeeded in securing a pipeline to the Mediterranean to be routed through Syria. ${ }^{10}$ Thus, in the end the French, contrary to their initial resentment, started to see Iraq as a model for the future Syria as well. ${ }^{11}$

The permanent mandates commission, however, was not convinced by the British views. First of all, the PMC was not satisfied with the way that Britain was fulfilling its duties as the mandatory. According to Rappard, Britain was acting merely as a diplomatic observer, and not actively fulfilling its role. $\mathrm{He}$ reminded the British that there was a number of obligations that the British needed to take care of, including the minorities in Iraq. ${ }^{12}$ Therefore, the PMC would continue to question Britain on the advancement of Iraq, not only on the positions of minorities, but also on other guarantees such as legal matters relating to foreigners, religious freedom and economic equality. ${ }^{13}$ The PMC wished to reassure that there was no issue of principle in them opposing the independence of Iraq. Iraq was welcome as a member of the League of Nations if and when certain conditions were fulfilled, such as Iraq's ability to stand alone, and assurances of Iraq's willingness to observe its treaty obligations towards its minorities as well as towards member states of the League of Nations.

\footnotetext{
${ }^{6}$ Minutes 20 (1931), 124.

7 Minutes 20 (1931), 124.

8 Minutes 20 (1931), 134.

9 Pedersen, The Guardians, 269-70.

${ }^{10}$ Ibid., 274.

11 Ibid., 276-77.

${ }^{12}$ Minutes 19 (1930), 96.

${ }^{13}$ Minutes 19 (1930), 174.
} 
At this point the PMC did not believe that Iraq was willing to take similar binding guarantees towards its minorities as, for instance, Albania had done. ${ }^{14}$ Iraq's population was comprised of several minority groups, many of which also had nationalist aims. The largest group was the Shia Arabs, followed by Sunni Arabs and Kurds. Other religious groups included Jews, Yezidis, Bahais and various Christian groups, of which the PMC was most concerned about the Assyrians. The Kurds had nationalist aspirations which, however, received no support either from the Iraqi government, the British or the PMC. The PMC, however, maintained that the Kurds had a minority position, and that their rights as a minority needed to be taken care of. Even more, the PMC was uneasy about the Assyrians, who were Christian and had been allies of the British during the war. ${ }^{15}$ Admittedly, the minorities were the most difficult issue in Iraq's independence. Susan Pedersen argues that the birth of Iraq helped to create the minorities as a category not only in Iraq but in general as well. ${ }^{16}$ Orts noted that "[o]ne of the reasons why Iraq was refused complete independence was that it was not yet considered to possess that spirit of tolerance which made it possible to place in its charge, without any apprehension, the fate of the racial and religious minorities established in the territories accorded to the country." ${ }^{17}$ Orts blatantly noted that the whole question of independence would be easier if there weren't minorities in Iraq: "[T]olerance had not always been a dominant virtue of these Levantine peoples." 18 Rappard objected to the High Commissioner for Iraq, Sir Francis Humphrys' optimism and believed that the Assyrian minority had come to Iraq to expect protection from the British government. ${ }^{19}$ Dannevig also noted that she was opposed to Iraqi independence as she felt that it would weaken the position of women and children, which according to her had benefited a great deal from the British influence. ${ }^{20}$ Orts concluded: "[T]he discussion had shown that, in any case, the members of the Commission appear to have very little confidence as to the way in which the Iraqi Government would treat the minorities." ${ }^{21}$

There were concrete signs that the suspicion of the PMC was perhaps justified. The PMC believed that Iraq's independence would pose an actual threat to different minorities in Iraq. Orts noted that the different minorities, regardless of their religion, language and race were anxious because of the planned independence and they were concerned for their future. In Orts's view, the fact that they considered themselves to be under threat meant that there were true

\footnotetext{
14 Minutes 19 (1930), 96.

15 Pedersen, The Guardiand, 277-80.

16 Ibid., 277.

17 Minutes 20 (1931), 134.

18 Minutes 21 (1931), 58.

${ }_{19}$ Minutes 20 (1931), 135.

20 Minutes 21 (1931), 58.

21 Minutes 21 (1931), 68.
} 
reasons to be concerned about the upcoming independence. ${ }^{22}$ The PMC received petitions from various minority groups, and contrary to petitions from other territories, these asked for the continuation of the mandate rather than its end. Others feared "disfavour and reprisals" if they would complain about their treatment to the PMC. ${ }^{23}$ In Rappard's view, "it seemed ... that the attitude of the Kurds was not so entirely unreasonable as might at first sight appear". ${ }^{24}$ Also the Assyrians and the Bahais had concrete reasons to fear for their future. ${ }^{25}$

For example, a petition dated July 26, 1930 by a group of Iraqi Kurds asked for the "fulfilment of their national rights which were admitted by the League of Nations". They expressed their fear that the Arab administration would worsen the situation of the Kurds and "will [be] worse than that of Turks if Mandate is ended". ${ }^{26}$ Thus, the petitioners asked for the formation of a Kurdish government under the supervision of the League of Nations. The petitioners claimed that they had been promised self-government when the Iraqi mandate came to an end and that the recent Anglo-Iraqi treaty had forgotten their rights entirely. ${ }^{27}$

In its response to the petition Britain rejected any promises of autonomy to the Kurds as a misconception. The response, written in a very paternalistic tone, all but ridiculed the Kurds for even imagining that they would have been promised any type of self-government. This idea was "probably fostered by elements working for Kurdish independence". ${ }^{28}$ Economically and geographically the British considered such a plan "wholly impracticable", whereas politically it was "almost fantastic". The list of qualities given to the Kurds was long: "they are entirely lacking in those characteristics of political cohesion which are essential to successful self-government, $[\mathrm{t}]$ heir organisation and outlook are essentially tribal, ... their mode of life is primitive, and for the most part they are illiterate and untutored, resentful of authority and lacking in a sense of discipline or responsibility." 29 The British admitted that the Iraqis had not entirely kept their promise to keep Kurds in administrative positions or secure their language rights, but these shortcomings were only understandable because of the "unpromising material" available to fill administrative posts in Kurdish areas and the fact that "until recent years, Kurdish, as a language of written communication was unknown". ${ }^{30}$ However, the British considered that any reason for complaint had now ceased to exist as the situation in the Kurdish areas had now been

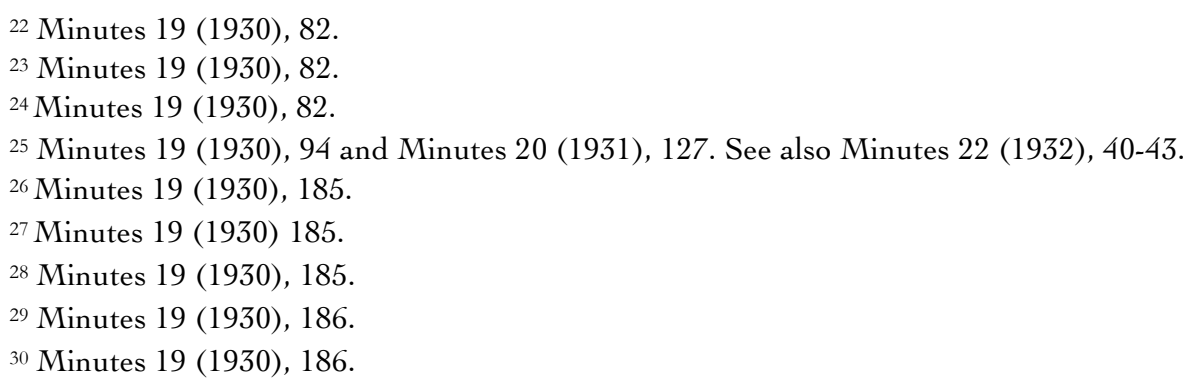


"sympathetically examined" by a new Iraqi government. ${ }^{31}$ Similarly, the Iraqi government gave the assurance that their "friendly and sympathetic policy" ought to satisfy all "reasonably-minded" Kurds. However, if it did not, "liberty of action" would be assumed by Iraq. ${ }^{32}$

Rappard in his report did not hide the fact that he was not convinced by the British and Iraqi assurances. He stated that even with a new language law forthcoming, there would not be sufficient safeguards to which the Kurds had been entitled, including appointments to administration and the use of the Kurdish language in courts and schools. The fact that the mandates were about to come to an end made these shortcomings even more acute. However, the PMC rejected the petition giving Britain only two considerately worded recommendations: firstly, to put promptly into effect the legislative and administrative measures for securing the Kurds the position they are entitled to, and secondly, "to consider the advisability of providing measures" that would maintain the minority position of the Kurds in the event of Iraqi independence. ${ }^{33}$

The recommendations given by the PMC were more determined when it came to a petition by Captain Hormuzd Rassan, representing the various nonMuslim minorities in Iraq. (In his petition he claims to represent the Assyrian, Chaldean, Jacobite, Protestant, Syrian Catholic, Armenian refugee and Yezidi communities). ${ }^{34}$ Like other petitioners, he pointed out that the latest Anglo-Iraqi treaty of 1930 failed to protect non-Muslim minorities in Iraq. ${ }^{35}$ He requested that, as the Iraqi mandate was coming to an end, the League Council set up an Commission of Enquiry to see to what extent the mandatory had set up recommended safeguards for minorities in Iraq. ${ }^{36}$ The British reply to the complaint was that firstly, there was no real dissatisfaction amongst the minorities, but complaints had been deliberately collected. Secondly, they claimed that the petition represented only the Assyrian community, not the other Christian communities. Thirdly, the British either disputed the facts stated in the petition, or undermined their gravity while accepting their accuracy. ${ }^{37}$ The PMC report was written by Orts, who admitted that the different minorities, both Muslim and nonMuslim were apprehended for their future and believed that there might be good reasons for it. While not recommending what the petitioner requested, the PMC

\footnotetext{
${ }_{31}$ Minutes 19 (1930), 186.

32 Ibid.

${ }_{33}$ Minutes 19 (1930), 194.

${ }_{34}$ Minutes 19 (1930), Annex 3. Iraq. Preliminary Question of Procedure Submitted to the Commission in Connection with a Petition Relating to the Position of Non-Moslem Minorities in Iraq, 163; Minutes 20 (1931), 217.

35 See also Minutes 20 (1931), Annex 10, Petitions Emanating: (a) from Kurds of Iraq Transmitted by the British Government on February 20 $0^{\text {th }}$. 1931; (b) from Tawfiq Wahbi Beg, dated April 19 ${ }^{\text {th }}$, 1931. Report by M. Rappard, 221.

36 Ibid., 218.

${ }^{37}$ Ibid., 218-219.
} 
suggested that the League Council should draw the mandatory's attention to three points. Firstly, the mandatory ought not to relax its supervision over the situation of the minorities. Secondly, it was necessary to obtain guarantees from the Iraqi government with regard to the treatment of racial and religious minorities before the mandate ends. Thirdly, the PMC asked the Council to inform the petitioner of the League's continuing support for minority rights, given that the minorities for their part promote the security and goodwill of the Iraqi state. In practice, this meant that help would be provided as long as minorities did not cause trouble. ${ }^{38}$

Also, the PMC and Iraq had differing opinions about what constituted a minority. The Interior Minister of Iraq had noted that the Kurds did not constitute a minority, but rather a separatist group. In Iraq's view, the position of a minority implied subordination whereas the emphasis should be on the unity of Iraq. Rappard was worried that if there was such a difference of opinion in what constituted a minority, there was little hope of cooperation about minority questions after Iraq's independence. ${ }^{39}$

However, the British reassured the PMC that the Iraqi government had every intention of treating their minorities well and would indeed do so. In the British view, the problems that would inevitably occur would be isolated ones and would be rather due to individuals creating conflict and confrontation, rather than acts of the Iraqi government. ${ }^{40}$ Humphrys, the British representative, noted that "as regards tolerance, he night say, realising the heavy responsibility which lay on him, that he could assure the Commission that, in his thirty years' experience of Mohammedan countries, he had never found such tolerance of other races and religions as in Iraq". ${ }^{41}$ Humphrys gave the assurance that everything would go well and the PMC should trust Iraq; the Iraqi government would honour the treaty. ${ }^{42}$ To reassure the PMC, the British representative had told the Commission that it had already informed Iraq that it was likely that guarantees would be required for racial and religious minorities. ${ }^{43}$

The question of the independence of a mandated territory and the guarantees needed to achieve that independence were novel and such guarantees were not stipulated in any of the instruments on the mandates. The PMC believed that in order to find the right guarantees for Iraq, they needed to look into the origins of the mandates regime. Thus, the legal sources on which they would base the guarantees for Iraq were Article 22 of the League of Nations Covenant, the Versailles Peace Treaty and the mandates charters. However, all of these documents lacked concrete guidelines, and thus, there was a need to refer to other,

\footnotetext{
38 Ibid., 219.

${ }^{39}$ Minutes 20 (1931), 126-127. See also Pedersen, The Guardians, 279.

40 Minutes 20 (1931), 123.

41 Minutes 20 (1931), 134.

42 Minutes 20 (1931), 134.

43 Minutes 19 (1930), 88.
} 
unspecified, documents for purposes of interpretation. ${ }^{44}$ In general terms, what the PMC was expecting to find were "[...] obligations assumed towards Members of the League of Nations; Guarantees for freedom of conscience and religious institutions; Guarantees for the protection of minorities of race, language and religion, if any such exist in the territory; Guarantees for an adequate judicial system; Guarantees for safeguarding under the new regime the moral and material interests developed in the territory during the mandates regime ...". ${ }^{45}$

The PMC was aware that while they were now discussing the guarantees for the minorities of Iraq, any mandate that might gain independence in the future would most likely be required similar guarantees. Therefore, the work needed must be done carefully. "These guarantees [for minorities], which must be expressly laid down by law, must be solemnly proclaimed and recognised in the act which terminates the mandate. They must ensure internal peace in order to create that moral unity on which a country's life must be based." 46 Penha Garcia emphasized that as long that there was such moral unity in the territory and the social development of the territory was not to be "in opposition with the general principles of human civilisation", a new state did not necessarily need to have "the form of a European state". However, he required that legislation must grant everyone, nationals and foreigners, "individual rights and guarantees corresponding to the general principles of international law". ${ }^{47}$

The members of the PMC set out to draft a set of reports and declarations concerning the guarantees. ${ }^{48}$

In his report to the League Council on the termination of the Iraqi mandate, Penha Garcia concluded that

(b) It [the League of Nations] would welcome the entry of Iraq into the League of Nations if and when certain conditions are fulfilled;

(c) Of these conditions the principal are: That it should be apparent that Iraq is able to stand alone and that effective guarantees are secured for the observance of all treaty obligations in Iraq, for the benefit of racial and religious minorities and of the States Members of the League of Nations. ${ }^{49}$

Van Rees presented a draft declaration concerning the minorities in Iraq that declared that the guarantees that the League was about to demand from Iraq

\footnotetext{
${ }^{44}$ General Conditions that Must be Fulfilled before the Mandate Regime can be Brought to an End in Respect of a Country Placed under that Regime. Preliminary Report by Count de Penha Garcia. Minutes 19 (1930), Annex 8, 175.

45 Ibid., 176.

${ }^{46}$ Minutes 20 (1931), 208.

47 Ibid., 210.

${ }^{48}$ See Harris Evans, 'The General Principles Governing the Termination of the Mandate'.

${ }^{49}$ Minutes 19 (1930), 174.
} 
would constitute "obligations of international concern, and will be placed under the guarantee of the League of Nations". This would mean that possible violations could e brought to the attention of the League Council by any member state and any legal or factual disagreements between Iraq and any League member would be considered "a dispute of an international character under Article 14 of the Covenant of the League of Nations" and could be brought before the Permanent Court of Justice. ${ }^{50}$

Orts supported the draft declaration adding, however, that eventual changes to the Constitution and Code of Iraq should not affect the position of minorities and that both instruments should be applied in the "right spirit". He also wished to add the right to petition to the minorities, both as individuals and groups. ${ }^{51}$

Merlin, the French representative, thought that the guarantees should remain sufficiently general. He was opposed to the idea of introducing a reference to minorities and majorities, as it "would open the door to insoluble difficulties". ${ }^{52}$ Rather, he would have included "a corpus of laws and a judicial organisation enabling it to render to all elements of the population and to each individual equal justice regularly executed". 53

However, a note on minorities was to be added to the guarantees. Lugard wished to include "the welfare and just treatment of racial, linguistic and religious minorities", and this would be enforced by the right of appeal to the Minorities Committee of the League of Nations Council. In Lugard's view, the protection of minorities would not be efficient without the right of petition, either to the League Minorities Committee or to the Permanent Court of International Justice. ${ }^{54}$

What is noteworthy is that the PMC was not familiar with the details of the minority system in the League. The League had the complete machinery including a series of treaties for the protection of different minorities in Europe and a Commission to act as a supervisor. As the PMC realized that experiences from earlier minority treaties would be useful to take into account when drafting a treaty for Iraq, they invited Pablo de Azcarate, the head of the League minority section, to explain the system. Azcarate noted that the document drafted by Van Rees was an exact copy of the guarantee clauses of the minority treaties. ${ }^{55}$

In addition to, but also of course relating to, minority rights, the guarantees were also meant to ensure "freedom of conscience and public worship and the free exercise of the religious, educational and medical activities of missions of all denominations subject to such measures as are indispensable for the maintenance of public order and morality, and good government". ${ }^{56}$ The PMC held a discussion

\footnotetext{
${ }^{50}$ Minutes 21 (1931), 66.

51 Minutes 21 (1931), 66.

52 Minutes 20 (1931), 153.

53 Minutes 20 (1931), 153.

${ }^{54}$ Minutes 21 (1931), 64.

55 Minutes 21 (1931), 64-65.

${ }^{56}$ Minutes 20 (1931), 182.
} 
on whether the limitations to religious freedom concerning morality could apply to freedom of conscience per se, or only to the working of missions. Lugard was worried about the consequences of such limitations to non-Muslim minorities in a Muslim country. Would the concept of public morality give too much leeway to the Iraqi government to restrict the actions of, for instance, the Bahai minority? Orts believed that there was a need for such a limitation as the state should in the last resort be able to control the missions in its territory. Thus, the limitation was accepted with the understanding that it applied only to the possibility of limiting education given by the missions. ${ }^{57} \mathrm{~A}$ similar clause existed in all mandatory statutes. In the case of Iraq, the PMC was for the first time confronted with the situation where the concept of public morality would derive from a non-Christian, i.e. a Muslim, worldview. Thus, a clause that existed unquestioned in all mandates was now seen as a possible risk to the existence of Christian minorities in Iraq.

The members of the PMC disagreed on whether they could demand that Iraq became a member in international conventions. ${ }^{58}$ Lugard noted the need to demand that the newly independent state would accept international legal obligations, such as the conventions prohibiting slave trade and the traffic in women and children.59 Van Rees concluded that they could not speak of conventions in general terms. There were certain conventions that had been signed by the mandatories on behalf of the territories, as had been requested in the individual statutes of the mandates. These would remain in force in the territories even after independence unless the new states denounced them. Such conventions included the slavery conventions, the convention on the trafficking of women and children, and the conventions on trafficking arms and drugs. ${ }^{60}$ On the other hand, "conventions providing for the extension of the benefits of general and special international conventions or treaties" would cease to be in force in the newlyindependent states. ${ }^{61}$

As Iraq was the first mandate to gain independence, it was the task of the PMC to determine all formalities relating to the upcoming emancipation of Iraq. Van Rees was hesitant whether it actually was the duty of the PMC to decide on the formalities. ${ }^{62}$ The Chairman Theodoli concluded that this was so, because the Council had given this task to the PMC. ${ }^{63}$

The different legal options to formulate the guarantees were by declaration or by treaty. Rappard did not find a declaration to be sufficient, ${ }^{64}$ but noted that "the Commission should confine itself to enumerating the guarantees to be furnished

\footnotetext{
${ }^{57}$ Minutes 20 (1931), 182.

58 Minutes 20 (1931), 155.

59 Termination of a Mandate, note by Lord Lugard, Minutes 20 (1931), 202.

60 Minutes 20 (1931), 154.

${ }^{61}$ Minutes 20 (1931), 199.

62 Minutes 21 (1931), 62.

63 Ibid.

${ }^{64}$ Minutes 21 (1931), 64.
} 
by Iraq, and to stating that the act in which those guarantees were embodied should make it possible, if necessary, for any disputes that might arise regarding its interpretation or application to be brought before the Permanent Court of International Justice". ${ }^{65}$ De Penha Garcia also found it necessary for the guarantees to be binding on Iraq. A mere declaration might suffice in the case of Iraq wanting to join the League of Nations, as the League could then set certain guarantees as a precondition for membership, but if Iraq did not want to join the League, a declaration was not enough to make sure that Iraq abided by the guarantees. Van Rees wondered who would be the parties to the treaty if such a binding document was to be chosen. He also noted that no more could be demanded from Iraq than what was already included in the states signatories to the League's minority treaties. Merlin believed that the task at hand was merely to apply the principles formulated by the PMC to the case of Iraq. The task of the PMC was only to turn the League Council's attention to the effective protection of minorities in Iraq. ${ }^{66}$

PMC's trust in Iraq's motivation to take care of its minorities was so weak that it came up with a variety of enforcement safeguards that would ensure the protection of the minorities.

Apart from not being sure whether Iraq would accept a model similar to e.g. Albania, Rappard worried that the Albanian model would not be sufficient to ensure the protection of minorities. In the Albanian model, in the case of a conflict, a member of the League Council would have taken the matter to the Council. However, Rappard feared that Iraq was geographically so distant that in situations of concrete infringement no one would actually react. Therefore, he would have rather seen a system where anyone could have petitioned on behalf of a minority. ${ }^{67}$

Another model was to set up an authority in Iraq, the duty of which was to ensure that Iraq kept to its obligations. Rappard suggested that a representative of the League of Nations would reside in Iraq to supervise the treatment of minorities. Another option, also suggested by Rappard, was to give the task to the British Ambassador. He was, of course, already in the territory and had a special and privileged position there. One could even consider it his duty and it was the least that the British could do for the sake of minority protection. ${ }^{68}$ Penha Garcia and Merlin also supported giving the task to the British Ambassador. In Merlin's view, the Ambassador would act as an advisor to the government of Iraq, and if his suggestions were not followed, the said minority could turn either to the League of Nations or to the British government. ${ }^{69}$ Theodoli feared that if this duty

\footnotetext{
${ }^{65}$ Minutes 21 (1931), 63.

${ }_{66}^{66}$ Minutes 21 (1931), 63.

${ }^{67}$ Minutes 21 (1931), 115.

${ }^{68}$ Minutes 21 (1931), 66.

${ }^{69}$ Minutes 21 (1931), 67.
} 
was given to the British, it would infringe the sovereignty of a foreign state. ${ }^{70}$ Ruppel agreed with Rappard, but as he anticipated that the British government would not agree, he suggested the establishment of a specialized court where three British judges would judge minority questions. Unsatisfied parties could appeal to the League Council.71 Dannevig also supported establishing the Court. ${ }^{72}$ Lugard supported the right to appeal, but appeals should be made to the Minorities Committee of the League Council. He considered that no protection was possible without an effective right to petition and was also open to the idea of giving minorities access to the Permanent Court of International Justice. ${ }^{73}$ But, as Rappard pointed out, the Permanent Court was not open for complaints by nonstate actors.

M. Penha Garcia noted that the League of Nations still had responsibilities after the termination of the mandate. "Mandates are held on behalf of the League of Nations, and it is for the latter to make sure that the benefits and results achieved continue under the régime of full independence." 74

The British administration was opposed to sending a League representative to ensure the rights of minorities, nor anyone else, for that matter. The British representative believed that Iraq would see this as a violation of its sovereignty and a sign of mistrust. Iraq would have signed a treaty on the protection of minorities, and moreover, according to him, Muslims, Christians and Jews had lived in peace in Iraqi territory for centuries. Sending a representative would therefore be a provocative act that would reaffirm existing conflicts and cause new ones. ${ }^{75}$

Iraq was the only state to gain independence during the mandates period and the discussions on the impending independence reveal the PMC's ideas of what an ideal society outside Europe would look like. In Europe the League had demanded certain guarantees from states about to become independent and these guarantees were not dissimilar to those required by Iraq.

The independence process of Iraq demonstrates how rights language was used to distinguish between the modern and the "other", the West and the East. Iraq needed to take into account certain "obligations of a humanitarian nature" in order to prove that it was a "State worthy to take its place among the other nations". In the League's view, these were demands that "the civilised world has a right to make". ${ }^{76}$ Thus, the question was what were the conditions which a non-

\footnotetext{
70 Minutes 21 (1931), 68.

71 Minutes 21 (1931), 67.

72 Minutes 21 (1931), 68.

73 Minutes 21 (1931), 64.

${ }^{74}$ Wright, 'The Proposed Termination of the Iraq Mandate', 445.

75 Minutes 20 (1931), 140.

${ }^{76}$ General Conditions to be Fulfilled before the Mandate Regime Can be Brought to an End in Respect of a Country Placed under that Regime. Note by M. Van Rees, Permanent Mandates Commission, Minutes 20 (1931), 198.
} 
European state needed to fulfil in order to be welcomed as part of the international community. Throughout the process, the PMC was suspicious about Iraq's "worthiness" to act as an independent state. The main reason for the suspicion was a worry about the many (Christian) minorities existing on Iraqi territory.

And in hindsight, after the Iraqi army had initiated an armed attack on the Assyrian minority, the commentators could only note that stricter guarantees should have been in place, as "the respect for life is not as great in the East, however modernized, as it is in Western Europe". ${ }^{77}$ The PMC was left to realize that even with hundreds of Assyrians killed, they had no tools left to assist the distressed people. The mandate had come to an end and the events were not within the competence of the PMC. The PMC, however, did not want to appear ignorant. Could they not raise the question when the final report of the mandatory power was examined? "There was nothing indiscreet in such a question addressed to an ex-mandatory Power which had recommended the admission of Iraq to the League, and had thereby accepted a moral responsibility which outlined the Mandate," Orts insisted. ${ }^{78}$ Rappard agreed, noting that it was the PMC's task to realize its own lack of competence. However, the general public might see the PMC as indifferent, if they only expressed "humanitarian sentiments as long as it was legally permitted to do so". ${ }^{79}$ Only Palacios did not agree: "To make a will, it was necessary to be alive, and the Mandates Commission, so far as Iraq was concerned, had already ceased to exist in October 1932." 80 With hindsight Rappard could note that "[the PMC's] hopes had been disappointed and their fears confirmed. When dealing with other territories subsequently, the Mandates Commission would be bound to remember what had happened in Iraq." ${ }^{11}$

The independence of Iraq prompted by the decision of Great Britain to withdraw from its obligations as an administrator became the first and only test case of raising a mandated territory to a sovereign nation. While this was the underlining aim of the whole mandates system and its justification, the League and the PMC were caught off guard by the plans. Many of the members were sceptical about whether Iraq was truly ready for independence. Distressed signals had reached the PMC from the different minority groups of Iraq, who had feared for the future. This meant that the PMC would in this first test case mostly discuss limits that might be imposed upon the sovereignty of Iraq. A petition system for those religious minorities was demanded with numerous alternatives for the recipient of the petitions. The mandatory itself was strictly opposed to the interference by the PMC as well as to the limits to the sovereignty of the newly-

77 Hales, 'Some Legal Aspects of the Mandate System: Sovereignty - Nationality Termination and Transfer', 117-18.

${ }_{78}$ Minutes 24 (1933), 28.

79 Ibid., 29.

${ }^{80}$ Ibid.

${ }^{81}$ Minutes 24 (1933), 32. 
independent state. The British assured the PMC that all concerns of ethnic strife were overblown and that nothing but the continuation of religious harmony could be expected. They were, as the hindsight of history tragically demonstrates, wrong and innumerable lives were lost in the interethnic and religious conflicts that followed. ${ }^{82}$

\subsection{Petitions}

The system of petitions was a new innovation that was included in the mandates system only after it was founded. Discussions about instituting a system of petitions had taken place when the system was drafted, but its realization was very much a British innovation. The aim of this section is to trace the creation of the system of petitions and especially the debates over the form that it should take. The reason for this is that precisely these forms reveal the motivations behind the petitions as well as the possibilities that the system would have and whose interests the system would serve.

The United Kingdom had a petition system, the right to "petition the crown", since the Middle Ages. This right was possessed by people who were affected by a certain legal norm. For example, in the early $18^{\text {th }}$ century, petitions were used to demand rights to the slave trade, but by the late $18^{\text {th }}$ century the practice had been reversed and petitions were sent to request the abolition of the slave trade. ${ }^{83}$ Eventually the right to petition to the Privy Council had been included in the colonies as well. ${ }^{84}$ According to Duncan Hall, "[i]t had come to be regarded as one of the immemorial and vital safeguards of individual rights and liberties". ${ }^{85}$ Also, inhabitants in other mandates had been accustomed to the possibility of appealing, such as Ottoman subjects, Samoans and the Duala in the Cameroons. ${ }^{86}$

The petitions were an important sign of the flexibility of the mandates system, as they did not originally exist in the covenant, the terms of the mandates, nor the constitution of the Permanent Mandates Commission. ${ }^{87}$ A right to petition did exist in the context of the League minorities treaties. ${ }^{88}$ Originally, there had been plans to include petitions in the mandates. Smuts, for instance, suggested the

\footnotetext{
82 Pedersen, The Guardians, 286.

${ }^{83}$ Blackburn, The American Crucible: Slavery, Emancipation and Human Rights, 166.

${ }^{84}$ Hall, Mandates, Dependencies and Trusteeship, 198; Momirov, 'The Individual Right to Petition in Internationalized Territories: From Progressive Thought to an Abandoned Practice', 217; Pedersen, The Guardians, 82.

${ }^{85}$ Hall, Mandates, Dependencies and Trusteeship, 198.

${ }^{86}$ Pedersen, The Guardians, 78.

${ }^{87}$ Hall, Mandates, Dependencies and Trusteeship, 198; Wright, Mandates Under the League of Nations, 119.

${ }^{88}$ Momirov, 'The Individual Right to Petition in Internationalized Territories: From Progressive Thought to an Abandoned Practice', 215.
} 
right to petition in his plan for the establishment of mandates, ${ }^{89}$ and Wilson in his drafts for the League of Nations Covenant. ${ }^{90}$

Britain was eager to introduce a system of petitions to the mandates following the British model. ${ }^{91}$ The British Government had sent a memorandum suggesting the possibility of receiving petitions from the mandated territories. This memorandum had been drafted by Ormsby-Gore together with the British Colonial office and presented to a reluctant League Council. The League Assembly received the draft more favourably, having by then heard of the bombing of the mandate of South West Africa by its mandatory. ${ }^{92}$ The British initiative on petitions was discussed by the League Assembly in 1922.93

Being pressured by the publicity of the situation in South West Africa, the League Council finally agreed to consider the draft on petitions. ${ }^{94}$ The interests of the mandatory powers were well taken care of by giving them a chance to comment on all petitions. ${ }^{95}$ However, the mandatories were reluctant to accept the idea as they feared it would undermine their prestige in the eyes of the people to whom the Permanent Mandates Commission might appear to be a "tribunal controlling the administration of the area". ${ }^{96}$ Despite the unwillingness of the mandatories, a system for petitions was finally approved on January 29, 1923 by the Council of the League of Nations. ${ }^{97}$ However, many questions were left open

89 "That the degree of authority, control, or administration exercised by the mandatary State shall in each case be laid down by the League in a special Act or Charter, which shall reserve to it complete power of ultimate control and supervision, as well as the right of appeal to it from the territory or people affected against any gross breach of the mandate by the mandatary State." Smuts, The League of Nations: A Practical Suggestion, 22.

${ }^{90}$ Wilson follows the wording of Smuts in his drafts. See e.g. Wilson's Fourth Draft or Third Paris Draft, February 2, 1919, supplementary agreements III. Reprinted in Miller, Drafting the Covenant, Vol. 2, 153; See also Momirov, 'The Individual Right to Petition in Internationalized Territories: From Progressive Thought to an Abandoned Practice', 217.

${ }^{91}$ Minutes 2 (1922), 15.

92 Pedersen, The Guardians, 83.

93 Chowdhuri, International Mandates and Trusteeship Systems, 205; Hall, Mandates, Dependencies and Trusteeship, 199; Momirov, 'The Individual Right to Petition in Internationalized Territories: From Progressive Thought to an Abandoned Practice', 218; Pedersen, 'Samoa on the World Stage', 235.

94 Pedersen, The Guardians, 83.

${ }^{95}$ Hall, Mandates, Dependencies and Trusteeship, 200.

${ }_{96}$ Chowdhuri, International Mandates and Trusteeship Systems, 206.

97 “(1) All petitions to the League of Nations by communities or sections of the populations of mandated areas should be sent to the Secretariat of the League of Nations through the mandatory Government concerned; the latter should attach to these petitions such comments as it may think desirable.

(2) Any petition from the inhabitants (of mandated areas) received by the Secretariat of the League of Nations through any channel other than the mandatory Government concerned should be returned to the signatories with the request that they should re-submit the petition in accordance with the procedure pre-scribed above. 
and the actual procedures would evolve in the PMC during the years to come, to be finally codified in 1927.98

At the PMC, the question of "consideration of appeals or protests concerning the mandates" were discussed at the very first meeting at the initiative of William Rappard and with the support of Ormsby-Gore. Freire D'Andrade was sceptical about the wisdom of receiving appeals, which he believed would be considerable in number. D'Andrade believed that such protests would probably be settled by the law of the territory. ${ }^{99}$ The majority of the commission was similarly reluctant and agreed that "this point should not be insisted upon". 100 However, by the second meeting, the PMC was already receiving petitions. ${ }^{101}$

Because of the briefness of the 1923 League Council Resolution, the PMC had to start developing procedures for receiving petitions. The petitions from the inhabitants were to be sent to the League of Nations through the mandatory power, which was to attach its own comments. Also different organizations and other individuals could send petitions, and these were received directly by the Mandates Commission. ${ }^{102}$

The petitions had to meet certain criteria to be "receivable". It was not clear whether it was required that the petitioner had exhausted all legal remedies in the mandate. “... [I]t should seem impossible that the Commission should assist persons subject to the jurisdiction to withdraw their cases from the jurisdiction of the territory," Orts noted in a draft resolution relating to the petition of a certain Mr. Robertson. ${ }^{103}$ In general, petitions that could have been decided by local

(3) Any petition regarding the inhabitants of mandated territories received by the Secretariat of the League from any source other than that of the inhabitants themselves should be communicated to the Chairman of the Permanent Mandates Commission. The latter should decide which, if any - by reason of the nature of the contents, or the authority or disinterestedness of their authors - should be regarded as claiming attention, and these should be communicated to the Government of the mandatory Power, which would be asked to furnish, within four months, such comments as it might consider desirable.

(4) All petitions sent to the League of Nations in conformity with the prescribed procedure should, together with the comments of the mandatory Powers, be held and accumulated until the next meeting of the Permanent Mandates Commission.

(5) The Commission, after discussing any petitions received, should decide which, if any, should be circulated to the Council and the Members of the League. The Minutes of the meeting at which the petitions were discussed should be attached." 4 League of Nations Official Journal (1923), 200, 298.

98 Summary of the Procedure to be Followed in the Matter of Petitions concerning Mandated Territories. Minutes 12 (1927), 176-78; Reproduced also in Hall, Mandates, Dependencies and Trusteeship, 315.

${ }^{99}$ Minutes 1 (1921), 29.

100 Ibid., 30. See also Pedersen, 'Samoa on the World Stage', 234; Pedersen, The Guardians, 82.

${ }^{101}$ See eg. Minutes 2 (1922), 76 and Hall, Mandates, Dependencies and Trusteeship, 200.

${ }^{102}$ League of Nations, The Mandates System: Origin, Principles, Application, 38.

${ }^{103}$ Minutes 4 (1924), 139. 
courts could not be received, neither could petitions that questioned the mandate itself or its principles, nor those that were anonymous or repeated the contents of earlier petitions. ${ }^{104}$ However, Chairman Theodoli, annoyed by the reluctance of the French and British mandatories, readily considered petitions to be receivable. ${ }^{105}$

Lugard wrote a note on the general procedure regarding petitions, where he estimated that there would be two different classes of petitions. The first class of petitions included those that were justiciable in the local courts. The second group included those "which could not be dealt with by a local Court and refer to questions of policy or of administrative or executive action on the part of the local officials of the Mandatory Power in regard to which the petitioner has no means of redress". ${ }^{106}$ The purpose for accepting only the latter kind of petitions was that "The Permanent Mandates Commission ... cannot be regarded as a Court of Appeal in matters upon which the local Courts have already adjudicated." 107 As an example of the first category of petitions he mentioned land and mineral rights. ${ }^{108}$ However, the distinction did not prove easy. It was not clear whether an issue was of the type which could be given to local courts to determine. ${ }^{109}$ Lugard also noted that the final decision on which category the petitions would belong to could not be left to local officials. ${ }^{110}$ The problem was that there was no guidance on which petitions to accept and which not. Lugard noted that the Mandates Commission was responsible for "questions affecting the administration of the mandated territory and the general policy followed by the mandatory State so far as it affected the welfare of the inhabitants". ${ }^{111}$ Rappard clarified that while the PMC would not take into consideration appeals of decisions that had been pronounced by Courts in the mandatory territories, it had the authority to act if the petitioner had no juridical remedy because the legislation of the territory was not in conformity with the principles of the mandate or the petitioner had been deprived of judicial remedy due to lack of legislation. ${ }^{112}$ This still left the Commission with a

104 Wright, Mandates under the League of Nations, 171 and 172; Pedersen, 'Samoa on the World Stage', 235.

105 Pedersen, The Guardiand, 85.

106 General Procedures Regarding Petitions. Note by Sir F. Lugard, Minutes 4 (1924), Annex 6, 178.

107 Ibid., 179.

108 Ibid., 179.

109 Cases from the mandates exist in some local courts, especially in South Africa and the A mandates. See section 3.2 above.

110 Minutes 4 (1924), 179.

111 Minutes 6 (1925), 79.

112 Principles which might be Followed by the Permanent Mandates Commission when Determining its Competence in the Matter of Petitions. Note by M. Rappard, Minutes 6 (1925), Annex 9, 168-169. See also Summary of the Procedure to be Followed in the Matter of Petitions concerning Mandated Territories, para. IV, Minutes 12 (1927), 17678. 
rather broad authorization to act. In effect, the authorization was so wide that D'Andrade believed that as there was no document to limit the Commission's competence, therefore the Commission needed to examine every petition. ${ }^{113}$ It was also discussed whether petitions including "violent language" would be admissible, but the PMC concluded that it was not necessary to make a separate decision on that matter. ${ }^{114}$

The procedure was to be as follows. The inhabitants sent the petitions to the mandatory, who, within a six-month period, would send the petitions and its own observations thereupon to the PMC. The PMC adopted a procedure where one of the members would act as a rapporteur and deal with the petition. The PMC would hold a discussion with the mandatory power, come to a conclusion, and submit the conclusion to the Council. If the petition came from other sources than the inhabitants, it would be sent to the Chairman of the PMC,115 who could see which "by reason of the nature of their contents or the authority or disinterestedness of their authors, should be regarded as claiming attention, and which should be regarded as obviously trivial". ${ }^{116}$ No anonymous or "obviously trivial" petitions were accepted. ${ }^{117}$

As experience increased and the PMC would face an increasing number of petitions, the PMC would need to rethink the procedure. In the $23^{\text {rd }}$ session in 1933, Lugard and Palacios had noted that the amount of "trivial" petitions was on the increase, resulting in the waste of the PMC's time. ${ }^{118}$ Palacios had suggested that "the Chairman should use more extensively his right to reject, without further examination, petitions which were non-receivable". ${ }^{119}$ This was suggested after the PMC received a flow of petitions from one single source, none of which had been considered receivable. The Chairman noted that his right to reject petitions included only those that came from outside the mandated territory. Therefore he suggested, "by way of experiment", that the Rapporteur of such a petition could propose the rejection of a petition without further examination and if the PMC agreed, the said petition would be mentioned in a list annexed to the Minutes of the session. ${ }^{120}$ The Chairman had a rather important role in relation to petitions. In addition to being able to determine their receivability, he was also able to affect the outcome of the petitions by choosing a rapporteur whom he believed would

\footnotetext{
${ }^{113}$ Minutes 6 (1925), 80.

${ }^{114}$ Minutes 7 (1925), 133. On violent language in League of Nations minority petitions, see Cowan, 'Who's Afraid of Violent Language? Honour, Sovereignty and ClaimsMaking in the League of Nations'.

115 Minutes 6 (1925), 162-168; Minutes 37 (1939), Annex 3, 127-128; Chowdhuri, International Mandates and Trusteeship Systems, 206.

116 Summary of the Procedure to be Followed in the Matter of Petitions concerning Mandated Territories, Minutes 12 (1927), 176-78.

${ }_{117}$ Chowdhuri, International Mandates and Trusteeship Systems, 206.

118 Minutes 23 (1933), 75-76.

119 Minutes 23 (1933), 76.

${ }_{120}$ Minutes 24 (1933), Annex 4, 114.
} 
consider the petition favourably. Thus, the task of the rapporteur would circulate amongst a few like-minded PMC members. ${ }^{121}$

The Permanent Mandates Commission was divided on whether to publish petitions, as the Commission was anxious about a possible flood of malevolent petitions. Van Rees noted straight out that it "might be dangerous to publish these petitions". They all agreed that "obviously ill-intended or seditious" petitions ought not be published, for the reason that they would encourage more similar ones. However, Rappard concluded that an impartial summary in the reports of the rapporteurs would probably not be harmful.122 Van Rees believed that the following principle on the publishing of petitions should be accepted: "All petitions of a general nature coming from a whole section of the population or from a community and concerned with the general administration should be published, but not individual petitions." 123 Palacios, on the other hand, thought that if one was published, then all must be published. Lugard maintained that publishing petitions would single out everything that had not been considered and thus encourage people to send new petitions. ${ }^{124}$ In the end, the PMC decided to publish the petitions. ${ }^{125}$

One of the open questions regarding the petitions were whether oral hearings for the petitioners would be organized. Again, opinions within the PMC varied. Proponents included Lord Lugard, who felt that the PMC was "competent to hear any one it might desire to hear" and that hearings would increase its impartiality. ${ }^{126}$ On the other hand, he feared that the hearings would burden the PMC and might generate the idea of the subordinance of mandatory powers to the PMC. Rappard was also in favour of the hearings, claiming that they were necessary "to guard against the charge of apparent partiality and to dispel genuine misunderstanding". ${ }^{127}$ Rappard suggested that members of the PMC could meet the people who were approaching them, but that they should be informed of the correct procedures. ${ }^{128}$ The Italian chairman Theodoli pointed out that he had been approached by numerous groups and people that were coming to see him in Rome to talk about their grievances personally. Therefore, he wished to address the PMC to agree on some kind of a procedure. He believed that it was the duty of the PMC to act in a way that showed how all members were serious about their work and thus answer any critique that the whole mandates system existed only to

\footnotetext{
121 Pedersen, The Guardiand, 85.

122 Minutes 6 (1925), 57.

123 Minutes 7 (1925), 137.

124 Minutes 7 (1925), 137.

125 Pedersen, 'Samoa on the World Stage', 235.

${ }^{126}$ Chowdhuri, International Mandates and Trusteeship Systems, 213; Pedersen, 'Samoa on the World Stage', 236.

${ }^{127}$ Chowdhuri, International Mandates and Trusteeship Systems, 213.

128 Minutes 7 (1925), 35.
} 
disguise annexation. ${ }^{129}$ On the contrary, Van Rees (who stated that the PMC had "no legal competency"), Orts (hearings were "undesirable") and Marlin (who claimed that pilgrims would march to Geneva and it would pose too heavy a burden on the PMC) were opposed to the idea. ${ }^{130}$ D'Andrade reminded representatives that the task of the PMC was delicate. If they went too far, the mandatory states would be upset. If they were too careful in setting the limits, it would be claimed that the action of the PMC was only illusory. In his view the PMC needed a procedure that would repel unnecessary and unfounded petitions and those that would malevolently try to affect the members of the PMC. D'Andrade agreed that the Chairman could meet people to discuss matters and use the information gained in the way he wanted. ${ }^{131}$ However, he feared that hearing petitioners would have "an indisputable influence on the minds and opinions of the various members of the Commission". ${ }^{132}$ In the end, the PMC concluded that in exceptional cases "it might appear indispensable to allow the petitioners to be heard by it". ${ }^{133}$ First it was agreed that the Chairman could hear petitioners unofficially, ${ }^{134}$ and in the $9^{\text {th }}$ session in 1926 the PMC accepted the hearing of petitioners in questions where the matter would not otherwise become clear enough. ${ }^{135}$ Official hearings were, however, never arranged. ${ }^{136}$ The mandatory powers were against oral hearings, fearing that the PMC would become a court of law and the hearing would weaken the authority of the mandatory states. ${ }^{137}$ In the end, the Council did not modify the procedure to include oral hearings. ${ }^{138}$

Another controversial issue relating to the petitions were visits to the mandated areas. Lugard, for instance, opposed them as eagerly as he defended hearing the petitioners. ${ }^{139}$ Rappard was, however, prepared to consider a visit. Theodoli saw advantages in visiting territories in principle, but believed that the authorization of such a visit should come from the League Council. Similarly, Van Rees saw the advantages of visits from a theoretical point of view, but in practice found that there were difficulties, not least from the point of view of the prestige of the mandatory. ${ }^{140}$ Palacios, in his report to the petition from the executive

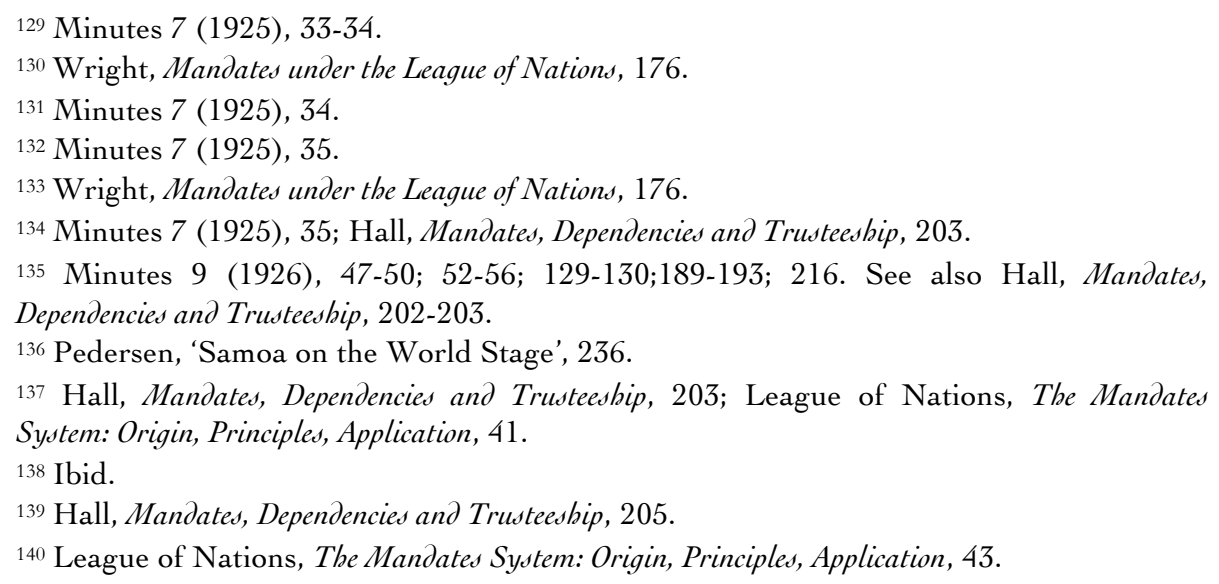


committee of the Palestine Arab Congress, where a request for visitation had been made, noted that a visit to Palestine should be taken into consideration. ${ }^{141}$ Some visits were made with the authorization of the League Council, partly in a private capacity. ${ }^{142}$

The mandatories were openly annoyed by the fact that they had to react to complaints from the mandated territories before the permanent Mandates Commission. "As long as the Commission took the trouble to encourage petitions, so long would they continue", Sir Thomas Wilford, the representative of the New Zealand administration in Samoa complained. ${ }^{143}$ Of the mandatory states, France was the most hostile to petitions and in French Togo and the French Cameroons there were reports of cases where the administration had prevented the inhabitants from petitioning to the League. Also, other mandatories were known to hinder the process. ${ }^{144}$ The Permanent Mandates Commission considered the petitions to be mainly a source of information, and deliberately did not want to turn itself into a court of appeals. ${ }^{145}$ The Commission was careful in its responses to the petitioners. The right of petition would not "create in the minds of the people the idea that the mandatory power is subordinate to the League". "Such an idea would be fatal to the mandatory. Agitators seeking notoriety would endeavour to use this right of petition in order to embarrass the mandatory." ${ }^{146}$

The petitions came from many different sources. Most petitions concerned collective demands but there were individual pleas as well. About 3,000 petitions were received by the League of Nations and a great majority of them came from the A mandates, especially Syria and Palestine, and some organizations even had offices in Geneva to coordinate the petitions. ${ }^{147}$ Some humanitarian organizations sent several petitions, as well as missionaries and lawyers who had noted that rights had been violated. There were, for instance, several petitions concerning South West Africa by the Anti-Slavery Society. ${ }^{148}$ Duncan Hall estimates that in two-thirds of the mandated territories hardly any petitions were written and many had not even heard of such a possibility. In Africa they were mainly written by German immigrants, especially missionaries. ${ }^{149}$ However, concerning New Guinea, Australia denied that the lack of petitions was the result of the natives not

\footnotetext{
${ }^{141}$ See Minutes 7 (1925), Annex 7, 179.

142 Chowdhuri, International Mandates and Trusteeship Systems, 217; League of Nations, The Mandates System: Origin, Principles, Application, 45.

143 Minutes 19 (1930), 56.

144 Pedersen, The Guardians, 84.

145 Wright, Mandates under the League of Nations, 171.

146 Minutes 9 (1926), 191.

147 Pedersen, The Guardians, 86-87.

148 Pedersen, 'Samoa on the World Stage', 238.

${ }^{149}$ Hall, Mandates, Dependencies and Trusteeship, 198.
} 
knowing that such a right existed, but of there not being anything to complain about. ${ }^{150}$

The petition of Kaoko-Land und Minen-Gesellschaft from November 1929 was one of the less common cases, where the PMC did give a recommendation to the Union of South Africa despite having declared that the merits of the petition were such that the case should have been considered by local courts, not by the PMC. The petitioner, a German mining company, complained that a vast area of land that it had purchased from South West Africa natives in 1885 had been expropriated without compensation. The PMC had discussed the case on several occasions during 1928 and 1929,151 and now the rapporteur, Leopoldo Palacios, was starting to be weary of the case: "The question would be less complex if ... the parties to the dispute had not introduced confusion in the form of incomprehensible, if not contradictory, statements." 152

In brief, the petitioner claimed that about 100,000 square kilometres of land was expropriated from the company without compensation and the title deeds had been cancelled. First, the company had claimed that it was too costly to initiate court procedures, ${ }^{153}$ but then maintained that South African courts refused to accept the claim stating that they had no jurisdiction as the applicant company was German. ${ }^{154}$ The petitioner emphasized that it was the owner of the land and had not received the land by a state concession. Therefore, it demanded that South Africa pay compensation for the expropriation as was implied "according to the law of all civilized countries". ${ }^{155}$

South Africa confirmed that it could confiscate properties and concessions without compensation and that in South Africa "individuals have no remedy under any charter of the rights of man against laws which they consider unconstitutional and therefore wrongful". ${ }^{156}$ Thus, South Africa found no reason to even try to claim that it ought to be regarded as a "civilized country" in this respect. ${ }^{157}$ Moreover, as the applicant company was foreign, South Africa believed that the matter should be resolved by diplomatic means between South Africa and Germany.

Palacios did not entirely sympathize with the applicant's demand for compensation, as he pointed out that the vast area of land "must have been bought from the natives for a mere song". ${ }^{158}$ Instead of the mandatory territory (i.e. the

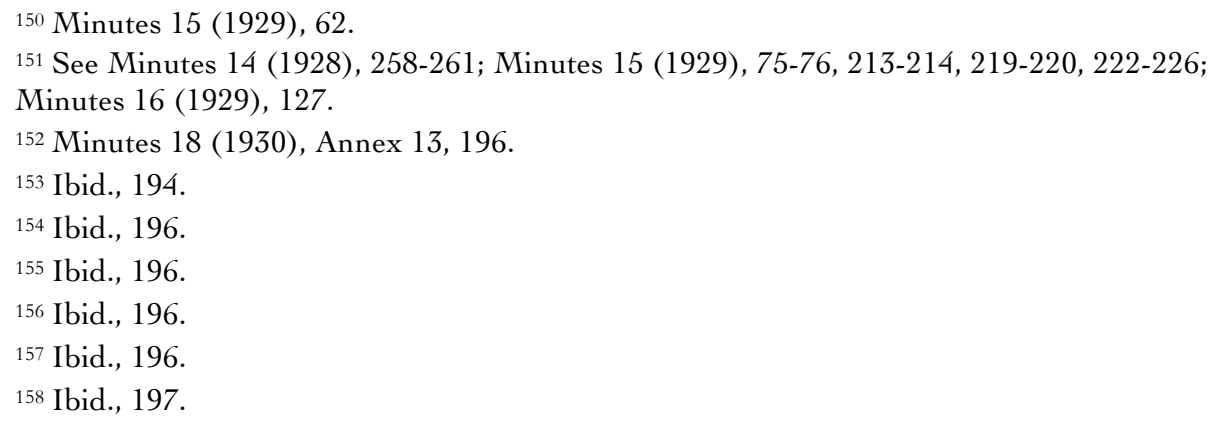


natives) paying for compensation, he would "prefer the Mandates Commission to follow the humanitarian ideals expressed by Lord Lugard in his book 'Dual Mandate' with reference to these original contracts". ${ }^{159}$ Palacios noted that the PMC would be more than willing to declare that in a "modern state" property could not be expropriated without proper legal authorization and fair compensation. It was self-evident that such a declaration could be made even without referring to the "Petition of Rights of 1628 and all the solemn declarations of rights that have been made since that date". ${ }^{160}$ The problem was that such a declaration would make no difference. To study the case and see whether the petitioners' rights had been truly infringed, "we should set ourselves up as a Court of Justice, and we have no authority to do so". ${ }^{161}$ There was, however, one aspect of the petition that Palacios said was within the powers of the PMC. The administration was bound by certain "principles of civilisation and law laid down in the Covenant". ${ }^{162}$ It was the task of the mandatory administration to provide for a venue for grievances, that is, access to local courts. In South West Africa there was now a "certain high-handedness incompatible with the principles of the legal and cultural life of [a civilized] people". ${ }^{163}$ Thus, while the PMC declared itself incompetent in the substantial question, it "called the attention of the Council - in order that the Council may call the attention of the mandatory Power - to the propriety of cancelling the unjust prohibition to submit complaints such as that in the petition ... to the ordinary courts of the territory in question”. ${ }^{164}$

The great majority of the petitions came from Palestine and Syria, and often dealt with concerns of different groups and minorities in these territories. The petition from the Central Agudath Israel of Palestine serves as one example. The petitioners represented the Orthodox Jews of Palestine. They were disappointed because they had not been granted the possibility of organizing as a religious community separate from other Jews. The religious groups in Palestine had been organized as communities, to which certain tasks and advantages had been granted. Such were, for instance, the possibility of acting as a religious tribunal and exercising jurisdiction on a member's personal status (including marriages, divorces, etc.), autonomy in internal affairs, the right to collect taxes, and representation in relation to the government. Knesses Israel had been granted the status of the official organization of the Palestine Jews. A large group of Orthodox Jews had however refused to join Knesses and would rather have formed their own organization. They claimed that the lack of official connection to

159 Ibid., 197. On Lugard's critique of acquisition by treaties, see Lugard, The Dual Mandate in British Tropical Africa, 15-18.

160 Ibid., 198.

161 Ibid., 198.

162 Ibid.

163 Ibid.

${ }^{164}$ Ibid., 199. 
the government led to a situation where laws were passed that infringed their religious rights. ${ }^{165}$

Great Britain as the mandatory refused to give them the official status they were striving for, claiming to want to avoid an unnecessary precedent if other associations of Jews wished to make similar claims. The British also claimed that Jews willing to stay outside the community were free to do so and to form associations if they so pleased.

The PMC recognized that the lack of separate organizations could amount to discrimination on religious grounds. The Orthodox Jewry was not a small group, consisting of approximately $28 \%$ of the entire Jewish population. According to the PMC, they were in essence asked to interpret whether the mandatory complied with Article 2 of the separate agreement for the British mandate in Palestine safeguarding the civil and religious rights of all the inhabitants of Palestine, irrespective of race and religion, and Article 15 granting freedom of conscience and free exercise of all forms of worship and prohibiting discrimination on the grounds of race, religion and language. The PMC concluded that the petitioners had prima facie a strong case as they had been treated differently from other religious groups. However, they wanted to look at the obligations as a whole, and here political obligations stepped in. One aim of the mandate was to establish a National Home for the Jewish people, and the Jewish minority did not wish to see the Jewry divided for this reason. Thus, the aim to build a National Home had to override feelings of discrimination, no matter how real they were. The PMC left the conclusion open, and informed the mandatory that while it would not give any recommendations based on the petition now, it would continue to follow the matter. ${ }^{160}$

Contemporary authors approached petitioning on two levels. First and foremost, it was an important means for the PMC to gather information that would not have otherwise been available to it. ${ }^{167}$ Yet, information was not seen as the only task for petitions. Rather than seeing the PMC merely as a passive organ which just processed information, it was also seen to have an active role in advancing the welfare of native inhabitants. Petitions could be seen as a "means whereby those concerned may state their grievances and secure redress for any wrongs done them". ${ }^{168}$

Similarly, Quincy Wright recognized that one cannot take too strictly the division between petitions for purposes of information, and other complaints for which a local court should be addressed, as "[t]he courts of the mandatory may violate the mandate themselves in giving a decision either through

\footnotetext{
165 Minutes 22 (1932), Annex 14, 335.

166 Ibid., 338-339.

${ }^{167}$ See League of Nations, The Mandates System: Origin, Principles, Application, 38; Wright, Mandates under the League of Nations, 169.

${ }^{168}$ League of Nations, The Mandates System: Origin, Principles, Application, 38.
} 
misinterpretation of the law or because the law is in conflict with the mandate". ${ }^{169}$ Thus, while information was the "primary object" of petitions, they also ensured that "grievances will receive careful consideration" and in case of violations, provide remedies. ${ }^{170}$

James Hales, writing in 1939, saw an even broader meaning to petitions: "For the first time in colonial history, the administrators are made to answer challenges from those whom they administer, before an independent Commission," ${ }^{171}$ he said. "[The rules concerning the petitions] marked a stage in the progress towards open dealing in colonial administration." ${ }^{172}$

In retrospect, the right to petition has been considered by some authors to be the most important human rights feature in the mandates system and as such, was applauded by several authors writing immediately after the Second World War. Hersch Lauterpacht, for instance, called the right of petition a "natural right"173 and a "fundamental right", 174 and maintained that the "right of petition was regarded as a natural concomitant of the system established by the Covenant". ${ }^{175}$ In his view, the hearing of petitions was one of the main features of the mandates system. ${ }^{176}$ Lauterpacht, however, was not describing the meaning of petitions in the mandates (and the League minority treaties) as such. Instead he was arguing that the human rights clauses in the United Nations Charter will never serve their full purpose unless a similar right to petitions was inserted.177 Similarly, William Rappard included petitions in his list of features relevant to the protection of human rights. He, however, viewed petitions mainly as a source of information. According to him, the contribution of the mandates system to the protection of human rights was (apart from the guarantees given to the inhabitants) in the information elicited from the mandatory governments, gained from the petitions and other oral information received from the Mandates, the communication of this information to the League of Nations organs and the publishing of the information to the general public. Rappard writes, "I doubt very much whether any flagrant and persistent violation of any of the clauses of the Mandate could have escaped the vigilance of the Mandates Commission". ${ }^{178}$

\footnotetext{
${ }^{169}$ Wright, Mandates under the League of Nations, 171.

170 Ibid., 462.

171 Hales, 'The Creation and Application of the Mandate System. (A Study in International Colonial Supervision)', 224.

172 Ibid., 227.

${ }^{173}$ Lauterpacht, International Law and Human Rights, 244.

174 Ibid., 251.

175 Ibid., 244.

176 Ibid., 245.

177 Ibid., 244 and 251.

${ }^{178}$ Rappard, 'Human Rights in Mandated Territories', 121.
} 
Duncan Hall considers petitions to be "one of the main and most interesting innovations of the mandates system", calling it a "natural right". ${ }^{179}$ In Hall's view, the value of petitions was theoretical rather than practical. ${ }^{180}$ Chowdhuri also treated petitions similarly: "The right of petition, which is one of the fundamental human rights, is one of the most important factors in the operation of the Trusteeship system." 181 However, he found a great difference between petitions in the mandates system and the trusteeship system. In the former he saw them mainly as a source of information, whereas in the latter, it was one of the most important features of the entire system. ${ }^{182}$

What is common to these authors was that they did not claim in retrospect that petitioning brought a human rights feature into the mandates period, but they were aware of its potential in the new era of human rights. Lauterpacht argued for the right to petition in the United Nations, while both Hall and Chowdhuri saw the theoretical possibilities of petitions, Chowdhuri giving it a greater importance in the trusteeships. Rappard would not have even started to think about petitions from the point of view of human rights had he not been given the specific task of doing so.

Concerning more recent accounts, Susan Pedersen maintains that the meaning of petitions was in the fact that they forced the responsible administration to reveal the logic of the system and the petitions and their treatment revealed the authoritarian structures of the system and racial hierarchies. ${ }^{183}$ Using Samoa as an example, Pedersen has described how meagre the effects of petitions on the lives of the inhabitants of a mandated territory were, at least initially. ${ }^{184}$ Pedersen has noted that the attitude towards petitions in the PMC reveals that the Commission believed in formal rules, paternalistic ideals and the authority of the administration, and for petitioners it was a difficult route to get their voices heard. ${ }^{185}$ However, in some mandates the petitions were a useful method of revealing grievances to the Permanent Mandates Commission, which was mainly dependent on the reports of the mandatories for information. In some cases, like the Samoan petitions, they in the end initiated processes that otherwise would have not taken place. ${ }^{186}$ On the other hand, Aleksandar Momirov has seen

\footnotetext{
${ }^{179}$ Hall, Mandates, Dependencies and Trusteeship, 198; Hall cites Norman Bentwich, who said that "the inhabitants ... at once assumed that such a right existed". Bentwich, The Mandates System, 114.

${ }_{180}$ Hall, Mandates, Dependencies and Trusteeship, 198.

181 Chowdhuri, International Mandates and Trusteeship Systems, 208.

182 Ibid.

183 Pedersen, 'Samoa on the World Stage', 233.

184 Ibid., 240.

185 Ibid., 254.

186 Pedersen, 'Samoa on the World Stage'.
} 
the petitioning procedure in a more positive light, emphasizing accountability, ${ }^{187}$ the novelty of contact between individuals or interest groups and the "international community" 188 and the inclusiveness of the right, as there was no requirement of a citizenship, residentship or even physical presence on the territory. ${ }^{189}$

The institution of petitions from mandates was a late invention in the operation of the PMC and their form and function were a source of much concern within the PMC. It was a matter of debate whether the PMC could or should be a Court or a recipient of appeals, who would be able to appeal and what possibilities would the PMC have to act on these petitions. Like much of the operation of the PMC, the system of petitions was a compromise. As there was no organization representing the inhabitants beyond the administration, the right to petition was granted to both individuals and groups. The petitions were, however, presented to the mandatory who would then be required to forward them to the PMC. The PMC would in turn consult the mandatory power and a rapporteur would be appointed. Balancing between the desire not to antagonize the mandatory powers on the one hand, and building a purposeful process on the other hand, proved difficult. As the system would become operational, it was felt that too many of the petitions were trivial and the PMC members wished to restrict so-called trivial petitions. In all of these debates it is clear that basic elements of legal proceedings such as granting a hearing to petitioners were still not settled. Though the system of petitions was fairly limited in its extent, it nevertheless managed to annoy the mandatories. Many of the petitions were drafted by European philanthropic organizations or Christian missions. What was even more troubling was that in fairly many areas no petitions at all were brought forward, leading to questions whether petitions had been suppressed. In its discussions the members of the PMC were often less than understanding about petitions. Many were disparaged and thought to be trivial, in others the members would reflexively side with the administration. Thus while the first historians of the system of petitions hailed the system of petitions as a virtuous guarantor of human rights, the reality was much more mundane. While the system of petitions allowed the PMC to gain information about grievances and issues in the administration, for the most part it had very little effect in the lives of the inhabitants of the mandates.

\footnotetext{
187 Momirov, 'The Individual Right to Petition in Internationalized Territories. From Progressive Thought to an Abandoned Practice', 206.

188 Ibid., 223.

189 Ibid.
} 


\section{The Emergence of Rights Language and the South West Africa Cases of the International Court of Justice}

While the relevance of the League of Nations ended with the founding of the United Nations and the League mandates it had established were turned into UN trusteeships, the mandates continued their relevance in international law through the International Court of Justice Mandates cases. ${ }^{1}$

The purpose of this chapter is to examine the reinterpretation of the mandates system by the International Court of Justice, especially through the interpretation of the idea of self-determination and its implications in the era of decolonization. In this process the discussions are expressed increasingly through the language of rights. Of the three sets of cases, ${ }^{2}$ I will limit my examination to the cases concerning South West Africa (later Namibia). In these cases, the ICJ revisits several times the meaning and content of the mandates, finally approaching them through the language of human rights. The cases demonstrate the slow realization of the Court to the political realities of the decolonizing world. While the 1950 case sought to reaffirm the continuation of the obligations of South Africa as a mandatory and, by extension, to reject the aims of annexation by South Africa, the later cases were about protecting the rights of the inhabitants of the mandate and ultimately about the system of apartheid practised by South Africa. In the first 1950 advisory opinion, sought by the United Nations General Assembly, the Court outlined that the obligations of the mandate continued to bind South Africa. In the cases of 1962 and 1966, the Court was faced with numerous claims from the applicants, Ethiopia and Liberia, but the bulk of the proceedings were about the jurisdiction of the Court. The case never entered the merits phase, where issues such as whether South Africa would be violating the rights and liberties of the inhabitants of the mandate would have been discussed. When the Court rejected the case in 1966 based on strict formalistic argumentation, there was an uproar, especially from the developing world. As a consequence, on the suggestion of Finland, the Security Council made a new request for an advisory opinion to the Court. In its advisory opinion in 1971, the Court reversed its position and found

\footnotetext{
${ }^{1}$ Syria and Lebanon, both part of the former Syrian mandate, became independent in 1946.

${ }^{2}$ Certain Phosphate Lands in Nauru (Nauru v. Australia). Preliminary Objections, Judgment, I.C.J. Reports 1992, 240; Case concerning the Northern Cameroons (Cameroon v. United Kingdom) (Cameroon v. United Kingdom), Preliminary Objections, Judgment of 2 December, 1963: I.C.J. Reports 1963, 15; International Status of South West Africa, Advisory Opinion: I.C.J. Reports 1950, 128; South West Africa Cases (Ethiopia v. South Africa; Liberia v. South Africa), Preliminary Objections, Judgment of 21 December, 1962: I.C.J. Reports, 1962, 319; South West Africa, Second Phase, Judgment, I.C.J. Reports 1966, 6; Legal Consequences for States of the Continued Presence of South Africa in Namibia (South West Africa) notwithstanding Security Council Resolution 276 (1970), Advisory Opinion, I.C.J. Reports 1971, 16.
} 
South Africa to be in violation of its obligations as a mandatory. In this chapter, the aim is to discuss not only the evolution of the reasoning of the Court, but equally the changes in the legal and political landscape and its implications for the understanding of human rights and colonialism.

Within the mandates system, the continued presence of South Africa and its willingness to annex it was an anomaly after the Second World War. Most of the A mandates (Syria and Lebanon, Palestine) had become independent immediately after the war, while most of the mandates in Africa first became UN Trust territories and then gained independence along with the French and British African colonies in the early years of the 1960s (British and French Cameroons, British and French Togo, Tanganyika, Ruanda-Urundi). The Pacific mandates (New Guinea, Nauru, Samoa, and the South Pacific Mandate) were transformed into UN trusteeships with the ultimate goal of self-government and independence.

Even though the stated objective of the mandate system had been to guide the mandated areas towards the goal of independence, that had been considered merely a theoretical possibility with regard to many of them, especially the mandates of Africa and the Pacific. Those calculations changed dramatically due to the rapid unravelling of the European colonial empires after 1945. The independence of India and Pakistan in 1947 and Indonesia in 1949 began a wave of decolonization that swept first Asia and then Africa. The 1955 Asian-African Conference of Bandung solidified the movement against colonialism. Anticolonialism was a rare movement during the Cold War as it was supported by the US, the Soviet Union, as well as the non-aligned countries. By the end of the 1960s, the only remaining colonies in Africa were Angola and Mozambique held by Portugal, and ruled by a military dictatorship, and South West Africa held by South Africa. The second consequence of the decolonization was the entry to the UN by the former colonies, changing the balance of power in the General Assembly.

The foundation of the UN and the 1948 Universal Declaration of Human Rights were a tremendous boost to the prominence of human rights. While their emergence may be seen as reactions to the horrors of totalitarianism and the Second World War, such as the Holocaust, they became equally important in the Western self-understanding during the Cold War and the perceived totalitarianism of the Communist regimes. In the US, the civil rights movement had long advocated against racial segregation, especially in the South. With judicial victories like the 1954 Brown v. Board of Education, ${ }^{3}$ the idea of equal rights began to take hold. Against this background, the fact that South Africa, which had long practised racial segregation, began in 1948 to implement a policy of comprehensive segregation based on race called apartheid, was another anomaly. The apartheid system was an antithesis to the idea of equal rights, mandating segregated education, health care and even residential areas. It even deprived the

\footnotetext{
${ }^{3}$ Brown v. Board of Education of Topeka, 347 U.S. 483 (1954).
} 
non-white population of citizenship and political rights. Through forced removals, millions were relocated into so-called segregated neighbourhoods and Bantustans. From the beginning, the apartheid system caused international protest and led to different sanctions against South Africa, gradually turning it into a pariah state. Like the separate but equal laws used in the US, the apartheid laws enforced a segregation based on ethnicity and race. Like in the US, the system was perfectly legal under national law. Due to wide resistance and protests, maintaining apartheid led to the formation of a police state and the use of terror against dissenters. The issue of apartheid was one of the most blatant contradictions between the ideas of universal human rights and national sovereignty.

The United Nations took shape in a series of meetings and documents, all having varying relevance to the growth of human rights, self-determination and the independence of colonial states.

The Atlantic Charter of 1941, a declaration signed by Theodore Roosevelt and Winston Churchill on issues relating to peace and future relations between states, did include a mention of self-determination to all peoples, as well as "the assurance that all the men in all lands may live out their lives in freedom from fear and want". ${ }_{4}$ The Charter has, however, received contradictory interpretations on its meaning concerning the development of human rights. Arguing for a minimalist interpretation, Samuel Moyn does not consider it a human rights document, noting that it did not include the phrase "human rights". ${ }^{5}$ On the other hand, Seth Mohney maintains that Moyn ignores the real impact of the document by concentrating his attention on the verbal formulations of the document. In his view, the meeting between Roosevelt and Churchill "produced one of the most influential, non-binding human rights documents in history". ${ }^{6}$

In the autumn of 1944 the allied states of World War II met at Dumbarton Oaks to negotiate the setting up of a new international organization. Initially, the participants were the United States, United Kingdom and the Soviet Union, while China, being excluded from the preliminary negotiations of the Conference, would join the discussions at a later stage. ${ }^{7}$

Human rights did not play a great role in the discussions, but internationalists were keen to see them included. Roosevelt had favoured a universalistic interpretation of the Atlantic Charter, and was prepared to include some reference to human rights in the Dumbarton Oaks negotiations as well. ${ }^{8}$ Roosevelt, who was torn on the domestic front between internationalists and isolationists, suggested a clause giving each state the task to respect human rights and fundamental

${ }^{4}$ Atlantic Charter, August 14, 1941.

${ }^{5}$ Moyn, The Last Utopia: Human Rights in History, 89.

${ }^{6}$ Mohney, 'The Great Power Origins of Human Rights', 836.

7 Ibid., 838. See also Hilderbrand, Dumbarton Oaks; Simpson, Great Powers and Outlaw States, 173.

${ }^{8}$ Mohney, 'The Great Power Origins of Human Rights', 839. 
freedoms, while at the same time protecting domestic sovereignty. ${ }^{9}$ However, the British and the Soviets feared that a mention of human rights opened an opportunity to criticize members of the new organization. ${ }^{10}$ At the same time, the Chinese suggested including a clause on the principle of equality of all states and races, which was, however, not acceptable to the other participants. ${ }^{11}$ In the final document a mention of human rights was included, but it was buried under "arrangements for international economic and social cooperation":

With a view to the creation of conditions of stability and well-being which are necessary for peaceful and friendly relations among nations, the Organization should facilitate solutions of international economic, social and other humanitarian problems and promote respect for human rights and fundamental freedoms. ${ }^{12}$

Thus, the task to safeguard human rights was moved from states, as Roosevelt had initially suggested, to the United Nations. The role of human rights in the final document remained insignificant. ${ }^{13}$ Moyn states that the purpose of the conference was to balance the great powers, not to create a moral code for the international community. According to him, human rights had not yet obtained such a role in international language that they could be used to justify an international organization. Rather, their task was to promote the organization to the general audience. ${ }^{14}$ However, public opinion and many governments were critical towards what was achieved in terms of human rights at Dumbarton Oaks, and especially the Americans could not ignore such critique without further consideration. The final United Nations Charter would thus feature human rights in a more prominent way. ${ }^{15}$

A large role has been given to initiatives by Latin American countries as well as by American NGOs, for including a broader reference to human rights in the UN Charter, as compared to the Dumbarton Oaks negotiations. ${ }^{16}$ Latin American

9 Ibid.; Mazower, 'The Strange Triumph of Human Rights, 1933-1950', 392.

${ }^{10}$ Mazower, 'The Strange Triumph of Human Rights, 1933-1950', 391.

${ }^{11}$ Ibid.; Burgers, 'The Road to San Francisco: The Revival of the Human Rights Idea in the Twentieth Century', 474; Lauren, 'Human Rights in History Diplomacy and Racial Equality at the Paris Peace Conference', 9-13.

12 Washington Conversations on International Peace and Security Organization. October 7, 1944. Chapter IX 1.

13 Burgers, 'The Road to San Francisco: The Revival of the Human Rights Idea in the Twentieth Century', 474; Mazower, 'The Strange Triumph of Human Rights, 1933-1950', 391; Moyn, The Last Utopia: Human Rights in History, 56.

${ }^{14}$ Moyn, The Last Utopia: Human Rights in History, 56-57.

${ }_{15}$ Mazower, 'The Strange Triumph of Human Rights, 1933-1950', 392; Mohney, 'The Great Power Origins of Human Rights', 341.

${ }_{16}$ Mohney, 'The Great Power Origins of Human Rights', 841; Burgers, 'The Road to San Francisco: The Revival of the Human Rights Idea in the Twentieth Century', 475. 
countries had held a conference at Chapultepec, Mexico, where they had decided to promote the inclusion of human rights in the Charter as well as a declaration of human rights. ${ }^{17}$ The US delegation to the San Francisco Conference in the spring and summer of 1945, on the other hand, had decided to include several NGOs in a consultative role. The United States was careful not to repeat the previous embarrassment when the US Senate would not accept the Covenant of the League of Nations, and was willing to accept suggestions by the NGOs to support a broader inclusion of human rights to the United Nations Charter. ${ }^{18}$ In order to secure domestic support, the United States needed to take the general opinion of the American audience into account. ${ }^{19}$

While smaller states now at the San Francisco Conference had an opportunity to participate by working in various drafting committees, the great powers still dominated the negotiations. ${ }^{20}$ The number of references to human rights increased from the Dumbarton Oaks negotiations, to be now included in several articles of the United Nations Charter:

Preamble:

[...] to reaffirm faith in fundamental human rights, in the dignity and worth of the human person, in the equal rights of men and women and of nations large and small $[\ldots]$

Chapter I. Purposes and Principles

Article 1.3

To achieve international cooperation in solving international problems of an economic, social, cultural, or humanitarian character, and in promoting and encouraging respect for human rights and for fundamental freedoms for all without distinction as to race, sex, language, or religion; [...]

Chapter IV. The General Assembly:

Article 13.1 The General Assembly shall initiate studies and make recommendations for the purpose of:

$[\ldots]$

b. promoting international co-operation in the economic, social, cultural, educational, and health fields, and assisting in the realization of human rights and fundamental freedoms for all without distinction as to race, sex, language, or religion.

\footnotetext{
${ }^{17}$ Burgers, 'The Road to San Francisco: The Revival of the Human Rights Idea in the Twentieth Century', 475; Lauren, The Evolution of International Human Rights: Visions Seen, 168-170.

18 Burgers, 'The Road to San Francisco: The Revival of the Human Rights Idea in the Twentieth Century', 476.

${ }^{19}$ Mazower, 'The Strange Triumph of Human Rights, 1933-1950', 392.

${ }^{20}$ Mohney, 'The Great Power Origins of Human Rights', 842.
} 
Chapter IX. International Economic and Social Co-operation Article 55

With a view to the creation of conditions of stability and well-being which are necessary for peaceful and friendly relations among nations based on respect for the principle of equal rights and self-determination of peoples, the United Nations shall promote:

$[\ldots]$

c. universal respect for, and observance of, human rights and fundamental freedoms for all without distinction as to race, sex, language, or religion.

Article 62

1. The Economic and Social Council may [...]

2. ... make recommendations for the purpose of promoting respect for, and observance of, human rights and fundamental freedoms for all.

$[\ldots]$

Article 68

The Economic and Social Council shall set up commissions in economic and social fields and for the promotion of human rights, and such other commissions as may be required for the performance of its functions.

Chapter XII. International Trusteeship System

Article 76

The basic objectives of the trusteeship system, in accordance with the Purposes of the United Nations laid down in Article 1 of the present Charter, shall be:

$[\ldots]$

c. to encourage respect for human rights and for fundamental freedoms for all without distinction as to race, sex, language, or religion, and to encourage recognition of the interdependence of the peoples of the world; $[\ldots]$

The preambular clause was suggested by Jan Smuts from South Africa, which shows that he did not believe it to be contradictory in any manner to South Africa's practices. ${ }^{21}$ Despite the added references to human rights, the great powers ensured that the emphasis on domestic jurisdiction remained strong. ${ }^{22}$

${ }^{21}$ Moyn, The Last Utopia: Human Rights in History, 61.

22 Mohney, 'The Great Power Origins of Human Rights', 844-845; Mazower, 'The Strange Triumph of Human Rights, 1933-1950', 393; Lauren, The Evolution of International Human Rights: Visions Seen, 187-188. 
Article 2.7

Nothing contained in the present Charter shall authorize the United Nations to intervene in matters which are essentially within the domestic jurisdiction of any state or shall require the Members to submit such matters to settlement under the present Charter; but this principle shall not prejudice the application of enforcement measures under Chapter VII.

The powers also made sure that none of the human rights clauses were directly enforceable. Thus, they could be sure that they themselves could not be criticized based on such articles. ${ }^{23}$

Moyn maintains that the UN Charter was merely a repetition of the Dumbarton Oaks Agreement. In his view, the meeting at San Francisco was concentrated on the issues of the balance of power and national sovereignty, and human rights were left a marginal role in legitimizing the new international organization and bringing support from the general audience. Thus, he sees the human rights notions in the Charter as merely symbolic, stressing also the insignificant role of the Economic and Social Council. ${ }^{24}$ However, this minimalist view may be seen as exaggerated if one takes into account the pervasive nature of the human rights language in the founding documents.

There was naturally a continuation from the mandates system to UN Trusteeships that were established in the UN Charter. ${ }^{25}$ After all, all mandates, with the exception of South West Africa and Syria were turned into trusteeships as the League and its mandates system ceased to exist. Like the mandates system, the trusteeship system was similarly based on the idea of a "sacred trust", as can be found in Article 73 of the United Nations Charter. ${ }^{26}$ US President Roosevelt had suggested the trusteeships. His idea was to put all colonial possessions under international governance until they became independent. Churchill objected to the plan, and accepted only a limited system of trusteeship. This meant that he would accept only the former mandates to be placed under the trusteeship system. Finally, the five permanent members of the United Nations all suggested their own formulations for the trusteeships. The Assembly of the League of Nations terminated the mandates in its last meeting of April 18, 1946. The trusteeship agreements were approved on December $13,1946 .^{27}$

${ }_{23}$ Mazower, 'The Strange Triumph of Human Rights, 1933-1950', 394.; Lauren, The Evolution of International Human Rights: Visions Seen, 188.

${ }^{24}$ Moyn, The Last Utopia: Human Righto in History, 59-62.

25 Simma et al., The Charter of the United Nations, 1887. The first United Nations preparatory document to include the idea of a Trusteeship System was the Protocol of Proceedings of the Crimea Conference, signed by Joseph Stalin, Franklin D. Roosevelt and Winston Churchill on February 11, 1945.

26 Toussaint, The Trusteeship System of the United Nations, 10. See also Rappard, 'Mandates and Trusteeships'.

${ }^{27}$ Simma et al., The Charter of the United Nations. A Commentary, 1844-1845. 
Yet, there were great differences between the two regimes, the most important being the composition of the organs that supervised the system. ${ }^{28}$ The Permanent Mandates Commission had consisted of independent experts, who, at least on some occasions, took pride in their neutral handling of the territories and their administration. However, the UN Trusteeship Council consisted of members representing their governments, and half of the members represented the administering nations. ${ }^{29}$ At the same time, the United Nations General Assembly, the task of which was to approve the terms of the trusteeship agreements and of their alteration or amendment and act as an authority for the Trusteeship Council,30 was becoming flooded with new members. The number of member states in the UN had increased from 51 to 99 between 1945 and 1960.31 Many of these new members were former colonies, and it was understandable that their relationship to the trust territories differed from the administering nations, most of them being old colonial powers.

Not all colonies became trusteeships, but the system applied only to former mandates, territories that had formerly been a part of enemy states, and areas that were voluntarily placed under the system. Thus, the colonial powers were able to keep their colonies regardless of a new mode of colonial administration. The Charter allowed the designation of certain territories as "strategic areas" and to be placed under the auspices of the Security Council, where the permanent members were thus able to exercise control over them. This possibility was readily used by the US, as Carolina, Mariana and Marshall Islands were designated as "strategic areas" ${ }^{32}$

To the administering countries issues such as self-government, the underlying goal of the trusteeship system did not necessarily mean a promise of independence. The British historian Duncan Hall describes this as an improvement in the mandates system, where independence was explicitly recognized in the A mandates. According to him (and the administering states), it was better to support a true self-government that could take a variety of forms rather than independence, which could lead to instability in the form of a puppet government or at worst a dictatorship. He maintained that the world was too fragmented and would benefit from cooperation rather than division. ${ }^{33}$ On the other hand, the newly independent states claimed that independence had been

${ }^{28}$ Goodrich, 'From League of Nations to United Nations', 18-19; Sayre, 'Legal Problems Arising from the United Nations Trusteeship System', 265-268.

${ }^{29}$ Murray, The United Nations Trusteeship System, 119.

${ }^{30}$ United Nations Charter, Article 85.

$31 \mathrm{http} / /$ www.un.org/en/sections/member-states/growth-united-nations-membership1945-present/index.html. Accessed May 13, 2016.

${ }^{32}$ Lauren, The Evolution of International Human Rights: Visions Seen, 187.

${ }^{33}$ Hall, Mandates, Dependencies and Trusteeship, 280. 
promised to the mandates already during the League period and there was no reason to diverge from this. ${ }^{34}$

A similar division was apparent in a range of matters relating to the trusteeships. The colonial powers were hostile to a suggestion that trust territories could send their own (native) representatives to the Trusteeship Council. Similarly, ideas differed on how self-government would be realized and how the inhabitants of trust territories would be given the chance to voice their wishes. ${ }^{35}$ The administering states were opposed to suggestions on how the UN could follow the processes towards independence, or the need to set a time limit for independence. However, the General Assembly required the administering states to give an estimate of all actions that were done to advance the independence of the trust territories and how they were advancing.

The division between the Trusteeship Council and the General Assembly led to the fact that many decisions concerning the trust territories were bounced back and forth between these organs. Matters important to the new states of the General Assembly could be pending for a long time, as the Trusteeship Council would disregard it or consider it inappropriate. ${ }^{36}$ As the General Assembly had no means to enforce its decisions, it could only continue giving resolutions over and over again concerning the same matters.

The basic objectives of the trusteeship system were to "promote the political advancement of the inhabitants of the Trust Territories, and their progressive development towards self-government or independence". ${ }^{37}$ The same questions about rights would follow from the mandates to the trusteeships. The local inhabitants would still petition on issues such as local lands being given to the use of foreigners. ${ }^{38}$ Also discussions concerning slavery, forced labour and the position of women would continue into the trusteeship period. Moreover, despite the new specific articles on human rights in the trust territories, discussions relating to these "social matters" were to some extent similar to those in the mandates. For instance, as Karen Knop has shown, the position of women was discussed in the Trusteeship Council as something that would evolve gradually, due to increased contact with civilization and the European model. ${ }^{39}$

34 Chowdhuri, International Mandates and Trusteeship Systems: A Comparative Study, 53; Murray, The United Nations Trusteeship System, 41.

${ }^{35}$ Luard, A History of the United Nations, Volume 2, 143.

${ }^{36}$ Luard, A History of the United Nations, Volume 2, 121-122, 127.

${ }^{37}$ United Nations Charter, Article 76. Meredith Terretta considers the trusteeships to be central to the connection between human rights and decolonization. Terretta, 'We Had Been Fooled into Thinking That the UN Watches over the Entire World', 358.

${ }^{38}$ Chowdhuri, International Mandates and Trusteeship Systems: A Comparative Study, 278.

${ }^{39}$ See discussion in section 3.6 above. 
A conference of non-aligned states of the third world was held in Bandung, Indonesia, in April 1955.40 The initiative had been made by Indonesia, and the idea was to gather states from Asia and Africa to a common conference, and thus to bring them closer together.

The Final Communiqué of the Bandung Conference (also called the AfroAsian Conference) discussed issues such as economic and cultural co-operation, but also human rights, self-determination and, more generally, the problems of dependent peoples. ${ }^{41}$

In later accounts of the conference much emphasis has been put on the stress placed on human rights and the rights to self-determination at the conference. Roland Burke, for instance, has maintained that human rights reached their highpoint in third world countries during the conference. ${ }^{42}$ According to him, human rights were central in the discussions in Bandung as it was through human rights that the participants could articulate matters that they were striving for. The participants accepted the Universal Declaration as an existing normative standard and, at least in principle, human rights were declared as universal, though there was much debate on the details. ${ }^{43}$ For some of the participants the struggle against colonialism was a struggle for human rights. ${ }^{44}$ Burke maintains that even when there was much emphasis on the sovereignty of states, a majority of the speakers did not see a contradiction between sovereignty and human rights. Human rights were perceived as a tool with which colonialism could be challenged, and thus human rights and self-determination were seen to support each other. ${ }^{45}$ Instead of criticizing human rights as a Western creation, the participants supported them as useful for their own purposes. Thus, Burke concludes, some of the important achievements of the Bandung Conference were that especially small Asian states gave their support to the Universal Declaration of Human Rights, as well as the discussions on human rights, including individual rights, freedom of religion and democratic governance. ${ }^{46}$

However, Burke's view has been criticized as one-sided. Samuel Moyn, for example, notes that in Bandung, self-determination was seen as the primary human right, to which other rights were subordinate. ${ }^{47}$ Thus, in order for other

${ }^{40}$ Generally on the Bandung Conference, see Ampiah, The Political and Moral Imperatives of the Bandung Conference of 1955; Lee, Making a World After Empire.

${ }^{41}$ Final Communiqué of the Asian-African Conference of Bandung (24 April, 1955).

${ }^{42}$ Burke, Decolonization and the Evolution of International Human Rights, 14-15.

${ }^{43}$ Ibid., 19, 21.

${ }^{44}$ Ibid., 20.

45 Ibid., 25-26, 34.

46 Ibid., 33.

${ }^{47}$ Moyn, The Last Utopia: Human Rights in History. See also Bandung Final Communiqué C.1. Christian Reus-Smit is critical of Moyn's argument that postcolonialism and human rights had nothing to do with each other. Reus-Smit, Individual Rights and the Making of the International System, 166. 
rights to materialize, self-determination would be required. According to Moyn, the participants of the Bandung Conference did not mean individual rights by human rights. This also explains why human rights and national sovereignty did not seem to contradict each other. If by human rights one means the right to selfdetermination, an emphasis on sovereignty naturally follows. 48

Jan Eckel has also noted that post-colonial states used the language of human rights to strengthen their demands. Therefore, self-determination and racial equality were presented as human rights. ${ }^{49} \mathrm{He}$ pointed out that at Bandung, human rights were only one theme amongst many others, and one should not exaggerate their importance. He also stressed that human rights were defined to mean one, politically convenient purpose: self-determination. According to Eckel, expressing colonial experiences using a novel international language gives a clear example of how the idea of human rights is redefined according to anticolonial principles. ${ }^{50}$

\subsection{The Continuation of the Mandate Without the League: The 1950 Advisory Opinion on the International Status of South West Africa}

While the other mandates were transferred to the UN trusteeship system after the Second World War, South Africa had informed the United Nations of its plan to annex South West Africa. This would only have required the approval of the United Nations. The General Assembly did not approve of the plan and demanded that the mandate be changed into a trusteeship. South Africa refused. It sent one more annual report to the United Nations but then began strengthening its policy of apartheid also in South West Africa. ${ }^{51}$ The fate of the territory produced numerous resolutions from 1946 onwards in the General Assembly and the Security Council of the United Nations.

The aim of this section is to discuss the first legal response by the UN to the South African plans for annexation. In 1949 it requested an advisory opinion from the International Court of Justice (ICJ) regarding whether the mandate obligations continued and whether the provisions of the new trusteeship system would apply. Lastly, it requested the Court to clarify the international status of South West Africa. The response of the Court ensured that not only would the issue of South West Africa remain on the international agenda, but also it laid the foundation for the interpretation of the mandate system through the language of rights. It found that the mandate and its obligations continued despite the fact that the League of Nations, the contracting party in the mandate, ceased to exist. Secondly, it redefined the concept of sacred trust through the concepts of nonannexation and development, granting the UN not only the powers of supervision

\footnotetext{
${ }^{48}$ Moyn, The Last Utopia: Human Rights in History, 96, 108.

${ }^{49}$ Eckel, 'Human Rights and Decolonization', 117.

${ }^{50}$ Ibid., 118.

${ }^{51}$ Landis, 'The South West Africa Cases: Remand to the United Nations', 630.
} 
of the protection of the rights of the mandated territories, but also enabling it to receive petitions. Finally, it defined the international status of South West Africa to be beyond the powers of South Africa to modify.

$* * * * *$

In its 1949 request, the General Assembly asked the Court to clarify three questions. Firstly, does the Union of South Africa continue to have international obligations under the mandate of South West Africa, and if it does, what are those obligations? Secondly, are the provisions of Chapter XII of the United Nations Charter, concerning the newly-established trusteeships, applicable to the territory of South West Africa? Thirdly, does South Africa have the competence to modify the international status of South West Africa, and if it does not, who can determine and modify the international status of the territory?

The Court found two important principles to apply to the mandate, namely the principle of non-annexation and the well-being and development of peoples forming a "sacred trust of civilization". ${ }^{52}$ According to these principles it was clear that it was not acceptable to cede any territory or transfer any sovereignty to South Africa without violating the mandate. South Africa had used private law analogies to support its claim that due to the lapse of the mandate it was free to annex the South West African territory into its own. The Court, however, noted that the mandate was regulated by international rules. These rules exceeded any such contractual relations that would be regulated by national law. Therefore, no national law analogies would be relevant to the outcome of the case. Moreover, the international rules were created "in the interest of the inhabitants of the territory, and of humanity in general ... with an international object - a sacred trust of civilization". ${ }^{53}$ Thus, a lot more was at stake than mere norms and interpretation of various national forms of mandate. The Court confirmed that the mandate was different from anything that had existed before. An entirely new concept, a new regime even, had been created and was completely regulated by international law. Therefore, South Africa could not claim any rights because of some other, earlier private law concepts of a mandate. Also, the Court noted that South Africa's authority was based on the mandate. Therefore, if the mandate lapsed, the authority of South Africa would lapse as well. ${ }^{54}$

The Court found that based on the mandate, South Africa had obligations directly relating to the administration of the mandate and obligations relating to the duty to submit to the supervision of the League. Obligations relating to the administration of the mandate the Court described as both general and particular. The general obligations meant that the mandatory had to promote the material

52 International Status of South West Africa, International Court of Justice, Advisory Opinion of 11 July, 1950, 131.

53 International Status of South West Africa (1950), 132.

${ }^{54}$ International Status of South West Africa (1950), 133. 
and moral well-being and the social progress of the inhabitants of the mandated territory. The source of these obligations was both in the Covenant of the League of Nations (Art. 22) and in the individual Mandate of South West Africa (Art. 25). The particular obligations had been called "guarantees" during the League period and included, for example, prohibition of the slave trade, limits on forced labour, freedom of conscience and religion, and the rights of missionaries. ${ }^{55}$ The Court also noted that the counterpart to such obligations was the right of the population to have the territory administered in accordance with these obligations. 56

In the Court's view, these obligations were the purpose of the entire existence of the mandate, "the essence of the sacred trust of civilisation". ${ }^{57}$ For this reason, their fulfilment did not depend on the existence of the League. Moreover, the Court concluded that this finding was emphasized by the intention of the drafters of the UN Charter to "safeguard the rights of States and peoples under all circumstances and in all respects, until each territory should be placed under the Trusteeship System". ${ }^{88}$ Also, South Africa had declared that it would continue to administer territory according to the obligations of the mandate (until the moment when the territory would be recognized as an integral part of the Union of South Africa). ${ }^{59}$

The second group of obligations were those relating to the duty to submit to the supervision and control of the League, including the rendering of reports to the League Council. ${ }^{0}$ As with other duties, the Court found that the necessity for supervision continued to exist even when the organs formerly responsible for the supervision disappeared. Also, the United Nations had an organ performing similar functions that could be used for this purpose. ${ }^{61}$ The Court also believed that the intention of the drafters of Article $80^{62}$ of the United Nations Charter must have been to provide for supervision in order to ensure the real protection of the rights of mandated territories. ${ }^{63}$ Supervision also included the receiving of

\footnotetext{
55 Ibid.

56 Ibid.

57 Ibid.

58 Ibid., 134.

${ }^{59}$ Ibid., 134-135.

60 Ibid., 136.

61 Ibid.
}

62 "1. Except as may be agreed upon in individual trusteeship agreements, made under Articles 77, 79, and 81, placing each territory under the trusteeship system, and until such agreements have been concluded, nothing in this Chapter shall be construed in or of itself to alter in any manner the rights whatsoever of any states or any peoples or the terms of existing international instruments to which Members of the United Nations may respectively be parties.

2. Paragraph 1 of this Article shall not be interpreted as giving grounds for delay or postponement of the negotiation and conclusion of agreements for placing mandated and other territories under the trusteeship system as provided for in Article 77."

${ }^{63}$ International Status of South West Africa (1950), 136-137. 
petitions from the mandates. ${ }^{64}$ As General Assembly resolutions on the former mandates presupposed that the United Nations took over supervisory functions ${ }^{65}$ and the General Assembly would have sufficient competence to do this, the Court declared the General Assembly legally qualified to exercise supervisory functions and South Africa to be under obligation to submit to supervision. ${ }^{66}$

The next question was whether the provisions of Chapter XII of the Charter (on International Trusteeships) were applicable and, if so, in what manner, to the Territory of South-West Africa? Was there an obligation to place the mandate under trusteeship? The Court answered no. In the Court's view, Articles $75^{67}$ and $77^{68}$ of the United Nations Charter would have been worded explicitly if such an obligation had been intended. ${ }^{6} 9$

Finally, the General Assembly asked whether the Union of South Africa had the competence to modify the international status of the territory of South West Africa, or, in the event of a negative reply, where the competence rested to determine and modify the international status of the territory. As the Court had noted earlier in its decision, the territory of South West Africa had an international status and was regulated by international rules. Also, according to the mandate itself (Art. 7) "[t]he consent of the Council of the League is required for any modification of the terms of the present mandate". Therefore, South Africa did not have the competence to modify the international status of the territory by itself. The Court concluded that as the organ mentioned in Article 7, the Council of the League of Nations, was the same as was responsible for the supervision of the mandate, it was natural that the organ responsible for the supervision of the mandate in the United Nations, the General Assembly, would be responsible for the modification of the mandate. Moreover, the General Assembly approved amendments to the trusteeships, and therefore, by analogy, would be the competent organ to approve amendments to mandates as well.

The terminology used by the Court in describing the mandates and the duties relating to them derived from the League period. This was even more emphasized in the dissenting opinion of Judge Alvarez, who noted that South Africa had in its hands, not just any territory, but a sacred trust of civilization. ${ }^{70}$ South Africa's task

\footnotetext{
${ }^{64}$ Ibid., 138.

${ }^{65}$ See e.g. General Assembly Resolution 141 (II) of 1 November, 1947.

${ }^{66}$ International Status of South West Africa (1950), 137.

${ }_{67}$ "The United Nations shall establish under its authority an international trusteeship system for the administration and supervision of such territories as may be placed thereunder by subsequent individual agreements. These territories are hereinafter referred to as trust territories."

68 "The trusteeship system shall apply to such territories in the following categories as may be placed thereunder by means of trusteeship agreements: a. territories now held under mandate; [...]." (Emphasis added.)

${ }^{69}$ International Status of South West Africa (1950), 139.

${ }^{70}$ Emphasis added.
} 
was "honorific", "disinterested" and "for the benefit of certain populations". ${ }^{71}$ Alvarez believed it was entirely possible that the local populations of South West Africa would never reach such a level of civilization that it could administer itself "without a protector or a guide". ${ }^{72}$

In his separate opinion, Judge Read, while emphasizing the importance of South Africa's duties and the rights of the inhabitants, did not elaborate on the more particular content of them but noted that they are mainly found in Article 22 of the League Covenant. ${ }^{73}$ The case shows that the Second World War had changed very little for the mandates. As the Court based its decision on League documents, it continued to use the same language as had been used in the League period. This language had its origins in the establishment of the mandates and had been developed in the numerous sessions of the Permanent Mandates Commission. ${ }^{74}$ It was still common to all parties with the only difference that the international community was now represented by the United Nations, not the League of Nations. ${ }^{75}$

The interpretation of the Court was thus very much along the lines of the original intent of the mandates system. However, it is clear that the Court emphasized how the UN was to continue as the supervisor of the mandate and as such, opened the door to the emphasis that the UN would in all its actions place on human rights. The second main change was the setting up of the trusteeship system in which self-determination and human rights were explicit aims. Though the Court rejected the possibility that the trusteeship rules should apply to the mandate of South West Africa without the approval of South Africa, these would become the standards upon which the sacred trust would in the coming cases be evaluated.

\subsection{The Persistent Objector to Human Rights: The South West Africa Cases of 1962 and 1966}

The issue of South West Africa had been discussed at length in the UN after the 1950 advisory opinion, but the legal development continued only in the 1960s, when Ethiopia and Liberia sent their applications to the Court. ${ }^{76}$ In these

\footnotetext{
${ }^{71}$ International Status of South West Africa (1950), Dissenting opinion of Judge Alvarez, 180.

72 Ibid., 183.

${ }^{73}$ International Status of South West Africa (1950), Separate opinion of Judge Read, 164-165.

${ }^{74}$ Pollock, 'The South West Africa Cases and the Jurisprudence of International Law', 773.

75 Ibid., 774.

76 The Court had considered issues relating to the mandate of South West Africa in two decisions, both relating to the interpretation of the 1950 opinion. In South-West Africa Voting Procedure (Advisory Opinion of 7 June, 1955: I.C.J. Reports 1955, 67), the General Assembly asked the Court the following question:
} 
applications, they brought the language of human rights to bear on the interpretation of the mandatories' obligations. Though they began their claims with the findings of the 1950 advisory opinion about the existence of the mandate and the obligations it brought, the violation of these obligations was seen as a violation of UN human rights standards.

\subsubsection{The Plea for Self-government}

In this section, I will first discuss the different ends, strategies and means of the parties to the case of South West Africa, i.e. Liberia and Ethiopia as applicants and South Africa as the respondent. I will then continue to explore how struggles between different regimes, especially between law and politics, morality and humanitarianism, can be seen in the case. ${ }^{77}$ Another struggle is between old and new approaches in international law, i.e. formalism and strong state sovereignty on the one side, and a teleological approach with support for human rights on the other.

The South West Africa cases of $1962^{78}$ and $1966^{79}$ were the result of repeatedly failed attempts to agree on the fate of South West Africa through UN procedures either in the General Assembly or the Security Council. Frustrated by the UN's inability to secure South West Africa a place outside the sovereignty of South Africa, Ethiopia and Liberia, the two African countries that had from early on been members of the League of Nations, attempted a solution through the Court. But the cases were not only about South West Africa. The cases were

"(a) Is the following rule on the voting procedure to be followed by the General Assembly a correct interpretation of the advisory opinion of the International Court Justice of 11 July, 1950:

"Decisions of the General Assembly on questions relating to reports and petitions concerning the Territory of South-West Africa shall be regarded as important questions within the meaning of Article 18, paragraph 2, of the Charter of the United Nations."'?

"(b) If this interpretation of the advisory opinion of the Court is not correct, what voting procedure should be followed by the General Assembly in taking decisions on questions relating to reports and petitions concerning the Territory of South-West Africa?"

The Court replied in the affirmative to question (a) and found no need to reply to question (b).

In the Admissibility of Hearings of Petitioners by the Committee on South West Africa (Advisory Opinion of 1 June, 1956: I.C.J. Reports 1956, 23), the Court was asked "Is it consistent with the advisory opinion of the International Court of Justice of 11 July, 1950 for the Committee on South West Africa, established by General Assembly resolution 749 A (VII) of 28 November 1953, to grant oral hearings to petitioners on matters relating to the Territory of South West Africa?". The Court replied that "it would not be inconsistent with its Opinion of 11 July, 1950 for the General Assembly to authorize a procedure for the grant of oral hearings by the Committee on South West Africa to petitioners who had already submitted written petitions".

77 See e.g. Pomerance, 'Case Analysis: The ICJ and South West Africa (Namibia): A Retrospective Legal/Political Assessment'.

${ }^{78}$ South West Africa Cases, Preliminary Objections (1962), 319.

${ }^{79}$ South West Africa, Second Phase (1966), 6. 
simultaneously a critique of apartheid in South Africa, and a plea for selfdetermination for former colonies and other dependent territories. The main motivation for referring the case of South West Africa to the ICJ was to have the Court review the legality of apartheid. Therefore, even though the actual case was about South West Africa, practices in South Africa were on trial as well. ${ }^{80}$ As the mandate of South West Africa included a clause (Art. 7) on taking conflicts on the interpretation of the mandates to the Court, the applicants believed this to be an effective route to condemn apartheid in South Africa as well. ${ }^{81}$ The applicants thought it would be easy to reach a judgement confirming their views. After all, the only thing that the Court needed to do was to confirm its decision from 1950.82 Also, apartheid had been condemned on several occasions by other organs of the UN, by both General Assembly and Security Council resolutions. ${ }^{83}$ Had the applicants succeeded, they would have enabled a legal judgement also on South Africa, South Africa being out of the reach of the Court. At the same time, the Court would have strengthened the norms of self-determination and nondiscrimination. ${ }^{84}$ On the other hand, South Africa believed that if other nations had more knowledge on apartheid, they would understand its importance. ${ }^{85}$ This time, however, the Court did not agree, but maintained that there was no legal way to reach what the applicants were asking for. According to the ICJ, the case was about politics, not law. There was yet no sufficient legal case to convince the Court of the necessity to declare that South West Africa had a right to decide on its own fate.

In 1961 Ethiopia and Liberia both sent identical applications, where they asked the Court to declare:

1. that South West Africa was still under a mandate and that the mandate was still a treaty in force,

2. that South Africa was bound by the obligations set by Article 22 of the League Covenant,

3. that the supervisory functions had been transferred from the League Council to the United Nations General Assembly,

4. that South Africa still had an obligation to submit petitions from the territory and reports,

${ }^{80}$ Landis, 'The South West Africa Cases: Remand to the United Nations', 633.

81 "The Mandatory agrees that, if any dispute whatever should arise between the Mandatory and another Member of the League of Nations relating to the interpretation or the application of the provisions of the Mandate, such dispute ... shall be submitted to the Permanent Court of International Justice..." Article 7, mandate of South West Africa (emphasis added).

82 Pomerance, The Advisory Function of the International Court in the League and UN Eras, 429.

${ }^{83}$ See e.g. General Assembly Resolution 395 (V) of 2 December, 1950, General Assembly Resolution 820 (IX) of 14 December, 1954, General Assembly Resolution 1178 (XII) of 26 November, 1957, Security Council Resolution 134 (1960) of 1 April, 1960.

${ }^{84}$ Pomerance, The Advisory Function of the International Court in the League and UN Eras, 429.

${ }_{85}$ D'Amato, 'Legal and Political Strategies of the South West Africa Litigation', 10. 
5. that South Africa had one-sidedly modified the terms of the mandate,

6. that South Africa failed to promote the well-being of the inhabitants of the territory,

7. that the practice of apartheid violates the mandate,

8. that South Africa violates South West Africa's right to self government and United Nations human rights standards.

The applications of Ethiopia and Liberia were thus clearly developed from the 1950 case but had distinct differences of approach.

In their written memorial of April 15, 1961 to the International Court of Justice, the applicants, Ethiopia and Liberia, used rights language in two ways. Firstly, they listed all the United Nations documents concerning the human rights situation in South West Africa. Secondly, they argued that the policy of apartheid violated the duty to take care of the well-being of the inhabitants as determined in Article 2 of the mandate and Article 22 of the Covenant.

In their interpretation of the foundation of the mandates, the concept of "sacred trust" and "tutelage", they came close to giving them a rights-based meaning: "Extension of these doctrines to international practice and principle reflected a maturing sense of international responsibility for the dignity and wellbeing of the individual person." 86 Later in their applications, the applicants gave a more explicit human rights-based reading of Article 2 of the mandate and Article 22 of the League Covenant combined: "[The Union] may not subjugate the majority of the inhabitants of the Territory in the interest of a minority. It may not act in disregard of human rights so basic and so fundamental that without them the rules of social intercourse must always be determined by force." ${ }^{77}$ They supported this reading with standards from Chapters XI, XII and XIII on trusteeships of the United Nations Charter, which according to them, offered guidance for the interpretation of the League of Nations documents and which South Africa had accepted when becoming a member of the United Nations. ${ }^{88}$ Thus, a concrete reference to human rights (Art. 76 of the United Nations Charter) also derived from such a combined reading of these articles. In essence, what the applicants were intending to claim was that in a charged situation and world, more recent norms ought to be taken into account to aid in the interpretation of the older norms (thus referring to teleology as an interpretational method). In the applicants' view, the discrimination of "native" inhabitants inherent in the policy of apartheid signified that the mandatory had not promoted "the material and moral well-being, the social progress and the development of the people of South West Africa", ${ }^{89}$ including also the "protection of basic human

86 South West Africa Cases, Preliminary Objections, Memorial Submitted by the Government of Ethiopia (15.4.1961), 36.

${ }^{87}$ Ibid., 104.

88 Ibid., 104.

${ }^{89}$ Ibid., 162. 
rights and fundamental freedoms of such persons". ${ }^{90}$ In their later observation they elaborated their ideas on the interpretation of the mandate, citing Hersch Lauterpacht, who had maintained that when making an interpretational decision between the national sovereignty of individual states and giving full effect to the purpose of the obligations at hand, the latter must prevail. ${ }^{91}$ Thus, as Article 7 of the mandate of South West Africa was "embodied in a humanitarian instrument" and the purpose of the mandates was the well-being and development of the inhabitants, the nature of the entire instrument was humanitarian. Therefore, all interpretation ought to serve the humanitarian aim. ${ }^{92}$ The rules of interpretation needed to be chosen in such a way that made the instrument serve its purpose most effectively. ${ }^{93}$

South Africa's reply was based on the lack of jurisdiction on account of Ethiopia and Liberia having no locus standi, meaning that they lacked a sufficient legal interest in the matter. For this they stated four reasons. Firstly, because of the dissolution of the League of Nations, the mandate for South West Africa was no longer a treaty in force; secondly, that neither Liberia nor Ethiopia were "another Member of the League of Nations", as was required by Article 7 of the mandate for South West Africa; thirdly, there was no legal "dispute between Liberia and Ethiopia on the one hand and South Africa on the other hand, particularly because the first mentioned states lacked material interest in South Africa's view; and fourthly, the issue was not a "dispute" which "cannot be settled by negotiation" as was required by Article 7 of the mandate for South West Africa. South Africa later amended the first part of their submissions, maintaining that the mandate for South West Africa had never been a "treaty or convention in force", as was required by Article 37 of the Statute of the Court. ${ }^{94}$

While South Africa was not making rights claims, it did answer some of the rights-based claims of the applicants. Most importantly, it claimed that the South African administration in South West Africa did not affect the aim of the mandate as a "sacred trust" in any way. On the contrary, it claimed that a closer connection with South Africa and the benefits of a larger community was actually in the best interests of the natives of South West Africa. ${ }^{55}$ South Africa gave assurances that it continued to administer the territory "in the spirit of the mandate", observing

\footnotetext{
${ }^{90}$ Ibid., 164-165.

${ }^{91}$ South West Africa Cases, Preliminary Objections, Observations of the Governments of Ethiopia and Liberia (1 March, 1962), 476.

92 Ibid.

${ }^{93}$ Ibid., 475.

${ }^{94}$ South West Africa Cases, Preliminary Objections (1962), 327.

${ }^{95}$ South West Africa Cases, Preliminary Objections (1962), Preliminary Objections filed by the Government of the Republic of South Africa (30 November, 1961), 234, 257, 259.
} 
the "sacred trust". ${ }^{96}$ In South Africa's view, it was also the wish of the inhabitants of South West Africa to be incorporated into South Africa. ${ }^{97}$

On the other hand, South Africa denied that even if international law did provide some rights to individuals, South Africa would have to have consented to such rights in order to be bound by them. It stated that "there is nothing to indicate that rights in International Law vis-à-vio the Mandatories were intended to be conferred upon them". ${ }^{98}$ In concrete issues relating to mandates, this applied to the right to petitions as well, as there was no agreement or provisions on them in the mandatory agreements. ${ }^{99}$ Also, such a "right" would have been dependent on a supervisory body, and after the cessation of the League of Nations there was none. ${ }^{100}$ South Africa found no need to answer whether "sacred trust" or "tutelage" fell within the realm of international law, domestic law or morality, as the mandate, and thus, any possible obligations relating to it, had ceased to exist. ${ }^{101}$

In its resolution, the ICJ described the essential principles of the mandates system in a more or less similar way as they had in 1950, only worded in slightly broader terms. According to the Court, the principles included the recognition of certain rights of the peoples of underdeveloped territories, a regime of tutelage for such peoples, "a sacred trust of civilisation", the object of such a trust being to promote the well-being and development of the peoples in the territories, fortified by safeguards for the protection of the rights of such peoples. ${ }^{102}$

South Africa's first objection had been that the mandate for South West Africa "has never been, or at any rate is since the dissolution of the League of Nations no longer, a 'treaty or convention in force' within the meaning of Article 37 of the Statute of the Court... ." 103 The Court, however, concluded that the mandate was a treaty, because it "in fact and in law, is an international agreement having the character of a treaty or convention". As proof, the Court mentioned the preamble of the mandate. In the preamble, "the Principal Allied and Associated Powers agreed to confer the mandate upon His Britannic Majesty to be exercised on his behalf by the Government of the Union of South Africa ... in the following terms ... with the following provisions ...". ${ }^{104}$ However, the Court emphasized the

\footnotetext{
96 Ibid., 268.

${ }^{97}$ Ibid., 259-261.

${ }^{98}$ Ibid., 358.

99 Ibid.

${ }^{100}$ Ibid., 359.

101 Ibid., 359.

${ }^{102}$ South West Africa Cases, Preliminary Objections (1962), 329.

103 South West Africa Cases, Preliminary Objections (1962), 327. Article 37 of the Statute: "Whenever a treaty or convention in force provides for reference of a matter to a tribunal to have been instituted by the League of Nations, or to the Permanent Court of International Justice, the matter shall, as between the parties to the present Statute, be referred to the International Court of Justice."

${ }^{104}$ Mandate for German South West Africa, preamble.
} 
distinctiveness of the mandate as a legal instrument, declaring it a "special type of instrument" and a "novel international regime". 105

South Africa claimed that even if there once had been a treaty, it was not in force after the League of Nations was dissolved. The Court denied the mode of thought of South Africa relying on similar argumentation than it had done twelve years earlier. The Court pointed out that there were two types of obligations relating to the mandate, those relating to the actual administration of the territory and those relating to the mandatory's duty to report and to be subject to supervision and the entire machinery of implementation. South Africa admitted the existence of the first type of obligations but denied the existence of the latter. With the outcome of the Advisory opinion of 1950 in mind, the Court noted that " $[\mathrm{t}]$ o exclude the obligation connected with the Mandate would be to exclude the very essence of the Mandate". 106

In its second objection, South Africa claimed that Liberia and Ethiopia were not "another Member of the League of Nations", as was demanded by paragraph 2 of Article 7 of the mandate of South West Africa. ${ }^{107}$ South Africa maintained that as the League had been dissolved, there could no longer be any members and thus the applicants could not bring a case to the Court as "another Member of the League". Again, the Court disagreed. It noted that judicial protection was an essential feature of the "sacred trust". There had been several organs in the League of Nations to ensure the performance of the trust, including the Council, the Assembly, the Permanent Mandates Commission and the member states, each with their own roles. Rules of unanimity were in place in the Council, and as mandatory states were also members of the Council, it was necessary to give a role to other member states as well, in order to ensure protection in a situation where a mandatory state would vote against a certain measure: "[G]ranting all members an access to the Court would secure the supervision of the mandate." 108 At the time of the dissolution of the League, all members of the League agreed to continue the different mandates by also maintaining the rights of the League members. ${ }^{109}$ Therefore, members of the former League would continue to have the right to invoke the compulsory jurisdiction of the Court, as they had had before the dissolution of the League. ${ }^{110}$ Also, South Africa has accepted the fact that its obligations concerning the mandate would continue to exist, which the Court

\footnotetext{
${ }^{105}$ South West Africa Cases, Preliminary Objections (1962), 331.

${ }^{106}$ South West Africa Cases, Preliminary Objections (1962), 334.

107 "The Mandatory agrees that, if any dispute whatever should arise between the Mandatory and another Member of the League of Nations relating to the interpretation or the application of the provisions of the Mandate, such dispute, if it cannot be settled by negotiation, shall be submitted to the Permanent Court of International Justice provided for by Article 14 of the Covenant of the League of Nations." Mandate for German SouthWest Africa, Article 7, paragraph 2.

108 South West Africa Cases, Preliminary Objections (1962), 337.

109 Ibid., 338.

110 Ibid.
} 
interpreted to include its obligations under Article 7 of the mandate. ${ }^{111}$ Finally, the Court found that it was necessary to take into consideration the circumstances in interpreting "another Member of the League". "Literal objections are not meaningful," it said. ${ }^{112}$

South Africa's third objection was that the dispute was not a dispute in the meaning of Article 7 of the mandate. South Africa maintained that the "generally accepted meaning" of a compulsory jurisdiction clause would be "a disagreement or conflict between the Mandatory and another Member of the League concerning the legal right and interests of such other Member in the matter before the Court". However, the Court did not make any distinctions between the rights of individual League members and other rights relating to the mandate. (This interpretation would eventually change in the Court's decision four years later.) Rather, the Court found that the compulsory jurisdiction could be invoked to protect both the material interests of the League members or their nationals, or the well-being and development of their inhabitants. ${ }^{113}$

In its final objection South Africa pointed out that Article 7 of the mandate required that such a dispute could not be settled by negotiation. As several negotiations on the position of South West Africa had been ongoing in different organs of the United Nations, the Court found it unlikely that any further negotiation would lead to a settlement. ${ }^{114}$ The Court thus dismissed all South Africa's preliminary objections.

The 1962 decision on the preliminary objections had proved to be promising from the applicant's point of view. The Court had clearly denied all of South Africa's arguments, and it was now to be expected that the Court would move on to the merits of the case. ${ }^{115}$ The Court had accepted, based on the decision made in 1950, that the mandate was still in force and that South Africa was responsible for the well-being and the development of the inhabitants of South West Africa. Moreover, the Court accepted that the jurisdictional clause in Article 7 of the mandate was sufficient to grant Ethiopia and Liberia a legal interest to bring South Africa's alleged violations of the mandate to the Court. The Court stressed that Article 7 applied similarly to questions relating to the well-being and development of the inhabitants as it did to disputes concerning material interests of nationals of the applicant states. ${ }^{116}$ Before the Court's 1966 decision, it was generally believed that the members of the League of Nations could bring disputes concerning the mandates to the PCIJ in all cases where diplomatic means were

\footnotetext{
111 Ibid., 340.

112 Ibid., 341.

113 Ibid., 344.

114 Ibid., 346.

115 Gross, 'The South West Africa Case: What Happened?', 44.

${ }^{116}$ South West Africa Cases, Preliminary Objections (1962), 344.
} 
not sufficient. This would include any situation where the mandatory had violated its duties towards the inhabitants of the mandated territory. ${ }^{117}$

The lengthy joint dissenting opinion of Sir Percy Spender and Sir Gerald Fitzmaurice would anticipate the turn that the South West Africa case would take in its second phase. Spender and Fitzmaurice criticized the fact that the majority opinion was not based on legal reasoning. In their view the majority had submitted the "various considerations of a non-juridical character", such as "social, humanitarian and other", which they had not, however, specified.118 Their own approach, apparent in the second phase a few years later, can be summed up in their own words: "They [i.e. non-juridical considerations] cannot be allowed to deflect us from our duty of reaching a conclusion strictly on the basis of what we believe to be the correct legal view."119 These two dissenting judges believed that the matter that would need to be decided in the merits phases was of such a loaded nature that it was crucial that everything would require objective definitions in order to be decided in legal terms. ${ }^{120}$ They believed, moreover, that where sufficient objectivity could not be reached with the issues at hand (the well-being of a certain population and other humanitarian concerns), a judicial court was not the right forum for such decisions. "Progress" and "well-being" were subjective concepts open to various interpretations. They could not be defined in an objective manner, and because of the values behind them, they were better suited for a political organ. ${ }^{121}$ Spender and Fitzmaurice accused both the applicants and the Court of applying a "principle of hindsight" and "some doctrine of "subsequent necessity' quite unknown to international law". They also claimed that a provision, unimportant in the original mandatory system (i.e. Art. 7 of the mandate of South West Africa), was used purposefully because of "recent events", meaning a political agenda of advancing self-determination in former colonies and in South West Africa. ${ }^{122}$ According to the two judges, this was "understandable, but it is not a valid legal argument". ${ }^{123}$ Yet, according to them both, the case should not proceed to the merits phase. They agreed with the preliminary objections of the respondent, as they would later in the 1967 decision as well. Their main

117 Quincy Wright interpreted the possibility to invoke an international legal process to give strong rights to League members concerning their own interests, but also for the protection of interests of the inhabitants of the mandates. Wright, Mandates under the League of Nations, 475. See also Gross, 'The South West Africa Case: What Happened?', 46; Falk, 'The South West Africa Cases: The Limits of Adjudication', 5; Landis, 'The South West Africa Cases: Remand to the United Nations', 654, fn 164.

118 South West Africa Cases, Preliminary Objections (1962), Joint dissenting opinion of Sir Percy Spender and Sir Gerald Fitzmaurice, 466.

119 Ibid., 466.

${ }^{120}$ Ibid., 466.

121 Merrills, Judge Sir Gerald Fitzmaurice and the Discipline of International Law, 41.

${ }^{122}$ South West Africa Cases, Preliminary Objections (1962), Joint dissenting opinion of Sir Percy Spender and Sir Gerald Fitzmaurice, 521.

123 Ibid. 
arguments were that the mandate was not a treaty, but rather an act of an organ of an international organization and was thus not in force as a treaty; ${ }^{124}$ that the applicants did not have a legal basis to invoke Article 7 of the mandate of South West Africa; ${ }^{125}$ that there was no dispute between the applicants and the respondent; ${ }^{126}$ and even if there had been a dispute, it was not one that could be settled by negotiation, as Article 7 would have required. ${ }^{127}$

The applicants' victory in the 1962 case was only a temporary one, since the ICJ had only discussed the preliminary objections of South Africa. In preparation for the merits of the case, the applicants started to modify their arguments gradually, emphasizing the discriminatory nature of apartheid. They maintained that international standards or an international norm of non-discrimination existed which would grant the Court a legal avenue to judge the actions of South Africa in South West Africa, particularly the practice of apartheid. ${ }^{128}$ Their optimism proved to be misguided. What they did not anticipate was the changes in the composition of the Court that would result in it taking a completely opposite approach, one formulated largely by Fitzmaurice and others sharing his formalist way of thinking.

In the applicants' view, as apartheid was a discriminatory practice it violated Article 2 of the mandate, promoting "to the utmost the material and moral wellbeing and social progress of the inhabitants". ${ }^{129}$ Moreover, in the application the applicants maintained that South African regulations suppressed the rights and liberties of the inhabitants in their way towards self-government. According to the applicants, such rights and liberties could be found implicitly in the Covenant of the League of Nations, the terms of the mandate, and were currently accepted as "legal standards", to be found in the Charter of the United Nations and the Universal Declaration of Human Rights. ${ }^{130}$ In the oral proceedings, the applicants proposed an even stronger norm to support their claim of South Africa violating the mandate, namely that the mentioned rights and liberties of the inhabitants of the mandate were not only "legal standards", but possibly an "international legal norm, or both". ${ }^{131}$

South Africa, on the other hand, maintained that if it was still bound by the mandate, it had not given its consent to any changes in the terms of the mandate and thus would not accept any meanings that did not exist at the time of the drafting of the mandate. South Africa relied on its statement that the whole

\footnotetext{
124 Ibid., 503.

125 Ibid., 546.

126 Ibid., 560.

127 Ibid., 563.

128 Landis, 'The South West Africa Cases: Remand to the United Nations', 640-641;

South West Africa, Second Phase (1966), 15.

${ }^{129}$ Ibid., 641; South West Africa, Second Phase (1966), 15.

${ }^{130}$ General Assembly Resolution 217 A (III), 10 December, 1948.

${ }^{131}$ South West Africa, Second Phase (1966), 15.
} 
mandate had lapsed on the dissolution of the mandate, or, alternatively, that the respondent's obligations had lapsed upon the same event and had not been replaced by other obligations. South Africa also denied having violated its Article 22 obligations. ${ }^{132}$

\subsubsection{Human Rights as Law or Morality?}

The Court found the existence of the mandate to be a secondary question, to be addressed in the merits phase of the proceedings if the case ever went so far. ${ }^{133}$ From the Court's point of view, the main question was whether Ethiopia and Liberia had sufficient legal interest in South Africa's actions in South West Africa in order to proceed to the merits of the case. Thus, despite denying South Africa's preliminary objections in 1962, the Court noted that the question of jurisdiction was still to be resolved.

In viewing whether the applicants had a sufficient legal interest in the case, the Court looked into the provisions of the mandates, finding two different kinds of obligations written in them. The first type the Court called "conduct" provisions. These were defined as the "articles defining the mandatory's powers, and its obligations in respect of the inhabitants of the territory and towards the League and its organs". ${ }^{134}$ Such obligations would include any conduct of the mandatory towards the inhabitants of the territory, including the mandatory's duty to ensure the "guarantees", for example the duty to abolish the slave trade, to guarantee fair labour conditions, etc.

The second type of obligations were "special interests", meaning rights related to the mandated territory that individual members of the League of Nations could claim in favour of their own nationals. ${ }^{135}$ The Court found there to be numerous such rights in the $\mathrm{A}$ and $\mathrm{B}$ mandates relating to commerce, establishment and navigation, and to be found in treaties between the states. However, the Court concluded that in the C mandates the only "special interests" provisions were those on the freedom of missionaries to enter into, travel and reside in the mandated territories.

The Court found the dispute to be only related to the former, the "conduct" provisions and formulated the question thus: "whether the various mandatories had any direct obligation towards the other members of the League individually, as regards the carrying out of the 'conduct' provisions of the mandates". ${ }^{136}$

In its resolution the Court reversed its earlier ruling with a jurisdictional resolution, effectively bringing the case to a close. The change of heart had much to do with the changes in its composition. The election of new members and the

\footnotetext{
132 South West Africa, Second Phase (1966), 16-17.

${ }^{133}$ South West Africa, Second Phase (1966), 19, para. 7.

${ }^{134}$ South West Africa, Second Phase (1966), 20, para 11.

${ }^{135}$ South West Africa, Second Phase (1966), 20, para. 32.

${ }^{136}$ South West Africa, Second Phase (1966), 22, para. 14.
} 
unexpected absence of some of the members (due to disqualification, illness and death), and the election of Spender as President, resulted in the formalists gaining a 7-7 tie with the vote of the President being decisive. ${ }^{137}$ The dissenters of 1962 now formed the majority opinion. The Court did not find Liberia or Ethiopia to have a sufficient legal interest to bring the matter to the Court. According to the Court, the mere existence of a "sacred trust" was not sufficient to result in a legal right or interest. The Court emphasized that the tutelage of the inhabitants of the mandates was exercised on behalf of the League, not in the capacity of individual states. Also, the mandatories were trustees for the League, not for its individual members. ${ }^{138}$ The Court emphasized the importance of using the period of establishment of the mandates system as the starting point, i.e. looking at the drafters' intentions in the interpretation of the mandate. ${ }^{139}$ The setting of that particular period would give the content to the various mandate instruments and therefore reveal the juridical meaning of the "sacred trust of civilization". ${ }^{140}$ The Court argued that individual League members had no role in the supervision of the mandates, but the mandatories needed to satisfy the League Council with their reports. ${ }^{141}$ Thus, the mere membership in the organization was not sufficient to derive rights relating to mandates to individual members. ${ }^{142}$ The Court found that in order for any individual rights to exist, they should be clearly written into a legal text or instrument, which had not been the case. ${ }^{143}$

Thus, the "sacred trust" did not form a "legal interest" for the League members. Instead, the Court declared "sacred trust" to be a moral ideal. ${ }^{144}$ The Court could take into consideration moral ideals only to the extent that they were formulated in a legal format. The Court noted that throughout the case there had been suggestions that "humanitarian considerations" would have sufficient legal validity that the Court should take them into account in its decision. They concluded: "The Court does not think so. It is a court of law, and can take account of moral principles only in so far as these are given a sufficient expression in legal form. Law exists, it is said, to serve a social need; but precisely for that reason it can do so only through and within the limits of its own discipline. Otherwise, it is not a legal service that would be rendered." ${ }^{145}$ The role of such "humanitarian considerations" was to act as an "inspirational basis" for drafting legal rules. Therefore, the role of the preamble of the UN Charter, including its human rights

137 Falk, 'The South West Africa Cases: An Appraisal', 11; Reisman, 'Revision of the South West Africa Cases', 41; Higgins, 'The International Court and South West Africa: The Implications of the Judgement', 586-587.

${ }^{138}$ South West Africa, Second Phase (1966), 24, para. 20.

${ }^{139}$ South West Africa, Second Phase (1966), 23, para. 16.

${ }^{140}$ South West Africa, Second Phase (1966), 23, para. 17.

${ }^{141}$ South West Africa, Second Phase (1966), 25, para. 23.

${ }^{142}$ South West Africa, Second Phase (1966), 25-26, para. 25.

${ }^{143}$ South West Africa, Second Phase (1966), 32, para. 44.

${ }^{144}$ South West Africa, Second Phase (1966), 34, para. 51.

${ }^{145}$ South West Africa, Second Phase (1966), 34, para. 49. 
references (“... to reaffirm faith in fundamental human rights, in the dignity and worth of the human person, in the equal rights of men and women and of nations large and small...") 146 "constitute the moral and political basis for the specific provisions thereafter set out". ${ }^{147}$ If such moral ideals were to be thought of as legal rights and obligations, they would have to be formulated in a legal form, such as the trusteeship system or the UN Charter Chapter XI on non-self-governing territories. ${ }^{148}$

Thus, the Court would not answer whether a right to equal treatment (if such a right existed) and apartheid were in contradiction with each other. Did such an international norm exist through which one could determine whether there was a right to equal treatment? Would it have been possible for such a right to be included in the "sacred trust"?

\subsubsection{Judge Fitzmaurice, the Formalist Jurist}

The turn towards a strict formalistic argumentation and the legalism behind it was presumably the work of judges Spender and Fitzmaurice, who had expressed similar views in their earlier dissent. They rejected the teleological argumentation that would have taken into account later changes in the circumstances, such as the rise of the decolonization and human rights movements. According to Fitzmaurice, the unilateral revocation of the mandate was in contradiction to the fact that the $\mathrm{C}$ mandates were close to the sovereignty of the mandatory and that these would never have accepted the unilateral revocation of the mandates. The way he interpreted treaties was an example of the strictest version of textual interpretation, where the intentions of the parties was the main aid if the text itself could not provide an answer. In the case of the mandates, the text of the agreements was the starting point, and it was to be interpreted in its context, that is, according to the travaux préparatoires, indicating the original intent of the parties.

An important issue for Fitzmaurice was the question of propriety. In his view, the court could not make a decision that would endanger its neutral position as a court of law. A court ought to examine its decision making, taking into account whether an intended decision was compatible with its status as a court of law. Propriety safeguards the integrity of a court so that it does not become subordinated to political actors. In the South West Africa cases, Fitzmaurice believed that the intention of the applicants and the forces behind them was to use the court as a means to a political end, namely the independence of Namibia. ${ }^{149}$

The originalist interpretation of the mandates first presented by Spender and Fitzmaurice and later continued by Fitzmaurice demonstrated how much political relevance could a purely formal legal argument have. To their critics, the

\footnotetext{
146 United Nations Charter, preamble.

147 South West Africa, Second Phase (1966), 34, para. 50.

148 South West Africa, Second Phase (1966), 34, para. 51.

149 Merrills, Judge Sir Gerald Fitzmaurice and the Discipline of International Law, 38-40.
} 
formalistic argument appeared to be conservative, favouring colonialism. For those who wanted to change the world for the better, claims that one should follow the original intent of the 1920s were hopelessly backwards. The strict separation of law, politics and morality as argued by Fitzmaurice were seen as judicial conservatism. ${ }^{150}$

\subsubsection{Judges Jessup and Tanaka and the Critique of Formalism}

The President of the Court, Judge Spender, whose vote had been decisive in the outcome ${ }^{151}$ wrote that it was not the duty of the court to start speculating what the outcome would have been if the case had continued to the merits phase: “...it would hardly be justifiable for such a judge [in a separate opinion] to proceed further into the merits, expressing his views on how he thinks the Court should or would have pronounced upon the whole complex of questions centering around different provisions of the Mandates ... had the Court not reached the decision it actually did." 152 Many of the judges, however, did think that that was the duty of the Court.

Had the case proceeded to the merits phase, the Court would have needed to decide what legal duties the mandates treaty would have provided and how they were to be interpreted. Would they have had the content that they had during the time of their drafting? Or should the Court have taken into account the standards that existed at the time of the judgment? South Africa naturally agreed on the former interpretation, believing that the only standards according to which the Court could have acted were those that were set by the League of Nations in 1920. The latter standards would have included questions such as human rights, the problems caused by apartheid, and so on. The applicants believed that this was the starting point of interpretation, but did not give a more detailed account of what they considered the relevant rights were. They believed, however, that the mandate was a "constitutional type of document", evolving over the years. ${ }^{153}$ In his dissenting opinion Jessup also emphasized the importance of changing values in the determination of a legal meaning to well-being: "The law can never be oblivious to the changes in life, circumstance and community standards in which it functions." 154

Of course, had the Court come to such a conclusion, it would have needed to determine the rights that South Africa would have violated. What (human) rights would have been applicable at the time of the court's proceedings? As South Africa consented to none, did such rights have a sufficient customary basis in

150 Falk, 'The South West Africa Cases: An Appraisal', 7; Berhardt, 'Homogenität, Kontinuität und Dissonanzen', 34-35.

151 The votes were 7 to 7 , Spender's being decisive.

${ }^{152}$ South West Africa, Second Phase (1966), Declaration of President Sir Percy Spender, 51, para. 28.

${ }^{153}$ Landis, 'The South West Africa Cases: Remand to the United Nations', 643.

${ }^{154}$ South West Africa, Second Phase (1966), Dissenting opinion of Judge Jessup, 439. 
1966? Judge Jessup concluded that they did. Both the existence of the "norm" and the "standard", as claimed by the applicants, would have prohibited "official government allocation of status, rights, duties and privileges upon the basis of membership of a group, class or race, without regard to individual merits, capacity or quality". ${ }^{155}$ Therefore, the applicants believed that apartheid violated Article 2 of the mandate as a matter of law, giving the court a legal standard to assess the actions of South Africa in South West Africa. ${ }^{156}$

The applicants demanded that the Court determine that either a norm or a legal standard prohibiting discrimination existed. The case was novel in that the prohibition of discrimination or other (human) rights had hardly existed in international legal cases, or been implemented in many national courts. ${ }^{157}$ Basing its decisions on procedural and technical reasoning, the court avoided commenting at all on apartheid in South Africa, which was quite internationally known at the time. The Court distanced itself from the rights language and took a formalistic approach to the question. Throughout the decision, examples can be found of how the Court differentiated between the moral and the legal, stressing its own task in safeguarding the legal. The vocabulary of rights was not yet used by the majority of the Court members, but was still seen as a political and moral vocabulary. The majority in the decision was slight and the decision was made by the President's vote. Even so, in the dissenting opinions of the minority the (human) rights of the inhabitants of the mandates were rarely mentioned. The dissenters, however, did often mention humanitarianism in connection with the mandates, but this came close to the wording of the majority. Of course, because of the president's warning, it is possible that some dissenting judges refrained from commenting on the possible outcome of the merits. But it is also possible that the judges believed that (human) rights were not applicable as a law or an explicit treaty did not exist and there was no such customary law that South Africa had consented to. Thus, a sufficient consensus on such values did not exist in order for them to become part of international law and as such, applicable by the Court. 158

The two exceptions were the dissenting Judges Jessup and Tanaka, who differed from each other in their reasoning, although both came to the conclusion that human rights were applicable in the case. Both of them believed that the purpose of the mandates, both "moral well-being" and "social progress", should be interpreted according to the values that prevailed at the time of the court's decision, as standards had changed from the time of the drafting of the mandates.

Jessup believed that legal processes to protect human rights were relevant when determining the duties relating to "sacred trust". He believed that human rights were a source of interpretation, not a binding legal norm as such. In finding

\footnotetext{
${ }^{155}$ Landis, 'The South West Africa Cases: Remand to the United Nations', 642.

156 Ibid., 644.

157 Ibid., 640.

${ }^{158}$ Falk, 'The South West Africa Cases: An Appraisal', 15.
} 
such standards, the United Nations acted as one possible source: "The virtually universally accepted description of other legal characteristics of this actual modern world is written in the Charter of the United Nations." 159 Thus, the issue was not only political or humanitarian, but also justiciable. He maintained that standards of administration and values had changed from the 1920s. There was no binding norm through which the Court could have directly applied human rights to the mandate of South West Africa. Changing standards, however, affected the ways the Court should interpret the mandate agreement. Therefore, the agreement should be interpreted in a manner that favoured human rights, meaning that South Africa should take the human rights of the inhabitants into consideration in its administration. Such a standard would help in determining whether South Africa had violated the duties of the mandatory. In Jessup's opinion: “The law abounds in examples of standards or criteria, which are applied by courts as tests of human conduct." 160

Tanaka's evaluation was much more radical. He believed that South Africa could not continue to be a persistent objector to human rights, preventing their application. In his view, the mandate had received a new content through the law that had developed after the Second World War, as values had changed. Tanaka maintained that human rights were independent of such treaties, where they were formulated. Human rights had always existed, independent of states and ideologies. They merely existed, as a natural law of sorts and as higher values, as a kind of a secular religion, without the limitations of earthly laws. Of course, such rights would require a certain concreteness in order for the Court to be able to apply them. Tanaka believed the mandate to be a legal relation and means to a humanitarian end. ${ }^{161}$ In his view, the only relevant relation was that between the administration and those administered. ${ }^{162}$ But as material and moral well-being was political by nature, they could not be determined in a legal manner. Thus, what was needed was a (legal) agreement that renders legal the political and moral. The administrator had the possibility to choose how it acts in order to achieve its goal. There was, however, a legal limit to his freedom to decide, and this limit was the norm/standard whose existence was claimed by the applicants. Thus, the mandate had aims that were social and moral by nature and the respondent had a duty to fulfil them. South Africa could do this according to its choice, only limited by the norm/standard of non-discrimination. As the means of choice of the respondent was apartheid, the legal limitation had to be applied, as apartheid was against the norm/standard.163 Tanaka maintained that the UN

\footnotetext{
${ }^{159}$ South West Africa, Second Phase (1966), Dissenting opinion of Judge Jessup, 440. ${ }^{160}$ South West Africa, Second Phase (1966), Dissenting opinion of Judge Jessup, 434. ${ }^{161}$ South West Africa, Second Phase (1966), Dissenting opinion of Judge Tanaka, 265. 162 South West Africa, Second Phase (1966), Dissenting opinion of Judge Tanaka, 267, $270,271$.

163 South West Africa, Second Phase (1966), Dissenting opinion of Judge Tanaka, 281286.
} 
Charter was relevant for finding a norm of non-discrimination. There was no definition nor any other guidance for the application of such a right in the Charter. Tanaka found that the right was not binding because of the Charter, but that the norms in the Charter were binding without them to be drafted as such. Tanaka listed all the instruments where apartheid was denounced, and concluded that the right to non-discrimination was international customary law. ${ }^{164}$ This was supported by the fact that such laws existed in almost all national legal systems. ${ }^{165}$ Moreover, the rights to non-discrimination and human rights were not only customary, but in his view ius cogens:166 "Human rights which require protection are the same; they are not the product of a particular juridical system in the hierarchy of the legal order, but the same human rights must be recognized, respected and protected everywhere man goes." ${ }^{167}$ Tanaka found that natural law and ius cogens related to each other, although he acknowledged that referring to natural law might cause some critique. He lifted international general principles as an international legal source above other law, seeing it as natural law, which also bound those who denied its existence. Therefore, the principle of nondiscrimination was binding in the mandates because it existed in the constitutions of all "civilized states"; it was an international legal principle and, as such, natural law. ${ }^{168}$ Tanaka's argument was novel, especially as ius cogens was introduced in international law only in 1969 by the Vienna Convention on the Law of Treaties. ${ }^{169}$

\subsubsection{Disappointment}

Apartheid was not yet an issue discussed in the 1950 advisory opinion. In Ethiopia's and Liberia's application for the ICJ in 1962, the applicants noted that "the Union, [...] has practised apartheid [...]; that such practice is in violation of its obligations as stated in Article 2 of the Mandate and Article 22 of the Covenant of the League of Nations; and that the Union has the duty forthwith to cease the practice of apartheid in the Territory". ${ }^{170}$ By 1966 the applicants asked the Court to declare that there was an international norm or standard of non-discrimination or non-separation, and thus asked the Court to denounce South Africa's practice of apartheid.

\footnotetext{
${ }^{164}$ South West Africa, Second Phase (1966), Dissenting opinion of Judge Tanaka, 293. 165 South West Africa, Second Phase (1966), Dissenting opinion of Judge Tanaka, 295. ${ }^{166}$ South West Africa, Second Phase (1966), Dissenting opinion of Judge Tanaka, 296. 167 Ibid.

168 South West Africa, Second Phase (1966), Dissenting opinion of Judge Tanaka, 298. Tanaka's dissenting opinion has been considered by Ian Brownlie to be "probably the best exposition of the concept of equality in the existing literature". Brownlie, Basic Documents on Human Rights.

${ }^{169}$ Dugard, '1966 and All That: The South West African Judgment Revisited in the East Timor Case'.

${ }^{170}$ Memorial submitted by the Government of Ethiopia (15 April, 1961), 197.
} 
South Africa admitted that discrimination was against the mandates agreement but claimed that apartheid was differentiation rather than discrimination. ${ }^{171}$ According to South African reasoning, apartheid was a political necessity, and in a way, a continuation of mandatory principles. The "natives" would act as wards to the white population, who would protect them from abuse and exploitation. Thus, the natives would benefit from apartheid and a better quality of life. ${ }^{172}$ The applicants suggested separating the terms by maintaining that "differentiation in the Mandate was protective, whereas apartheid is coercive". ${ }^{173}$ Thus, differentiation according to a membership in a group was allowed in the case that one would be free to leave the group at will. ${ }^{174}$

Many United Nations members would have wanted to see the ICJ give a decision that would have had a real effect on apartheid. ${ }^{175}$ The decision from 1950 was only advisory and there was an urge to find a legally binding way to put pressure on South Africa. Article 7 of the mandate agreement could serve as such. Alexander Pollock claims that by 1966 the majority of the United Nations members saw apartheid as a crime against humanity, suggesting that General Assembly resolution 2145 (XXI) from 1966 was proof of this view. ${ }^{176}$ The United Nations had also been willing to have South West Africa as a trusteeship. Thus, apartheid would have been an inroad through which South Africa could have been legally obliged to change the position of South West Africa. ${ }^{177}$ Also, it was hoped that the judgement would have led those commercially engaged with South Africa, especially Britain and the United States, to put pressure on South Africa to give up apartheid. ${ }^{178}$

The judgement revealed the gap that was now appearing on how the International Court and the rest of the world saw apartheid, human rights and the position of peoples still living in colonies. ${ }^{179}$ The Court's decision on South West Africa was seen as a sign that the Court would set state sovereignty and a strict adherence to the requirements of consent before human rights and the inhabitants of state parties. ${ }^{180}$ This was also the criticism of the dissenting opinions to the

171 D'Amato, 'Legal and Political Strategies of the South West Africa Litigation'.

172 Landis, 'The South West Africa Cases: Remand to the United Nations', 639.

${ }^{173}$ D'Amato, 'Legal and Political Strategies of the South West Africa Litigation', 21.

${ }^{174}$ Ibid.

175 Pollock, 'The South West Africa Cases and the Jurisprudence of International Law', 767.

176 Ibid., 785.

177 D'Amato, 'Legal and Political Strategies of the South West Africa Litigation', 5.

178 Gross, 'The South West Africa Case: What Happened?', 41-42. It is noteworthy that of the commentators, Ernst Gross and Richard Falk had a position as counsels for Ethiopia and Liberia during the proceedings.

179 Victor Kattan argues that there was an internal struggle within the Court mirroring the political struggle outside. Kattan, 'Decolonizing the International Court of Justice'.

180 Dugard, '1966 and All That: The South West African Judgment Revisited in the East Timor Case', 551. 
Court's decision, namely that the Court did not have enough courage to have an impact on the human rights situation in South West Africa. South Africa was still out of reach, but the mandate in South West Africa could have provided the legal means. Rosalyn Higgins, who was herself later to become a judge at the ICJ, wrote immediately after the decision that " $[\mathrm{t}]$ he protection from intervention which the Charter affords states on matters of purely domestic policy (though a limited exception is to be found in the human rights provisions of Articles 55 and 56) has made it extremely difficult to mount effective international opposition to apartheid in South Africa. But specific international obligations attach to the South West Africa Mandate, and it was seen as a possible inroad into the whole question of apartheid." 181

Much of the legal critique on the decision concentrated on the different theories of interpretation applied by the different court members. Alexander Pollock emphasizes the notion of international community, maintaining that this community existed even when the League of Nations ceased to exist. The conservative approach of the formalists would have granted South Africa the permission to act according to how it determined the well-being of the inhabitants of the mandate. However, the language used in relation to the mandates, i.e. as a "sacred trust" of civilization, revealed that the idea had not been to let one party determine the content of this trust, but the task was instead given to the entire community. ${ }^{182}$ Thus, when the League of Nations was dissolved, it was only natural that the United Nations would represent the community, just as the League had done before. ${ }^{183}$ The purpose of the mandate was to promote the wellbeing and social progress of the inhabitants, with the community as an active participant in fulfilling this task. Therefore, according to Pollock, any member of the community, including Liberia and Ethiopia, would have sufficient interests to safeguard the fulfilment of the mandates. ${ }^{184} \mathrm{He}$ also maintained that the concepts of "moral well-being" and "social progress" were such that would necessarily change over time. The standards of the international community were evolving, of which the various UN resolutions condemning South Africa's actions in South West Africa were proof. 185 According to Pollock, by 1966 recognition of human rights as law had evolved to a point where the majority of the members of the United Nations saw apartheid as a human rights violation. ${ }^{186}$

John Dugard criticized the importance given to the travaux préparatoires in the formalistic interpretation of the mandate. According to him, the original intentions

${ }^{181}$ Higgins, 'The International Court and South West Africa: The Implications of the Judgement', 597.

${ }^{182}$ See e.g. Alexandrowicz, 'The Juridical Expression of the Sacred Trust of Civilization'. ${ }^{183}$ Pollock, 'The South West Africa Cases and the Jurisprudence of International Law', 773-774.

184 Ibid., 775 .

185 Ibid., 776.

186 Ibid., 785. 
of the drafters of Article 7(2) of the mandate of South West Africa were not visible in the preparatory works, and thus it was impossible to reach any conclusions based on them. Moreover, as Jessup had reached a completely different outcome reading the same preparatory works, it was clear that an interpretation of the mandate could not be based on them. Had there been a clear intention expressed by the drafters, this could have changed the situation in that the "natural and ordinary" meaning of the text could have been ignored. But as this was not the case, it was to be taken as the starting point of interpretation, in addition to a "rule of effectiveness", which, according to Dugard, had been accepted "as an essential feature in the dynamic development of international law". ${ }^{187}$ The way the Court contrasted law and humanitarianism was, according to Dugard, in contradiction with the Court's own decision in the Corfu Channel Case. ${ }^{188}$ Dugard also believed that the ideas of the international community had evolved to a point where it was entirely feasible to examine the legality of apartheid in the light of the human rights articles of the United Nations Charter, which provided a legal basis, and the relevant General Assembly resolutions, which provided interpretational assistance. ${ }^{189}$

Richard Falk also criticized the decision as the "triumph of judicial conservatism", emphasizing the role of sovereign discretion in the majority's outlook. He contrasted the importance that the 1966 majority gave to the role of sovereign discretion in the formation of legal obligations to the legal relevance that the minority gave to the evolving interpretations of the international community. In his view, if the Court found that there was an international consensus on the interpretation of a legal rule having evolved from the time when they were created, the Court should, by evolving its own legal criteria, give a decision that was acceptable to the international community. ${ }^{190}$ In Falk's view, the true legacy of the decision was to be found in the dissenting opinions of Tanaka and Jessup. ${ }^{191}$ Yet he also pointed out that even when the court made a distinction between law and morality as well as law and politics, it still did not mean that the Court would have sympathized with South African apartheid policies. ${ }^{192}$ Falk believed that for the sake of enforceability, it would have been better if the Court had confirmed South Africa's administrative obligations, rather than the more dramatic humanitarian obligations. ${ }^{193}$

There was a furious reaction to the decision of the Court. Especially many of the new member states of the United Nations saw the decision as proof that the

\footnotetext{
${ }^{187}$ Dugard, 'The South West Africa Cases, Second Phase, 1966', 451.

${ }_{188}$ Corfu Channel case, Judgment of 9 April, 1949: I.C.J. Reports 1949, 4. Ibid., 437.

189 Ibid., 456-457.

${ }^{190}$ Falk, 'The South West Africa Cases: An Appraisal', 14-15.

${ }^{191}$ Ibid., 22; Falk, Reviving the World Court, 117.

${ }^{192}$ Falk, 'The South West Africa Cases: An Appraisal', 7.

193 Ibid., 22.
} 
Court was a "white man's court", not interested in the grievances of the people of the former colonies. ${ }^{194}$ Many saw that the fact that the Court was unable to give a legal decision on the fate of South West Africa meant that the matter had to be resolved by political means. ${ }^{195}$ As the Court had refused to take a stance on the merits of the case, Dugard anticipated that a new advisory opinion on the question of South West Africa was about to follow. ${ }^{196}$ Rosalyn Higgins has pointed out that the parties had invested a considerable amount of time and expense to receive a decision from the Court. As the Court now had declined to give one, there was a true risk concerning the prospects of the use of the Court. ${ }^{197}$ Rather than deciding on the merits, the Court satisfied itself with a very narrow, processual approach. ${ }^{198}$

Higgins mentions that the Court had on a different occasion noted that if the question put in front of the Court was legal, there was no reason for the Court to discuss the possible political motives behind it. Thus, such motives did not turn the issue into a political question which the Court would not have been able to address. ${ }^{199}$

\subsubsection{Conclusions}

The Court's ruling in 1966 was a watershed. In it the Court showed itself to be a white man's court, sticking to the formal interpretation in favour of colonial doctrine. In 1966, at a time when most of the African colonies had gained independence, and the international political focus was on the cultural and political rise of Africa, the decision caused widespread outrage. In its reasoning, the Court, led by Fitzmaurice, had resorted to formalistic originalism deriving obligations from the original intent of the parties in the $1920 \mathrm{~s}$. It thus saw no rights for the applicants and completely avoided the issue of apartheid. The Court was, however, split and the more modern view was expressed in dissent. Judges Jessup and Tanaka presented a teleological interpretation of the obligations

${ }^{194}$ McWhinney, 'The Changing United Nations Constitutionalism: New Arenas and New Techniques for International Law-Making', 77; Falk, 'The South West Africa Cases: An Appraisal', 1,4; Higgins, 'The International Court and South West Africa: The Implications of the Judgement', 593; Friedmann, 'The Jurisprudential Implications of the South West Africa Case', 10; Stone, 'Reflections on Apartheid after the South West Africa Cases', 1069-1070.

${ }^{195}$ Highet, 'The South West Africa Cases', 161; Dugard, 'The Revocation of the Mandate for South West Africa', 82.

${ }^{196}$ Dugard, 'The South West Africa Cases, Second Phase, 1966', 457, 460; Higgins, 'The International Court and South West Africa: The Implications of the Judgement', 595.

${ }^{197}$ Higgins, 'The International Court and South West Africa: The Implications of the Judgement', 593; Falk, 'The South West Africa Cases: An Appraisal', 19.

${ }^{198}$ McWhinney, 'The Changing United Nations Constitutionalism: New Arenas and New Techniques for International Law-Making', 76; Falk, 'The South West Africa Cases: An Appraisal', 7.

${ }^{199}$ Higgins, 'The International Court and South West Africa. The Implications of the Judgement', 589. See also Friedmann, 'The Jurisprudential Implications of the South West Africa Case', 10. 
stressing the primacy of human rights in the United Nations framework. Thus, in Tanaka's thinking, the universal nature of human rights meant that there could not be persistent objectors to them or the obligations that they presented. In comparison, the defence of South Africa to the claims that apartheid was a violation of its obligations, was the resort to the language of colonial paternalism, where the natives were seen as wards to the white man. In the context of 1966, this formulation was breathtakingly out of touch with political realities of the decolonization movement.

\subsection{The Court Redeems Itself: 1971 Advisory Opinion on the Legal Consequences for States concerning the Continued Presence of South Africa in Namibia}

The initial outrage grew into sustained criticism that led to questions being raised about the legitimacy of the Court itself. The issue of Namibia had begun to threaten the legitimacy of the UN. Numerous resolutions by the General Assembly and the Security Council had called for South Africa to withdraw and had sought to terminate the mandate. The aim of this section is to discuss the 1971 advisory opinion on the Legal Consequences for States of the Continued Presence of South Africa in Namibia (South West Africa) notwithstanding Security Council Resolution 276 (1970), in which the issue was brought once more to the ICJ, whose composition had once again changed. In it, the Court reversed its previous ruling and rejected the formalistic and static interpretation and instead argued that even the Covenant of the League of Nations should be subject to an evolutionary interpretation which took into consideration legal and social changes. Accordingly, the Court would reaffirm the right of self-determination and find South Africa to be in breach of its obligations. The UN had, of course, already terminated the mandate in 1966 with the General Assembly Resolution 2145 (XXI).

The issue was brought to the Court not by individual member states, but by the Security Council itself, which had in its resolution declared South Africa's continued presence in South West Africa, which was increasingly called by the name Namibia, illegal. The request for an advisory opinion was presented by Finland, which was considered to be a neutral country and not part of the Cold War alliances. The question that was posed to the Court was completely different than had been discussed before. The task given to the ICJ was to answer, "what are the legal consequences for States of the continued presence of South Africa in Namibia, notwithstanding Security Council resolution 276 (1970)?". This resolution declared the presence of South Africa in Namibia to be illegal. ${ }^{200}$

${ }^{200}$ As the Court was asked to give an advisory opinion, it could not approach the matter similarly to what it had done in the contentious cases brought by Ethiopia and Liberia. Advisory opinions cannot be used to circumvent the consent that is required of all parties. Yet it is not always easy to define whether the Court is asked to give an abstract legal 
According to the Court (repeating its old decisions), the nature of the mandate was a trust that was intended for the benefit of the peoples concerned. These peoples, the Court now emphasized, had interests of their own and a potentiality for independent existence. ${ }^{201}$ Thus, the object and purpose of the mandate was the same as in the A and B mandates (contrary to what South Africa had claimed), namely the eventual independence of all mandates. ${ }^{202}$ One of the greatest differences in the Court's reasoning as compared to 1966 was that the Court now declared that its interpretation was to take into account subsequent changes in international law (in the United Nations and various declarations), including also customary law, as well as the shift from a colonial era to a post colonial one. ${ }^{203}$ The Court noted that the concepts of Article 22 of the Covenant of the League of Nations were not static, but were by definition evolutionary. Therefore, the Court could not interpret Article 22 according to the law and ideals of the 1920s, but had to take the subsequent legal and societal changes into consideration. According to the Court, "[The Government of South Africa] puts too much emphasis on the intentions of some of the parties and too little on the instrument which emerged from those negotiations." ${ }^{204}$ The Court declared that the ultimate objective of "sacred trust" was self-determination, and thus accordingly, independence should be possible in Namibia as well. ${ }^{205}$ The idea forwarded by South Africa that Namibia would be annexed to its territory was declared unacceptable. It was unthinkable that after World War II, in an era of post-colonialism, a mandate would revert to a colony, when this had been ruled out already in the 1920 s. 206

opininion, or whether there is a legal dispute between two or more states. See e.g. Legal Consequences of the Construction of a Wall in the Occupied Palestinian Territory, Advisory Opinion (2004), 159, para. 50, where the Court maintained that "The opinion is requested on a question which is of particularly acute concern to the United Nations and one which is located in a much broader frame of reference than a bilateral dispute. In the circumstances, the Court does not consider that to give an opinion would have the effect of circumventing the principle of consent to judicial settlement, and the Court accordingly cannot, in the exercise of its discretion, decline to give an opinion on that ground". Zimmermann et al., The Statute of the International Court of Justice, 211, 217, 1618.

${ }^{201}$ Legal Consequences for States of the Continued Presence of South Africa in Namibia (South West Africa) notwithstanding Security Council Resolution 276 (1970), Advisory Opinion, I.C.J. Reports 1971, para. 46.

${ }^{202}$ Legal Consequences for States of the Continued Presence of South Africa in Namibia (1971), para. 54.

${ }^{203}$ Legal Consequences for States of the Continued Presence of South Africa in Namibia (1971), para. 53.

${ }^{204}$ Legal Consequences for States of the Continued Presence of South Africa in Namibia (1971), para. 45. See also para. 50.

${ }^{205}$ Legal Consequences for States of the Continued Presence of South Africa in Namibia (1971), para. 52 and 53. On the nature of the right to self-determination in the Namibia decision, see Klabbers, 'The Right to Be Taken Seriously', 191-192.

${ }^{206}$ Legal Consequences for States of the Continued Presence of South Africa in Namibia (1971), para. 57. 
The Court based its legal reasoning mainly on South Africa's breach of obligations as a mandatory. As a starting point, the Court used the extensive number of General Assembly and Security Council resolutions concerning South Africa's presence in Namibia. The first General Assembly resolutions date from the 1940s, including a General Assembly resolution from April 18, 1946 on the continuation the mandates and General Assembly resolution from December 14, 1946, where the General Assembly did not accept the incorporation of South West Africa into South Africa and recommended that South West Africa be turned into a trusteeship. Between 1946 and 1956 trusteeship was recommended in several other General Assembly resolutions as well. From the point of view of this case, the most relevant General Assembly resolution was GA Res 2145 (XXI) from 1966, where the General Assembly declared the mandate of South West Africa to be terminated.207 The cause of termination was South Africa's failure to fulfil its obligations to ensure the moral and material well-being of the indigenous inhabitants. ${ }^{208}$ The Court referred to its 1962 decision, where it had noted that the mandate had been a special type of instrument and an entirely novel regime. As the legal ground, according to which the instrument could now be terminated, the Court used the breach of obligations clause in the Vienna Convention on the Law of Treaties ${ }^{209}$ and customary international law. The Court noted that there was a right to terminate a relationship in the case of a deliberate and persistent violation of obligations which destroys the very object and purpose of that relationship. ${ }^{210}$ In this case, the obligation was to ensure the moral and material well-being of the indigenous inhabitants that South Africa through the use of apartheid had violated, and therefore, the General Assembly had the right to terminate the mandate. South Africa, for its part, had stated that as the mandate was silent on the questions of termination, there were no legal grounds to terminate the mandate. This the Court however denied. ${ }^{211}$ South Africa had also complained that the General Assembly was not competent to act as a non-juridical organ. The Court pointed out that in 1966 it had declared that the matter belonged to political

207 "The General Assembly [...] [d] ecides that the Mandate conferred upon His Britannic Majesty to be exercised on his behalf by the government of the Union of South Africa is therefore terminated, that South Africa has no other right to administer the territory and that henceforth South West Africa comes under the direct responsibility of the United Nations." General Assembly Resolution 2145 (XXI) of 27 October, 1966, para. 4.

${ }^{208}$ Legal Consequences for States of the Continued Presence of South Africa in Namibia (1971), para. 93. In the 1971 opinion the Court for the first time used the term "indigenous" to refer to the inhabitants of the mandate. In the 1960s the Court referred to "inhabitants". In the 1950 opinion there is one reference to "native populations", but the Court is here referring to a speech given by the representative of South Africa in the UN General Assembly (p. 142).

${ }^{209}$ Vienna Convention on the Law of Treaties (1969), Article 60.

${ }^{210}$ Legal Consequences for States of the Continued Presence of South Africa in Namibia (1971), para. 95.

${ }^{211}$ Legal Consequences for States of the Continued Presence of South Africa in Namibia (1971), para. 96. 
organs, that is, to non-juridical organs. This was still valid, as someone must have competence to terminate the mandate. ${ }^{212}$ In addition to the General Assembly, the Security Council had given several resolutions to implement the General Assembly resolutions. Security Council resolutions 245 (1968), 246 (1968) and 269 (1969) called South Africa to withdraw from Namibia. The most important one, the interpretation of which was now under the Court's consideration, was Security Council Resolution 276 (1970). In this resolution the Security Council declared South Africa's presence and actions illegal and called upon the states to refrain from any dealings with South Africa. ${ }^{213}$ The Security Council's authority for its decision was based on the maintenance of peace and security, ${ }^{214}$ and thus, according to Articles 24 and 25 of the Charter of United Nations, were binding on all member states. As a conclusion, the Court declared that South Africa had an obligation to put an end to the illegal situation and that all member states were under an obligation to recognize this illegality and to refrain from rendering any support to South Africa. ${ }^{215}$

Even though the Court based its decision mainly on South Africa's treatybased obligations and the violations thereof, for the first time the human rights of the inhabitants and human rights language were used in the ICJ as a legal basis for its decision on South West Africa. General Assembly Resolution 2145 (XXI)

${ }^{212}$ Legal Consequences for States of the Continued Presence of South Africa in Namibia (1971), para. 103.

213 "The Security Council, Reaffirming the inalienable right of the people of Namibia to freedom and independence recognized in General Assembly resolution 1514 (XV) of 14 December 1960,

Reaffirming General Assembly resolution 2145 (XXI) of 27 October, 1966, by which the United Nations decided that the Mandate for South West Africa was terminated and assumed direct responsibility for the Territory until its independence,

Reaffirming Security Council resolution 264 (1969) of 20 March, 1969 in which the Council recognized the termination of the Mandate and called upon the Government of South Africa to withdraw immediately its administration from the Territory,

Reaffirming that the extension and enforcement of South African laws in the Territory together with the continued detentions, trials and subsequent sentencing of Namibians by the Government of South Africa constitute illegal acts and flagrant violations of the rights of the Namibians concerned, the Universal Declaration of Human Rights and the International status of the Territory, now under direct United Nations responsibility,

Recalling Security Council resolution 269 (1969) of 12 August 1969,

1. Strongly condemns the refusal of the Government of South Africa to comply with the resolutions of the General Assembly and Security Council pertaining to Namibia;

2. Declares that the continued presence of the South African authorities in Namibia is illegal and that consequently all acts taken by the Government of South Africa on behalf of or concerning Namibia after the termination of the Mandate are illegal and invalid; [...]."

${ }^{214}$ Legal Consequences for States of the Continued Presence of South Africa in Namibia (1971), para. 109.

${ }^{215}$ Legal Consequences for States of the Continued Presence of South Africa in Namibia (1971), para. 118-119. 
1966 declared that "the Mandated Territory by South Africa has been conducted in a manner contrary to the Mandate, the Charter of the United Nations and the Universal Declaration of Human Rights". South Africa denied this, claiming that the continuation of the sacred trust and the benefit and desire of the inhabitants (as well as its original conquest and long occupation) were the very reasons for its right to annex the mandated territory. ${ }^{216}$ The Court strongly disagreed and noted that "no factual evidence is needed to determine whether apartheid is in violation of South Africa's international obligations".217 "Under the Charter of the United Nations, the former Mandatory had pledged itself to observe and respect, in a territory having an international status, human rights and fundamental freedoms for all without distinction as to race. To establish instead, and to enforce, distinctions, exclusions, restrictions and limitations exclusively based on grounds of race, colour, descent or national or ethnic origin which constitute a denial of fundamental human rights is a flagrant violation of the purposes and principles of the Charter." ${ }^{18}$ Thus, human rights now appeared to give a content and meaning to the "moral and material well-being" of the inhabitants of Namibia. In its 1971 decision the Court finally entered the world of decolonization. The instruments that the Court claimed South Africa to have violated, the mandate, the Charter of the United Nations and the Universal Declaration of Human Rights, were not new. All of these sources would have been available when the Court gave its decisions in 1963 and 1967.219 This time the Court gave an explicitly legal meaning to the mandate.

Judge Fitzmaurice, however, brushed away the questions of "humanitarianism" at the beginning of his dissenting opinion. He positioned himself as a "jurist", placing himself in opposition to the rest of the Court. Once again he maintained that the fact that South Africa's conduct, i.e. apartheid, was detrimental to "the material and moral well-being and the social progress" of the inhabitants of South West Africa, had not been determined legally. He was not ready to accept that it could be merely deduced from South African laws that apartheid was harmful to the inhabitants. ${ }^{220}$ Rather, the Court should have

${ }^{216}$ Legal Consequences for States of the Continued Presence of South Africa in Namibia (1971), para. 128.

217 Legal Consequences for States of the Continued Presence of South Africa in Namibia (1971), para. 129.

218 Legal Consequences for States of the Continued Presence of South Africa in Namibia (1971), para. 131.

219 The Vienna Convention of the Law of Treaties was signed in 1969. However, it had been in preparation for several years and is widely believed to codify customary international law. Article 60 had been suggested in a more limited form in 1957 by Fitzmaurice and was generally accepted by the International Law Commission in 1963. Villiger, Commentary on the 1969 Vienna Convention on the Law of Treaties, 736-737 on the history of the article and 749-750 on the customary basis of the article.

${ }^{220}$ Legal Consequences for States of the Continued Presence of South Africa in Namibia (1971), Dissenting opinion of Judge Sir Gerald Fitzmaurice, para. 4. 
investigated the claims in order to be legally able to make this point. In essence, Fitzmaurice criticized the Court for intellectual laziness, and failing to delve deeply into the matter as a proper jurist should.

However, according to Fitzmaurice, this was all beside the point and secondary to the fact that the mandate was interpreted incorrectly. Calling his own method of interpretation "orthodox", he wished to emphasize the "intentions of those concerned at the time". According to him, the Court had an "alien philosophy", as it used the intentions and aims of institutions of a different era, 50 years after the establishment of such institutions. "This," he said, "is not a legally valid criterion... ."221 If the resolution drafted by Fitzmaurice and Spender had in 1966 appeared as conservative and old fashioned, now the formalism of Fitzmaurice showed him as a man of the past, unable to accept the obvious.

With its ruling, the ICJ cautiously accepted international human rights as a guiding principle in its interpretation. Such teleological argumentation extended the validity of these principles even to the interpretation of much earlier obligations and treaties, such as the mandates. The Czech human rights lawyer, Egon Schwelb, maintained in a commentary of the case that in its decision the Court showed that the United Nations Charter included binding human rights obligations. According to him, the Court had terminated the mandate because of human rights violations, i.e. violations of the Charter's human rights provisions. ${ }^{222}$ Schwelb's comment relates to a broader discussion that was going on about whether the UN Charter's human rights provisions provided for binding obligations on all UN members. While it is true that the Court refers to the human rights articles of the Charter and the Universal Declaration of Human Rights, it is noteworthy that the Court declared the actual violation by South Africa to be a violation of its duties as a mandatory, i.e. a violation of the mandates agreements. When the Court referred to the source of South Africa's obligations, it referred to Article 22 of the League Covenant and the South West Africa mandate agreement. The Court terminated South Africa's tasks based on the League Covenant and the mandate, using the Vienna Convention on the Law of Treaties as an interpretational tool, since the first mentioned agreements were silent on termination. The Court referred to South Africa's Charter-based human rights duties only as a response to South Africa's claim that its policy of apartheid was "directed in good faith towards the purpose of promoting to the utmost the wellbeing and progress of the inhabitants".223 The Court was not willing to delve deeply into the matter of apartheid, but concluded that South Africa's policies of apartheid were a violation of the purposes and principles of the Charter.

221 Ibid., para. 7.

222 Schwelb, 'The International Court of Justice and the Human Rights Clauses of the Charter', 349;. See also Rodley, 'Human Rights and Humanitarian Intervention', 324.

${ }^{223}$ Legal Consequences for States of the Continued Presence of South Africa in Namibia (1971), para. 128-131. 
Natalie Hevener has described the advisory opinion through its liberal interpretation of customary law. She notes that the Court referred to both the United Nations Charter and also actual events (namely de-colonization) as relevant in the emergence of new law, and also that the period during which this law evolved was rather brief. ${ }^{224}$ She also refers to the discussions on whether the human rights norms of the United Nations Charter could be seen as binding law, noting that the Court's approach "expands the limits of the law in a juridically legitimate fashion, but in opposition to those who propound a narrower definition of these obligations". 225 Thus, the division within the Court between the more formalistic approach to the legal relevance of human rights norms and the teleological approach was still visible in the decision and the dissenting opinion, as can be seen in Fitzmaurice's opinion. She concludes that while the teleological approach is only implicit in the judgment, it seems that the Court wished to confirm human rights issues as being part of international law: "it must have seemed wise to explicate its reasoning with the firmest traditional bases possible". 226

Dugard also approaches the case as a victory for the progressive interpretation of international law, seeing it particularly fitting for treaties of a humanitarian nature.227 In his view, the Court, by accepting teleological interpretation as "recognized and accepted for legal reasoning", acknowledged that there are uncertainties and controversies relating to humanitarian matters that nevertheless do not change their position as valid law. 228

\subsection{Conclusions on the South West Africa cases}

Read one after the other, the cases of the International Court of Justice on South Africa's governance in South West Africa, form an incoherent picture on what the Court saw as its role in safeguarding human rights. Yet, the South West Africa cases are often grouped as one single case when given as an example of the ICJ's development of self-determination and human rights law. Rosalyn Higgins has described the Court as a "forerunner in recognizing self-determination as a legal right". ${ }^{229}$ Bruno Simma refers to both the negative (the South West Africa decision of 1966) and the positive (the Namibia advisory opinion) outcomes in terms of self-determination and human rights. ${ }^{230}$ Gentian Zyberi notes the Court's

\footnotetext{
${ }^{224}$ Hevener, 'The 1971 South-West African Opinion', 797.

225 Ibid., 801.

226 Ibid., 808.

227 Dugard, 'Namibia (South West Africa): The Court's Opinion, South Africa's Response, and Prospects for the Future', 37.

${ }^{228}$ Ibid., 38.

${ }^{229}$ Higgins, 'Human Rights in the International Court of Justice', 747.

${ }^{230}$ Simma, 'Mainstreaming Human Rights: The Contribution of the International Court of Justice', 12.
} 
contribution in both defining the aim and scope of the right to self-determination and linking it to fundamental human rights. ${ }^{231}$ However, the language of all the cases is different and they span over a period of more than two decades, highlighting how human rights were mainstreamed by the Court only in the 1970s.

${ }^{231}$ Zyberi, 'Self-Determination through the Lens of the International Court of Justice', 436. 


\section{Conclusions}

The stated purpose of this research has been to trace the emergence of rights language in the League of Nations mandates system. I have followed the debates regarding the mandates system from its inception in the aftermath of the First World War up to the 1971 decision of the ICJ regarding the application of a cautious human rights standard in Namibia. Through the discussions among international lawyers and the proceedings of the Permanent Mandates Commission, I have followed not only how the mandates were conceived, conceptualized, and administered but also how they have been interpreted after the League itself ceased to exist.

Philip Alston has asked whether it matters if rights have a genealogy. Is it necessary to trace human rights centuries back? Alston himself has answered the question by not having interest in pinpointing the emergence of a phenomenon to a certain exact moment. However, he has maintained that ideas and phenomena are not born in a vacuum. Human rights are a complex phenomenon and the discussion of their history have been partly limited because of debates on how to define them. One cannot look at them from just one point of view without getting a distorted picture.

I have not been looking for precedents or antecedents of human rights, but rather for reasons and developments, using the discussions of the Permanent Mandates Commission as my case study. As many have noted, the language and terms one uses affect the results of a study. I have used terminology in an openended way, tracing those discussions in the Permanent Mandates Commission that have later had a meaning within the human rights phenomenon. The open endedness naturally leads to the danger that anything can be seen as a precursor of human rights. To counter this, I have aimed to find concrete issues that have been later deliberated within the context of human rights and studied the ways they have been discussed during the interwar period. The discussions have shown that there exists no tidy lineage of rights talk or that rights would have gradually developed in a predictable fashion in order to culminate in a human rights revolution after the Second World War.

In this study I have described broadly the language and deliberations of the Permanent Mandates Commission. I have been able to find continuities in language and notions from earlier decades predating the mandates system, but I have also found discontinuities. On the other hand, the discussions have shown that changes in the language of rights as compared to those that have taken place after the Second World War have been rather small. In questions relating to mandates and colonies in general, there is no such change in language that would justify talking about a human rights revolution immediately after the war. The change took place more than two decades later, when the postcolonial era had already begun.

Certain principles relating to the mandates, such as self-determination and non-annexation, emerged already in the establishing phases of the system. The 
interpretation of self-determination in particular had an important role throughout the history of the mandates system, even if it had only very little practical meaning in the interwar period. Principles such as "material and moral well-being", "development", "tutelage" as a means to achieve these principles, and "sacred trust" were written into Article 22 of the League Covenant and were central to the decisions concerning the mandate of South West Africa in the International Court of Justice in the 1960s and in 1971.

The interpretation of the concepts of trust and tutelage are closely linked to the possible rights-based interpretation of the mandates. The concept of "sacred trust" was not established, but was affected by the period of interpretation and the ideologies of the interpreter. In the early years of the mandates, Lord Lugard saw these concepts in the light of the colonial period: they were the "latest expression of the conscience of Europe". ${ }^{1}$ Thus, they were an improved version of traditional colonialism. The mandates were to serve as a model for colonial administration and as such the responsibility of superior civilizations towards inferior ones should be apparent in their execution. This responsibility was conceived to be both material and moral. "Sacred trust" was widely seen as a moral and ethical concept, a humanitarian obligation without a legal meaning. ${ }^{2}$ A similar approach was maintained by the ICJ. In its advisory opinion of 1950, the ICJ described the "sacred trust" through the wording of the League of Nations as an international institution in the interest of the inhabitants of the territory and humanity in general, giving certain obligations to the mandatory. In its 1966 decision on South West Africa, the Court clearly pointed out that it believed the "sacred trust" to be a moral ideal, unsuited for legal interpretation. Such "humanitarian considerations" could be used as an "inspirational basis" for drafting legal rules, but did not have a legal content as such. In the 1971 Advisory Opinion on the Legal Consequences for States concerning the Continued Presence of South Africa in Namibia, the Court would finally give a legal meaning to the "sacred trust". First of all, the Court confirmed both the continuing existence of the "sacred trust", now including all territories under a colonial regime, and the evolutionary nature of it. According to the Court, the ultimate object of the "sacred trust" was self-determination and independence of the peoples of non-self-governing territories. Thus, the meaning the Court gave to the concept of "sacred trust" was not one of human rights as such, but rather related to the duty to grant the peoples of Namibia the right to independently decide of their own future.

The mandates system had many features that were common to contemporary colonial policies. It was based on old ideas of the superiority of European culture and the "white man's burden", and the responsibility to raise inferior cultures to a higher level of civilization. The mandatories mainly treated the mandates as if they were their colonies. There were differences, but these related to differences in their

\footnotetext{
${ }^{1}$ Lugard, The Dual Mandate in British Tropical Africa, 50.

${ }^{2}$ Wortley, 'Idealism in International Law: A Spanish View of the Colonial Problem', 156; Chowdhuri, International Mandates and Trusteeship Systems, 10; Hall, Mandates, Dependencied and Trusteeship, 46-47.
} 
other colonial policies as well. Similarly, the discussion of the PMC show that they saw their role towards the natives as civilizers, and themselves as culturally superior. It was rather clear that they would not encourage the mandates to become independent and they lacked the belief that the mandated territories could actually act as independent nations. Even if the independence of the A mandates had already been conditionally accepted, the independence process of Iraq showed that the PMC did not genuinely believe that the inhabitants of Iraq had achieved a sufficient level of civilization to justify independence. As with contemporary scholarship on international law, Europe was the measuring stick for civilization and from the point of view of the PMC, the mandates were considered to be too far behind to even be given independence some day. Lord Lugard's thinking, for instance, showed his old colonial ideals. On the other hand, of the PMC members William Rappard believed that colonial administration could be transferred to international control through the mandates system and that the League of Nations brought order to international relations. One could, in fact, expect something novel and better of the mandates system.

The practicalities of the mandates system, the discussion, reports, petitions, and so on, gradually started to have a life of their own. Through petitions, the inhabitants were able to express their grievances. The petitions did not come evenly from all territories, but their number was vast and through them the PMC had access to such information that had never been discussed in old colonial administrations. Most petitions would not lead to concrete actions, but they were discussed and they gained publicity, and thus entered into a broader awareness. Moreover, while it would be an exaggeration to say that the petitions dealt with individual rights, through them the concerns and grievances of individual inhabitants came to the knowledge of the PMC and were discussed before it.

In this study I have examined several of the "safeguards" granted by Article 22 of the League Covenant and the individual mandates agreements, all of which reveal something about the relationship between the administration and the inhabitants, the PMC being included in this relationship. By drafting a questionnaire, the PMC developed a standardized format with which it could require information from the mandatories. It also specified the questionnaire a few years later after it noticed that the information it received from the mandatories was not specific enough.

It was common to all "safeguards" that the PMC considered its own role and the role of the administration to be that of a protector. In contrast to modern human rights thought, the threat to the "rights", or rather to the welfare of the inhabitants, were the inhabitants themselves or other local groups. The task of the administration was to ensure that the inhabitants would not harm themselves or others with their primitive ways. This was especially apparent in questions relating to slavery and the position of women. The PMC repeatedly observed that the situation would improve by itself, as the level of civilization would rise. The advance of civilization would teach the natives to take better care of themselves. They would also develop more modern concepts of labour, ownership and the 
positions of women. Also in matters relating to land usage, it was the task of the administration to determine both what the "rights" and interests of the inhabitants were and to guarantee the realization of these rights.

A contradiction between protection, preservation of cultural values and modernization was apparent in the discussions on the "safeguards". Material development and new infrastructure required labour, but at the same time the inhabitants needed protection from exploitation. Yet, there were members in the PMC who believed that labour was the ultimate means for civilization and education and the civilizational task was more important than the protection of the inhabitants. There were also traditions concerning land usage, but, on the other hand, modernization required that the inhabitants understood the concept of ownership. Local religions were to be protected in the name of religious freedom, and yet, they included practices that the PMC found appalling. The same applied to the position of women.

The "safeguards" were closely related to the standard of civilization. The idea of a superior European civilization meant that Europeans had a duty to guarantee certain "rights", such as freedom of religion. Similarly, the prohibition of slavery had already in the $19^{\text {th }}$ century been a means for Europeans (and especially the British) to show their moral superiority. Fighting slavery would justify colonial administration. In the mandates system the idea of a standard of civilization was highly visible in the PMC distrust of Iraq's ability to take care of its minorities. The PMC feared that once European supervision would end, the minorities in Iraq would be under immediate threat.

Of the different "safeguards", the abolition of the slave trade has most often been linked to human rights and their development. However, freedom of religion, labour laws and the various conventions regarding the position of women have found a place in histories of human rights. Yet, as is quite apparent from the manner in which these issues were treated by the PMC, during the mandates period they were not seen as individual rights, not to mention human rights, and they had very little resemblance to the human rights thought of today. The PMC was more concerned with the development of the society at large, expecting that changes in the position of individuals would not interfere with this development. Yet, many members of the PMC did show a genuine benevolent attitude towards the native inhabitants and a sense of morality in their discussions. Of course, this did not mean that they could be considered to have a human rights sensibility, but rather a paternalistic attitude towards the inhabitants.

Anne Orford has written that a lawyer has a different outlook on the origins of legal phenomena than a historian. In her view, a lawyer does not necessarily get acquainted with the origins of a concept or a norm only to explain the past, but also to find support for interpretation and application of the concepts. Lawyers should at least be self-conscious about the method of interpretation they aim to use. In the cases in the International Court of Justice on the position of South West Africa this has been visible in the discussion on the nature of the mandates and the different methods of interpretation. For reasons mentioned by Orford, a lawyer does not 
always need to be afraid of anachronism, as a certain degree of anachronism is inherent in the application of law.

The formalistic interpretation of Article 22 of the Covenant of the League of Nations and the entire mandates system in the decision of the ICJ in 1966 would leave no room for human rights to enter the mandates system even in hindsight. As the interpretation of the Court was based on the original idea of the League of Nations of the nature of mandates, it was quite natural that any references to human rights would have been anachronistic. Finding support for interpretation from the travaux préparatoires gave little support to the right to self-determination and no support for including a broader interpretation based on human rights in the mandates system. However, the dissenting opinions showed that there were other possible ways to interpret the relationship between mandates and human rights. As Orford notes, lawyers can throw aside their fear of anachronism and search for assistance in interpreting the object and purpose of a treaty. They can consider that their duty is to interpret the material from the perspective of present-day values and norms. In 1971, the ICJ determined that the ultimate objective of the "sacred trust" was self-determination. Similarly, the Court maintained that Article 22 of the League Covenant obliged South Africa to take care of the moral and material wellbeing of the indigenous inhabitants of South West Africa. Even here the Court was cautious in making an interpretation based on human rights. It maintained that due to a treaty violation, that is, a violation of the duty to ensure the moral and material well-being of the native inhabitants by its policy of apartheid, the mandate could be terminated. In the Court's reasoning, the human rights clauses of the United Nations Charter gave content to the notion of "moral and material well-being". Apartheid was a violation thereof. With this decision, the ICJ, albeit still very cautiously, gave the mandates system a meaning within the human rights phenomenon. 


\section{Bibliography}

Afshari, Reza. 'On Historiography of Human Rights. Reflections on Paul Gordon Lauren's The Evolution of International Human Rights: Visions Seen'. Human Righto Quarterly 29 (2007): 1.

Alexandrowicz, C. H. 'The Juridical Expression of the Sacred Trust of Civilization'. American Journal of International Law 65 (1971): 149.

Allain, Jean. 'Slavery and the League of Nations: Ethiopia as a Civilised Nation'. Journal of the History of International Law 8 (2006): 213.

- - - . 'The Legal Definition of Slavery into the Twenty-First Century'. In The Legal Understanding of Slavery. From the Historical to the Contemporary, edited by Jean Allain, 199. Oxford: Oxford University Press, 2012.

Alston, Philip. 'Does the Past Matter? On the Origins of Human Rights. Book Review. Jenny Martinez, The Slave Trade and the Origins of International Human Rights Law.' Harvard Law Review 126 (2013): 2043.

Ampiah, University of Leeds Kweku. The Political and Moral Imperatives of the Bandung Conference of 1955. Folkestone, UK: Brill/Global Oriental, 2007.

Anghie, Antony. 'Colonialism and the Birth of International Institutions: Sovereignty, Economy, and the Mandate System of the League of Nations'. New York University Journal of International Law and Human Rights 34 (2001-2002): 513.

- - - Imperialism, Sovereignty, and the Making of International Law. Cambridge: Cambridge University Press, 2005.

- - - . 'Nationalism, Development and the Postcolonial State: The Legacies of the League of Nations'. Texas International Law Review 41 (2006): 447.

- - - . 'The Heart of My Home, Colonialism, Environmental Damage and the Nauru Case'. Harvard International Law Journal 34 (1993): 445.

Banner, Stuart. How the Indians Lost Their Land: Law and Power on the Frontier. Cambridge, Mass.: Belknap Press, 2007.

Bass, Gary J. Freedom's Battle: The Origins of Humanitarian Intervention. New York: Vintage, 2009.

Benton, Lauren, and Aaron Slater. 'Constituting the Imperial Community: Rights, Common Good, and Authority in Britain's Atlantic Empire, 1607-1815.' In Revisiting the Origins of Human Rights, edited by Miia Halme-Tuomisaari and Pamela Slotte. Cambridge: Cambridge University Press, 2015.

Bentwich, Norman. The Mandates System. London: Longmans, Green and Co., 1930.

Bernhardt, Rudolf. 'Homogenität, Kontinuität und Dissonanzen in der Rechtsprechung des Internationalen Gerichtshofs. Eine Fall-Studie zum Südwestafrika/NamibiaKomplex'. Zeitschrift für ausländisches öffentliches Recht und Völkerrecht 33 (1973): 1.

Bernstorff, Jochen von. 'The Changing Fortunes of the Universal Declaration of Human Rights: Genesis and Symbolic Dimensions of the Turn to Rights in International Law'. European Journal of International Law 19 (2008): 903.

Blackburn, Robin. The American Crucible. Slavery, Emancipation and Human Rights. London, New York: Verso, 2011.

Blondel, André. 'Le Cessation Des Mandats et Le Cas de l'Iraq'. Revue Générale de Droit International Public 39 (1932): 614.

Blumenthal, Henry. 'Woodrow Wilson and the Race Question'. The Journal of Negro History 48 (1963): 1.

Bluntschli, Johann Caspar. Das Moderne Völkerrecht Der Civilisierten Staaten Als Rechtsbuch Dargestellt. Nördlingen: Beck, 1868.

Bonfils, Henry. Manuel de Droit International Public. Paris: Arthur Rousseau, 1894.

Bring, Ove. De Mänskliga Rättigheternas Väg. Stockholm: Atlantis, 2011.

Brownlie, Ian. Basic Documents on Human Rights. Oxford: Clarendon Press, 1971. 
- - - . Principles of Public International Law. 5th edition. Oxford: Oxford University Press, 1998.

- - - Principles of Public International Law. 6th edition. Oxford: Oxford University Press, 2003.

Buergenthal, Thomas. 'The Evolving International Human Rights System'. The American Journal of International Law 100 (2006): 783.

Buergenthal, Thomas, Dinah Shelton, and David Stewart. International Human Rights in a Nutshell. 4th edition. St. Paul, MN: West Academic Publishing, 2009.

Burgers, Jan Herman. 'The Road to San Francisco: The Revival of the Human Rights Idea in the Twentieth Century'. Human Rights Quarterly 14 (1992): 447.

Burke, Roland. Decolonization and the Evolution of International Human Rights. Philadelphia: University of Pennsylvania Press, 2010.

Callahan, Michael D. A Sacred Trust: The League of Nations and Africa, 1929-1946. Brighton: Sussex Academic Press, 2004.

- - _. Mandates and Empire: The League of Nations and Africa, 1914-1931. Brighton: Sussex Academic Press, 1999.

Campbell Lee, D. 'Mandates: How They Are Working'. Transactions of the Grotius Society 12 (1926): 31.

Carter Mills, Mark. 'The Mandatory System'. The American Journal of International Law 17 (1923): 50.

Cecil, Lord Robert. The New Outlook. London: George Allen \& Unwin Ltd., 1919.

Chowdhuri, Ramendra Nath. International Mandates and Trusteeship Systems, a Comparative Study. The Hague: M. Nijhoff, 1955.

Cmiel, Kenneth. 'The Recent History of Human Rights'. The American Historical Review 109 (2004): 117.

Cooper, Frederick. Decolonization and African Society: The Labor Question in French and British Africa. Cambridge: Cambridge University Press, 1996.

Cooper, John Milton. Breaking the Heart of the World: Woodrow Wilson and the Fight for the League of Nations. Cambridge: Cambridge University Press, 2001.

- - - . Woodrow Wilson: A Biography. New York: Knopf, 2009.

Cowan, Jane. 'Who's Afraid of Violent Language? Honour, Sovereignty and ClaimsMaking in the League of Nations'. Anthropological Theory 33 (2003): 271.

Crafford, F. S. Jan Smuts: A Biography. Garden City, New York: Doubleday, Doran \& co., inc., 1943.

Craven, Matthew. The Decolonization of International Law. State Succession and the Law of Treaties. Oxford: Oxford University Press, 2007.

Crawford, James. Brownlie's Principles of Public International Law. 8th edition. Oxford: Oxford University Press, 2012.

Crozier, Andrew J. 'The Establishment of the Mandates System, 1919/1925: Some Problems Created by the Paris Peace Conference'. Journal of Contemporary History 14 (1979): 483.

Curry, George. 'Woodrow Wilson, Jan Smuts, and the Versailles Settlement'. American Historical Review 66 (1961): 968.

D’Amato, Anthony A. 'Legal and Political Strategies of the South West Africa Litigation'. Law in Transition Quarterly 4 (1967): 8.

Daughton, J. P. 'ILO Expertise and Colonial Violence in the Interwar Years'. In Globalizing Social Rights. The International Labour Organization and Beyond, edited by Sandrine Kott and Joëlle Droux, 85. Houndmills, Basingstoke and Geneva: Palgrave Macmillan and International Labour Office, 2013.

Dedering, Tilman. 'Petitioning Geneva: Transnational Aspects of Protest and Resistance in South West Africa/Namibia after the First World War'. Journal of Southern African Studies 35 (2009): 785.

Dembour, Marie-Bénédicte. Who Believes in Human Rights? Reflections on the European Convention. Cambridge University Press, 2006. 
De Schutter, Olivier. International Human Rights Law. Cases, Materials, Commentary. Cambridge: Cambridge University Press, 2010.

Despagnet, Frantz. Cours de Droit International Public. Paris: L. Larose, 1894.

Dimier, Veronique. 'On Good Colonial Government: Lessons from the League of Nations'. Global Society 18 (2004): 279.

Dinstein, Yoram. 'Collective Human Rights of Peoples and Minorities'. The International and Comparative Law Quarterly 25 (1976): 102.

Dodge, Toby. 'International Obligation, Domestic Pressure and Colonial Nationalism; the Birth of the Iraqi State Under the Mandate System'. In The British and French Mandates in Comparative Perspectives/Les Mandats Français et Anglais Dans Une Perspective Comparative, edited by Nadine Meouchy and Peter Sluglett. Leiden: Brill Academic Publishers, 2004.

Donelly, Jack. 'Human Rights: A New Standard of Civilization?' International Affairs 74 (1998): 1.

Drescher, Seymour. 'From Consensus to Consensus: Slavery in International Law'. In The Legal Understanding of Slavery. From the Historical to the Contemporary, edited by Jean Allain, 85. Oxford: Oxford University Press, 2012.

Dugard, John. '1966 and All That. The South West Adrican Judgment Revisited in the East Timor Case'. African Journal of International and Comparative Law 8 (1996): 549.

- - - . 'Namibia (South West Africa): The Court's Opinion, South Africa's Response, and Prospects for the Future'. Columbia Journal of Transnational Law 11 (1972): 14.

- - - . 'The Revocation of the Mandate for South West Africa'. American Journal of International Law 62 (1968): 78.

_ _ _. 'The South West Africa Cases, Second Phase, 1966.' South African Law Journal 83 (1966): 429.

Eckel, Jan. 'Human Rights and Decolonization: New Perspectives and Open Questions'. Humanity: An International Journal of Human Rights, Humanitarianism, and Development 1 (2010): 111.

Eckert, Andreas. 'Slavery in Colonial Cameroon, 1880s to 1930s'. Slavery e' Abolition: A Journal of Slave and Post-Slave Studies 19 (1998): 133.

Egerton, George W. 'The Lloyd George Government and the Creation of the League of Nations'. American Historical Review 79 (1974): 419.

Eide, Asbjørn. 'Economic, Social and Cultural Rights as Human Rights'. In Economic, Social and Cultural Rights, edited by Asbjørn Eide, Catarina Krause, and Allan Rosas. Dordrecht: Martinus Nijhoff Publishers, 2001.

Evans, Carolyn. Freedom of Religion Under the European Convention on Human Rights. Oxford University Press, 2001.

Evans, Malcolm D. Religious Liberty and International Law in Europe. Cambridge: Cambridge University Press, 1997.

Falk, Richard A. Reviving the World Court. Charlottesville, VA: University of Virginia Press, 1986.

- - - 'The South West Africa Cases: An Appraisal'. International Organization 21 (1967): 1.

- - - 'The South West Africa Cases: The Limits of Adjudication, in Ethiopia and Liberia vs. South Africa: The South West Africa Cases'. In UCLA African Studies Center, Occasional Paper No. 5, 1968.

Fenwick, Charles G. International Law. New York \& London: The Century co., 1924.

Fieldhouse, D. K. Western Imperialism in the Middle East 1914-1958. Oxford: Oxford University Press, 2006.

Fink, Carole. 'The League of Nations and the Minorities Question.' World Affaird 157 (1995): 197.

Fisch, Jörg. 'Africa as Res Nullius: The Berlin Conference and International Law'. In Bismarck, Europe, and Africa: The Berlin Africa Conference 1884-1885 and the Onset of Partition, edited by Stig Förster, Wolfgang Justin Mommsen, and Ronald Edward Robinson. London: Oxford University Press, 1988. 
Friedmann, Wolfgang G. 'The Jurisprudential Implications of the South West Africa Case'. Columbia Journal of Transnational Law 6 (1967): 1.

Gathii, James Thuo. 'International Law and Eurocentricity'. European Journal of International Law 9 (1998): 184.

Gearty, Conor. 'Afterword'. In Revisiting the Origins of Human Rights, edited by Miia HalmeTuomisaari and Pamela Slotte, 381. Cambridge: Cambridge University Press, 2015.

Gerig, Benjamin. The Open Door and the Mandates System, London: George Allen \& Unwin, 1930.

Gong, Gerrit. The Standard of 'Civilization' in International Society. Oxford: Clarendon Press, 1984.

Goodrich, Leland M. 'From League of Nations to United Nations'. International Organization 1 (1947): 3.

Goodridge, Richard A. 'The Issue of Slavery in the Establishment of British Rule in Northern Cameroun to 1927'. African Economic History 22 (1994): 19.

Grant, Kevin. 'The British Empire, International Government, and Human Rights'. History Compass 11 (2013): 573.

Grewe, Wilhelm G. The Epochs of International Law. Berlin: de Gruyter, 2000.

Gross, Ernest A. 'The South West Africa Case: What Happened?' Foreign Affairs 45 (1966): 36.

Haas, Ernst. 'The Reconciliation of Conflicting Colonial Policy Aims (mandates)', International Organization 6 (1952) 521.

Hales, James C. 'Some Legal Aspects of the Mandate System: Sovereignty - Nationality Termination and Transfer'. Transactions of the Grotius Society 23 (1937): 85.

- - - . 'The Creation and Application of the Mandate System. (A Study in International Colonial Supervision)'. Transactions of the Grotius Society 25 (1939): 185.

Hall, H. Duncan. Mandates, Dependencies and Trusteeship. London: Stevens \& Sons Limited, 1948.

Halme-Tuomisaari, Miia, and Pamela Slotte. 'Revisiting the Origins of Human Rights: Introduction'. In Revisiting the Origins of Human Rights, edited by Miia HalmeTuomisaari and Pamela Slotte. Cambridge: Cambridge University Press, 2015.

Harris Evans, Luther. 'The General Principles Governing the Termination of the Mandate'. The American Journal of International Law 26 (1932): 735.

Hevener, Natalie K. 'International Law and the Status of Women: An Analysis of International Legal Instruments Related to the Treatment of Women'. Harvard Women's Law Journal 1 (1978): 131.

- _ . 'The 1971 South-West African Opinion'. International and Comparative Law Quarterly 24 (1975): 791.

Hickford, Mark. Lords of the Land: Indigenous Property Rights and the Jurisprudence of Empire. Oxford: Oxford University Press, 2011.

Higgins, Rosalyn. 'Human Rights in the International Court of Justice'. Leiden Journal of International Law 20 (2007): 745.

- - - 'The International Court and South West Africa. The Implications of the Judgement.' International Affairs 42 (1966): 573.

Highet, Keith. 'The South West Africa Cases'. Current History 52 (1967): 154.

Hilderbrand, Robert C. Dumbarton Oaks: The Origins of the United Nations es the Search for Postwar Security. Chapel Hill [N.C.]: University of North Carolina Press, 1990.

Hoffmann, Stefan-Ludwig. 'Introduction. Genealogies of Human Rights'. In Human Rights in the Twentieth Century, edited by Stefan-Ludwig Hoffmann, 1-26. Cambridge: Cambridge University Press, 2011.

Hornung, Joseph. 'Civilisés et Barbares'. Revue de Droit International et de Législation Comparée XVIII (1886) 188.

Hudson, Manley O. 'The League of Nations and the Protection of the Inhabitants of Transferred Territories'. The Annals of the American Academy 96 (1921): 78.

Hunt, Lynn. Inventing Human Rights. London, New York: W. W. Norton, 2007. 
Ishay, Micheline R. The History of Human Rights from Ancient Times Ot the Globalization Era. Second edition. Berkeley \& Los Angeles: University of California Press, 2008.

Jensen, Steven L. B. The Making of International Human Rights. The 1960d, Decolonization, and the Reconstruction of Global Values. Cambridge: Cambridge University Press, 2016.

Kapur, Ratna. "The Tragedy of Victimization Rhetoric: Resurrecting the "Native" Subject in International/Post-Colonial Feminist Legal Politics'. Harvard Human Rights Journal 15 (2002): 1.

Karlsson, Andrea, and Linde Lindkvist. 'Triumf, Tröstpris Eller öppen Praktik? De Mänskliga Rättigheternas Historia.' Historisk Tidskrift 132 (2012): 92.

Kattan, Victor. 'Decolonizing the International Court of Justice: The Experience of Judge Sir Muhammad Zafrulla Khan in the South West Africa Cases'. Asian Journal of International Law 5 (2015): 310.

Kawamura, Noriko. 'Wilsonian Idealism and Japanese Claims at the Paris Peace Conference.' Pacific Historical Review 66 (1997): 503.

Kennedy, David. 'The Move to Institutions', Cardozo Law Revue 8 (1987): 841.

Klabbers, Jan, The Concept of Treaty in International Law. The Hague: Kluwer Law International (1996)

- - - . 'Right to Be Taken Seriously: Self-Determination in International Law, The'. Human Rights Quarterly 28 (2006): 186.

Kluyver, C. A., ed. Documents on the League of Nations. Leiden: A W. Sijthoff's Uitgeversmaatschappij, 1920.

Knock, Thomas J. To End All Wars: Woodrow Wilson and the Quest for a New World Order. Princeton, NJ: Princeton University Press, 1995.

Knoll, Bernhard. The Legal Status of Territories Subject to Administration by International Organisations. Cambridge : Cambridge University Press, 2008.

Knop, Karen. Diversity and Self-Determination in International Law. Cambridge: Cambridge University Press, 2002.

Koskenniemi, Martti. 'Foreword: History of Human Rights as Political Intervention in the Present'. In Revisiting the Origins of Human Rights, edited by Miia Halme-Tuomisaari and Pamela Slotte, ix. Cambridge: Cambridge University Press, 2015.

- - - . 'International Law in Europe: Between Tradition and Renewal'. European Journal of International Law 16 (2005): 113.

- - - . 'Lauterpacht: The Victorian Tradition in International Law'. European Journal of International Law 2 (1997): 215.

- - - . The Gentle Civilizer of Nations: The Rise and Fall of International Law 1870-1960. Cambridge: Cambridge University Press, 2001.

Landis, Elizabeth S. 'South West Africa Cases Remand to the United Nations'. Cornell Law Review 52 (1966-1967): 627.

Lauren, Paul Gordon. 'Human Rights in History Diplomacy and Racial Equality at the Paris Peace Conference'. Diplomatic History 2 (1978): 257.

- - - . The Evolution of International Human Rights: Visions Seen. Philadelphia: University of Pennsylvania Press, 2003.

Lauterpacht, Hersch. International Law and Human Rights. Hamden, Connecticut: Archon Books, 1968.

- _ - 'The Mandate Under International Law in the Covenant of the League of Nations'. In International Law Being the Collected Papers of Hersch Lauterpacht, Volume 3, edited by Elihu Lauterpacht, 29. Cambridge: Cambridge University Press, 1977.

Lawrence, T. J. (Thomas Joseph). The Principles of International Law. 2nd edition. London: Macmillan and co., 1898.

League of Nations. The Mandates System. Origin, Principles, Application. League of Nations, 1945.

Lee, Christopher J. Making a World After Empire : The Bandung Moment and Its Political Afterlives. Athens OH: Ohio University Press, 2010.

Liszt, Franz von. Das Völkerrecht. Systematisch Dargestellt. Elfte, umgearbeitete Auflage. Berlin: Julius Springer Verlag, 1918. 
Lorimer, James. The Institutes of the Law of Nations: A Treative of the Jural Relations of Separate Political Communities. Edinburgh: William Blackwood and Sons, 1883.

Luard, Evan. A History of the United Nations - Volume 2: The Age of Decolonization. London: Macmillan, 1989.

Lugard, Frederick. The Dual Mandate in British Tropical Africa. Edinburgh and London: William Blackwood and Sons, 1922.

Makowski, Julien. 'La Nature Juridique Des Mandats B et C'. Revue Générale de Droit International Public, 40 (1933): 374.

Mamdani, Mahmood. Citizen and Subject. Contemporary Africa and the Legacy of Late Colonialism. Princeton, New Jersey: Princeton University Press, 1996.

Martinez, Jenny S. 'Human Rights and History'. Harvard Law Review Forum 126 (2012): 221.

- - - . The Slave Trade and the Origins of International Human Rights Law. New York: Oxford University Press, 2012.

Martitz, Ferdinand von. Kansainsälinen Oikeus. Helsinki: SKS, 1914.

Maul, Daniel Roger. 'The International Labour Organization and the Struggle against Forced Labour from 1919 to the Present'. Labor History 48 (2007): 477.

Mazower, Mark. 'An International Civilization? Empire, Internationalism and the Crisis of the Mid-Twentieth Century'. International Affairs 82 (2006): 553.

- - - . No Enchanted Palace: The End of Empire and the Ideological Origins of the United Nations. Princeton: Princeton University Press, 2009.

- _ - 'The Strange Triumph of Human Rights, 1933-1950'. The Historical Journal 47 (2004): 379.

McWhinney, Edward. 'The Changing United Nations Constitutionalism. New Arenas and New Techniques for International Law-Making'. The Canadian Yearbook of International Law 5 (1967): 73.

Merrills, John Graham. Judge Sir Gerald Fitzmaurice and the Discipline of International Law: Opinions on the International Court of Justice, 1961-1973. Leiden: Martinus Nijhoff Publishers, 1998.

Metzger, Barbara. 'Towards an International Human Rights Regime during the Inter/War Years: The League of Nations' Combat of Traffic in Women and Children'. In Beyond Sovereignty: Britain, Empire and Transnationalism, C. 1880-1950, edited by Kevin Grant, Philippa Levine, and Frank Trentmann, 54. London: Basingstoke, 2007.

Miers, Suzanne. 'Slavery and the Slave Trade as International Issues 1890-1939'. Slavery e' Abolition: A Journal of Slave and Post-Slave Studies 19 (1998): 16.

- - - . Slavery in the Twentieth Century: The Evolution of a Global Problem. Walnut Creek, CA.: Rowman Altamira, 2003.

Miller, Carol. "Geneva - the Key to Equality": Inter-War Feminists and the League of Nations'. Women's History Review 3, (2006): 219.

Miller, David Hunter. Drafting of the Covenant. Vol. 1. New York: G. P. Putnam's Sons, 1928.

- - - Drafting the Covenant. Vol. 2. New York: G. P. Putnam's Sons, 1928.

Millot, Albert. Les Mandats Internationaux; étude Sur L'application de L'article 22 Du Pacte de La Société Des Nations. Paris: E. Larose, 1924.

Mohney, Seth. 'The Great Power Origins of Human Rights'. Michigan Journal of International Law 35 (2014): 827.

Momirov, Aleksandar. 'The Individual Right to Petition in Internationalized Territories. From Progressive Thought to an Abandoned Practice.' Journal of the History of International Law 9 (2007): 203.

Moncharville, M. 'L'execution Du Mandat Français Au Togo et Au Cameroun'. Revue Générale de Droit International Public 32 (1925): 58.

Moyn, Samuel. 'Substance, Scale, and Salience: The Recent Historiography of Human Rights'. Annual Review of Law and Social Science 8 (2012): 123.

- - - . The Last Utopia. Human Rights in History. Cambridge, MA: Harvard University Press, 2010. 
Murray, James N. The United Nations Trusteeship System. The University of Illinois Press, 1957.

Northedge, F. S. The League of Nations: Its Life and Times 1920-1946. New York: Leicester University Press, 1988.

Nowak, Manfred. Introduction to the International Human Rights Regime. Leiden: Brill Academic Publishers, 2003.

Nuzzo, Luigi. 'Colonial Law'. European History Online (EGO), Publisbed by the Leibniz Institute of European History, 2012. http://www.ieg-ego.eu/nuzzol-2011-en. Accessed November 14, 2016.

Oppenheim, Lassa. International Law. A Treatise. Vol. I - Peace. 3rd edition. London: Longmans, Green and Co., 1920.

Orford, Anne. 'In Praise of Description'. Leiden Journal of International Law 25 (2012): 609.

- - _. 'The Past as Law or History? The Relevance of Imperialism for Modern International Law'. SSRN Scholarly Paper. Rochester, NY: Social Science Research Network, 9 September 2011. http://papers.ssrn.com/abstract=2090434. Accessed November 14, 2016.

Palacios, Leopoldo. Los mandatos internacionales de la Sociedad de Naciones. Madrid: Minuesa de los Rios, 1927

Pedersen, Susan. 'Did "Imperial Trusteeship" Have Anything to Do with "Human Rights"?', unpublished paper, on file with the author, 2011.

- - - . 'Metaphors of the Schoolroom: Women Working the Mandates System of the League of Nations'. History Workshop Journal 66 (2008): 188.

- - - . 'Samoa on the World Stage: Petitions and Peoples before the Mandates Commission of the League of Nations.' Journal of Imperial and Commonwealth History 40 (2012): 231.

- - - The Guardians: The League of Nations and the Crisis of Empire. 1 edition. Oxford: Oxford University Press, 2015.

- - - . 'The Meaning of the Mandates System: An Argument'. Geschichte Und Gesellschaft 32 (2006): 560.

Peter, Ania. William E. Rappard Und Der Volkerbund. Bern: Peter Lang, 1973.

Peters, Pauline E. 'Challenges in Land Tenure and Land Reform in Africa'. World Development 37 (2009): 1317.

Petman, Jarna. Human Rights and Violence. The Hope and Fear of the Liberal World. Oxford: Hart Publishing, forthcoming.

Pliley, Jessica R. 'Claims to Protection: The Rise and Fall of Feminist Abolitionism in the League of Nations' Committee on the Traffic in Women and Children, 1919-1936'. Journal of Women's History 22 (2010): 90.

Pollock, Alexander. 'The South West Africa Cases and the Jurisprudence of International Law'. International Organization 23 (1969): 767.

Pomerance, Michla. 'Case Analysis: The ICJ and South West Africa (Namibia): A Retrospective Legal/Political Assessment'. Leiden Journal of International Law 12 (1999): 425.

- - - . The Advisory Function of the International Court in the League and UN Eras. Baltimore: Johns Hopkins University Press, 1973.

Pool, David. 'From Elite to Class: The Transformation of Iraqi Leadership, 1920-1939'. International Journal of Middle East Studies 12 (1980): 331.

Potter, Pitman. 'The Origin of the System of Mandates: Further Notes'. The American Political Science Review 20 (1926): 842.

Rajagopal, Balakrishnan. International Law from Below: Development, Social Movements and Third World Resistance. Cambridge: Cambridge University Press, 2003.

Ramusack, Barbara N. 'Cultural Missionaries, Maternal Imperialists, Feminist Allies. British Women Activists in India, 1865-1945'. In Western Women and Imperialism: Complicity and Resistance, edited by Nupur Chaudhuri and Margaret Strobel. Bloomington: Indiana University Press, 1992. 
Rappard, William. International Relations as Viewed from Geneva. New Haven: Yale University Press, 1925.

- - - . 'Nationalism and the League of Nations Today'. The American Political Science Review 27 (1933): 721.

- - - . 'Human Rights in Mandated Territories'. The Annals of the American Academy of Political and Social Science 243 (1946): 118.

- - - . 'Mandates and Trusteeships: With Particular Reference to Palestine'. The Journal of Politico 8 (1946): 520.

- - - . 'Mandates Under the League of Nations. Book Review.' The American Political Science Review 24 (1930): 1026.

_ - _. 'The Evolution of the League of Nations'. The American Political Science Review 21 (1927): 792.

- _ - . 'The Mandates and the International Trusteeship Systems'. Political Science Quarterly 61 (1946): 408-19.

Redman, Renee Colette. 'The League of Nations and the Right to Be Free from Enslavement: The First Human Right to Be Recognized as Customary International Law'. Chicago-Kent Law Review 70 (1994): 759.

Rees, D. F. W. van. 'Les Mandats Internationaux', In Bibliotheca Visseriana Dissertationum Ius Internationale Illustrantium, Lugduni Batavorum: Apud E. J. Brill, 1931.

Reisman, W. Michael. 'Revision of the South West Africa Cases'. Faculty Scholarship Series, 1 January 1966. http://digitalcommons.law.yale.edu/fss_papers/676. http://papers.ssrn.com/abstract=2090434.

Reus-Smit, Christian. Individual Rights and the Making of the International System. Cambridge: Cambridge University Press, 2013.

Richter, Roland. 'Land Law in Tanganyika since the British Military Occupation and under the British Mandate of the League of Nations'. In Land Law and Land Ownership in Africa. Case Studies from Colonial and Contemporary Cameroon and Tanzania, edited by Robert Debusmann. Bayreuth: Bayreuth University, 1996.

Riedi, Eliza. 'Women, Gender, and the Promotion of Empire: The Victoria League, 19011914'. The Historical Journal 45 (2002): 569.

Rodley, Nigel S. 'Human Rights and Humanitarian Intervention: The Case Law of the World Court'. International o' Comparative Law Quarterly 38(1989): 321.

Sayre, Francis B. 'Legal Problems Arising from the United Nations Trusteeship System'. American Journal of International Law 42 (1948): 263.

Schnee, Heinrich. Deutschland Braucht Kolonien? Ein Vortrag. Leipzig: Quelle \& Meyer, 1921.

Schücking, Walther, and Hans Wehberg. Die Satzung Des Völkerbundes. Zweite umgearbeitete Auflage. Berlin: Verlag von Franz Vahlen, 1924.

Schwelb, Egon. 'The International Court of Justice and the Human Rights Clauses of the Charter'. American Journal of International Law 66 (1972): 337.

Shaw, Malcolm. International Law. 6th edition. Cambridge: Cambridge University Press, 2008.

Simma, Bruno. 'Mainstreaming Human Rights: The Contribution of the International Court of Justice'. Journal of International Dispute Settlement 3 (2012): 7.

Simma, Bruno et al. The Charter of the United Nations. A Commentary. Oxford: Oxford University Press, 2012.

Simpson, A. W. Brian. Human Rights and the End of Empire: Britain and the Genesis of the European Convention. Oxford: Oxford University Press, 2001.

Simpson, Gerry. Great Powers and Outlaw States: Unequal Sovereigns in the International Legal Order. Cambridge: Cambridge University Press, 2004.

Sluglett, Peter. 'The Mandate System: High Ideals, Illiberal Practices'. In Liberal Thought in the Eastern Mediterranean: Late 19th Century Until the 1960s, edited by Christoph Schumann, 29-49. Leiden: Brill Academic Publishers, 2008.

Smith, Rhona K. M. Textbook on International Human Rights. 3rd edition. Oxford: Oxford University Press, 2007. 
Smuts, Jan Christiaan. The League of Nations: A Practical Suggestion. London: Hodder and Stoughton, 1918.

Stearns, Peter N. Human Rights in World History. Abingdon, Oxon: Routledge, 2012.

Stone, J. 'Reflections on Apartheid After the South West Africa Cases'. Wasbington Law Review 42 (1967): 1069.

$\mathrm{Su}$, Anna. 'Woodrow Wilson and the Origins of the International Law of Religious Freedom'. Journal of the History of International Law 15 (2013): 235.

Tams, Christian J. 'Re-Introducing Walther Schücking'. European Journal of International Law 22 (2011): 725.

Taylor, Paul M. Freedom of Religion: UN and European Human Rights Law and Practice. Cambridge: Cambridge University Press, 2006.

Terretta, Meredith. "We Had Been Fooled into Thinking That the UN Watches over the Entire World": Human Rights, UN Trust Territories, and Africa's Decolonization'. Human Rights Quarterly 34 (2012): 329.

Tomuschat, Christian. Human Rights. Between Idealism and Realism. Oxford: Oxford University Press, 2003.

Toussaint, Charmian Edwards. The Trusteeship System of the United Nations. New York: Frederick A. Praeger Inc., 1956.

Villiger, Mark. Commentary on the 1969 Vienna Convention on the Law of Treaties. Leiden: Martinus Nijhoff Publishers, 2009.

Walters, Francis P. A History of the League of Nations. London: Oxford University Press, 1969.

Westlake, John. International Law, Part 1, Peace. Cambridge: Cambridge University Press, 1910.

Wheatley, Natasha. 'Mandatory Interpretation: Legal Hermeneutics and the New International Order in Arab and Jewish Petitions to the League of Nations'. Past o’ Present 227 (2015): 205.

Wheaton, Henry. Elements of International Law. 8th edition. London: Sampson Low, Son, and Company, 1866.

Wilde, Ralph. International Territorial Administration: How Trusteeship and the Civilizing Mission Never Went Away. Oxford: Oxford University Press, 2008.

Wortley, B. A. 'Idealism in International Law: A Spanish View of the Colonial Problem'. Transactions of the Grotius Society 24 (1938): 147.

Wright, Quincy. Human Rights and the World Order. New York, N. Y.: Commission to study the organization of peace, 1943.

- _ - Mandates Under the League of Nations. New York: Greenwood Press, 1968.

- - - . 'The Proposed Termination of the Iraq Mandate'. The American Journal of International Law 25 (1931): 436.

Zimmermann, Andreas et al. (eds.) The Statute of the International Court of Justice. A Commentary. 2nd edition. Oxford: Oxford University Press, 2012.

Zyberi, Gentian. 'Self-Determination through the Lens of the International Court of Justice'. Netherlands International Law Review LVI (2009): 429-53.

\section{International Treaties}

Final Act of the Berlin Conference, February 26, 1885.

The Versailles Treaty, June 28, 1919.

The Covenant of the League of Nations, Part I of the Versailles Treaty, June 28, 1919.

International Convention for the Suppression of the Traffic in Women and Children, September 30, 1921.

Slavery Convention, September 25, 1926. 
Convention concerning Forced or Compulsory Labour, June 28, 1930.

Charter of the United Nations, June 26, 1945.

European Convention on Human Rights, November 4, 1950.

Vienna Convention on the Law of Treaties, May 23, 1969.

International Covenant on Civil and Political Rights, December 19, 1966.

\section{League of Nations Documents}

Obligations Falling Upon the League of Nations Under the Term of Article 22 of the Covenant (Mandates). Report presented by the Belgian Representative, M. Hymans, and adopted by the Council of the League of Nations, 1 League of Nations Official Journal (1920), 334.

Report on the State of Palestine Presented, to the Right Honourable Mr. Winston Churchill, P.C., M.P., by the Executive Committee of the Arab Palestine Congress, 2 League of Nations Official Journal (1921), 331-340

Letter from the Acting President of the Council of the League of Nations to the Principal Allied Powers 2 League of Nations Official Journal (1921), 441-442.

Memorial to the League of Nations by the "Native Races and the Liquor Traffic United Committee", 2 League of Nations Official Journal (October 1921), 823-824.

Twenty-first Session of the Council, Petitions from the Inhabitants of the Mandated Territories, 3 League of Nations Official Journal (1922), 1176.

Twenty-third Session of the Council, Petitions regarding inhabitants of the Mandated Territories, 4 League of Nations Official Journal (1923), 200.

Procedure in Respect of Petitions Regarding Inhabitants of Mandated Territories. Report by M. Calandra and resolutions adopted by the Council on January 31st, 1923, 4 League of Nations Official Journal (1923), 298.

Permanent Mandates Commission. Report on the Work of the Third Session of the Commission, submitted to the Council of the League of Nations on August 31st, 1923. 4 League of Nations Official Journal (1923), 1380.

\section{Minutes of the Permanent Mandates Commission}

Permanent Mandates Commission, Minutes of the First Session, 1921.

Permanent Mandates Commission, Minutes of the Second Session, 1922.

Permanent Mandates Commission, Minutes of the Third Session, 1923.

Permanent Mandates Commission, Minutes of the Fourth Session, 1925.

Permanent Mandates Commission, Minutes of the Fifth Session, 1924.

Permanent Mandates Commission, Minutes of the Sixth Session, 1925.

Permanent Mandates Commission, Minutes of the Seventh Session, 1925.

Permanent Mandates Commission, Minutes of the Eighth Session, 1926 (extraordinary).

Permanent Mandates Commission, Minutes of the Ninth Session, 1926.

Permanent Mandates Commission, Minutes of the Tenth Session, 1926.

Permanent Mandates Commission, Minutes of the Eleventh Session, 1927. 
Permanent Mandates Commission, Minutes of the Twelfth Session, 1927.

Permanent Mandates Commission, Minutes of the Thirteenth Session, 1928.

Permanent Mandates Commission, Minutes of the Fourteenth Session, 1928.

Permanent Mandates Commission, Minutes of the Fifteenth Session, 1929.

Permanent Mandates Commission, Minutes of the Sixteenth Session, 1929.

Permanent Mandates Commission, Minutes of the Seventeenth Session, 1930 (extraordinary).

Permanent Mandates Commission, Minutes of the Eighteenth Session, 1930.

Permanent Mandates Commission, Minutes of the Nineteenth Session, 1930.

Permanent Mandates Commission, Minutes of the Twentieth Session, 1931.

Permanent Mandates Commission, Minutes of the Twenty-first Session, 1931.

Permanent Mandates Commission, Minutes of the Twenty-second Session, 1932.

Permanent Mandates Commission, Minutes of the Twenty-third Session, 1933.

Permanent Mandates Commission, Minutes of the Twenty-fourth Session, 1933.

Permanent Mandates Commission, Minutes of the Twenty-fifth Session, 1934.

Permanent Mandates Commission, Minutes of the Twenty-sixth Session, 1934.

Permanent Mandates Commission, Minutes of the Twenty-seventh Session, 1935.

Permanent Mandates Commission, Minutes of the Twenty-eighth Session, 1935.

Permanent Mandates Commission, Minutes of the Twenty-ninth Session, 1936.

Permanent Mandates Commission, Minutes of the Thirtieth Session, 1936.

Permanent Mandates Commission, Minutes of the Thirty-first Session, 1937.

Permanent Mandates Commission, Minutes of the Thirty-second Session, 1937 (extraordinary).

Permanent Mandates Commission, Minutes of the Thirty-third Session, 1937.

Permanent Mandates Commission, Minutes of the Thirty-fourth Session, 1938.

Permanent Mandates Commission, Minutes of the Thirty-fifth Session, 1938.

Permanent Mandates Commission, Minutes of the Thirty-sixth Session, 1939.

Permanent Mandates Commission, Minutes of the Thirty-seventh Session, 1939.

\section{A Mandates}

Balfour Declaration, November 2, 1917

Treaty Between Great Britain and Iraq, 3 League of Nations Official Journal (1922), 1505.

British Mandate for Palestine, 17 The American Journal of International Law, Supplement: Official Documents (1923), 164.

French Mandate for Syria and Lebanon, 17 The American Journal of International Law, Supplement: Official Documents (1923), 177.

The Organic Law of Iraq, 5 League of Nations Official Journal (1924), 1761.

Franco-Syrian Treaty of Independence, September 9, 1936

\section{B Mandates}

British Mandate of Cameroons, 17 The American Journal of International Law, Supplement: Official Documents (1923), 138. 
French Mandate of Cameroons, 17 The American Journal of International Law, Supplement: Official Documents (1923), 145.

Belgian Mandate for East Africa, 17 The American Journal of International Law, Supplement:

Official Documents (1923), 149.

British Mandate for East Africa, 17 The American Journal of International Law, Supplement:

Official Documents (1923), 153.

British Mandate of Togoland, 17 The American Journal of International Law, Supplement:

Official Documents (1923), 182.

French Mandate of Togoland, 17 The American Journal of International Law, Supplement:

Official Documents (1923), 190.

\section{Mandates}

Mandate for the Former German Possessions in the Pacific Ocean Situated South of the Equator, Other than German Samoa and Nauru, 17 The American Journal of International Law, Supplement: Official Documents (1923), 158.

Mandate for the Former German Possessions in the Pacific Ocean Lying North of the Equator, 17 The American Journal of International Law, Supplement: Official Documents (1923), 160.

Mandate for Nauru, 17 The American Journal of International Law, Supplement: Official Documents (1923), 162.

Mandate for German Samoa, 17 The American Journal of International Law, Supplement: Official Documents (1923), 173.

Mandate for German South-West Africa, 17 The American Journal of International Law, Supplement: Official Documents (1923), 175.

\section{Proceedings of International Meetings}

Atlantic Charter, August 14, 1941.

Washington Conversations on International Peace and Security Organization, Dumbarton Oaks, October 7, 1944.

Protocol of Proceedings of the Crimea Conference, signed by Joseph Stalin, Franklin D. Roosevelt and Winston Churchill, February 11, 1945.

Final Communiqué of the Asian-African Conference of Bandung, April 24, 1955. 


\section{Case Law of the International Court of Justice}

Corfu Channel case (United Kingdom of Great Britain and Northern Ireland v. Albania), Judgment of 9 April, 1949: I.C.J. Reports 1949, 4.

International Status of South West Africa, Advisory Opinion of July 11, 1950: I.C.J. Reports 1950, 128.

South-West Africa - Voting Procedure, Advisory Opinion of 7 June, 1955: I.C.J. Reports $1955,67$.

Admissibility of Hearings of Petitioners by the Committee on South West Africa, Advisory Opinion of 1 June, 1956: I.C.J. Reports 1956, 23

South West Africa Cases (Ethiopia v. South Africa; Liberia v. South Africa), Preliminary Objections, Judgment of 21 December, 1962: I.C.J. Reports, 1962, 319.

Case concerning the Northern Cameroons (Cameroon $v$. United Kingdom), Preliminary Objections, Judgment of 2 December, 1963: I.C.J. Reports 1963, 15.

South West Africa Cases (Ethiopia v. South Africa; Liberia v. South Africa), Second Phase, Judgment of 18 July 1966: I.C.J. Reports 1966, 6.

Legal Consequences for States of the Continued Presence of South Africa in Namibia (South West Africa) notwithstanding Security Council Resolution 276 (1970), Advisory Opinion of June 21, 1971: I.C.J. Reports 1971, 16.

Certain Phosphate Lands in Nauru (Nauru $v$. Australia). Preliminary Objections, Judgment of June 26, 1992: I.C.J. Reports 1992, 240;

Legal Consequences of the Construction of a Wall in the Occupied Palestinian Territory, Advisory Opinion of July 9, 2004: I.C.J. Reports 2004, 136

Accordance with International Law of the Unilateral Declaration of Independence in Respect of Kosovo, Advisory Opinion of July 22, 2010: I.C.J. Reports 2010, 403.

\section{Other Case Law}

District Governor, Jerusalem-Jaffa District and Another v. Suleiman Murra and Another. Supreme Court of Palestine. 25 June, 1925. Judicial Committee of the British Privy Council. 16 February, 1926. 3 ILR (1925-1926) 46-47.

Attorney-General v. Abraham Altshuler. Palestine Supreme Court, May 1928. 4 ILR (19271928) 55-56.

Succession of Rizcallah Gazalé Case. Court of Appeal of Aleppo, Syria, 7 May, 1928. 4 ILR (1927-1928) 95-96.

Brown v. Board of Education of Topeka, 347 U.S. 483 (1954). 


\section{United Nations General Assembly and Security Council Resolutions}

General Assembly Resolution 141 (II) of 1 November, 1947.

General Assembly Resolution 217 A (III), 10 December, 1948.

General Assembly Resolution 395 (V) of 2 December, 1950.

General Assembly Resolution 820 (IX) of 14 December, 1954.

General Assembly Resolution 1178 (XII) of 26 November, 1957.

General Assembly Resolution 2145 (XXI) of 27 October, 1966.

Security Council Resolution 134 (1960) of 1 April, 1960.

Security Council Resolution 245 (1968) of January 25, 1968.

Security Council Resolution 246 (1968) of March 14, 1968.

Security Council Resolution 269 (1969) of August 12, 1969

Security Council Resolution 276 (1970) of January 30, 1970.

\section{Websites}

http://www.un.org/en/sections/member-states/growth-united-nations-membership-1945present/index.html. Accessed May 13, 2016. 